Since December 2017

FORESIGHT

AND STI GOVERNANCE

has been included into the database
WEB OF SCIENCE ${ }^{\mathrm{T}}$ CORE COLLECTION EMERGING SOURCES

CITATION INDEX
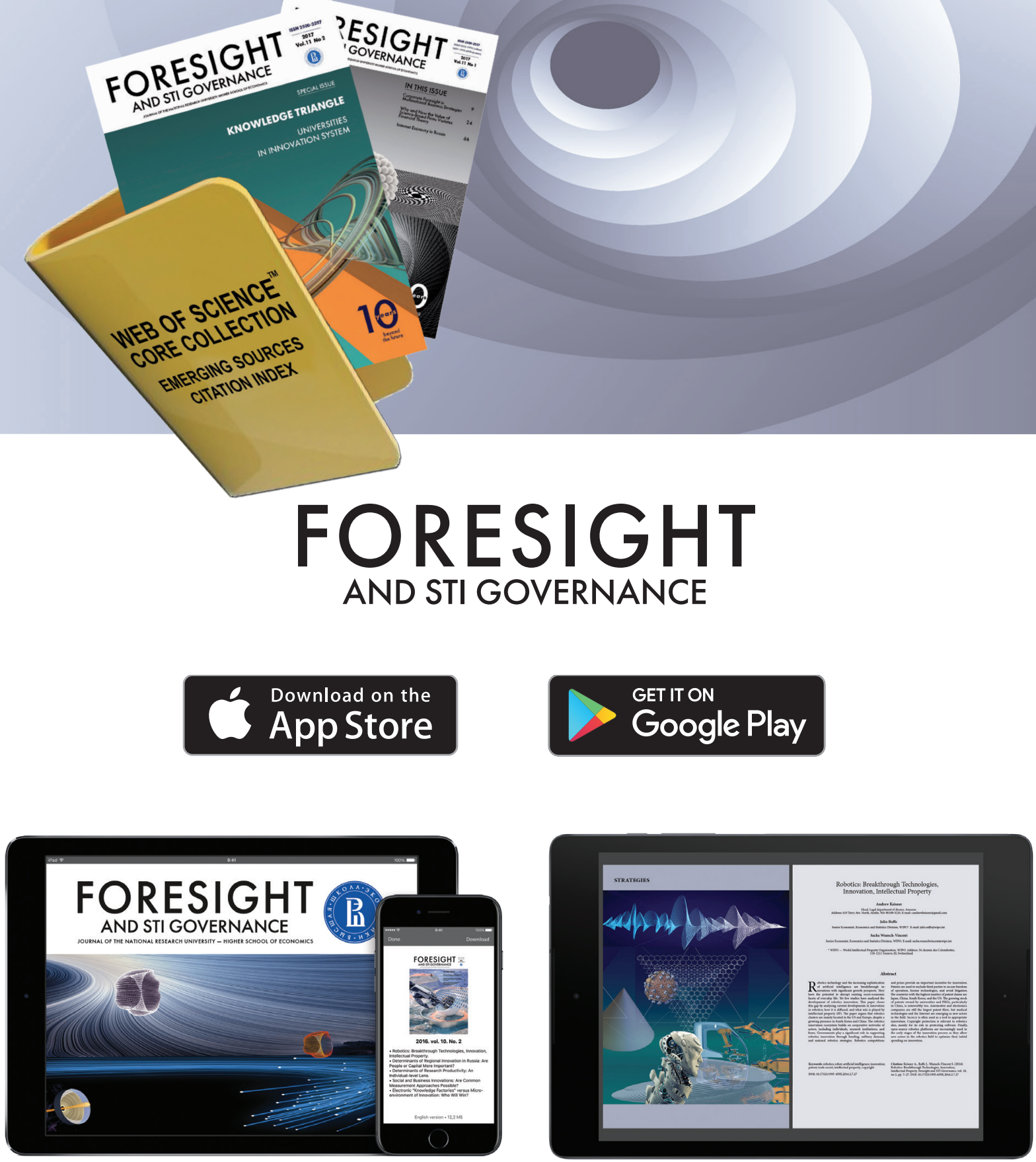


\section{FORESIGHT AND STI GOVERNANCE}

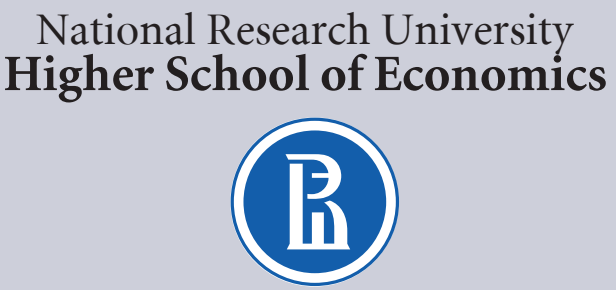

Institute for Statistical Studies
and Economics of Knowledge

Editor-in-Chief — Leonid Gokhberg, First Vice-Rector, HSE, and Director, ISSEK, HSE, Russian Federation

Deputy Editor-in-Chief - Alexander Sokolov, HSE, Russian Federation

\section{EDITORIAL BOARD}

Tatiana Kuznetsova, HSE, Russian Federation

Dirk Meissner, HSE, Russian Federation

Yury Simachev, HSE, Russian Federation

Thomas Thurner, HSE, Russian Federation, and

University of Cape Town, South Africa

Executive Editor - Marina Boykova

Development Manager - Nataliya Gavrilicheva

Literary Editors - Yakov Okhonko, Caitlin Montgomery

Proofreaders - Ekaterina Malevannaya,

Designer - Mariya Salzmann

Layout - Mikhail Salazkin

\section{Address:}

National Research University Higher School of Economics 20, Myasnitskaya str., Moscow, 101000, Russia

Tel: +7 (495) 621-40-38

E-mail: foresight-journal@hse.ru

http://foresight-journal.hse.ru/en/

Periodicity - quarterly

ISSN 2500-2597

ISSN 2312-9972 (online)

ISSN 1995-459X (Russian print version)

\section{Publisher:}

National Research University

Higher School of Economics

(c) National Research University

Higher School of Economics, 2017

\section{EDITORIAL COUNCIL}

Igor Agamirzyan, HSE, Russian Federation

Andrey Belousov, Administration of the President of the Russian Federation

Cristiano Cagnin, Center for Strategic Studies and Management (CGEE), Brasil

Elias Carayannis, George Washington University, United States

Mario Cervantes, Directorate for Science, Technology and Industry, OECD

Charles Edquist, Lund University, Sweden

Ted Fuller, University of Lincoln, UK

Luke Georghiou, University of Manchester, United Kingdom

Karel Haegeman, EU Joint Research Centre (JRC)

Attila Havas, Institute of Economics, Hungarian Academy of Sciences

Michael Keenan, Directorate for Science, Technology and Industry, OECD

Alexander Khlunov, Russian Science Foundation

Andrey Klepach, Bank for Development and Foreign Economic Affairs, Russian Federation

Mikhail Kovalchuk, National Research Centre "Kurchatov Institute», Russian Federation

Yaroslav Kuzminov, HSE, Russian Federation

Carol S. Leonard, HSE, Russian Federation, and University of Oxford, United Kingdom

Jonathan Linton, HSE, Russian Federation, and University of Sheffield, United Kingdom

Ian Miles, HSE, Russian Federation, and University of Manchester, United Kingdom

Rongping Mu, Institute of Policy and Management, Chinese Academy of Sciences

Fred Phillips, Yuan Ze University, Taoyuan, Taiwan

Wolfgang Polt, Joanneum Research, Austria

Ozcan Saritas, HSE, Russian Federation, and University of Manchester, United Kingdom

Klaus Schuch, Centre for Social Innovation, Austria

Nicholas Vonortas, HSE, Russian Federation, and George Washington University, United States

Angela Wilkinson, World Energy Council and University of Oxford, United Kingdom 


\title{
CONTENTS
}

\section{Vol. 11 No 42017 \\ LABOUR MARKET IN THE CONTEXT \\ OF TECHNOLOGICAL TRANSFORMATIONS}

6

Sandrine Kergroach

Industry 4.0: New Challenges and Opportunities for the Labour Market

9

Ricardo Seidl da Fonseca

The Future of Employment: Evaluating the Impact of STI Foresight Exercises

23

Dieter Bögenhold, Robert Klinglmair, Florian Kandutsch

Solo Self-Employment, Human Capital and Hybrid Labour in the Gig Economy

33

Sergey Roshchin, Sergey Solntsev, Dmitry Vasilyev

The Recruiting and Job Search Technologies in the Age of Internet

\author{
44 \\ Ali Shamsi
}

Relationship between Knowledge Management and Managerial Skills:

The Role of Creative Thinking

52

Elena Zavyalova, Dmitry Kucherov, Victoria Tsybova

Human Resource Management at Russian Companies — Leaders of the Global Economy

\section{SCIENCE}

63

Annamaria Inzelt, Laszlo Csonka

The Approach of the Business Sector to Responsible Research and Innovation (RRI)

74

Yuri Simachev, Liudmila Zasimova, Timur Kurbanov

Grant Research Support in Russia: What Can We Learn from the Russian Science Foundation's First Grant Competition?

84

Mikhail Kuzyk, Anna Grebenyuk, Evgenia Kakaeva, Evgeniy Manchenko, Vladimir Dovgiy

What Impedes Universities from Creating Dual-Purpose Technologies? 


\title{
Industry 4.0: New Challenges and Opportunities for the Labour Market
}

\author{
Sandrine Kergroach \\ Senior Economist, Centre for Entrepreneurship, SMEs, Local Development and Tourism, Sandrine.Kergroach@oecd.org \\ Organisation for Economic Cooperation and Development, OECD, 2, rue Andre Pascal 75775 Paris Cedex 16, France
}

\begin{abstract}
$\mathrm{T}$ The introductory article to the special issue "Labour Market in the Context of Technological Transformations" presents an overall picture of the latest technological trends altogether referred to as the Fourth Industrial Revolution (Industry 4.0), their impact on the changing structure of the labour market, the demand for

prospective skills, as well as emerging policy challenges. The author concludes that ensuring the resilience, adaptability and efficiency of labour markets are therefore not only a matter of addressing the skills needs of the Next Production Revolution, but also a prerequisite to social stability and cohesion.
\end{abstract}

Keywords: new production revolution; labour market;

Citation: Kergroach S. (2017) Industry 4.0: New Challenges and Opportunities for the Labour Market. Foresight and STI Governance, vol. 11, no 4, pp. 6-8. demand for skills; production automation; social implications DOI: 10.17323/2500-2597.2017.4.6.8

$\mathrm{W}$ e are living on the threshold of the next production revolution. Ongoing transformations in industry and production activities are unprecedented in terms of their scale and impact. Emerging technological developments are likely to bring widespread automation and irreversible shifts in the structure of jobs, raising major challenges on labour markets and for policymakers responsible for promoting the necessary skills and employment.

Labor and technology have long nurtured a close and mutually beneficial relationship [Keynes, 1930]. While technological change has helped improve labour productivity and has been therefore translated at the firm- and macro-levels into economic growth and job creation, new technologies have substituted labour in many industries and occupations, displacing jobs across sectors, regions, or trades. Capitalization effects have benefited the sectors and enterprises in transition, as well as related sectors and partner firms that have captured positive spill-overs through pervasive supply chains. However, at the same time, destructive effects have disproportionately hit industries, territories, and populations that demonstrated a deficit of skills or lag behind the digital transition.

Our world is going through a deep digital transformation. The Internet of Things (IoT), i.e., the connection of all kinds of devices, objects, and sensors via the Internet, is mutating into a gigantic, powerful and hyper-responsive "superorganism" that can monitor, inform, manage operations, and take action in realtime without the active involvement of individuals, furthermore generating an unprecedented volume of data [OECD, 2015a].

Combined with big data analytics and the storage capacity of cloud computing, the IoT can empower new predictive approaches to decision-making, new business models, intelligent systems, and fully autonomous machines [OECD, 2016]. Applications are spreading rapidly with tremendous repercussions to be expected across a large range of sectors. The IoT in particular enables smart manufacturing by providing data and tools for improving factory operations and better managing risk in the supply chain from product logistics to inventory management to machine maintenance. In network industries, IoTenabled smart grids allow for monitoring traffic, emergencies, infrastructure usage, cutting power outages, reducing waste, and implementing smart pricing programs. 
Likewise, artificial intelligence (AI), i.e., the ability of machines and systems to acquire knowledge and carry out cognitive tasks and intelligent behaviors, can empower new kinds of software and robots to learn and operate independently from human decisions and become self-governing agents.

Combined with the advances in mechanical and electrical engineering, AI can expand the capacity of industrial robots to adapt to the physical world and changing working environments with no reprogramming. AI-enabled robots will increasingly be central to logistics and manufacturing as they possess the potential to ensure greater safety, speed, precision, and productivity. Machine learning is also poised to revolutionize a number of services including marketing, finance, entertainment, and medicine. For instance, AI-based algorithms could help anticipate market fluctuations and the automation of health-related tasks, which could increase the autonomous capacity of surgical robots.

3D printing, i.e., additive manufacturing techniques that allow for building products by adding material in layers, is another example of emerging technologies that have a high potential for transforming production processes and supply chains.

Combined with digital technologies, 3D printing will have far-reaching applications in industry by supporting the integration of the product design, manufacturing, and delivery processes. Currently in use to create models or to produce components or replacement parts, 3D printing will become more important as the range of printable materials expand (often plastics, metals, ceramics, and glass for the time being) and the surface detail and quality of the printed products improve, thus meeting the expectations of end-use markets. Companies will then sell designs instead of physical products. Other applications in the medical field include the bioengineering of implants, prostheses, or organs via DNA printers.

Reaping the benefits these emerging technologies could bring will depend, among other challenges, upon the capacity of labour markets to adapt. As a matter of fact, technological change is one of the major factors likely to influence employment markets, the demand and supply of skills, and the structure of occupations.

Advances in machine learning, robotics, and artificial intelligence will inevitably prompt automation, changing labour demand and driving job displacement [Brynjolfsson, McAfee, 2011]. However, automation will no longer be confined to physical or manual tasks, the dirty, dangerous, or dull tasks, but may put at risk many intellectual, cognitive, or analytical white-collar jobs encompassing some routine tasks, starting with transportation, office support, or consumer services. The OECD estimated that $9 \%$ of jobs in OECD countries could be automated and 25\% could change significantly as a result of the automation of 50\%-70\% of the associated tasks [Arntz et al., 2016].

In turn, other kinds of jobs will appear as new products, processes, or new business models take shape. For instance, the digital transition and big data are spurring demand for data specialists and skills for data analysis that exceeds both the current supply and the current capacity of the education and training systems. Although the occupational structure has already evolved in many countries, with job creation polarizing high- and low-skilled occupation groups and job losses concentrated in middle-skilled routine occupations [Goos et al., 2009; Autor, Dorn, 2013], the areas, scope, and scale of the "creative destruction" to come are still unknown.

Against this backdrop of uncertainty and considering the sizeable repercussions the current technological transformations could have on production systems and societies at large, policy makers need evidence and anticipatory intelligence for forecasting the impact of technological change upon work qualifications and work conditions as well as for the design and evaluation of science, technology, and innovation policies (Seidl da Fonseca in this Special Issue).

New jobs may deviate from the standard full-time employment model and take on non-standard forms (i.e., part-time, temporary, on-call, etc.). Emerging technologies make it possible to de-bundle jobs into smaller tasks in support of global and digital production. The servitisation of the economy has furthermore encouraged the fragmentation of employment into smaller units of self-employment. Work has already become more fragmented with an increasing number of workers holding non-standard jobs or operating a non-standard job as a side business to complement income from their regular work (Bögenhold et al. in this Special Issue).

Yet, non-standard jobs are often associated with low quality jobs, lower wages, and lower skills. While a few may find more work flexibility in the "gig" economy, disadvantaged populations are more likely to be trapped in unconventional work arrangements, and be given less opportunities to access training opportunities and a social safety net (OECD, 2015b).

The rise of the digital platform economy is enabling the reorganization of the labour market and work arrangements [Kenney, Zysman, 2016]. The Internet has increasingly become a space for employees and recruiters to meet. Online work mediation platforms have emerged in recent years linking job seekers and freelancers with companies inviting them to bid on a variety of tasks (Roshchin et al. in this Special Issue) 
New jobs will require new competencies and new skillsets. The mix of skills needed to perform in modern societies has become increasingly complex and will keep evolving as technology-enhanced work environments evolve, requiring future generations of workers to develop digital proficiency and lifelong learning capacities at an early age. For the time being, the tasks that are harder to automate involve problem-solving capabilities, intuition, creativity, and persuasion [Frey, Osborne, 2013]. Soft skills such as self-organization, management, teamwork, or communication skills are also likely to grow in importance in the emerging world. The change in educational profiles will call for a renewed education and training policy agenda and new approaches to teachers' training (Shamsi in this Special Issue). Firms will build their human capital around the new skillsets, also implementing organizational changes and adopting new management practices to ensure an efficient use of their intangible assets (Zavyalova et al in this Special Issue).

Overall, the inequalities and social cleavage that may potentially arise from the emerging technological changes are issues of major concern. Inequalities will not only result from job destruction and employment polarization, but also from weaker social mobility and the persisting digital divide. Job polarization is likely to hit the white-collar middle class hard. Social inequity is also likely to worsen across industries, regions, or occupations as the digital divide between those who can and those who cannot keep up with technological change widens. In that respect, labour prospects for women are unclear [OECD, 2017]. While women are historically less represented in scientific and technological fields, digitalization can help bridge the gender gaps on the labour markets. In particular, the digital platform economy could provide opportunities for greater work flexibility and better work-family balance or for lowering cultural barriers and levelling the playing field with men.

Similarly, the potential dismantlement of the $20^{\text {th }}$ century employment model that rose with mass production and links contracted employment with wages and the welfare system is of particular concern. Employment, pension, healthcare, and social welfare systems are closely intertwined, with salary-based taxes accounting for a substantial share of public resources and budgetary sustainability. Ensuring the resilience, adaptability, and efficiency of labour markets is therefore not only a matter of addressing the skills needed for the Next Production Revolution, but also a prerequisite for social stability and cohesion.

The opinions expressed and arguments employed herein are those of the authors and do not necessarily reflect the official views of the OECD or of the governments of its member countries.

\section{References}

Arntz M., Gregory T., Zierahn U. (2016) The Risk of Automation for Jobs in OECD Countries: A Comparative Analysis (OECD Social, Employment and Migration Working Paper no 189), Paris: OECD. Available at: http:// dx.doi.org/10.1787/5jlz9h56dvq7-en, accessed 26.11.2017.

Autor D.H., Dorn D. (2013) The growth of low-skill service jobs and the polarization of the US labour market. The American Economic Review, vol. 103, no 5, pp. 1553-1597. Available at: http://economics.mit.edu/files/1474, accessed 26.11.2017.

Brynjolfsson E., McAfee A. (2011) Race Against the Machine: How the Digital Revolution is Accelerating Innovation, Driving Productivity and Irreversibly Transforming Employment and the Economy, Lexington, MA: Digital Frontier Press.

Frey C.B., Osborne M.A. (2013) The future of employment: How susceptible are jobs to computerisation?, Oxford, UK: University of Oxford.

Goos M., Manning A., Salomons A. (2009) Job polarization in Europe. American Economic Review: Papers \& Proceedings, vol. 99, no 2, pp. 58-63. Available at: http://dx.doi.org/10.1257/aer.99.2.58, accessed 26.11.2017.

Kenney M., Zysman J. (2016) The Rise of the Platform Economy. Issues in Science and Technology, vol. 32, no 3 (Spring 2016). Available at: http://issues.org/32-3/the-rise-of-the-platform-economy, accessed 26.11.2017.

Keynes J.M. (1930) Economic Possibilities for our Grandchildren. Essays in Persuasion, New York: W.W. Norton \& Co., pp. 358-373. Available at: www.econ.yale.edu/smith/econ116a/keynes1.pdf, accessed 26.11.2017.

OECD (2015a) Data-Driven Innovation: Big Data for Growth and Well-Being, Paris: OECD Publishing. Available at: http://dx.doi.org/10.1787/9789264229358-en, accessed 26.11.2017.

OECD (2015b) Non-standard work, job polarisation and inequality. In It Together: Why Less Inequality Benefits All, Paris: OECD, pp. 135-208. Available at: http://dx.doi.org/10.1787/9789264235120-7-en, accessed 26.11.2017.

OECD (2016) Science, Technology and Innovation Outlook 2016, Paris: OECD, Available at: http://dx.doi.org/10.1787/ sti_in_outlook-2016-end, accessed 26.11.2017.

OECD (2017) Going digital: The future of work for women. The Pursuit of Gender Equality: An Uphill Battle, Paris: OECD, pp. 269-282. Available at: http://dx.doi.org/10.1787/9789264281318-26-en, accessed 26.11.2017. 


\title{
The Future of Employment: Evaluating the Impact of STI Foresight Exercises
}

\author{
Ricardo Seidl da Fonseca \\ International Researcher and Advisor, Former Senior Professional Officer of United Nations Industrial \\ Development Organization (UNIDO), r.seidl.fonseca@gmail.com, ricardo@seidldafonseca.at
}

\begin{abstract}
$\mathrm{T}$ The present paper addresses the impact of Science, Technology and Innovation (STI) Foresight and the resulting STI policy thereof on the critical issue of future industry studies, the demand for employment.

The impact evaluation connecting STI Foresight to employment development proposed here brings together and integrates different scientific sectors such as the interdependence between employment and welfare systems; the role and importance of technological change for employment conditions; the prospects of emerging and future technologies impacting employment in future industry; the contribution of science, technology and innovation (STI) policies to promoting the generation and real application of new technologies.

The paper follows the premise that STI Foresight, as well as Future-oriented Technology Analysis (FTA), offer a robust basis for the elaboration and monitoring of STI policies with anticipatory intelligence.
\end{abstract}

Abstract

Keywords: STI policy; foresight; new technologies; impact assessment; evaluation; employment; technology change; future industry; indicators; computerization
The core of the paper is dedicated to address the main question of how to identify and choose variables and indicators able to reflect vectors towards the future of employment. The selected vectors are referred to cross effects, trends, and time scales. As far the relationship of technology and employment is concerned, the paper examines cross effect impacts resulting from an inputoutput analysis, trends indicated in the FTA studies and time scaling of the technology lifecycle. These parameters are meant to constitute the basic elements for impact evaluation algorithms. In this connection, the paper proposes concepts, measurement techniques, and methods for the evaluation of foresight exercises influencing future changes on employment.

Linking policy-making, Foresight, and specific futurelooking themes, the paper offers building blocks for constructing standards for the evaluation of foresight exercises.

Citation: Seidl da Fonseca R. (2017) The Future of Employment: Evaluating the Impact of STI Foresight Exercises. Foresight and STI Governance, vol. 11, no 4, pp. 9-22. DOI: 10.17323/1995-459X.2016.4.9.22. 
$\mathrm{T}$ This paper is an output of the author's line of research dedicated to the theoretical and empirical conceptualization of evaluating the impact of foresight exercises. ${ }^{1}$ It addresses the impact of Science, Technology and Innovation (STI) Foresight and the STI policy resulting thereof on a critical issue of future industry studies, the demand for employment.

The importance of the consideration of the future of employment is illustrated by a key report presented at the 2017 World Economic Forum. The changing demand for employment and was discussed there as one major challenge faced as part of the Fourth Industrial Revolution [WEF, 2016].

The impact evaluation exercise on STI Foresight and employment proposed here brings together and integrates different aspects of future employment. Starting with the interdependence between employment and wellfare systems, it highlights the risks of changes in spending on salaries for the sake of converging with and sustaining social welfare models, as was examined by Zeitlin and Trubek [Zeitlin, Trubek, 2003]. Further, it considers the contribution of technological change to transformations in the structure of employment, citing Keynes [Keynes, 1936] and Aghion and Howitt [Aghion, Howitt, 1994] ${ }^{2}$. The present exercise considers the real prospects of emerging and future technologies impacting employment in the industry of the future as was discussed by Frey and Osborne [Frey, Osborne, 2015]. Another important background feature here is the contribution of STI policies in promoting the creation and real application of new technologies. ${ }^{3}$

The concrete results of STI policies in developing countries have been researched and monitored since the United Nations Conference on Science and Technology for Development, in Vienna, Austria in August 1979 [UN, 1979]. The Organisation for Economic Co-operation and Development (OECD) dedicated a breakthrough conference in May 1997 to the exploration of the concepts, theoretical and empirical approaches to the alignment of STI and industry, as well as their mutual development (see report at [OECD, 1997]). These aforementioned reports are basic sources of reference for tackling the subject of the present article.

Furthermore, the paper adheres to the premise that STI Foresight, as well as Future-oriented Technology Analysis (FTA), offer a robust foundation for the elaboration and monitoring of STI policies with anticipatory intelligence. The contribution of such forward-thinking perspectives to strategies and policy making have been emphasized by numerous works, which are summarized by Havas, Schartinger and Weber [Havas et al., 2010]. Indeed, with a systemic view, the impact evaluation exercise can be considered essential for a successful STI Foresight exercise, which shall be embedded in the formulated STI policies from the start. This view is discussed by Seidl da Fonseca and Saritas [Seidl da Fonseca, Saritas, 2005].

Against the aforementioned background, the main purpose of the paper is to address the critical question of how to identify and choose variables and indicators capable of illustrating the trends that determine the future of employment. Given the connection between technological development and employment, this article analyses the cross-effect impacts using an input-output analysis, development trends for future technologies, and also the time scales for technologies' lifecycles. These parameters are meant to constitute the basic elements for impact evaluation algorithms.

Following the basic concept that impact evaluation variables and indicators should be built into the design of foresight studies related to development policy frameworks, the present paper closes by proposing concepts, measurement techniques, and methods for the evaluation of foresight exercises and their impact upon future changes in employment.

By linking policy-making, foresight, and the selected topic of strategic research, this paper offers building blocks for the construction of a set of standards for the evaluation of foresight exercises.

\section{Methodology}

As a general approach, the structure of an impact evaluation of foresight exercises begins with the examination of FTA studies, anticipatory simulation studies, and forecasting econometric analysis to identify variables and indicators characterizing a particular sector, topic or issue.

Following our conceptualization of the impact evaluation of STI foresight exercises [Seidl da Fonseca, 2016], the selected variables and indicators can be used again in the formulation of the foresight project. This will permit a post-foresight evaluation of the outcomes of the policies and strategies implemented using the findings and recommendations found in the foresight exercises. Feedback from the impact evaluation shall be used to improve further STI foresight projects. Figure 1 below shows the flow of activities of such an approach.

\section{Why is Employment Critical for the Future of Industry?}

The last twenty years testify to a dramatic change in the conditions of employment, the demand for and supply of skills, as well as the balance between the two. A large number of jobs and career trajectories connected with certain types of activity have become a thing of the past or have been discontinued or

\footnotetext{
The first paper of this series was debated at the HSE Annual Conference on Foresight and STI Policy, Moscow, October 30-31, 2013 and published by [Seidl da Fonseca, 2016]. A draft of the present paper was presented at the HSE Annual Conference on Foresight and STI Policy, Moscow, November 6-7, 2014.

${ }^{2}$ For a summary of the evolving concepts on this feature see [Calvino, Virgillito, 2016].

${ }^{3}$ For a summary review and main references on this feature see [Martin, 2010].
} 


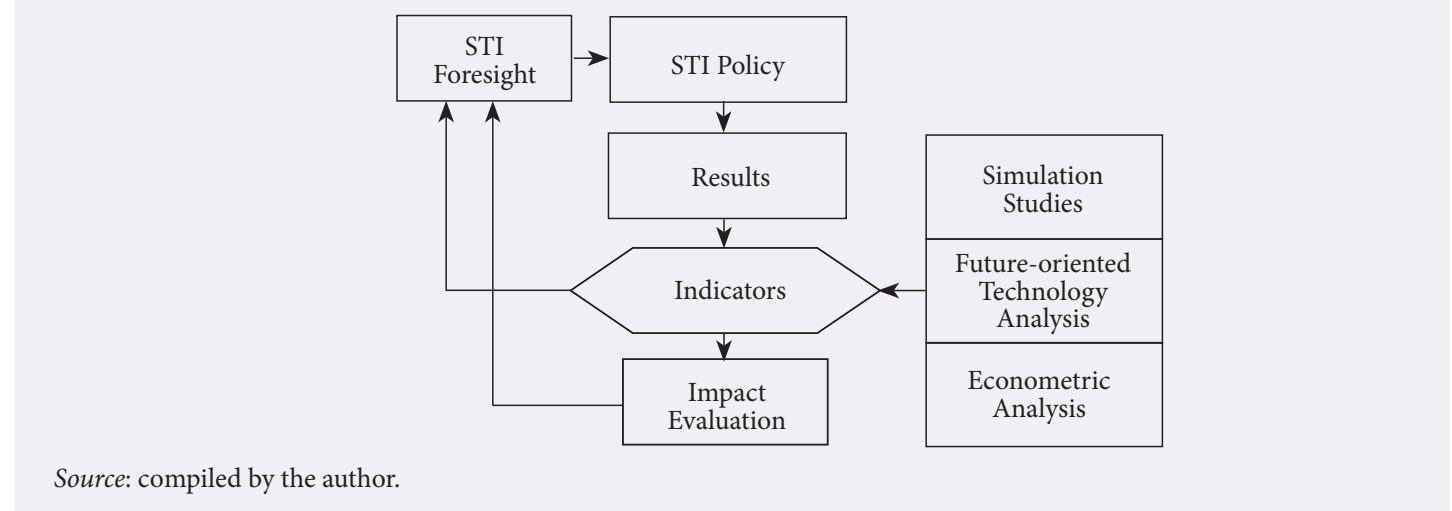

curtailed dramatically. Often, they move from one region to another, while completely new jobs and carriers have emerged.

In that period, what constituted the pillars of the modern socioeconomic framework, where salaries and taxes of the formally employed population gave rise to a complex and interlinked economic formula combining consumption, credits, savings, and public goods as well as social services and basic infrastructure, such as education, health, mobility and shelter, all has came under risk. Indeed, the growing gap in the welfare system's finances and missing public funds for social facilities have accompanied rising unemployment rates in almost all countries. Aging populations only aggravate this problem. Supporting the intricate social welfare network, including pension funds and benefits, protection for the unemployed, retraining and reallocation of labour resources, has become unstoppable process, which generates deficits for public sector accounts and places excessive burdens on the private sector.

Therefore, the stability and cohesiveness of modern society will greatly depend upon how employment behaves in the future.

Many countries have been trying different strategies and policies, on the one hand to consider and counteract the negative effects of the changing employment structures and markets, and on the other, to support the positive trends toward job creation and expansion.

Moreover, it is however recognized that both the future evolution of employment conditions and the corresponding strategies are bound to long-term and complex events deriving from the very essence of production processes and related technological changes. In this connection, FTA studies, anticipating simulation studies, as well as STI foresight exercises have been carried out and relevant policies formulated and implemented.

The focus of the present paper is on how to form a body of variables and indicators for evaluating the impact of STI foresight exercises, through their generated policies and strategies, upon employment.

\section{Concepts for Measuring Impact of Technology on Employment}

Estimating the future of employment conditions in a broader sense must consider a number of factors affecting the future supply of and demand for jobs and skills. According to experts [Mahrum et al., 2005], the factors exerting a major influence upon employment markets are the following:

- the changing size of the workforce

- the international outsourcing of skills

- an aging workforce

- technological changes

- the continuous development of the workforce.

In this paper, the pivotal question on the future of employment is to anticipate how technological progress will impact labour market outcomes in the future. That means focusing on the future relationship between technological progress and employment.

This nevertheless implies anticipating the future balance of power between state, society and economic forces influencing decisions regarding technological progress and job conservation or destruction. Since the industrial revolution, such issues have been recurrently examined and considered by the developers of economic policy, for example, recall the concept launched by Keynes on technological unemployment [Keynes, 1936]. The information technology (IT) age has opened a new chapter in the discussion on the impact of technologies upon employment, where myriads of new technologies have been used in the production of goods and services, either facilitating and creating new jobs or, on the contrary, substituting human labor. Such novelties could be designated as "new technologies affecting employment" (NTAE).

The emerging new industrial revolution, known as Industry 4.0, points to the more widespread or even full automation or robotization of the production lines, with increasingly less direct participation from labor. 
Moreover, with the dramatic technological advances experienced by now, and even more challenges foreseen in the future, studies and methodologies focused on the future of employment are in high demand. ${ }^{4}$

When considered in the narrow view, technological progress has two competing effects on employment [Aghion, Howitt, 1994]. First, as far as new technology substitutes labor, there is a destructive effect, which requires companies to reduce, close, or reallocate their labour supply; and second, there is a capitalization effect: as more companies expand or join sectors where productivity is relatively high, this leads to an increase in employment in those sectors.

Another aspect to consider is the emerging demand for skills and jobs necessary both for developing new technologies and their practical application. The introduction of new technologies could increase the productivity of directly or indirectly related occupations, for example, engineers or architects using automated systems for design and calculation activities.

Looking at all these aspects, measuring the impact of technology upon the labour force must take into consideration the different operational levels or planes, from micro- to macroeconomic ones.

\section{Assessing Cross Effect Impacts upon Employment}

Considering the conceptualization and application of strategies for stimulus programs aimed at improving the efficacy of the economic and industrial structure in a given country, the evaluation of the relative impact of such strategies could be estimated using an input-output analysis, in which specific indicators address changes in the structure and volume of employment. Two methods for measuring cross effect impacts are discussed below.

\section{Methods for Measuring the Impulse Intensity of Intersectoral Transmission of Increased labour Productivity ${ }^{5}$}

This impact criterion captures the impulse that an increase (or decrease) of labour productivity in one given sector is transmitted to other sectors.

In industry, such an impulse has an effect on the man-machine system and if such changes results in changing the value added, physical output, or labour efforts, there is a shift in the production function. ${ }^{6}$ Technological progress inevitably affects labour productivity. This change in technology results in shifts in work qualifications (skills) and/or work conditions (work methods and production equipment). One can measure the efficiency of labor's contribution to the production process using an indicator for labour productivity. labour productivity $(p t)$ shows the relationship between the physical results of the production process or business and related work efforts. The mathematical equation is as follows:

$p t=\frac{e(\text { or } v)}{l(\text { or } s l)}$

where: production results are value added $(e)$ or the physical output $(v)$; work efforts involve the number of workers $(l)$ or the working hours $(s l)$.

Accordingly, the labour productivity increases if the added ivalue ncreases or the work effort decreases.

To measure the impact upon employment of a technological change in a selected sector, two methods described below can be used.

\section{a. Method of the Relative Employment Proportion of an Industrial Sector}

The relative share of employment in a sector indicates the potential importance of this sector with respect to its ability to transmit increased labour productivity to the whole production structure. An indicator for this is the direct employment coefficient $(b)$, which classifies the sectors as high, middle, and low labour intensive. The equation is the following:

$b=\frac{s l(\text { or } l)}{e(\text { or } v)}$

Table 1 below presents the calculation of the direct employment coefficient and relative grouping and ranking ${ }^{7}$ for a set of industries in the USA (2015). By identifying and ranking the existing sectors in an economy, it is possible in the planning process, both during the implementation and during the evaluation of a stimulus program to examine or use the sectors with a higher potential of transmitting increased

\footnotetext{
${ }^{4}$ An example of this can be found in the study conducted by the UK Commission for Employment and Skills "Future of Work: Jobs and Skills in 2030" [CES, 2014]. This study is dedicated to forecasting the future of labour markets, where according to different scenarios about future social, demographic, political, or economic perspectives, one can derive the possible or expected changes in the structure of employment and the job market, and indicate strategic actions.

${ }^{5}$ Elaborated upon in [Seidl da Fonseca, 1981].

${ }^{6}$ The production function is a mathematical equation or graph that shows the relationship between the inputs and outputs of a production process or business. Inputs and outputs can be expressed in physical or monetary terms.

Ranking and grouping are done for the year 2004.
} 


\section{Table 1. Grouping and Ranking of Industries by Direct Employment Coefficient}

\begin{tabular}{|c|c|c|c|c|}
\hline \multirow{2}{*}{ Industry } & \multirow{2}{*}{2012 NAICS $^{\star}$} & \multicolumn{3}{|c|}{ Direct employment coefficient $(\mathbf{b})^{\star *}$} \\
\hline & & 2004 & 2014 & 2024 \\
\hline Apparel, leather, and allied manufacturing & 315,316 & 8.12 & 6.06 & 3.30 \\
\hline Metalworking machinery manufacturing & 3335 & 7.47 & 5.27 & 4.47 \\
\hline Clay product and refractory manufacturing & 3271 & 6.39 & 5.56 & 4.23 \\
\hline Furniture and related product manufacturing & 337 & 6.29 & 5.60 & 4.43 \\
\hline Ship and boat building & 3366 & 5.45 & 3.89 & 3.41 \\
\hline Wood product manufacturing & 321 & 5.40 & 4.78 & 3.97 \\
\hline Textile mills and textile product mills & 313,314 & 5.12 & 4.61 & 3.39 \\
\hline Construction & 23 & 5.00 & 5.95 & 5.10 \\
\hline \multicolumn{5}{|c|}{ Middle-high labour intensive $(3.00 \leq b \leq 5.00)$} \\
\hline Cutlery and hand tool manufacturing & 3322 & 4.96 & 3.64 & 2.52 \\
\hline Computer and peripheral equipment manufacturing & 3342 & 4.95 & 2.19 & 1.29 \\
\hline Electric lighting equipment manufacturing & 3351 & 4.89 & 3.76 & 2.44 \\
\hline Bakeries and tortilla manufacturing & 3118 & 4.57 & 4.64 & 3.95 \\
\hline Glass and glass product manufacturing & 3272 & 4.52 & 3.85 & 2.57 \\
\hline Foundries & 3315 & 4.32 & 3.64 & 2.68 \\
\hline Water, sewage and other systems & 2213 & 4.30 & 4.83 & 4.82 \\
\hline Rubber product manufacturing & 3262 & 4.13 & 3.58 & 2.73 \\
\hline Seafood product preparation and packaging & 3117 & 3.79 & 3.22 & 2.54 \\
\hline Cement and concrete product manufacturing & 3273 & 3.78 & 3.25 & 2.48 \\
\hline Plastics product manufacturing & 3261 & 3.52 & 3.44 & 2.49 \\
\hline Household appliance manufacturing & 3352 & 3.44 & 2.73 & 1.82 \\
\hline Industrial machinery manufacturing & 3332 & 3.30 & 2.06 & 1.60 \\
\hline Aerospace product and parts manufacturing & 3364 & 2.83 & 2.09 & 1.64 \\
\hline Alumina and aluminium production and processing & 3313 & 2.15 & 1.35 & 1.15 \\
\hline Communications equipment manufacturing & 3342 & 2.07 & 1.54 & 0.93 \\
\hline \multicolumn{5}{|c|}{ Middle-low labour intensive $(1.00 \leq b \leq 3.00)$} \\
\hline Mining, except oil and gas & 212 & 1.91 & 2.03 & 1.68 \\
\hline Beverage manufacturing & 3121 & 1.84 & 1.79 & 1.59 \\
\hline Pulp, paper, and paperboard mills & 3221 & 1.69 & 1.40 & 0.92 \\
\hline Paint, coating, and adhesive manufacturing & 3255 & 1.64 & 1.82 & 1.37 \\
\hline Electric power generation, transmission and distribution & 2211 & 1.26 & 1.50 & 1.10 \\
\hline $\begin{array}{l}\text { Resin, synthetic rubber, and artificial synthetic fibbers and filaments } \\
\text { manufacturing }\end{array}$ & 3252 & 1.24 & 1.09 & 0.78 \\
\hline Iron and steel mills and ferroalloy manufacturing & 3311 & 1.18 & 0.89 & 0.80 \\
\hline \multicolumn{5}{|c|}{ Low labour intensive $(b<1.00)$} \\
\hline Motor vehicle manufacturing & 3361 & 0.92 & 0.65 & 0.56 \\
\hline Grain and oilseed milling & 3112 & 0.79 & 0.59 & 0.47 \\
\hline Basic chemical manufacturing & 3251 & 0.76 & 0.66 & 0.48 \\
\hline Oil and gas extraction & 211 & 0.60 & 0.74 & 0.69 \\
\hline Tobacco manufacturing & 3122 & 0.48 & 0.27 & 0.21 \\
\hline Petroleum and coal products manufacturing & 324 & 0.24 & 0.21 & 0.16 \\
\hline
\end{tabular}

(or decreased) labour productivity to related sectors. These areas of high potential can be considered the drivers of development, which are of special interest to foresight studies.

Organizing the data provided in the Table 1 in a way to give indications on how the analyzed industrial sectors would behave in relation to their ability to provide direct employment, Tables 2 and 3 below present information on how those sectors change their capacity to create jobs over the years and their ranking of importance as employment development drivers.

Foresight exercises may consider trends, derived from future scenarios, for the direct employment impact in selected industrial sectors when changes that might influence employment, such as productivity or technological progress, are expected in the future.

\section{b. Method for Evaluating the Total Employment Efficiency}

One basic research question that considers the impact of changes on the economy concerns how they affect employment opportunities and structure. For foresight exercises, future economic trends should be compared with the prospects for job creation or destruction. The identification of sectors more sensitive to such an influence and an analysis of the consequences of such changes may serve as an impetus for a more grounded and focused study of future trends in the relevant areas. 


\section{Table 2. Capacity to Create Jobs by Industry and Year}

\begin{tabular}{|c|c|c|c|c|c|c|}
\hline Industry & 2004 & & 2014 & & 2024 & \\
\hline Apparel, leather, and allied manufacturing & 8 & 8.12 & 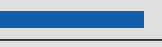 & 6.06 & 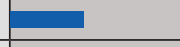 & 3.30 \\
\hline Metalworking machinery manufacturing & 7 & 7.47 & 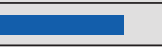 & 5.27 & + & 4.47 \\
\hline Clay product and refractory manufacturing & 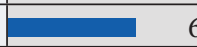 & 6.39 & 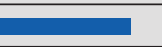 & 5.56 & +2 & 4.23 \\
\hline Furniture and related product manufacturing & 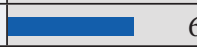 & 6.29 & 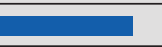 & 5.60 & +2 & 4.43 \\
\hline Ship and boat building & 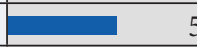 & 5.45 & 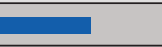 & 3.89 & 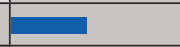 & 3.41 \\
\hline Wood product manufacturing & 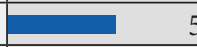 & 5.40 & 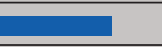 & 4.78 & 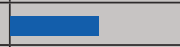 & 3.97 \\
\hline Textile mills and textile product mills & +2 & 5.12 & 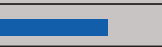 & 4.61 & 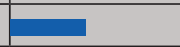 & 3.39 \\
\hline Construction & 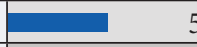 & 5.00 & 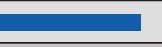 & 5.95 & 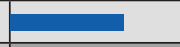 & 5.10 \\
\hline Cutlery and hand tool manufacturing & 年 & 4.96 & 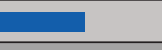 & 3.64 & 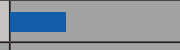 & 2.52 \\
\hline Computer and peripheral equipment manufacturing & 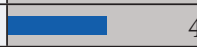 & 4.95 & 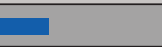 & 2.19 & 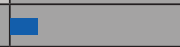 & 1.29 \\
\hline Electric lighting equipment manufacturing & 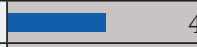 & 4.89 & & 3.76 & 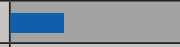 & 2.44 \\
\hline Bakeries and tortilla manufacturing & 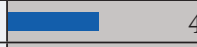 & 4.57 & 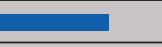 & 4.64 & 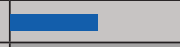 & 3.95 \\
\hline Glass and glass product manufacturing & 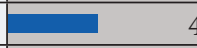 & 4.52 & 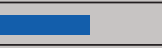 & 3.85 & 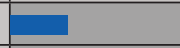 & 2.57 \\
\hline Foundries & 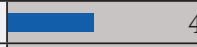 & 4.32 & 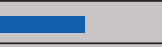 & 3.64 & 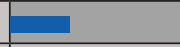 & 2.68 \\
\hline Water, sewage and other systems & 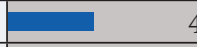 & 4.30 & 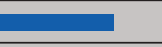 & 4.83 & 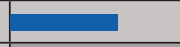 & 4.82 \\
\hline Rubber product manufacturing & 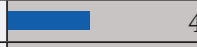 & 4.13 & 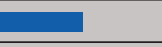 & 3.58 & 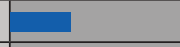 & 2.73 \\
\hline Seafood product preparation and packaging & 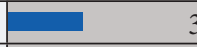 & 3.79 & 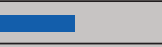 & 3.22 & 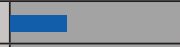 & 2.54 \\
\hline Cement and concrete product manufacturing & 更 & 3.78 & 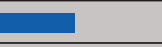 & 3.25 & 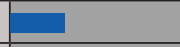 & 2.48 \\
\hline Plastics product manufacturing & 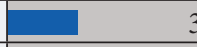 & 3.52 & 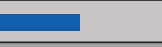 & 3.44 & 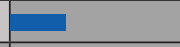 & 2.49 \\
\hline Household appliance manufacturing & 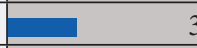 & 3.44 & 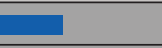 & 2.73 & 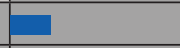 & 1.82 \\
\hline Industrial machinery manufacturing & 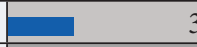 & 3.30 & 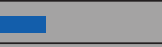 & 2.06 & 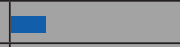 & 1.60 \\
\hline Aerospace product and parts manufacturing & 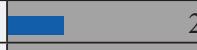 & 2.83 & 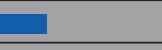 & 2.09 & 四 & 1.64 \\
\hline Alumina and aluminium production and processing & + & 2.15 & 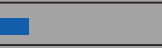 & 1.35 & $E$ & 1.15 \\
\hline Communications equipment manufacturing & 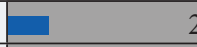 & 2.07 & 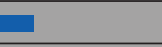 & 1.54 & $\theta$ & 0.93 \\
\hline Mining, except oil and gas & 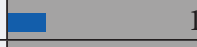 & 1.91 & 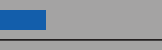 & 2.03 & - & 1.68 \\
\hline Beverage manufacturing & 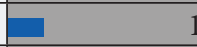 & 1.84 & 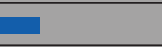 & 1.79 & 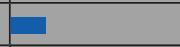 & 1.59 \\
\hline Pulp, paper, and paperboard mills & 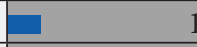 & 1.69 & 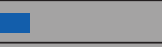 & 1.40 & E & 0.92 \\
\hline Paint, coating, and adhesive manufacturing & 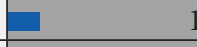 & 1.64 & 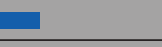 & 1.82 & E & 1.37 \\
\hline Electric power generation, transmission and distribution & 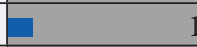 & 1.26 & 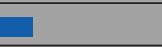 & 1.50 & 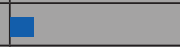 & 1.10 \\
\hline Resin and artificial synthetic rubber, fibbers and filaments manufacturing & 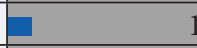 & 1.24 & 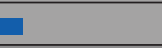 & 1.09 & 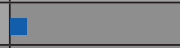 & 0.78 \\
\hline Iron and steel mills and ferroalloy manufacturing & - & 1.18 & 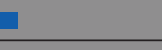 & 0.89 & 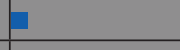 & 0.80 \\
\hline Motor vehicle manufacturing & 1 & 0.92 & 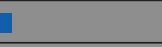 & 0.65 & 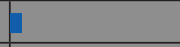 & 0.56 \\
\hline Grain and oilseed milling & P & 0.79 & 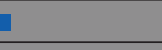 & 0.59 & 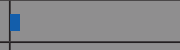 & 0.47 \\
\hline Basic chemical manufacturing & P & 0.76 & 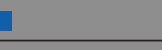 & 0.66 & 1 & 0.48 \\
\hline Oil and gas extraction & 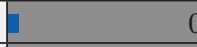 & 0.60 & 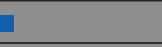 & 0.74 & 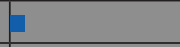 & 0.69 \\
\hline Tobacco manufacturing & + & 0.48 & & 0.27 & & 0.21 \\
\hline Petroleum and coal products manufacturing & c & 0.24 & & 0.21 & & 0.16 \\
\hline \multicolumn{7}{|l|}{ Labour intensivity: } \\
\hline Middle-high $(3.00 \leq \mathrm{b} \leq 5.00)$ & \multicolumn{3}{|c|}{ Middle-low $(1.00 \leq \mathrm{b} \leq 3.00)$} & \multicolumn{3}{|c|}{ Low $(b<1.00)$} \\
\hline Source: compiled by the author based on [BLS, 2015]. & & & & & & \\
\hline
\end{tabular}

In this connection, with the method of total employment efficiency, one can estimate the effect of a change in the production capacity of a selected sector upon the number of employees in other sectors.

Employment efficiency helps one uncover the ability of a sector to transmit increased (or decreased) labour productivity to other related industries. With the application of the concepts and data processing of the Input-Output Matrix ${ }^{8}$, the employment efficiency of a sector can be estimated through the Leontief inverse [Leontief, 1986]. According to Bacon and Kojima [Bacon, Kojima, 2011] ${ }^{9}$, the use of Input-Output tables may answer two basic, relevant questions:

\footnotetext{
${ }^{8}$ Defined by Bacon and Kojima [Bacon, Kojima, 2011]: "The standard IO model of an economy links the gross output of a sector to the final demand for that sector and to the intermediate demands made by other sectors for its output. This can be expressed as $\mathrm{X}=\mathrm{A} \mathrm{X}+\mathrm{F}$, where $\mathrm{X}$ is a vector of gross outputs of the $\mathrm{N}$ sectors of the economy, $\mathrm{F}$ is a vector of final demands for these sectors, and $\mathrm{A}$ is the $\mathrm{N} \times \mathrm{N}$ matrix of technical coefficients that indicate how much output from sector $\mathrm{i}$ is directly required to produce one unit in sector $\mathrm{j}$. The gross output is then related to final demand by the equation $\mathrm{X}=(\mathrm{I}-\mathrm{A})^{-1} \mathrm{~F}=\mathrm{CF}$, where the coefficient matrix C (Leontief inverse) measures the total amount of sector $\mathrm{i}$ that is required to be produced in order to satisfy the direct and indirect demands produced by a one-unit increase in the final demand for sector $\mathrm{j}$.

The study done by Bacon and Kojima [Bacon, Kojima, 2011] is an example of a work dedicated to the impact of a broad or pervasive technological field, where alternatives for its development would result in the expansion or reduction of job capacities in one or more areas. This paper was prepared for the World Bank and estimates the impact of labour upon the energy sector.
} 
Table 3. Ranking of Sectors by Importance as Drivers of Employment Development

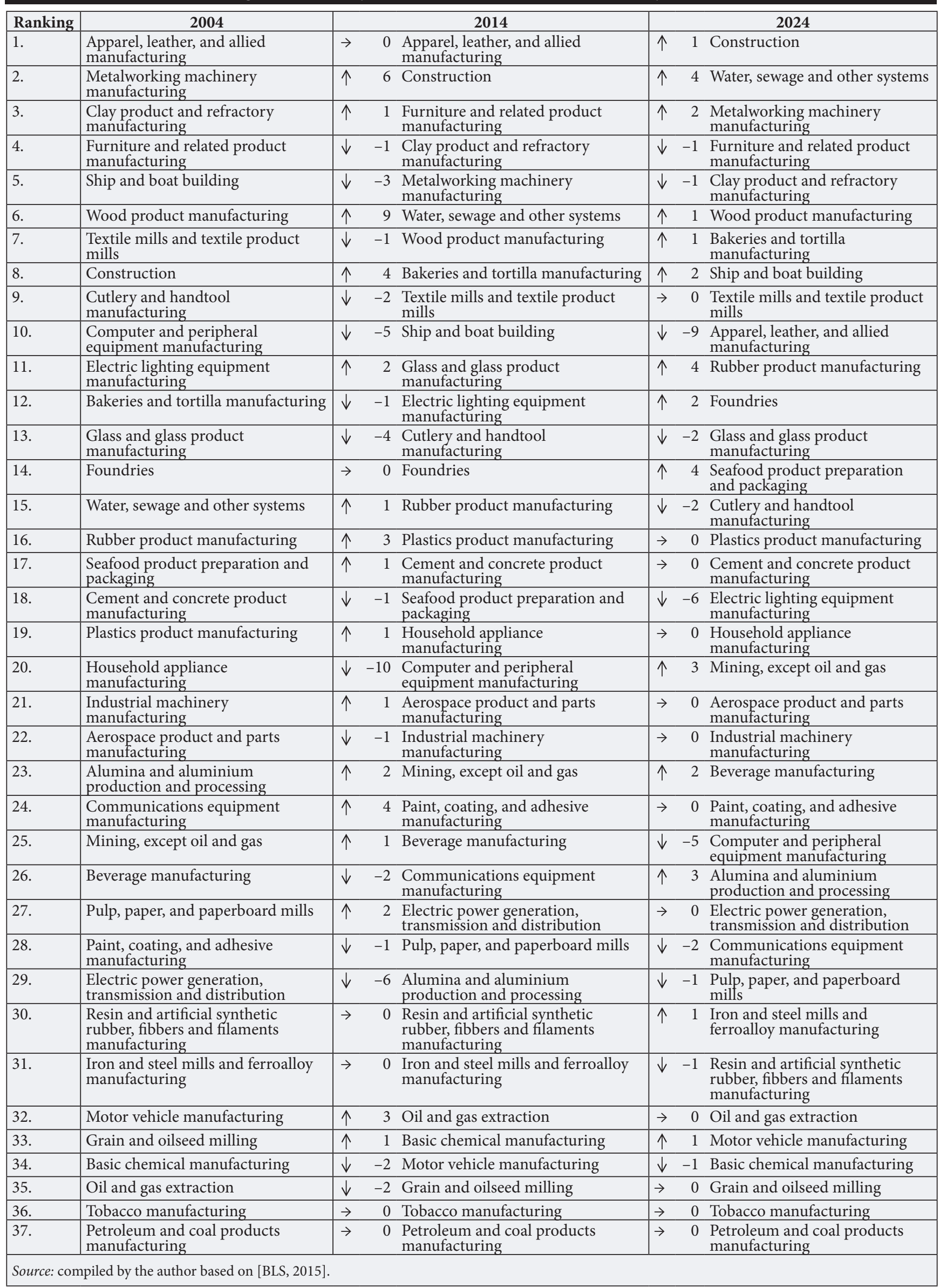


1. How many jobs are currently supported by a given sector?

2. If demand for the output of the sector changes by a certain amount, how many extra jobs would be created?

In addition, the total change in the induced employment at indirectly and directly affected sectors is considered, which can be influenced if the sector under consideration experiences an increase (or decrease) in its final demand.

For such an estimation, the individual direct employment coefficient $[\mathrm{B}]^{10}$ of the selected sectors are allocated along a diagonal matrix and multiplied by the Leontief inverse matrix [C], thus forming the employment inverse matrix [CL] :

$[\mathrm{CL}]=[\mathrm{C}] \mathrm{x} \operatorname{diag}[\mathrm{B}]$

where: $[\mathrm{CL}]=\left[\mathrm{cl}_{\mathrm{ij}}\right] ;[\mathrm{C}]=\left[\mathrm{c}_{\mathrm{ij}}\right] ;[\mathrm{B}]=\left[\mathrm{b}_{\mathrm{j}}\right]$.

The single elements of the column $\left[\mathrm{cl}_{\mathrm{ij}}\right]$ of the employment inverse matrix estimate the induced change in the number of employees in sector $\mathrm{i}$ when the capacity of sector $\mathrm{j}$ changes by one unit.

The column sum $\left[\mathrm{cl}_{\mathrm{j}}\right]$ for all industrial sectors $\mathrm{i}(\mathrm{i}=1,2 \ldots \mathrm{n})$ indicates the total impact triggered by sector $\mathrm{j}$ upon the number of employees in all relevant industrial sectors.

The figure $\left[\mathrm{cl}_{\mathrm{j}}\right]$ represents the direct and indirect employment coefficient of sector $\mathrm{j}$ and calculates the total employment efficiency of the sector.

The difference between the direct employment coefficient $\left[\mathrm{b}_{\mathrm{j}}\right]$ and the total employment coefficient $\left[\mathrm{cl}_{\mathrm{j}}\right]$ represents the changes in the number of employees in all sectors besides sector $\mathbf{j}$.

Similar to the determination of transmission intensity, the figure $\mathrm{p}^{\mathrm{L}}{ }_{\mathrm{j}}$ measures the relative intensity of the employment efficiency in sector $\mathrm{j}$ in comparison with all other sectors.

For an inter-sectoral comparison, the average column sum over the total average of all elements of the employment inverse can be used:

$p_{. j}^{L}=\frac{\frac{1}{n} \sum_{i=1}^{n} c l_{i j}}{\frac{1}{n^{2}} \sum_{i=1}^{n} \sum_{j=1}^{n} c l_{i j}}=\frac{n \times c l_{. j}}{\sum_{j=1}^{n} c l_{. j}}$

A value $\mathrm{p}^{\mathrm{L}}{ }_{\mathrm{j}}>1$ indicates that the relevant sector $\mathrm{j}$ transmits an above average intensive impulse on employment in other industries.

The total employment efficiency coefficient $\mathrm{cl}_{. j}$ and the relative transmission intensity $\mathrm{p}^{\mathrm{L}}{ }_{\mathrm{j}}$ can be used for ranking the individual sectors.

Table 4 below proposes a way of using the employment-related indicators presented above for ranking a group of selected sectors according to the strength of each sector expressed by cross impacts upon the employment capacity of all other sectors in the group. ${ }^{11}$

The identification of systemic relationships between different sectors in the economy using this method is also very useful for designing foresight exercises, particularly for scenario building.

\section{Measurement of Technological Change Trends}

The indicators of trends can be identified by empirical research carried out in the framework of FTA. Understanding the critical question of employment in the future, FTA studies dedicated specifically to this issue have been conducted. These studies revealed not only the relevant parameters and drivers but also reliable indicators of variation in levels of employment, which could correspond to specific or generic technological changes.

The present paper extracted some indicators from a FTA study conducted by Frey and Osborne [Frey, Osborne, 2013] upon the impact of a specific new technology, where its introduction would imply job creation or destruction.

\section{Method for Measuring the Risk of job Destruction due to the Introduction of New Technologies}

A constant consideration regarding technology progress is the possibility of new technologies being used in the production process, which in turn forces a reduction in jobs, a decline in workers' skills, substitution, displacement or disappearance.

Frey and Osborne [Frey, Osborne, 2013] developed a procedure for categorizing occupations according to their susceptibility to new technologies and therefore estimate the number of jobs at risk using the

\footnotetext{
${ }^{10}$ The employment coefficient represents the absolute number of employees (l) per gross production value or capacity (v) of the individual sector: $b=l / v$.

${ }^{11}$ Presented here simply for illustrative purposes, the numbers in the table are taken from the Input-Output Table of Brazil for a selected group of industries in 1970 [IBGE, 1974]. It is worth noting that the calculation and ranking of industrial sectors on the basis of the Leontief inverse [Leontief, 1986] depends on the group of selected sectors considered in each concrete study.
} 
Table 4. Ranking of Industries by Employment Indicators

\begin{tabular}{|c|c|c|c|}
\hline Industrial sector & cl.j & {$[c l . j-b j]$} & $p L . j$ \\
\hline Shoes & 64.21 & 12.78 & 2.43 \\
\hline Wood processing & 52.74 & 11.82 & 1.99 \\
\hline Textiles (natural fibres) & 50.40 & 7.38 & 1.90 \\
\hline Garment & 47.56 & 17.65 & 1.80 \\
\hline Mining & 38.76 & 2.11 & 1.46 \\
\hline Leatherworking & 37.62 & 8.33 & 1.42 \\
\hline Agro machinery & 36.42 & 8.45 & 1.37 \\
\hline Iron, Steel and Casting processing & 35.81 & 4.43 & 1.35 \\
\hline Machine tools & 34.51 & 6.65 & 1.30 \\
\hline Glass & 32.93 & 4.52 & 1.24 \\
\hline Textiles (synthetic fibres) & 32.48 & 8.78 & 1.22 \\
\hline Iron, Metal plates and products & 32.13 & 6.51 & 1.21 \\
\hline Paper and Cellulose processing & 30.58 & 5.81 & 1.15 \\
\hline Electro-technical industry & 29.68 & 6.67 & 1.12 \\
\hline \begin{tabular}{|l|} 
Plastics \\
\end{tabular} & 24.38 & 5.48 & 0.92 \\
\hline Shipbuilding & 24.25 & 9.72 & 0.91 \\
\hline Car industry & 20.44 & 13.74 & 0.77 \\
\hline Oil and Gas & 17.86 & 0.49 & 0.67 \\
\hline Cement & 15.59 & 5.27 & 0.59 \\
\hline Chemicals & 14.64 & 3.95 & 0.55 \\
\hline Food industry & 14.51 & 3.34 & 0.54 \\
\hline Tobacco & 13.74 & 2.64 & 0.52 \\
\hline
\end{tabular}

example of computerization. ${ }^{12}$ The application of the method by the authors was used to estimate the impact of computerization on the US labour market.

The exercise considers a set of defined occupations, using available occupation catalogues, which specify in detail the characteristics of each occupation, such as the US-based O*NET database. ${ }^{13 .}$

On the basis of the descriptions of the occupations, the method examines how each one is susceptible to computerization and estimates their probability of automation. Thus, the degree of computerization of jobs and how widely this technological process spreads will depend upon the potential of the latest technologies to provide engineering solutions.

Following this evaluation, the results will be applied to the study of the expected consequences for the labour market connected with the introduction a new technology, such as computerization. First, jobs at risk are analysed and identified and the relationship between an occupation's probability of automation by a new technology (computerization), wages, and educational advancement is considered.

According to Frey and Osborne [Frey, Osborne, 2013], "from a technological capabilities point of view, we aim to determine which problems engineers need to solve for specific occupations to be automated. By highlighting these problems, their difficulty and to which occupations they relate, we categorise jobs according to their susceptibility to computerization. The characteristics of these problems were matched to different occupational characteristics, using $\mathrm{O}^{\star} \mathrm{NET}$ data, allowing us to examine the future direction of technological change in terms of its impact on the occupational composition of the labour market, but also the number of jobs at risk should these technologies materialise."

In general terms, such a method could be used to estimate the impact of the introduction of new technologies upon occupations.

Based on the description above, the method follows the steps:

1. The identification of engineering bottlenecks for new technologies (computerization) in occupations

2. An evaluation of the potential of new technologies (computer-controlled equipment) to perform the job-related tasks at various levels of difficulty

3. An analysis of the susceptible and non-susceptible labour inputs

4. An evaluation of the possible level of technological change (computerization)

5. Correlating employment/labor inputs with the level of technological change (computerization or computer capital) per occupation and per mix of jobs

6. The identification of the volume of employment inputs at risk of being substituted by new technologies (computer-controlled equipment)

\footnotetext{
${ }^{12}$ Computerization is defined as job automation by means of computer-controlled equipment.

${ }^{13}$ The $\mathrm{O}^{*}$ NET program developed by the US Department of labour is the USA's primary source of occupational information (URL: www.onetcenter.org, last accessed 04.10.2016).
} 
In the case of the original method, according to the literature and expert opinions, the computerization bottlenecks are related to the performance of three critical tasks: perception and manipulation, creative intelligence, and social intelligence. Table 5 below presents the corresponding $\mathrm{O}^{\star} \mathrm{NET}$ variables for each task category.

For each occupation selected for analysis, the composition and importance of these variables in the occupation characteristics, would lead experts to determine that these labour inputs are not susceptible to computerization.

According to these findings, non-susceptible labour inputs $\left(L_{N S}\right)$ can be described as [Frey, Osborne, 2013, p. 24]:

$L_{N S}=\sum_{i=1}^{n}\left(L_{P M, i}+L_{C, i}+L_{S L, i}\right)$

where $L_{P M}, L_{C}$ and $L_{S I}$ are labour inputs into perception and manipulation tasks, creative intelligence tasks, and social intelligence tasks.

The authors describe their estimation process as follows [Frey, Osborne, 2013, p. 30]:

"We combine and build upon two approaches. First, together with a group of ML researchers, we subjectively hand-labelled 70 occupations, assigning 1 if automatable, and 0 if not. For our subjective assessments, we draw upon a workshop (probably in 2013) held at the Oxford University Engineering Sciences Department, examining the automatability (or probability of computerization) of a wide range of tasks. Our label assignments were based on eyeballing the $\mathrm{O}^{\star} \mathrm{NET}$ tasks and job description of each occupation. This information is particular to each occupation, as opposed to standardised across different jobs. The hand-labelling of the occupations was made by answering the question "Can the tasks of this job be sufficiently specified, conditional on the availability of big data, to be performed by state of the art computer-controlled equipment". Thus, we only assigned a 1 to fully automatable occupations, where we considered all tasks to be automatable. To the best of our knowledge, we considered the possibility of task simplification, possibly allowing some currently non-automatable tasks to be automated. Labels were assigned only to the occupations about which we were most confident. Second, we use objective $\mathrm{O}^{\star} \mathrm{NET}$ variables corresponding to the defined bottlenecks to computerisation. More specifically, we are interested in variables describing the level of perception and manipulation, creativity, and social intelligence required to perform it. As reported in Table I, we identified nine variables that describe these attributes. These variables were derived from the $\mathrm{O}^{\star} \mathrm{NET}$ survey, where the respondents are given multiple scales, with "importance" and "level" as the predominant pair. We rely on the "level" rating, which corresponds to specific examples about the capabilities required of computer-controlled equipment to perform the tasks of an occupation. For instance, in relation to the attribute "Manual Dexterity", low (level) corresponds to "Screw a light bulb into a light socket"; medium (level) is exemplified by "Pack oranges in crates as quickly as possible"; high (level) is described as "Perform open-heart surgery with surgical instruments". This gives us an indication of the level of "Manual Dexterity" computer-controlled equipment would require to perform a specific occupation."

Other critical step is correlating employment/labor inputs versus the potential for technological change (computerization or computer capital), per occupation and per mix of jobs.

Based on the Cobb-Douglas [Cobb, Douglas, 1928] production function, such a correlation can be formulated as:

\section{Table 5. $\mathbf{O}^{\star}$ NET Variables that Serve as Indicators of Bottlenecks or Barriers to Computerization}

\begin{tabular}{|l|l|l|}
\hline \multicolumn{1}{|c|}{$\begin{array}{c}\text { Computerization } \\
\text { Bottleneck }\end{array}$} & \multicolumn{1}{|c|}{ O*NET Variable } & \multicolumn{1}{c|}{ O*NET Description } \\
\hline $\begin{array}{l}\text { Perception and } \\
\text { Manipulation }\end{array}$ & Finger Dexterity & $\begin{array}{l}\text { The ability to make precisely coordinated movements of the fingers of one or } \\
\text { both hands to grasp, manipulate, or assemble very small objects. }\end{array}$ \\
\cline { 2 - 3 } & Manual Dexterity & $\begin{array}{l}\text { The ability to quickly move your hand, your hand together with your arm, or } \\
\text { your two hands to grasp, manipulate, or assemble objects. }\end{array}$ \\
\cline { 2 - 3 } & $\begin{array}{l}\text { Cramped Work Space, } \\
\text { Awkward Positions }\end{array}$ & $\begin{array}{l}\text { How often does this job require working in cramped work spaces that requires } \\
\text { getting into awkward positions? }\end{array}$ \\
\hline Creative Intelligence & Originality & $\begin{array}{l}\text { The ability to come up with unusual or clever ideas about a given topic or } \\
\text { situation, or to develop creative ways to solve a problem. }\end{array}$ \\
\cline { 2 - 3 } & Fine Arts & $\begin{array}{l}\text { Knowledge of theory and techniques required to compose, produce, and } \\
\text { perform works of music, dance, visual arts, drama, and sculpture. }\end{array}$ \\
\hline Social Intelligence & Social Perceptiveness & Being aware of others' reactions and understanding why they react as they do. \\
\cline { 2 - 3 } & Negotiation & Bringing others together and trying to reconcile differences. \\
\cline { 2 - 3 } & Persuasion & $\begin{array}{l}\text { Providing personal assistance, medical attention, emotional support, or other } \\
\text { personal care to others such as co-workers, customers, or patients. }\end{array}$ \\
\cline { 2 - 3 } & $\begin{array}{l}\text { Assisting and Caring for } \\
\text { Others }\end{array}$ \\
\hline \multirow{2}{*}{ Source: [Frey, Osborne, 2013, Table I, p. 31]. } & \\
\hline
\end{tabular}




\section{Figure 2. Susceptibility of Occupations to Technological Change}

Source: compiled by the author.

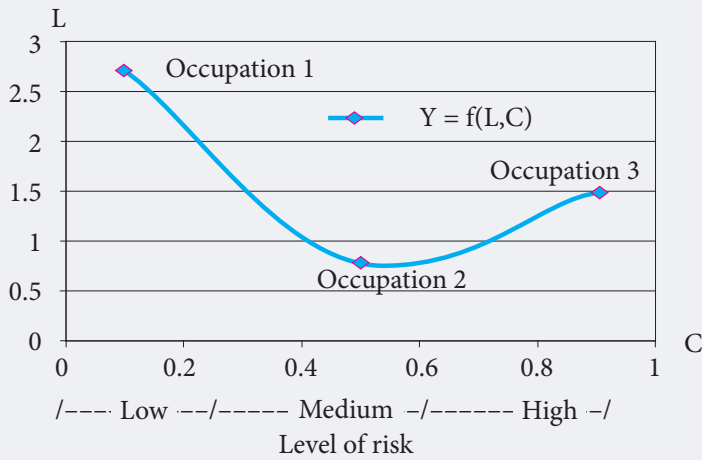

$Y=\left(L_{S}+C\right)^{1-\beta} L_{N S}^{\beta}, \beta \in(0,1)$

where: Y — production level; $L_{S}$ - susceptible labour inputs; $L_{N S}-$ non-susceptible labour inputs; $C-$ technological change level or grade (computer capital)

For estimating the volume of employment inputs at risk of being substituted by new technologies, the aforementioned function can be plotted in an isoquant for each production level $Y=\mathrm{f}(L, C)$, where Y: production level; L: labour inputs; C: technological change grade (computer capital); $C \in(0,1)$.

The study done on the impact of computerization in the USA indicated that about 47 percent of total US employment would be within the high-risk category [Frey, Osborne, 2013, p. 38]. Figure 3 below shows the correlation between the job mix categories and the potential for computerization.

\section{Measurement of the Timeframe for Impact Assessment}

In order to estimate the future impact of technological change upon employment, the concepts of technological life cycle, its expansion, and diffusion can be employed.

Firstly, for a given technology, its growth and decline are represented by its life cycle. The history of technology and its industrial application is full of empirical examples. The velocity of advancement from innovation to mature technology and the velocity with which a technology moves from late maturity to obsolescence are critical for employment. These processes correspond corresponding respectively to the increase and stability of jobs and to the decline and substitution of jobs. The empirical or forecasted velocity of the advancement of a given technology indicates how rapidly that technology is available for industrial application in comparison with similar or competing technologies. The speed with which a technology evolves and the necessary timeframe for it to move through the different stages of its lifecycle are related to its industrial dynamics and commercial behavior, which can indicate the number of jobs in related industries. The speed with which a technology becomes obsolete determines those jobs at risk. Figure 4 below presents the hypothetical trajectory of incremental or continuous technological

\section{Figure 3. Distribution of BLS 2010 Occupational Employment over the Probability of Computerization,} Along with the Share of Low, Medium and High Probability Categories

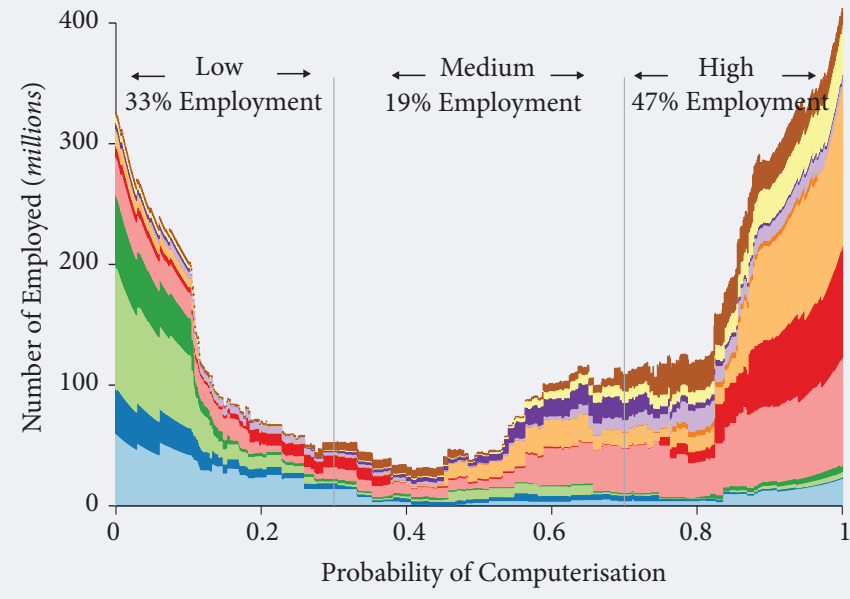

Management, Business, and Financial

Computer, Engineering, and Science

Education, Legal, Community Service, Arts, and Media

Healthcare Practitioners and Technical Service

Sales and Related

Office and Administrative Support

Farming, Fishing, and Forestry

Construction and Extraction

Installation, Maintenance, and Repair

Production

Transportation and Material Moving 
Figure 4. Technological Advancement Lifecycle

Source: compiled by the author based on [UN-ESCAP, 1984].

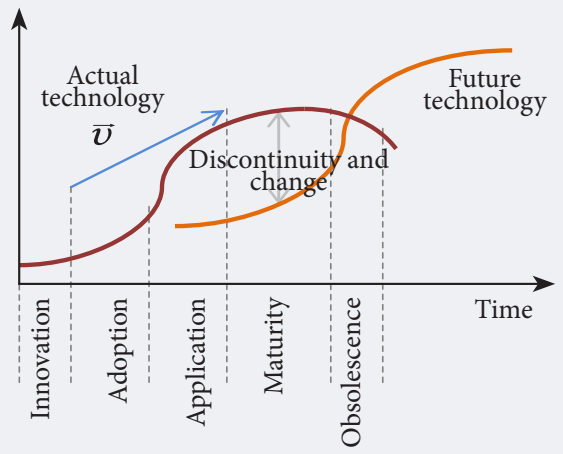

development over time through the different stages of its lifecycle: innovation, adoption, industrial application, maturity, and obsolescence. One curve represents a given actual technology and another - a future technology, which would substitute the first once it reaches obsolescence.

In reality, the probability of the adoption and application of a new disruptive technology in the production process or the final product depends upon its acceptability on the market and the willingness or propensity of consumers to substitute the technology or product with a new one. ${ }^{14}$

According to this concept, following parameters, affecting labour inputs, would be relevant for estimating the impact of technological advancement upon employment.

$$
L=f\left(\vec{v}_{\mathrm{A}}, \vec{v}_{\mathrm{O}}, \Delta T_{a \rightarrow m}, \Delta T_{m \rightarrow 0}, \Delta T_{m}, P_{\mathrm{a}}\right),
$$

where: $L-$ labour inputs; $\vec{v}_{\mathrm{A}}-$ velocity of advancement; $\vec{v}_{\mathrm{O}}-$ velocity of obsolescence; $\Delta T_{a \rightarrow m}-$ period of time from adoption/application to maturity; $\Delta T_{m-0}$ - period of time from (late) maturity to obsolescence; $\Delta T_{m}$ - period of maturity; $P_{\mathrm{a}}$ - probability of adoption/application of a given technology. Secondly, one must consider the expansion and diffusion phenomena of a technology spreading over the various planes of industrial application: innovation cell, application case, plant, sector, and macroeconomy. The speed of the technological diffusion and expansion is relevant for the increase or decrease of employment.

Figure 5 below illustrates the expansion and diffusion of technology across the different planes of application. The figure also presents an example of the advancement of a critical industrial technology related to those planes. One could say that each technological cluster evolves from a given critical technology diffused at one plane, which expands across subsequent planes. The example considers tone decoder technology a critical development in electronic sensor circuits, which allows for the construction of welding robots used at factories; at the sector level, the formation of automated welding lines emerges at different

\section{Figure 5. Expansion and Diffusion of a New Industrial Technology:} The Example of Electronically Controlled Welding

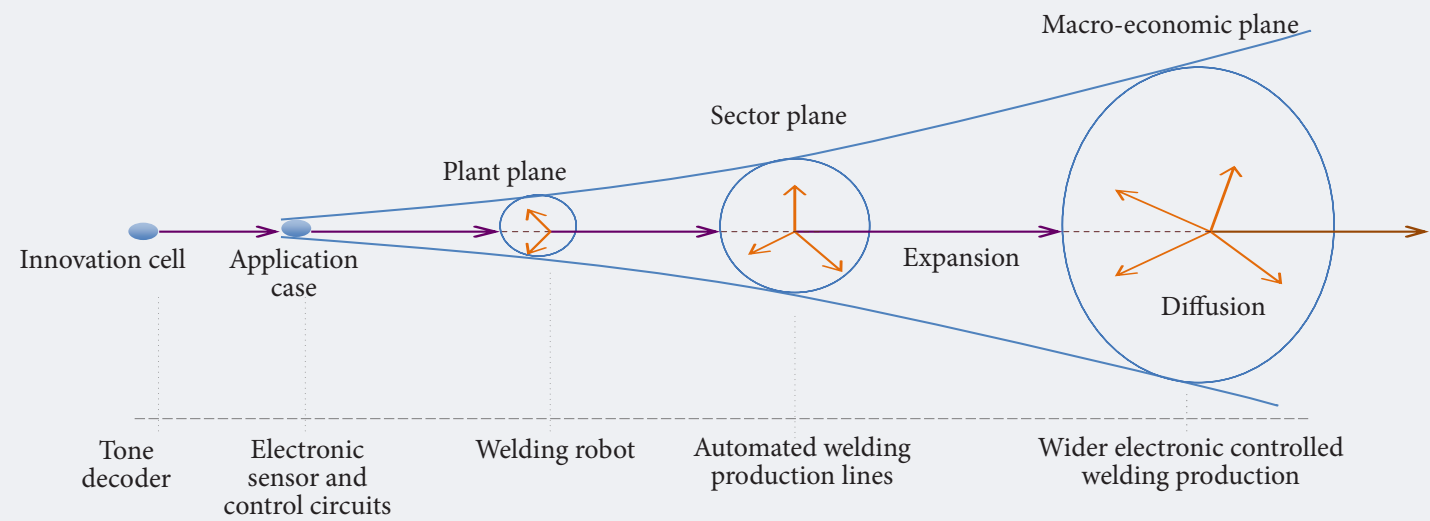

Source: compiled by the author.

\footnotetext{
${ }^{14}$ If it is possible to represent the consumption of a technology or product by a bell curve, one would observe that despite available new alternative technologies, some even obsolete technologies or products might have a long tail, being kept on the market for a longer period of time, thus delaying its substitution.
} 
production facilities; at the macro-economic level, is possible to identify a full range of industries using electronically controlled welding production.

The actual introduction of those technologies would create and/or destroy jobs, depending on the of efficiency and productivity they achieve in the frame of by a particular occupation. To characterize and eventually measure the complex process of technological advancement, one could propose a series of parameters that might influence the potential and reach of a new technology's impact upon employment. In general terms, such parameters affecting labour inputs can be represented as follows:

$$
L=f\left(\vec{v}_{\mathrm{D}}, \vec{v}_{\mathrm{E}}, P_{\mathrm{a}}, \psi, \nabla_{e f f}, \nabla_{p t}\right),
$$

$L$ - labour inputs; $\vec{v}_{\mathrm{D}}$ - velocity of diffusion; $\vec{v}_{\mathrm{E}}$ - velocity of expansion; $P$ a - probability of adoption/ application of a given technology in a corresponding plane; $\psi-$ pervasiveness of a given technology on a corresponding plane; $\nabla_{\text {eff }}$ - gradient of efficiency due to industrial application; $\nabla_{p t}-$ gradient of productivity due to industrial application

Foresight exercises' use of the parameters, variables, and indicators mentioned in this chapter could configure the reference models and algorithms capable of grasping the complex relationships between technological change, productivity, and efficiency. The present study considers technological change's relationship with employment at the micro level and the possible implications of it at the macro level. STI foresight basically deals with the processes and systems at the macro-level, eventually at the level of the sector or field of research.

\section{Evaluation of STI Foresight Exercises' Impact upon Employment}

In the case of Science, Technology and Innovation (STI) foresight exercises, the indirect effects of various policy and strategy measures upon labour markets are considered.

The approach to evaluating the impact of foresight exercises proposed here means to focus on the highest possible level of influence that might be achieved by a project or program. For that, it is necessary to identify feasible performance indicators, which can be measured using available or collectable data directly or indirectly related to the sphere of activity or system under consideration by the foresight study. Obviously, such indicators are not exclusively affected by the exercise itself, many factors and events could lead to other results. Moreover, the selected indicators should be appropriately sensitive to the political measures or strategies proposed by the foresight exercise.

To improve the quality of the evaluation work, the application of a logical framework is necessary and should be used throughout the entire foresight-strategic exercise: design, implementation, and evaluation, as stated in [Seidl da Fonseca, 2016].

In the case of STI foresight, the present paper proposes a group of impacts achievable by corresponding strategies and identifies feasible and adherent indicators. Such careful selection applies equally to the indicators of impact on employment. In the previous section, some methods and indicators for evaluating impact on employment were worked out.

Table 6 below compares the potential impacts of STI foresight exercises and their performance indicators with the possible impacts upon employment and its related indicators.

\section{Table 6. Elements for Evaluating of Impact of STI Foresight Exercises upon Employment}

\begin{tabular}{|c|c|c|c|}
\hline Impact of STI foresight exercises & Performance indicators & Impact on employment & Employment indicators \\
\hline $\begin{array}{l}\text { Enactment of new STI policies and } \\
\text { programmes }\end{array}$ & GERD & $\begin{array}{l}\text { Demand for new skills and } \\
\text { knowledge }\end{array}$ & Number of jobs at risk \\
\hline $\begin{array}{l}\text { Creation of joint-ventures and STI } \\
\text { agendas/new projects; consolidation } \\
\text { of research groups/institutions; } \\
\text { consolidation of STI capacities }\end{array}$ & $\begin{array}{l}\text { BERD } \\
\text { Number of technological } \\
\text { centers, R\&D and test } \\
\text { facilities }\end{array}$ & $\begin{array}{l}\text { Shifting capabilities and } \\
\text { skills }\end{array}$ & $\begin{array}{l}\text { Direct employment coefficient } \\
\text { Labour inputs }\end{array}$ \\
\hline $\begin{array}{l}\text { Emergence of social and technological } \\
\text { innovations }\end{array}$ & $\begin{array}{l}\text { Number of patent applications } \\
\text { Speed of obsolescence } \\
\text { Adoption, expansion and } \\
\text { diffusion of a new technology }\end{array}$ & $\begin{array}{l}\text { Technological } \\
\text { unemployment } \\
\text { Job expansion through the } \\
\text { capitalization effect }\end{array}$ & $\begin{array}{l}\text { Employment efficiency } \\
\text { Job susceptibility to new } \\
\text { technologies } \\
\text { Number of jobs at risk } \\
\text { Labour inputs }\end{array}$ \\
\hline $\begin{array}{l}\text { Raising competitiveness through } \\
\text { innovation }\end{array}$ & $\begin{array}{l}\text { Number of innovating } \\
\text { enterprises }\end{array}$ & $\begin{array}{l}\text { Technological } \\
\text { unemployment } \\
\text { Job expansion through the } \\
\text { capitalization effect }\end{array}$ & $\begin{array}{l}\text { Employment efficiency } \\
\text { Probability of computerization } \\
\text { Labour productivity }\end{array}$ \\
\hline $\begin{array}{l}\text { Influencing wider policy, strategy, } \\
\text { investment, program delivery, and } \\
\text { public attitudes }\end{array}$ & $\begin{array}{l}\text { HERD } \\
\text { Digital access index }\end{array}$ & $\begin{array}{l}\text { Changing job performance } \\
\text { evaluation }\end{array}$ & Labour productivity \\
\hline $\begin{array}{l}\text { Cultural changes towards longer-term } \\
\text { and systematic thinking and addressing } \\
\text { uncertainty }\end{array}$ & $\begin{array}{l}\text { Public knowledge about S\&T } \\
\text { through mass media }\end{array}$ & $\begin{array}{l}\text { Demand for new skills and } \\
\text { knowledge }\end{array}$ & $\begin{array}{l}\text { Employment efficiency } \\
\text { Labour productivity }\end{array}$ \\
\hline
\end{tabular}


Although STI foresight exercises in general cover a broad range of issues, given the importance and overarching influence of technology upon the development of employment, the set of indicators presented above can elucidate such effects.

\section{Conclusion}

The present paper proposes a methodology and measurement techniques for evaluating STI foresight and policy derived from such studies with relation to job creation or destruction.

The full range of parameters, variables, and indicators discussed in this paper could serve as an eventual standard for evaluating the results achieved by foresight exercises. The classification of the effects upon employment and the evaluation of their impact proved to be a challenging subject, requiring sources for theoretical concepts and empirical evidence. The work done here, by providing some new concepts and insights into the subject, is meant to serve as a research agenda on how to further establish effective and robust evaluation mechanisms for foresight in general.

\section{References}

Aghion P., Howitt P. (1994) Growth and Unemployment. The Review of Economic Studies, vol. 61, no 3, pp. 477-494.

Bacon R., Kojima M. (2011) Issues in estimating the employment generated by energy sector activities, Washington, D.C.: The World Bank.

BLS (2015) Employment Projections Program, Industry Employment and Output Projections to 2024 (Monthly labour Review, December 2015), Washington, D.C.: U.S. Bureau of labour Statistics. Available at: https://www.bls.gov/ $\mathrm{opub} / \mathrm{mlr} / 2015 /$ article/industry-employment-and-output-projections-to-2024.htm, accessed 24.11.2016.

Calvino F., Virgillito M.E. (2016) The Innovation-Employment Nexus: A Critical Survey of Theory and Empirics (ISI Growth Working Paper 9/2016), Paris: Sant'Anna School of Advanced Studies, Paris School of Economics, University Paris 1. Available at: http://www.isigrowth.eu/wp-content/uploads/2016/03/working_paper_2016_9. pdf, accessed 24.11.2016.

CES (2014) Future of Work: Jobs and Skills in 2030, London: UK Commission for Employment and Skills.

Cobb C.W., Douglas P.H. (1928) A Theory of Production. American Economic Review, vol. 18 (Supplement), pp. 139-165.

Frey C.B., Osborne M.A. (2013) The future of employment: How susceptible are jobs to computerisation?, Oxford, UK: University of Oxford.

Frey C.B., Osborne M. (2015) Technology at Work: The Future of Innovation and Employment, Oxford, UK: University of Oxford.

Havas A., Schartinger D., Weber M. (2010) The impact of foresight on innovation policy-making: Recent experiences and future perspectives. Research Evaluation, vol. 19, no 2, pp. 91-104. DOI: 10.3152/095820210X510133.

IBGE (1974) Matriz de Relações Interindustriais - Brasil 1970, Rio de Janeiro: Instituto Brasileiro de Geografia e Estatística (IBGE). Available at: http://biblioteca.ibge.gov.br/visualizacao/monografias/GEBIS\%20-\%20RJ/ matrizintersetoriais/Brasil_1970.pdf, accessed 24.11.2016.

Keynes J.M. (1936) The General Theory of Employment, Interest and Money, Cambridge, UK: Macmillan Cambridge University Press.

Leontief W. (1986) Input-Output Economics (2nd ed.), New York: Oxford University Press.

Mahroum S., Dachs B., Weber M. (2007) Trend spotting the future of information society technology human resources. International Journal of Foresight and Innovation Policy, vol. 3, no 2, pp. 169-186.

Martin B.R. (2010) Science Policy Research — Having an Impact on Policy? (Seminar Briefing no 7), London: Office of Health Economics.

OECD (1997) New Rationale and Approaches in Technology and Innovation Policy (STI Review no 22), Paris: OECD.

Seidl da Fonseca R. (1981) Förderung der Investitionsgueterindustrie als Impulsträger zur Industrialisierung von Entwicklungsregionen - Am Beispiel der Werkzeugmaschinenindustrie in Nordost Brasilien, München: Technische Universität München.

Seidl da Fonseca R. (2016) Impact Analysis of Foresight for STI Policy Formulation: Cases of Romania, Vietnam and Kazakhstan. Deploying Foresight for Policy and Strategy Makers. Creating Opportunities through Public Policies and Corporate Strategies in Science, Technology and Innovation (eds. L. Gokhberg, D. Meissner, A. Sokolov), Heidelberg: Springer International Publishing, pp. 197-225.

Seidl da Fonseca R., Saritas O. (2005) Instruments for Strategy and Policy: Modelling the Structure of the Policy-making on Science and Technology (Technology Paper Series, TPS 3/05), Vienna: United Nations Industrial Development Organisation (UNIDO).

UN (1979) United Nations Conference on Science and Technology for Development (Resolution No. 34/218 adopted by the General Assembly 19 December 1979), Vienna: United Nations. Available at: http://www.un-documents.net/ a34r218.htm, accessed 24.11.2016.

UN-ESCAP (1984) Technology for Development, Bangkok: United Nations Economic and Social Commission for Asia and the Pacific (UN ESCAP).

WEF (2016) The Future of Jobs - Employment, Skills and Workforce Strategy for the Forth Industrial Revolution. Global Challenge Insight Report. January 2016, Geneva: World Economic Forum.

Zeitlin J., Trubek D.M. (eds.) (2003) Governing Work and Welfare in a New Economy: European and American Experiments, Oxford, UK: Oxford University Press. 


\title{
Solo-Self-Employment, Human Capital and Hybrid Labour in the Gig Economy
}

\author{
Dieter Bögenhold \\ Professor, Department of Sociology, Dieter.Boegenhold@aau.at \\ Robert Klinglmair \\ Researcher, Department of Economics, Robert.Klinglmair@aau.at \\ Florian Kandutsch \\ Expert, Department of Economics, Florian.Kandutsch@aau.at
}

Alpen-Adria-Universitat Klagenfurt, Universitatsstrasse 65-67, 9020 Klagenfurt am Worthersee, Austria

\begin{abstract}
I
$\mathrm{n}$ the framework of changing contextual factors, this paper deals with one-person enterprises as the smallest units Lof entrepreneurial companies, which already represent more than $50 \%$ of Austrian companies. Within these microenterprises, a special group of self-employed can be identified at the blurred boundaries between dependent work and self-employment: the hybrid solo-self-employed, who are primarily operating as a sideline business. These hybrid forms enormously differ from regular entrepreneurs that
\end{abstract}

Abstract

\section{Keywords:}

structural change; labour market; gig economy; self-employment; entrepreneurship; hybridity; human capital perform their self-employment as their main business. Based on our own empirical survey, the paper aims to examine whether hybrid entrepreneurs are a homogeneous group or if differences exist with respect to their human capital. Our findings reveal several differences concerning for example, (dependent and self-employment) income, working hours, or one's main workplace. it can be summarized that education matters when looking at the different aspects of hybrid selfemployment activity.

Citation: Bögenhold D., Klinglmair R.,

Kandutsch F. (2017) Solo Self-Employment, Human Capital and Hybrid Labour in the Gig Economy. Foresight and STI Governance, vol. 11, no 4, pp. 23-32. DOI: 10.17323/2500-2597.2017.4.23.32 


\section{Introduction: Change as the only Constant}

The philosopher Heraclitus of Ephesus was right. Centuries before the start of our modern Christian computation of time, he claimed that everything is changing and nothing stands still. Speaking of capitalistic societies, Joseph Alois Schumpeter stated that capitalism must be seen as an evolutionary process, which, by its nature, never can be stationary [Schumpeter, 1942]. Societies are in a process of flow. They are constantly changing as time passes due to the 'products' of the society in a given period of time. Nowadays, of course, things are also changing. A technological revolution centered on information and communication technologies has reshaped and is still reshaping the fundamental basis of our society.

So, as time marches on, the institutional settings of societies are in the process of transition altering the foundations of the very same societies. Nowadays, this transition is accelerating from period to period due to major achievements in modern information and communication technologies. As labour markets are closely linked to the characteristics of societies, they are also facing massive structural changes, which affect the composition of the labour markets and, in particular, the self-employed part thereof. One section of the paper will take a closer look at the changing contextual factors with a focus on the implications for the labour market, in particular for the (solo) self-employed. This paper deals with a special group within the sector of self-employment, which is receiving increasing interest from scholars in that field: the hybrid (solo) self-employed. Within this group, we are facing great heterogeneity with respect to different aspects and we can see a rise of blurred boundaries between dependent work and self-employment. The majority of the self-employed are working as a one-man- or one-woman-firm, which raises the need for challenging established views on self-employment and entrepreneurship. Why it is useful to engage in a discussion about the stereotypical views of the self-employed or entrepreneurs will be an important topic with which this paper deals.

The overall aim of this paper is to examine the differences within the special group of solo-self-employed persons belonging to the hybrid category. A special focus in this paper lies on differences with regard to their educational background. Based on our own empirical study, the findings reveal that there are differences with respect to the different educational levels. The empirical part of the paper takes up several of these findings and tries to discuss them within the framework of the great heterogeneity that underlies this group. As a starting point for our discussion, the first part of this paper focuses on the development of self-employment in the 20th century.

\section{Decline, Stabilization and Rise of Self-employment}

The 20th century was the century of the establishment of contractual labour in the modern form, where wage- or salary-dependent work was typical for the great majority of people in the employment system. People are formally free entities who can enter into contracts on the basis of existing rules set down by labour laws, although this freedom was limited through the power of supply and demand on the labour market. If the individual has no alternative other than to accept a specific contract offer, actual freedom is fairly limited because the choices are limited. The establishment of rationality within such a contractual society is portrayed in Max Weber's reflections on the sociology of law [Weber, 1978]. The 'iron cage' [Weber, 2003] is based upon technological efficiency, control, and rational calculation and can also be described, in the words of George Ritzer [Ritzer, 1993], as the McDonaldization of society. Hand in hand with the rise of industrial capitalism and the establishment of the historically new contract system including labour laws, social security, and welfare rights, went the rise of mass production.

In parallel with the rise of mass production, modern societies experienced a general decline of selfemployment within nearly all OECD countries over the course of the 20th century. Much of this decline goes back to the decline of employment in the agricultural sector due to the enormous increases of productivity achieved in the sector. Research on institutional factors [Acs et al., 1992; Staber, Bögenhold, 1993] indicated a variety of components, which influenced the ratios of self-employment. Specifically, the relative ratios of unemployment remain in direct connection with self-employment ratios. Crossnational research for a series of different OECD countries showed that an upsurge in unemployment was always responsible for an upswing in self-employment ratios for a time span of several decades [Bögenhold, Staber, 1991].

The historical decline of self-employment has come to a relative standstill, or self-employment has even been experiencing a slight revival since the 1980s, although different countries show different patterns of concrete development. For a series of selected OECD countries within an observation period of 1955-2015, Figure 1 indicates that the direction of development coincided between most of the countries although the relative levels of departure and change differ.

Looking at self-employment, ratios show a specific level of self-employment within a specific time, but this view hides the fact of inter- and intragenerational social mobility behind the figures. The figure may remain the same, while at the same time multiple inflow and outflow dynamics are taking place. Sociological stratification and mobility research shows the high dynamics between wage dependent work and unemployment on the one hand and self-employment on the other. In other words, self-employment as a category continuously receives fresh blood and loses old blood through 'underground mobility'. labour market dynamics and social mobility patterns are of great interest to researchers focusing on the division of occupations and related dynamics in the economy [Arum, Müller, 2004].

Empirically divergent paths and the logic of people moving towards self-employment must be taken into account so that not only one typical manner of recruitment is visible, but several different types, each with a competing social logic. In contrast to stereotypical assumptions, the phenomenon of self-employment may look entirely different when it is studied as a phenomenon embedded in labour markets and specific occupational contexts, applications, and sectors. Some types of small businesspeople and independent 
Figure 1. Ratios of Self-Employment in OECD countries from 1955-2015(\%)

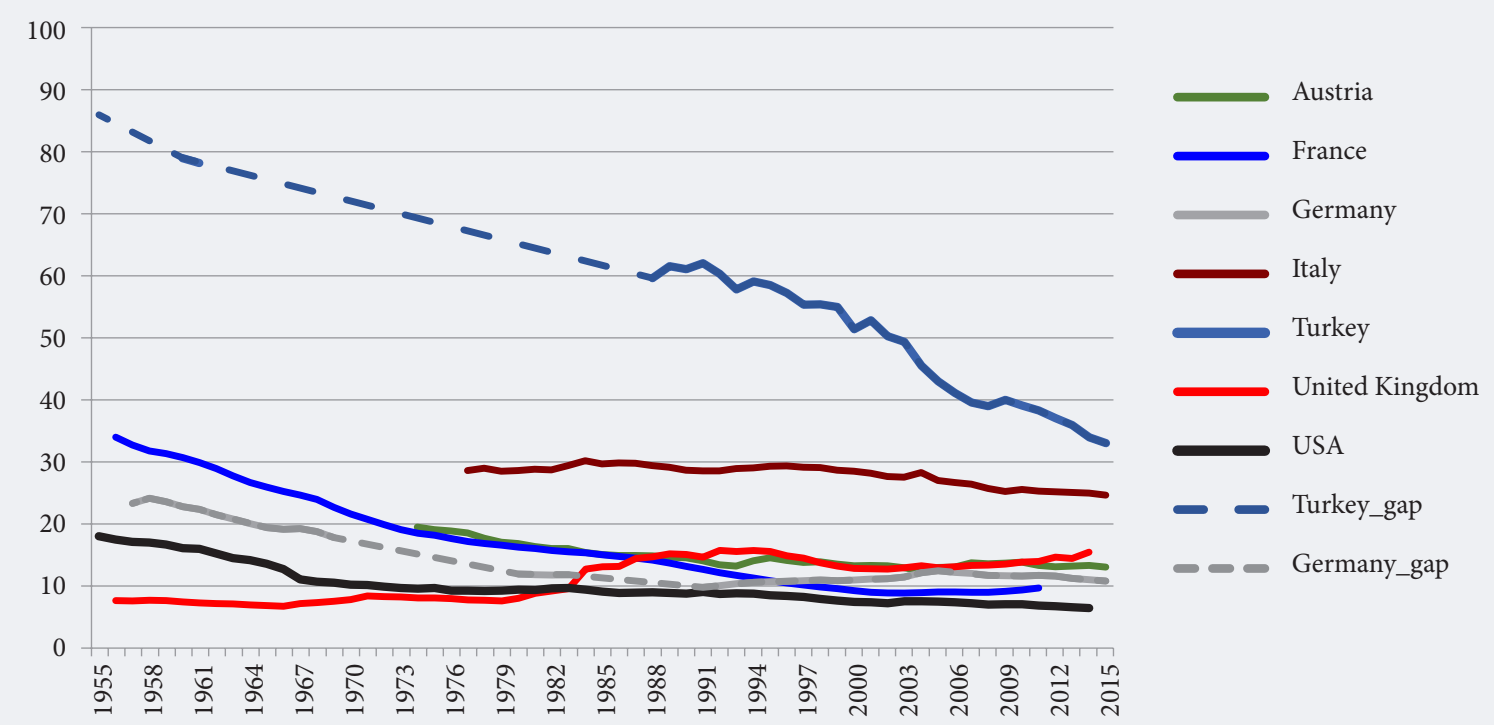

Source: compiled by the authors based on [OECD, 2017].

professionals belong to a category that does not fit with the image of entrepreneurship [Burke, 2011; Burke, Cowling, 2015]. They do not show ambitions for growth and they operate in routines, which are sometimes very close to low income ranges, occasionally to poverty [Shane, Venkataraman, 2000]. Empirical studies on the diverse groups of self-employed individuals in larger societal and labour market contexts may produce alternative pictures, challenging stereotypical assumptions and the types of rhetoric related to self-employment and independent business [Blackburn, Kovalainen, 2008; Kautonen et al., 2010; Bögenhold, Fachinger, 2013; Cieslik, 2015; van Stel, de Vries, 2015].

\section{Digitalization and the Gig Economy: Changing Contextual Factors}

Behind the regular development of the rises and falls in self-employment, one has to acknowledge global trends towards a decline in employment in agriculture and the de-industrialization of economies and societies, which leads to the increasing weight of employment in the tertiary sector. According to OECD data on labour force statistics [OECD, 2015], nowadays between $75 \%$ and $85 \%$ of the total labour force is engaged in work in the tertiary sector, whereas in the middle of the 20 th century only between $30 \%$ and $45 \%$ of the labour force was located there. According to this, the vast majority of people in the employment system is no longer engaged in manufacturing or primary production, but is associated with some kind of post-industrial production [Bell, 1973]. Of course, even the tertiary sector is very widespread and Bell [Bell, 1973, chapter 1] added a quaternary (trade, finance, insurance, real estate) and quinary sector (health, education, research, government, recreation) in order to highlight the different segments of the so-called post-industrial society. In the historical timeframe encompassing the last century, if not centuries, we can see a decisive change of the social landscape of human life. Among other historically significant developments, those of particular interest are centered around innovations regarding information technologies and have constituted a new technological paradigm. These innovations have reshaped and still are reshaping our society and everything that is part of it [Mokyr, 2002; Jin, 2016]. Due to the fact that we are living in a capitalistic society, which is characterized by constant movement [Schumpeter, 1942], we are always facing transitions. However, the remarkable point nowadays is the pace with which this overhauling process of the capitalistic system itself can be observed. One of the earliest and most central insights of economic science was that continuous development involves structural change [McCloskey, 2010]. Besides many other important implications caused by this general overhauling, the changing structure of the labour market is of particular interest [Castells, 2010].

The digitalization of economic activities and the emergence of newly networked enterprise units resulted in the shortening of the time period per operation and the acceleration of the turnover of resources. New management techniques have changed and increased the speed of financial transactions to hours, minutes and seconds due to the availability of new information technologies, with which well-defined software and programs can generate losses or gains by quasi-instantaneous decisions [Jin, 2016]. What truly matters for every social process and form is the actual interaction between the modes of development and the modes of production ('the living flesh of societies') enacted by social actors in often unpredictable ways within a framework of past history and current conditions of technological and economic development surrounded by great uncertainty [Mokyr, 2002; McCloskey, 2010].

The most decisive factor (historically) accelerating, channelling, and shaping the information technology paradigm was the process of capital restructuring, which has been undertaken since the 1980s. This process led, in a nutshell, to a series of reforms (the deregulation, privatization and dismantling of the social contract between labour and capital). Four goals were pursued: (1) deepening the capitalist logic of profit-seeking in 
capital-labor relationships, (2) enhancing the productivity of labour and capital, (3) globalizing production, seizing the opportunity of the most advantageous conditions for production, and (4) marshalling the state's support for productivity gains and the competitiveness of economies. Without the new information technology, the capitalist restructuring would have been much slower, with much less flexibility [Castells, 2010]. When we speak of the 'information society' and the new semantic of a 'gig economy', we have to acknowledge that these societies are capitalist societies and that they always experience some degree of cultural and institutional diversity.

The shift to a tertiary, quaternary, and quinary economy went hand-in-hand with the transformation of the structure of occupations, educational profiles and the division of firms. The fourth logistical revolution brought new competitive factors [Andersson, Andersson, 2017] including new communication networks, cognitive skills, creativity in scientific research and R\&D, complexity of goods/services, and new forms of education, further education, and work training. Deming [Deming, 2015] shows, for the United States, the change of required job skills in the period from 1980 to 2012, when the component of social and mathematical skills had increased in different compositions but did so steadily.

When we discuss the level, quantity, and quality of recent work profiles we must also take into account that new phenomena are appearing due to the new technological opportunities in the gigeconomy, first of all, crowdwork and 'work on demand via apps'. Crowdwork is work that is "executed through online platforms that put in contact an indefinite number of organizations, businesses, and individuals through the internet, potentially allowing for connecting clients and workers on a global basis" ... while 'work-on-demand' via apps refers to "jobs related to traditional working activities such as transport, cleaning, and running errands, but also forms of clerical work, are offered and assigned through mobile apps" [de Stefano, 2015]. Of course, the last group is not homogeneous and the most relevant distinction can be drawn between apps that match demand and supply of different activities such as cleaning, running errands, home-repairs and other apps that offer more specialized service such as driving, or even some forms of clerical work such as legal services or consultancy [de Stefano, 2015, pp. 2-3; Aloisi, 2015].

\section{Solo-Self-Employment as an Independent Case Study}

Contextualizing the object of investigation [Welter, 2011] implies acknowledging that the shift to the service sector in general, and to digitalization in particular, fosters a relative move towards increasingly smaller units of self-employment [Cieslik, 2017]. Especially when talking about the organization of firms, many contemporaries forget that the vast majority of firms consist of small and medium-sized units. Additionally, among these, most belong to the category of the smallest firms, where the owner operates as a one-man or one-woman firm, where the owner is synonymous with the firm and vice versa [Wynn, 2016]. Furthermore, many freelancers are located in this group, where they are statistically not always counted as firms, but belong to the group of self-employed occupations.

As Table 1 indicates, the share of solo-self-employed people is remarkably high with regard to the total amount of self-employed persons. In this table, only a few member states were picked to show the relevance of the solo-self-employed, but it should be stated here that no country within the EU has a share below the $50 \%$ mark, while the average for the European Union is even higher than $70 \%$.

Interpreting new markets as a complex result of occupational changes at the macro level and social mobility within the biographies of individual agents, gives one an idea of how changes serve as sources of newness and innovation. The existence of new and, at least initially, small firms is nurtured above all else by the shift in the economy towards the service sector [Castells, 2010]. First of all, new occupations and job profiles are emerging. These are then in turn associated with the emergence of a multiplicity of new selfemployed occupations and job profiles. The significance of growth in professional services for the future of self-employed activity is revealed by a look at the trend in those occupations, which belong primarily to the segments of business services and education, health and culture. Principle changes in society provide a basic foundation for new areas of independent, liberal professions as well as for new firms in the service

Table 1. The Share of Solo-Self-Employed Persons in Selected EU Member States

\begin{tabular}{|l|c|}
\hline EU country & \% \\
\hline EU average & $\mathbf{7 1 . 4 4}$ \\
\hline Romania & 93.45 \\
\hline United Kingdom & 83.40 \\
\hline Lithuania & 79.33 \\
\hline Czech Republic & 78.95 \\
\hline Netherlands & 75.32 \\
\hline Italy & 71.77 \\
\hline Spain & 70.72 \\
\hline France & 61.38 \\
\hline Austria & 59.88 \\
\hline Germany & 54.75 \\
\hline Source: compiled by the authors based on [Eurostat, 2016a]. & \\
\hline
\end{tabular}


sector, especially when the so-called creative industries [Florida, 2002; Flew, 2012] also became a domain of professional expertise and when trends of globalization and company strategies of outsourcing interact [Oshri et al., 2008; Bharat, 2012].

Due to the increased recent trends and related flexibility and uncertainties, people show up in the cloak of self-employment who are sometimes just de facto laborers without social security benefits [Kalleberg, 2011]. On the other hand, due to general changes in lifestyles and values, an increasing number of freelancers are emerging, who just want to work on their own without being involved in hierarchies [Hytti, 2005], not solely, but often, in the growing IT sector [Shevchuk, Strebkov, 2015]. Independent liberal professions are definitely not regarded as 'core entrepreneurs'. Bögenhold et al. [Bögenhold et al., 2014] have shown that even between the various groups of freelancers in Finland, sometimes huge differences in labour market behavior and attitudes exist (for the context in the UK, see [Burke, 2011; Kitching, Smallbone, 2012]). Some types of small businesspersons and independent professionals belong to a category that does not fit with the traditional image of entrepreneurs as risk-takers and innovators. They do not show ambition for growth and they are sometimes very close to the low income ranges, occasionally even to poverty [Bögenhold, Fachinger, 2016]. Empirical studies on diverse groups of self-employed individuals in larger societal and labour market contexts produce alternative pictures that challenge stereotypical assumptions and rhetoric related to entrepreneurship. They highlight the heterogeneity of the occupational category of self-employment.

Findings reveal that the life and work situation of self-employed and liberal professions cannot be interpreted in simple black and white schemes, such as 'close to poverty' and pushed by missing employment opportunities into the sector of work for wages on the one hand versus working without hierarchies and being independent and self-realized on the other. Instead, many different socioeconomic situations can be found 'in between', which are driven by differing social approaches. However, looking at the margins of the economy contributes to challenging some stereotypes about self-employment or entrepreneurship [Friedman, 2014]. McKeown [McKeown, 2016] has shown that the actors are often not entirely certain about their own classification. Their self-definition oscillates between entrepreneur, self-employed person, consultant, independent professional (I-pro), or simply contractor. It is not always clear, if we have to speak about a professional contractor or an independent professional [Johal, Anastasi, 2015]. Self-employment is very often a biographical period and takes the form of being a social process within the course of one's lifetime [Mayer, 2009; Kohli, 2007].

Being part of a so-called entrepreneurial society [Audretsch, 2007] must be furnished sociologically: in doing so, we also have to acknowledge a variety of 'non-standard' forms of self-employment, including part-time self-employment, self-employment just for brief periods, freelancers, and other different sectoral activities (such as, e.g., farmers).

Full-time working freelancers, farmers, micro-entrepreneurs without employees, and 'big' entrepreneurs employing a larger share of wage- or salary-dependent employees are difficult to summarize in one single box. The black and white dichotomy of being dependent or self-employed seems to neglect the multiplicity of inflow and outflow processes, which take place constantly behind the aggregate figure and which are very often related to complex processes of individual attempts to increase one's social status. Therefore, those new forms of self-employment are difficult to define, since parts are pushed out of necessity while others are pulled and a sign of choice; parts belong to the new gig economy, while others work in relatively traditional sectors [McKinsey, 2016]. Last, but not least, we are experiencing the phenomenon that people fall into more than one box, they are self-employed and wage- or salary-dependent employees simultaneously.

When dependent workers and independent actors sometimes have overlapping identities, we may call them hybrid entrepreneurs [Folta, 2007; Folta et al., 2010; Raffiee, Feng, 2014; Schulz et al., 2016]. While 'die-hard entrepreneurs' [Burke et al., 2008] are those actors, who are primarily portrayed in public discourse and in economic literature, namely those actors who are dynamic, willing to expand and to take risks, hybrid (self-employed) laborers seem to be of a different nature. This empirical study will further discuss those hybrid forms of self-employment. Specifically, following our own previous empirical findings, we will explore whether or not qualification matters when dealing with positive or negative aspects of hybrid selfemployment.

\section{Empirical Findings on Hybrid Self-Employment: Does Human Capital Matter?}

In Austria, the category of solo-entrepreneurs accounts for $59.9 \%$ of all self-employed according to the Eurostat Database [Eurostat, 2016a, b]. The share of solo-entrepreneurs within total self-employment in the EU-28, by contrast, accounts for $71.5 \%$. Even though Austria is below the EU-28 average, we can see the importance of micro enterprises without employees, which account for far more than the half of all selfemployed people. Moreover, Austrian statistics indicates the significant relevance of enterprises led by one man or woman. The Austrian public census of company units shows that 322,889 firms are led by a solo entrepreneur, representing 61.8\% of all firms located in Austria [Statistik Austria, 2015]. A lower level of solo-self-employed is presented by the Austrian Chamber of Commerce ('Wirtschaftskammer Österreich'; WKO). This is caused by the exclusion of a variety of types of freelancers, who do not have to be registered at the chamber. WKO data show the share of one-person-enterprises, compared with the total number of enterprises registered, which amounts to 58.9\%. In absolute figures, the WKO counts 290,061 units of solo-self-employed persons in the whole of Austria. Compared with the previous year, the figure of soloself-employed people has risen by $4.2 \%$. If we look at the federal state of Carinthia, which is of interest in our empirical section, 18,097 one-person-enterprises are listed in the register of the Austrian Chamber of Commerce. The share of microenterprises without further employees amounts to 57.3\% for Carinthia, which is slightly below the Austrian average. More than $60 \%$ of all solo firms have their domains in the business and creative sectors, as well as in the information and consulting sectors. Also, the trade sector, with a share of $48.5 \%$, has a high number of solo firms [Wirtschaftskammer Österreich, 2015]. 
After the evaluation of data from official European and Austrian statistics, we can see that one-personenterprises play a very important role in the European and Austrian business sector, since they make up the majority of enterprises. However, there is a lack of information about the group of hybrid-entrepreneurs. The group of hybrids are those firms where the owner is involved in more than one activity. The question we raise is how the education of those hybrid-entrepreneurs accounts for the emerging differences. Are there serious differences within this group, if we look at the educational background and if yes, where do they emerge? In order to answer the questions, a broad online survey was implemented in cooperation with the Carinthian Chamber of Commerce. The survey is based on a questionnaire containing 52 questions in total. The questionnaire was developed and tested in a long process lasting several months. It was finally adapted with the help of LimeSurvey. The questionnaire contains questions about the motives behind selfemployment, client relations, success and satisfaction with self-employment, future prospects of the soloself-employed, and socioeconomic characteristics.

A total of 9,002 one-person enterprises were contacted by the Carinthian Chamber of Commerce in February 2014 and invited to participate in an online survey. The response rate of $7.0 \%$ resulted in a sample size of 626 one-person-enterprises, which is representative with respect to the legal form (over $90 \%$ of the sample comprised individual entrepreneurs), age (mean age in the sample and in the total population: 47 years), and gender, with males being slightly overrepresented in the sample compared with the total population. Several findings of the study are published in more detail elsewhere [Bögenhold, Klinglmair, 2014, 2015a, 2015b, 2016a, 2016b, 2016c; Klinglmair, Bögenhold, 2014].

The complex interaction between technological development, globalization and socio-demographic change has accelerated the structural change of the economy resulting in a changing working environment and new forms of employment. Concerning the field of self-employment, in many countries an emerging trend can be observed towards one-person enterprises, which, for example, already represent more than $50 \%$ of all Austrian companies as described above. One clearly has to keep in mind that these microenterprises are by far not homogeneous in a variety of aspects like motives for self-employment [Bögenhold, Klinglmair, 2015a, 2015b] or by gender on the one hand, and by the extent of additional economic activities [Bögenhold, Klinglmair, 2016a, 2016b, 2016c] on the other. For instance, we found evidence that one-person entrepreneurs are mainly driven by motives such as self-realization or working without hierarchies [Bögenhold, Klinglmair, 2015a]. However, there is also a large group of self-employed (25.2\%) that has been crowded out of the (dependent) labour market. These one-person entrepreneurs decided to start their business due to labour market reasons and are therefore driven by economic reasons; thus, self-employment primarily represents an alternative to unemployment. Moreover, this economically driven group of one-person enterprises is relatively dissatisfied with their professional situation, is less optimistic regarding their entrepreneurial future, and generates lower incomes [Bögenhold, Klinglmair, 2015a, p. 107]. Blurred boundaries between dependent work and self-employment exist. These boundaries are fluid and dynamic in their nature and do not fit with the idea of a clean division that separates the sphere of dependent work neatly from that of independent work. These overlapping phenomena, when people combine both categories and dependent workers as well as independent actors, have overlapping identities [Bögenhold, Klinglmair, 2016a, 2016b, 2016c] and are very often neglected in the research and are addressed in this paper.

In the collected (and described) data sample, beside 398 one-person enterprises (63.6\%) that are solely selfemployed and perform no additional activities, another $18.5 \%$ (or 116 one-person enterprises) that have an additional dependent employment beside their business have been identified; this group can be described as 'hybrid' entrepreneurs. We investigated whether this additional dependent employment represents a necessity-driven secondary job to survive economically, or whether the one-person enterprise, namely the self-employment activity, represents only a secondary source of income [Bögenhold, Klinglmair, 2016a]. Based on five indicators (e.g., monthly net income from dependent employment; for details see [Bögenhold, Klinglmair, 2016a, p. 133]) we identified that more than half of the hybrid one-person enterprises (53.3\%) only operate as a sideline business; self-employment activity indeed represents only a secondary source of income [Bögenhold, Klinglmair, 2016a, p. 136]. Moreover, hybrid self-employment significantly differs from non-hybrid 'regular' entrepreneurs with respect to socio-demographic characteristics as well as professional and company-specific factors [Bögenhold, Klinglmair, 2016c]. For example, the group of regular entrepreneurs primarily works at their own office compared to hybrid forms of entrepreneurship, which are operated as a sideline business mainly at home. In addition, hybrid entrepreneurs significantly focus more often on regional customers and markets. Furthermore, hybrid entrepreneurs are significantly younger (43.6 vs. 48.0 years on average), their businesses exist for shorter periods of time than regular oneperson enterprises (6.9 vs. 9.5 years on average) and they have lower annual turnover, and, respectively, a lower monthly income from self-employment due to the fact that they spend less working time on their business and conversely earn more from the (primarily full-time) dependent employment; for more details see [Bögenhold, Klinglmair, 2016c, pp. 8-10]).

Using a logistic regression model, we additionally investigated several factors that determine the probability of the occurrence of hybrid entrepreneurship [Bögenhold, Klinglmair, 2016b]. Beside age, the situation in which the one-person enterprise was founded, the duration of the enterprise, as well as the motives for being self-employed, two important determinants were identified. First, the family background does not play a significant role for explaining hybrid self-employment. The presence of a working partner did not turn out to be a statistically significant influencing factor. This result may be caused by the fact that the additional dependent employment is in most cases not necessity-driven [Bögenhold, Klinglmair, 2016b, p. 15]. Second, one-person enterprises where the person has a tertiary education are more likely to be additionally (dependently) employed compared to their less educated counterparts. This result may also be motivated by the preferable situation of academics on the (regular) labour market. In figures, one-person enterprises with a tertiary education are, all else being equal, about twice as likely to be employed alongside their business activities than less educated hybrid entrepreneurs [Bögenhold, Klinglmair, 2016b, p. 16]. 
Figure 2. Monthly Net Income from Additional Dependent Employment (\%)

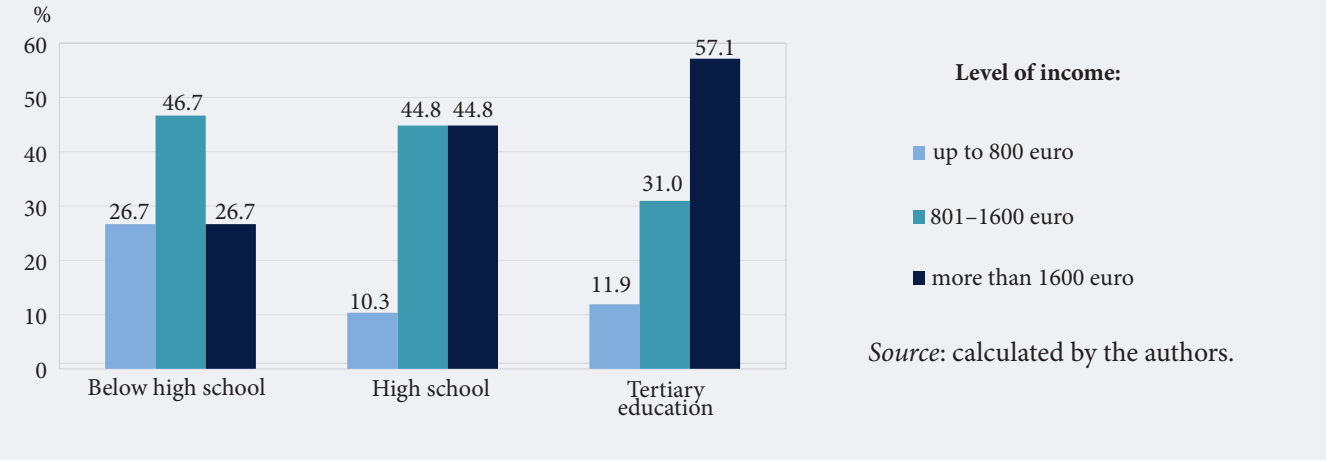

This can, on the other hand, also be reflected by the fact that hybrid one-person enterprises are significantly better educated in the collected data sample, as more than one-third (36.2\%, 42 persons) has completed a tertiary education, while this applies to only $24.7 \%$ (126 persons) of the non-hybrid entrepreneurs. Conversely, the share of solo-entrepreneurs with an educational level below high school is significantly lower within the group of the hybrid self-employed (38.8\% or 45 persons vs. $49.6 \%$ or 253 persons). ${ }^{1}$ In summary, we can conclude the following: (1) a large share of one-person enterprises in Carinthia are forms of hybrid entrepreneurs that operate their business as sideline business and (2) these hybrid forms differ enormously from regular entrepreneurs that represent their self-employment as their main business. What remains open is whether hybrid entrepreneurs can be treated as a homogenous group or if they also differ by selected characteristics, where we especially focus on the educational level in the sense of 'whether human capital matters. Are there differences in the amount of the self-employed and/or dependent sources of incomes by educational level and do more highly educated groups achieve higher individual returns on education? What about satisfaction with one's professional career? Can the hybrid solo-self-employed be divided into two groups, namely opportunity-driven and necessity-driven entrepreneurs based on their human capital? These and more questions will be addressed in the following empirical analysis of our data sample.

With respect to the monthly net income from additional dependent employment it can be shown that more highly educated hybrid entrepreneurs (tertiary education level) receive 'returns on education' on the dependent labour market as expected by the human capital theory: the higher the educational level, the higher the dependent income (see Figure 2); this effect is statistically significant based on a contingency table analysis (Pearson- $\chi 2=10.15 ; p=0.038){ }^{2}$ In detail, a share of $57.1 \%$ of hybrid entrepreneurs with tertiary education has a monthly net income above $€ 1,600$; in contrast, only about one-eighth (11.9\%) realizes a dependent net income below $€ 800$. For solo-self-employed persons with educational levels below high school the opposite results can be obtained: a share of only $26.7 \%$ ranges in the highest income category, while more than one fourth earns less than $€ 800$ per month; the majority (46.7\%) earns between $€ 800$ and $€ 1,600$ a month. A similar relationship is observed for medium qualified solo-self-employed (with a high school degree): a share of only $10.3 \%$ earns a monthly net income below $€ 800$; the remaining $89.7 \%$ are allocated equally in the two higher income categories.

Before the analysis is expanded additionally to the relationship between monthly net-income from selfemployment and the acquired human capital, two facts concerning the general low income levels of the hybrid solo-self-employed compared to non-hybrid entrepreneurs (€608 monthly net income on average vs. $€ 1,347$ for non-hybrid entrepreneurs) should be considered. First, hybrid entrepreneurs mainly operate their business as a sideline business, as already described by [Bögenhold, Klinglmair, 2016a, p. 136]); self-employment activity therefore often only represents an additional source of income. Second, the professional fields in which the respondents operate their business generally do not represent the vocational background of the particular entrepreneur as the Kruskal-Wallis Test, an extension of the Mann-Whitney-U Test for more than two groups, shows $(\chi 2(2)=8.89 ; p=0.012)$. Learned skills based on the formal educational background and/or professional experience, respectively, tenure for dependent employment cannot be individually assigned to self-employment activities.

Moreover, a similar effect between self-employment salaries and the educational level, as has been identified for dependent income, cannot be directly observed. For this purpose, the monthly net income was aggregated into two categories; income category 1 with salaries below $€ 1,000$ per month and category 2 with income levels above $€ 1,000$. While hybrid entrepreneurs with a high school degree are located between the two categories as expected, it can be shown that more qualified hybrid entrepreneurs (tertiary education) are slightly overrepresented in category 2 compared to those solo-self-employed without a secondary education. However, these differences are too small and statistically insignificant. The income from selfemployment is therefore independent from the educational level in the collected data sample based on

\footnotetext{
The share of persons with a high school degree amounts to $25.0 \%$ (29 persons) among hybrid entrepre-neurs and $25.7 \%$ (131 persons) for non-hybrid self-employed, respectively.

This result is independent from weekly working hours based on a contingency table analysis; there are no statistically significant differences in working hours by educational level (Pearson- $\chi 2=6.83 ; \mathrm{p}=0.337)$, higher income levels do not therefore result from higher weekly working hours.
} 
a contingency table analysis (Pearson- $\chi 2=3.46 ; p=0.177$ ). Nevertheless, what immediately stands out is that although no significant education-dependent differences in salaries can be identified weekly working hours differ by educational background on a $10 \%$-significance-level (Pearson- $\chi 2=20.83$; $p=0.053$ ). While entrepreneurs with tertiary education are overrepresented in the categories with low(er) working hours (less than 30 hours/weekly), this group is underrepresented in the category with more than 60 hours per week. These findings contradict those for hybrid entrepreneurs with an education level below high school; for instance, this group is overrepresented in the category with 60 hours and above. Hence, if we consider selfemployment income per hour (instead of monthly salary) the relationship between income and educational achievement can be at least observed indirectly for self-employment sources of income as well.

Furthermore, concerning the distribution between industrial sectors of one-person enterprises it was found that differences with respect to sectors between hybrid and non-hybrid solo-self-employed are not statistically significant [Bögenhold, Klinglmair, 2016c, p. 851]. Conversely, if we consider only hybrid soloself-employed and differentiate the business sectors where the hybrid entrepreneurs operate by educational status, significant results based on a contingency table analysis arise. Solo-self-employed with a tertiary education (as well as the group of hybrids with a high school degree) operate in a significantly higher number in prosperous branches such as the manufacturing sector or the information and communications (ICT) branch, while the opposite is true for persons with educational levels below high school. The group of the lowest qualified solo-self-employed perform their businesses to a comparatively higher extent in the trade or tourism sectors and are, conversely, underrepresented in the manufacturing and ICT sectors (Pearson $-\chi 2=26.06 ; p=0.011)$.

Focusing further on the regional distribution of enterprises the data show that medium and high qualified solo-self-employed operate their business primarily in the Carinthian central area (Klagenfurt-Villach), while entrepreneurs without a high school education do their business to a higher extent in Carinthia's rural regions; these differences are significant at a $10 \%$-significance level based on a contingency table analysis (Pearson- $\chi 2=28.21 ; p=0.059)$. Additionally, significant differences concerning the main workplace - again at a $10 \%$-significance-level - arise by qualification status (Pearson- $\chi 2=13.99 ; p=0.082$ ). While, for example, $82.2 \%$ of solo-self-employed firms without a high school degree operate their businesses at home ('home office') or directly at the customers' premises, this is true for a comparatively lower share, $69.0 \%$, of hybrid entrepreneurs with a tertiary education. In contrast, the lowest qualified group is underrepresented in the category 'one's own office' or 'co-working spaces (13.3\% with a lower education vs. $23.8 \%$ of the highly qualified solo-self-employed). For the lowest qualified solo-firms with significantly lower dependent income levels and lower entrepreneurial salaries, operating one's own office or co-working space seems to be unprofitable. Combined with the fact that this group performs their business in rural regions, long(er) distances directly to the customers and thus (transport) costs rise for this already disadvantaged group. Nonetheless, the identified lower (dependent as well as self-employed) incomes and the higher amount of weekly working hours for the more lowly qualified compared to medium and highly qualified solo-selfemployed entrepreneurs have no significant influence on job satisfaction or the satisfaction with one's 'work-life balance' based on two separate Kruskal-Wallis Tests $(\chi 2(2)=0.15 ; p=0.928$ for job satisfaction and $\chi 2(2)=1.02 ; p=0.600$ for satisfaction with one's work-life balance).

With respect to the empirical findings above, it can be concluded that there are two major groups within the examined hybrid solo-self-employed. On the one hand, we have those (highly qualified) actors who pursue an additional job because they see an opportunity to maximize their income, on the other hand there are actors who have to pursue an additional job to compensate for the lower income they receive from their dependent employment arrangement ('necessity-driven'). In other words, we can summarize that we find opportunity-driven entrepreneurs as well as necessity-driven entrepreneurs within the specific group of hybrid solo firms. Although the hybrid solo-self-employed belong to either the first or the latter category, no difference with respect to their job satisfaction can be found. This reflects that fact that necessity-driven entrepreneurs know, at the end of the day, that they have to engage in an additional profession beside their low paid dependent employment to make ends meet, but they accept these circumstances. Similar studies (and results) on the educational background differentiating between opportunity-driven and necessitydriven self-employment have already been conducted (e.g., [Baptista et al., 2013]), but there is much room for further research, in particular with a focus on the hybrid solo-self-employed.

\section{Conclusions and Outlook}

As the 'rules of the game' [Baumol, 1990] change, we have to pay attention to the changing character of selfemployment. Different countries have different specific institutional settings, making it almost impossible to generalize self-employment. Contextual views are necessary to grasp the diversity in self-employment, therefore an acknowledgement of the historical, temporal, institutional, and social contexts is unavoidable [Welter, 2011]. The implication is that we have to respect the different forms of self-employment when talking abstractly about the category of self-employment on the labour market, too diverse are the social, economic and cultural conditions and related biographies. Among the heterogeneity of actors under the umbrella of self-employment the empirical focus of this paper concentrated on the one-(wo)man firms, which are, in other words, self-employed people without further employees. Here, more specifically, we asked about those solo-self-employed who have further sources of income as dependent laborers. This group is most commonly called hybrid self-employment.

Hybrid self-employed actors are difficult to locate exactly between the boundaries of the employee and the self-employed. The two forms of hybrid self-employed are classified as: (1) self-employed having an additional dependent employment relationship to maximize their income and vice versa (2) people having a dependent employment relationship who pursue a form of self-employment to ensure additional income [Bögenhold, Klinglmair, 2016c]. 
Our findings suggest that analyzing the categories of hybrid entrepreneurs shows strong differences according to their human capital. The higher the amount of human capital the higher is, on average, their income, especially income as employees. On the other hand, the lower the level of human capital, the more likely economic actors are just working part-time. Comparing the income of people with low and high human capital through self-employment shows first hand that there are no clear differences regarding education, but those with better education work shorter hours, thus they can realize a greater return on human capital. Neither segments differ regarding work satisfaction and intentions to grow.

We have to rethink the oft used dichotomous perspective when we look at self-employment. 'Black' and 'white' considerations are not sufficient to capture the richness of the actors under the self-employed banner and their specific forms of 'happiness' [Meager, 2015]. In a discussion full of synonyms, some of the affected persons do not even know to which category they belong [McKeown, 2015]. Probably one of the most promising tasks in research is the need to deliver generalizable theoretical contributions that differ from those established or are even in conflict with them [Di Gregorio, 2004]. The great heterogeneity and the very modest amount of 'classic' self-employed persons constitute a difficult challenge for research [Davidsson et al., 2010].

\section{References}

Acs Z., Audretsch D., Evans D. (1992) The Determinants of Variations in Self-Employment Rates Across Countries and Over Time (Discussion paper FS IV 92-3), Berlin: Wissenschaftszentrum Berlin für Sozialforschung.

Aloisi A. (2015) The Rising of On-Demand Work: A Case Study Research on a Set of Online Platforms and Apps. Paper presented at the IV Regulating for Decent Work Conference, ILO, Geneva, 8-10 July 2015.

Andersson D.E., Andersson Å.E. (2017) Time, Space, and Capital, Cheltenham: Edward Elgar.

Arum R., Müller W. (eds.) (2004) The Return of Self-Employment, Princeton: Princeton University Press.

Audretsch D. (2007) The entrepreneurial society, Oxford: Oxford University Press.

Baptista R., Karaöz M., Medoncs J. (2013) The impact of human capital on the early success of necessity versus opportunity-based entrepreneurs. Small Business Economics, vol. 42, no 4, pp. 831-847.

Baumol W.J. (1990) Entrepreneurship: Productive, Unproductive and Destructive. Journal of Political Economy, vol. 98, no 5, pp. 893-921.

Bell D. (1973) The Coming of Post-Industrial Society. A Venture in Social Forecasting, New York: Basic Books.

Bharat V. (2012) Strategic Outsourcing. The Alchemy to Business Transformation in a Globally Converged World, Heidelberg; New York; Dordrecht; London: Springer.

Blackburn R., Kovalainen A. (2008) Researching small firms and entrepreneurship: Past, present and future. International Journal of Management Review, vol. 11, no 2, pp. 127-148.

Bögenhold D., Fachinger U. (2013) Blurred Boundaries of Journalism: Multiple Employment in the Media Industry and the Hybridity of Occupational Work. International Journal of Arts and Commerce, vol. 2, no 10, pp. 171-183.

Bögenhold D., Fachinger U. (2016) Selbständige Erwerbsarbeit: Betrachtungen aus verschiedenen Perspektiven, Wiesbaden: VS Verlag.

Bögenhold D., Heinonen J., Akola E. (2014) Entrepreneurship and independent professionals: Social and economic logics. International Advances in Economic Research, vol. 20, no 3, pp. 295-310.

Bögenhold D., Klinglmair A. (2014) Motive für die Tätigkeit als Ein-Personen-Unternehmen in Kärnten - Ergebnisse einer empirischen Untersuchung. Wirtschaftspolitische Blätter - Sonderaus-gabe, S/14, pp. 137-158. Available at: http://bit.ly/2wtWMwG, accessed 15.06.2017.

Bögenhold D., Klinglmair A. (2015a) Micro-Entrepreneurship: Tendency towards Precarious Work? Empirical Findings for Austria. Athens Journal of Business and Economics, vol. 1, no 2, pp. 107-122.

Bögenhold D., Klinglmair A. (2015b) Female solo-self-employment. Features of gendered entrepreneurship. International Review of Entrepreneurship, vol. 13, no 1, pp. 47-58.

Bögenhold D., Klinglmair A. (2016a) Entrepreneurship and Hybrid Self-employment. Contemporary Entrepreneurship - Multidisciplinary Perspectives on Innovation and Growth (eds. D. Bögenhold, J. Bonnet, M. Dejardin, Pérez de Lema D.G.), Heidelberg; New York; Dordrecht; London: Springer, pp. 127-140.

Bögenhold D., Klinglmair A. (2016b) One-person enterprises and the phenomenon of hybrid self-employment: Evidence from an empirical study. Empirica, vol. 44, no 2, pp. 383-404.

Bögenhold D., Klinglmair A. (2016c) Independent work, modern organizations and entrepreneurial labor: Diversity and hybridity of freelancers and self-employment. Journal of Management \& Organization, vol. 22, no 6, pp. 843-858.

Bögenhold D., Staber U. (1991) The Decline and Rise of Self-Employment. Work, Employment and Society, vol. 5, no 2, pp. 223-239.

Burke A., Fitzroy F., Nolan M. (2008) What makes a Die-Hard Entrepreneur? Trying, or Persisting in Self-employment. Small Business Economics, vol. 31, pp. 93-115. DOI 10.1007/s11187-007-9086-6.

Burke A. (2011) The Role of Freelancers in the 21st century British Economy, London: PCG.

Burke A., Cowling M. (2015) The Use and Value of Freelancers: The Perspective of Managers. The Use and Value of Freelancers: The Perspective of Managers (ed. A. Burke), Dublin: Senate Hall Publishing, pp. 1-14.

Castells M. (2010) The Information Age. Economy, Society, and Culture, vol. I: The Rise of the Network Society, Oxford: Wiley-Blackwell.

Cieslik J. (2015) Capturing Statistically the "Intermediate Zone" Between the Employee and Employer Firm Owner. The Use and Value of Freelancers: The Perspective of Managers (ed. A. Burke), Dublin: Senate Hall Publishing, pp. 29-38.

Cieslik J. (2017) Entrepreneurship in Emerging Economies. Enhancing its Contribution to Socio-Economic Development, Heidelberg; New York; Dordrecht; London: Springer.

Davidsson P., Achtenhagen L., Naldi L. (2010) Small firm growth. Foundations and Trends in Entrepreneurship, vol. 6, no 2, pp. 69-166.

de Stefano V. (2015) The rise of the "just-in-time workforce": On-demand work, crowdwork and labour protection in the "gig-economy", Geneva: International Labour Office.

Deming D.J. (2015) The Growing Importance of Social Skills in the labour Market (NBER Working Paper 21473), Cambridge, MA: National Bureau of Economic Research. 
Di Gregorio D. (2004) Re-Thinking country risk: Insights from entrepreneurship theory. International Business Review, vol. 14, no 2, pp. 209-226.

Eurostat (2016a) Selbständigkeit nach Geschlecht, Alter und Beruf (lfsa_esgais). Available at: http://ec.europa.eu/ eurostat/data/database, accessed 21.12.2016.

Eurostat (2016b) Beschäftigung nach Geschlecht, Alter und Stellung im Beruf (lfsa_esgais). Available at: http:// ec.europa.eu/eurostat/data/database, accessed 21.12.2016.

Flew T. (2012) The Creative Industries. Culture and Policy, London: Routledge.

Florida R.L. (2002) The rise of the creative class. And how it's transforming work, leisure, community and everyday life, New York: Basic Books.

Folta T.B. (2007) Uncertainty rules the day. Strategic Entrepreneurship Journal, vol. 1, pp. 97-99.

Folta T.B., Delmar F., Wennberg K. (2010) Hybrid entrepreneurship. Management Science, vol. 56, pp. 253-269.

Friedman G. (2014) Workers without employers: Shadow corporations and the rise of the gig economy. Review of Keynesian Economics, vol. 2, no 2, pp. 171-188.

Hytti U. (2005) New meanings for entrepreneurs: From risk-taking heroes to safe-seeking professionals. Journal of Organizational Change Management, vol. 18, no 6, pp. 594-611.

Jin D. (2016) The Great Knowledge Transcendence. The Rise of Western Science and Technology Reframed, New York: Palgrave Macmillan.

Johal S., Anastasi G. (2015) From professional contractor to independent professional: The evolution of freelancing in the UK. Small Enterprise Research, vol. 22, no 2-3, pp. 159-172.

Kalleberg A.L. (2011) Good Jobs, Bad Jobs: The Rise of Polarized and Precarious Employment Systems in the United States, New York: Russell Sage Foundation.

Kautonen T., Down S., Welter F., Vainio P., Palmroos J. (2010) Involuntary self-employment as a public policy issue: A cross-country European view. International Journal of Entrepreneurial Behaviour and Research, vol. 16, no 1-2, pp. 112-129.

Kitching J., Smallbone D. (2012) Are freelancers a neglected form of small business? Journal of Small Business Enterprise Development, vol. 9, no 1, pp. 74-91.

Klinglmair A., Bögenhold D. (2014) Berufliche Zufriedenheit von Ein-Personen-Unternehmen in Kärnten Ergebnisse einer empirischen Untersuchung. Kärntner Jahrbuch für Politik 2014 (eds. K. Anderwald, P. Filzmaier, K. Hren), Klagenfurt: Hermagoras, pp. 197-218.

Kohli M. (2007) The institutionalization of the life course: Looking back to looking ahead. Resources of Human Development, vol. 4, pp. 253-571.

Mayer K.U. (2009) New directions in life course research. Annual Review of Sociology, vol. 35, pp. 413-433.

McCloskey D. (2010) The Bourgeois Dignity. Why Economics Can't Explain the Modern World, Chicago: Chicago University Press.

McKeown T. (2015) What's in a Name? The Value of "Entrepreneurs" Compared to "Self-Employed" ... But What about "Freelancing" or "IPro". The Handbook of Research on Freelancing and Self-Employment (ed. A. Burke), Dublin: Senate Hall Publishing, pp. 121-135.

McKeown T. (2016) A consilience framework: Revealing hidden features of the independent contractor. Journal of Management and Organization, vol. 22, no 6, pp. 779-796.

McKinsey Global Institute (2016) Independent Work: Choice, Necessity, and the Gig Economy, San Francisco: McKinsey Global Institute.

Meager N. (2015) Job quality and self-employment: Is it (still) better to work for yourself? The Handbook of Research on Freelancing and Self-Employment (ed. A. Burke), Dublin: Senate Hall Publishing, pp. 35-46.

Mokyr J. (2002) The Gifts of Athena. Historical Origins of the Knowledge Economy, Princeton: Princeton University Press.

OECD (2015) OECD Labour Force Statistics 2014, Paris: OECD.

OECD (2017) Self-employment rate. Available at: https://data.oecd.org/emp/self-employmentrate.htm, accessed 21.01.2016.

Oshri I., Kotlarsky J., Willcocks L. (2008) Outsourcing global services: Knowledge, innovation and social capital, Basingstoke: Palgrave Macmillan.

Raffiee J., Feng J. (2014) Should I quit my Job? A hybrid path to entrepreneurship. Academy of Management Journal, vol. 57 , no 4 , pp. $936-963$

Ritzer G. (1993) The McDonaldization of society: An investigation into the changing character of contemporary social life, Thousand Oaks: Pine Forge Press.

Schulz M., Urbig D., Procher V. (2016) Hybrid entrepreneurship and public policy: The case of firm entry deregulation. Journal of Business Venturing, vol. 31, no 3, pp. 272-286.

Schumpeter A. (1942) Capitalism, Socialism and Democracy, New York: Harper \& Row.

Shane S., Venkataraman S. (2000) The Promise of Entrepreneurship as a Field of Research. Academy of Management Review, vol. 25, pp. 217-226.

Shevchuk A., Strebkov D. (2015) The rise of freelance contracting on the Russian-language internet. Small Enterprise Research, vol. 22, no 2-3, pp. 146-158.

Staber U., Bögenhold D. (1993) Self-Employment: A Study of Seventeen OECD Countries. Industrial Relations Journal, vol. 25, no 2, pp. 128-139.

Statistik Austria (2015) Arbeitsmarktstatistiken - Ergebnisse der Mikrozensus Arbeitskräfteerhebung und der OffenenStellen-Erhebung, Vienna: Verlag Österreich.

van Stel A., de Vries N. (2015) The Economic Value of Different Types of Solo Self-Employment: A Review. The Use and Value of Freelancers: The Perspective of Managers (ed. A. Burke), Dublin: Senate Hall Publishing, pp. 77-84.

Weber M. (2003) The Protestant Ethic and the Spirit of Capitalism, New York: Dover Publications.

Weber M. (1978) Economy and Society: An Outline of Interpretive Sociology, Berkeley: University of California Press.

Welter F. (2011) Contextualizing entrepreneurship - conceptual challenges and ways forward. Entrepreneurship Theory and Practice, vol. 35, no 1, pp. 164-184.

Wirtschaftskammer Österreich (2015) Ein-Personen-Unternehmen (EPU) 2015. EPU-Anteil nach Sparten (Mehrfachmitgliedschaften) (EinzelunternehmerInnen, $G m b H$ ), Vienna: Wirtschaftskammer Österreich.

Wynn M. (2016) Chameleons at large: Entrepreneurs, employees and firms - the changing context of employment relationships. Journal of Management and Organization, vol. 22, no 6, pp. 826-842. 


\title{
Recruiting and Job Search Technologies in the Age of Internet
}

\author{
Sergey Roshchin \\ Vice-rector, Laboratory Head, Laboratory for Labour Market Studies, sroshchin@hse.ru \\ Sergey Solntsev \\ Deputy Laboratory Head, Laboratory for Labour Market Studies, ssolntsev@hse.ru \\ Dmitry Vasilyev \\ Student, International College of Economics and Finance, dmvas2007@gmail.com
}

National Research University Higher School of Economics, 20, Myasnitskaya str., Moscow 101000, Russian Federation

\begin{abstract}
$\mathrm{T}$ This article considers recruiting via the internet as an organizational innovation at Russian companies. Using data from a survey of employers and the Russian Longitudinal Monitor Survey (RLMS)-HSE, we measured the scale of internet-use by employers for recruiting and by employees for job searches, and the factors influencing them. In general, the characteristics of employees and workplaces

match. Amid companies, internet use was more common in the retail sector among privately owned and financially successful firms. The internet was more actively used by workers with higher or specialized education from big cities. Internet searches complement other channels and has become the second most popular channel after searching through relatives and friends.
\end{abstract}

\section{Keywords:}

organizational innovation; Internet; human resource management; job search; recruiting.
Citation: Roshchin S., Solntsev S., Vasilyev D. (2017) Recruiting and Job Search Technologies in the Age of Internet. Foresight and STI Governance, vol. 11, no 4, pp. 33-43. DOI: 10.17323/2500-2597.2017.4.33.43 
$\mathrm{O}$ ver the first few years following the emergence of the internet the range of its users remained rather limited, and its proliferation was quite modest. The internet became generally accessible only in the early 2000s. The explosive development of, and reduced prices for, smartphones and other mobile devices at the end of this decade allowed for the extension of the coverage to users who do not own a computer or a subscription to a wired connection. In 2014, $67 \%$ of the Russian population aged between 15-72 had internet access [Rosstat, 2015a]. Against the background of a growing audience, businesses began to be interested in the internet as well; companies specializing in internet-based activities began to appear. Today practically all medium and large firms use the internet in their daily operations, along with a significant share of small enterprises [HSE, 2016].

One area affected by the development of the internet was the recruitment and job search processes, which are analyzed in this paper. Recruitment and job searches, such as the hiring and job placement stages, includes selecting the best candidates and vacancies, interviewing and other techniques used to assess candidates' abilities, leading to the signing of an employment contract. According to a survey conducted by Boston Consulting Group (BCG) in 2014, about 55\% of people who have changed jobs used the internet to find a new one [Sakurai, Okudo, 2015]. Globally, 33\% of the respondents said they believed this approach was the most efficient and $48 \%$ in Russia share this belief. The authors of the survey note that this attitude prompted companies to make better use of the internet for recruitment purposes.

Recruitment is a key element of companies' HR policies. Their success in finding employees that meet the relevant requirements regarding qualifications, experience, skills, etc. largely determines the results of their overall activities [Jovanovic, 1979]. According to an employers' survey conducted by the Ancor recruiting agency, recruitment, hiring and training remain among the top priorities of Russian companies' HR policies [Ancor, 2014]. The internet allows firms to fill job openings with the best candidates, thus contributing to overall productivity and the achievement of the optimal balance between the employees' qualifications and job requirements [Autor, 2001; Kuhn, 2014]. It provides an example of both the companies' organizational innovations and the innovative behavior of the population alike.

Relatively few studies of recruitment- and job seeking-related issues have been conducted in Russia so far. Studies of approaches to choosing job search techniques could be noted in this context [Roshchin Markova, 2004], along with research on graduates' behavior on the labour market [Naryshkina, 2007] and the role of job seekers' social circles [Yakubovich, 2002; Stuken, 2008]. The subject of recruitment is even more poorly studied. A monograph [Avraamova et al., 2006] based on a survey of 1,500 companies concludes that personal relations remain the main recruitment channel, followed by cooperation with universities and professional communities, while the least popular hiring technique is advertising in the media. Certain related issues such as choosing between outsourcing and retraining one's own staff are analyzed in [Denisova, Lazareva, 2006; Roshchin, Travkin, 2015]; these publications focus on staff training mechanisms.

The authors do not know of any studies on the role the internet plays in job search or recruiting activities in Russia. This paper is the first attempt to measure the extent of internet usage on the Russian labour market, to assess the factors affecting it, and its popularity among employers and job seekers.

\section{The Role of the Internet in the Search for Jobs and Recruitment by Companies}

One consequence of the wide proliferation of the internet was the use of organizational innovations ${ }^{2}$ in companies' recruitment policies, which allowed them to significantly increase the productivity of $\mathrm{HR}$ departments and cut the costs associated with advertising vacancies, the use of specialized software, the collection and processing of job seekers' resumes, and interviewing. This resulted in an extended range of applicants, more efficient screening, and reduced administrative and operational recruiting and hiring costs, which according to the OECD Oslo Manual's terms [OECD, Eurostat, 2005] means organizational innovation. Employers and job seekers use the internet for (1) the publishing of and search for information about job vacancies and job seekers, and (2) communication.

Numerous online services and platforms allow one to advertise job openings and publish job seekers' resumes3:

- specialized websites; the most prominent ones in Russia are HeadHunter.ru (21 million resumes as of June 2016) and SuperJob.ru (17 million resumes) ${ }^{4}$;

- corporate websites advertising job vacancies;

- the public employment service's website (the job database at TrudVsem.ru);

- private recruiting agencies' websites;

\footnotetext{
${ }^{1}$ The survey covered 13,000 people in Australia, Brazil, the UK, Germany, India, Italy, Canada, China, Russia, the US, France, South Africa, and Japan.

${ }^{2}$ For more on the typology of innovations see the Oslo Manual: Guidelines for Collecting and Interpreting Innovation Data [OECD, Eurostat, 2005], which is used in Russia to collect relevant corporate statistics.

${ }^{3}$ A review of the use of various internet-based recruiting tools is presented in [Nakamura et al., 2009]. Changes in the US job seekers' strategies caused by development of the internet are analyzed in [Jansen et al., 2005]
} 
- mass media websites publishing job vacancies;

- internet advertising;

- social networks, specialized (such as LinkedIn) ${ }^{5}$ and general ones such as VK.com, OK.ru, and Facebook.

The internet allows one to significantly simplify and speed up the process of finding jobs/workers, achieve the best match between candidates and vacancies, and extend the range of both the former and latter alike as far as possible. Studies of the US, German, and South Korean labour markets reveal that the use of the internet allowed the unemployed to make their job search more efficient [Stevenson, 2008], cutting its duration by 7-25\% [Kuhn, Mansour, 2014; Suvankulov et al., 2012]. ${ }^{6}$ Recruiting websites permit employers and job seekers to automatically filter resumes/vacancies, i.e., to conduct the initial screening of applicants/openings, which considerably cuts relevant costs for both sides [Kuhn, 2014].

The internet's communication function amounts to making communication between employers, job seekers, and employment agencies much simpler and less expensive. Present-day recruitment-relevant communication channels include the following:

- email;

- audio and video conference calls (such as via Skype, etc.) for interview purposes;

- instant messengers for quick communication between job seekers and employers/recruiters;

- websites offering a specialized resume-drafting functionality;

- e-portfolios.

Reduced time and financial costs (which are particularly evident in the case of younger, better educated job seekers [Sakurai, Okudo, 2015]) allow them to apply for a larger number of vacancies, while employers have a larger selection of job candidates. Ultimately, this can lead to reduced information asymmetry and reduced transaction costs for both sides during the recruitment process [Autor, 2001]. Empirical evidence of the higher efficiency of an internet-based job search is provided by the reduced labour attrition rate [Beard et al., 2012], the increased probability of signing employment contracts [Kuhn, Skuterud, 2004], the reduced period of unemployment [Suvankulov et al., 2012], and a smaller share of irrelevant offers [Jansen et al., 2005]. The advantages of using the internet as a communication channel are discussed in [Stevenson, 2003], where the authors analyze data flows emerging over the course of one's job search.

However, the internet's obvious strengths do not completely offset certain liabilities its use involves.

1. Unreliable information. Data about job vacancies or job seekers published on the internet may be incomplete or even incorrect, with only limited opportunities to verify the facts. Accordingly, hiring almost never takes place without personal contact between the job seeker and the employer. As is shown in [Marchal et al., 2005], quantifiable data has the highest demand on recruiting websites and companies do their own screening, which increases information asymmetry between employers and employees along with the companies' recruitment costs.

2. Increased time for job search and candidate selection. The extended range of potential job candidates may slow down their screening. At the same time, the increased number of available job openings can slow down the process of finding the right person or job [Fountain, 2005].

3. Technological development rate. Some job seekers' internet experience may be insufficient to participate in a video conference interview. Thus, the internet ceases to be a potential advantage and turns into a barrier that hinders successful employment. Employers are less likely to encounter such problems, but even in their case the lack of technological competences may become a negative factor.

Quantitative data allows one to measure the internet's popularity as a medium and a tool for recruitment and finding jobs.

\section{Data}

Empirical data for our study consists of the results of enterprise and individual surveys. In the first case, we used the "Interaction between External and Internal Labour Markets" (IEILM) 7 survey conducted in 2010-2014 for the HSE Laboratory for Labour Market Studies. The participants of the annual survey comprised enterprises operating in various sectors of the economy (mining, manufacturing, construction, transport and communications, trade, financial, and other services) with more than 30 employees, which were located in various Russian regions. Educational and medical institutions were excluded from the sample as they are financed predominantly through the public budget. ${ }^{8}$ The final sample comprised

\footnotetext{
${ }^{4}$ The use of the US job vacancies site Monster.com was analyzed in [Brenčič, Norris, 2012].

5 The social network for professionals, LinkedIn, is analyzed in [Garg, Telang, 2011]; a similar research study based on data about retired US military personnel is presented in [Weinburger et al., 2015]; a review of Russian recruiting social media and their usage can be found in [Tikhonova, 2015].

${ }^{6}$ In earlier research [Fountain, 2005; Kuhn, Skuterud, 2000] based on data for the late 1990s - early 2000s, the authors noted that using the internet had no effect on the duration of the job search; a discussion of this fact is presented in [Kuhn, 2014].

For more about the project see: https://www.hse.ru/org/projects/13315049, last accessed on 15.06.2016.

${ }^{8}$ Public sector organizations were excluded due to their lack of freedom to shape their HR policies (including hiring), less appealing work conditions, and lower pay [Gimpelson, Lukyanova, 2006; Sharunina, 2016]
} 
Figure 1. Dynamics of the Use of the Internet and Other Recruitment Channels by Russian Companies in 2010-2014 (\% of all companies)
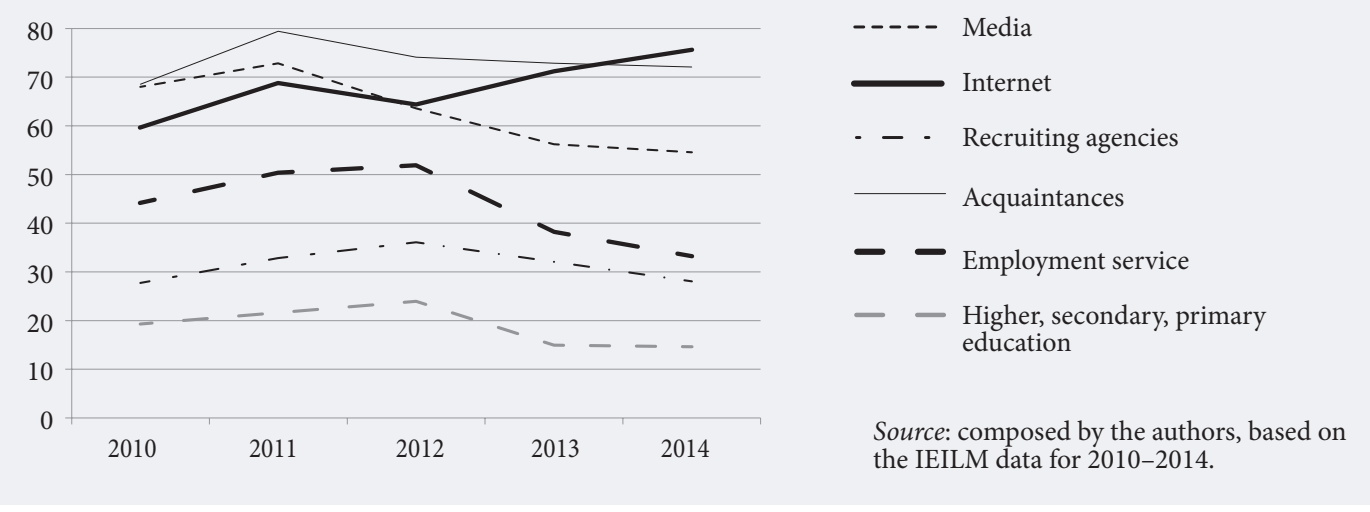

7,847 observations: 1,008 in $2010,1,329$ in $2011,1,505$ in 2012, 2,002 in 2013, and 2,003 in 2014. The weighted averages were calculated on the basis of the total number of enterprises in the relevant sectors of the Russian economy, according to Rosstat data.

To assess companies' use of the internet for recruitment purposes, they were asked "Which recruitment channel does your company use most often to fill managerial/professional vacancies?" One of the answer options was "We try to find candidates ourselves using various internet-based sources". ${ }^{9}$ We assume that by the latter, most of the respondents mean specialized online recruitment services.

Internet usage by job seekers was measured on the basis of Russian Longitudinal Monitoring Survey (RLMS-HSE) ${ }^{10}$ data for 2006-2014. Over the course of the survey, respondents in various Russian regions were asked questions about their employment, income, socio-demographic characteristics, etc. In 2006, "Internet advertising (recruitment websites)" was added to the list of job search channels, and the answer options for the question "How did you find your current job?" were supplemented with "Placed an ad on the internet" and "Saw an ad on the internet". These provided the empirical basis for our study. Data on regional unemployment was taken from Rosstat's "Population Employment Survey". ${ }^{11}$

An analysis of the data about employers and job seekers allowed us to study the use of the internet by both sides of the labour market, and assess the symmetry of their respective perspectives. Below we describe the level of internet use for recruitment and the selection of employees, and then, through the application of descriptive statistics and regression analysis, we identify the factors that increase the probability of corporate and individual use of the internet for these purposes.

\section{The Internet as a Recruitment and Job Search Tool: The Scale and the Dynamics}

The IEILM data allows one to measure the scale and the trends of companies' usage of the internet and other recruitment channels during 2010-2014. If at the beginning of the decade the internet was less popular than conventional media and personal connections, five years later it has achieved full domination (Figure 1). ${ }^{12}$ Note that use of other channels either remained unchanged (acquaintances and private recruiting agencies), or dropped in use (media, public employment services, universities), which gives one ground to speak about their gradual demise.

We look at the groups of employees for which companies use the internet during the hiring process, and what the trends were observed over the five-year period (Figure 2). Most often the internet was used to find professionals, less commonly - managers, manual workers, and junior office workers. During the five years in question the share of companies using the internet to recruit personnel grew in all three of the aforementioned segments; the gap between professionals on the one hand, and managers and lowerskilled workers, on the other, has narrowed from $12-13 \%$ in 2010 to $8 \%$ in 2014.

An analysis of corporate recruitment strategies reveals that the most popular way of recruiting involves using the internet in combination with other channels, first of all, acquaintances. In 2010-2014, the share of companies who used this approach grew from 55\% to $67 \%$, while the share of those making do without

\footnotetext{
9 Other answer options (recruitment channels) included: "We try to find candidates ourselves using publications in printed media"; "We try to find candidates ourselves using recommendations by acquaintances, colleagues, other employees, etc."; "We hire recruitment (HR) agencies"; "We go to the public employment service"; "We go to universities".

${ }^{10}$ For more about the project see: https://www.hse.ru/en/rlms/, last accessed on 15.06.2016.

${ }^{11}$ For more about the project see: http://www.gks.ru/wps/wcm/connect/rosstat_main/rosstat/ru/statistics/publications/catalog/ doc_1140097038766, last accessed on 15.06.2016.

${ }^{12}$ According to the Ancor agency, 93\% of Russian companies used internet-based resources in 2014 [Ancor, 2014]. An earlier study showed that in 2006, only about one third of companies used the internet to fill their vacancies, while personal contacts were the most popular channel [Avraamova et al., 2006].
} 
Figure 2. Use of the Internet as the Primary

Recruitment Channel to Hire Various Personnel Groups (\% of the respondents' answers)

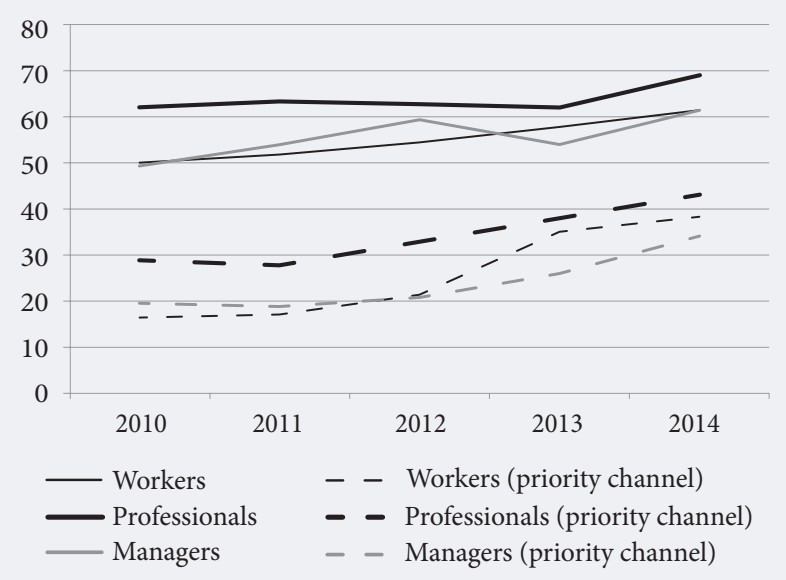

Note: dotted lines indicate that the internet was used as priority recruitment channel to hire certain personnel groups).

Source: composed by the authors, based on IEILM data for 2010-2014.
Figure 3. Application of Different

Recruitment Strategies by Companies

(\% of the respondents' answers)

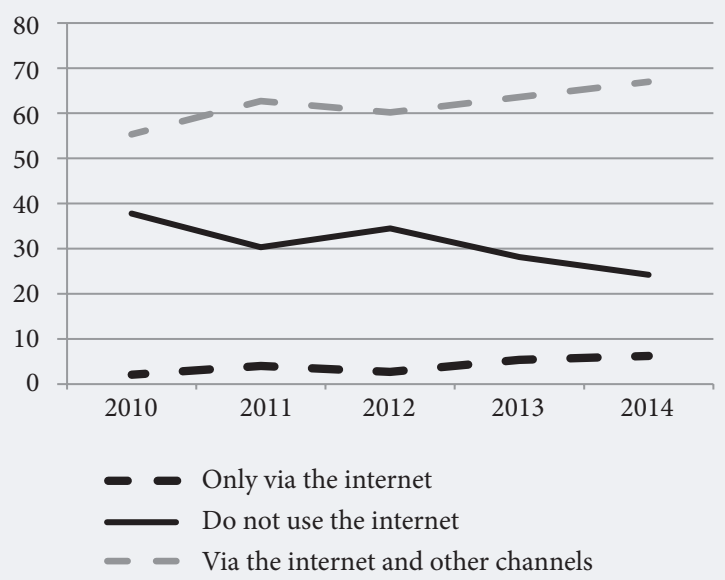

Source: composed by the authors, based on IEILM data for 2010-2014.

the internet dropped from $38 \%$ to $24 \%$ (Figure 3). Exclusively offline strategies were less popular than online ones: a 35\% drop against 29\% growth, respectively. Despite the four-fold growth in the share of companies that recruit their staff via the internet alone, in absolute terms this approach to hiring remains rather unpopular: $1.7 \%$ in 2010 and $6.7 \%$ in 2014.

The extent of using the internet to find jobs was measured on the basis of the RLMS-HSE data for 20062014 (Figure 4). The use of online resources demonstrated high growth, from 13\% to $49 \%$ in eight years, making the internet the third most popular job search channel, with other sources of vacancies either retaining or slightly losing their positions. However, friends' and relatives' help still remains at the top of the list.

The changes in various job search strategies' popularity in some ways reflect the trends in recruitment for employers (Figure 5). A complete refusal to use the internet was less common (a 35\% reduction) than strategies which did imply its use (29\% growth). However, only a small share of job seekers ( $8 \%$ in 2014) relied exclusively on the internet.

About $7.5 \%$ of the respondents said they found their current job via the internet (Table 1). This approach is more common for medium-skilled professionals (10\%), tradesmen (11\%), and unskilled workers (12\%). Sector-wise, light industry (14\%), health and welfare (10\%), and trade (10\%) stand out. Highly skilled professionals, agricultural, and skilled industrial workers find jobs via the internet much less often, along with those employed in mining, heavy industry, agriculture, and public service.

\section{Figure 4. Use of Job Search Channels (\% of all job seekers)}

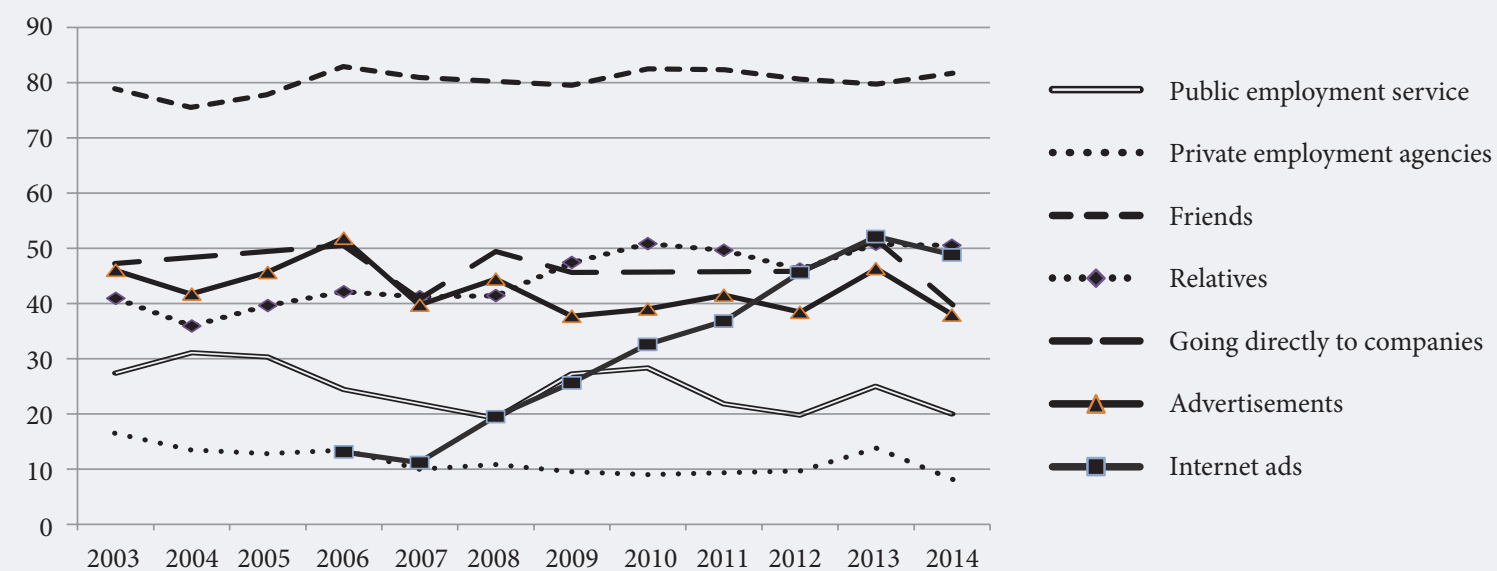

Source: composed by the authors, based on IEILM data for 2003-2014. 


\section{Figure 5. Dynamics of the Popularity of Job Search Strategies (\% of all job seekers)}

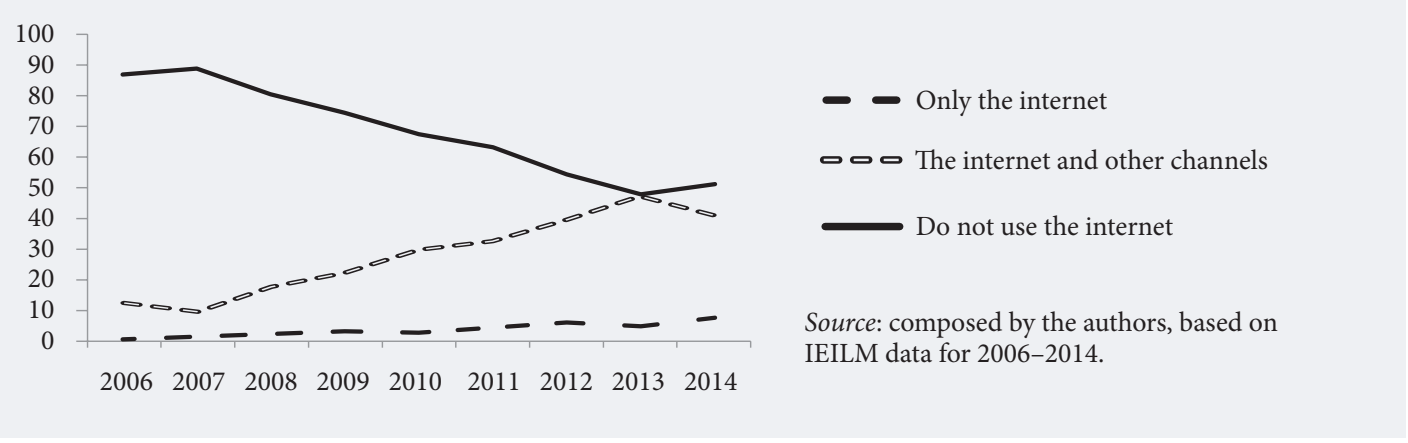

\section{The Use of the Internet for Recruitment Purposes}

Descriptive statistics on companies' use of the internet for recruitment purposes reveal significant discrepancies between various industries (Table 2). The highest interest in the internet as a recruitment channel is demonstrated by financial (skilled and administrative personnel) and trading (all personnel groups) companies; much less interested are construction firms (all personnel groups), together with mining (manual workers), manufacturing (administrative), and transport and communications (administrative) companies, i.e., the more conventional industries. ${ }^{13}$ Differences in internet usage between small, medium, and large companies are negligible.

Companies paying low wages are less likely to use the internet to recruit staff; as for the recruitment of managers, no linear correlation was discovered. Contrary to expectations, the probability of using the internet for recruiting purposes increases along with companies' financial health. Despite the low costs associated with this approach, companies do not see it as a way to cut their recruitment expenditures. Firms headed by young CEOs more often make use of the opportunities offered by the internet, while the level of companies' innovation activity has no appreciable impact upon this indicator. Companies in Moscow and St. Petersburg are the leaders in online recruitment, while small Russian towns lag far behind them.

An econometric analysis of the factors affecting companies' use of the internet for recruitment purposes (Table 3) on the whole confirms the descriptive statistics.

The lack of a correlation between companies' innovation activity and the use of the internet for recruitment purposes suggests such that such practices are quite common in companies' HR policies. Trading and financial firms tend to be more active in this regard, followed by mining and construction enterprises. A possible explanation is that the candidates' specific skills are less important in trade, while automatic screening allows a firm to efficiently select suitable people for subsequent interviews. Also, the internet allows one to cut recruitment costs, which is important in a high-turnover industry. ${ }^{14}$

Practically no differences were discovered between the level of internet usage by small, medium, and large companies, which was not the case regarding the average wages they paid. Firms paying up to

\section{Table 1. Shares of Respondents Who Found Their Current Job on the Internet (\%)}

\begin{tabular}{|l|c|l|c|}
\hline Total & $\mathbf{7 . 5}$ & By sector of economy & \\
\hline By occupation & & Light industry & 14.0 \\
\hline Managers, executives & 6.7 & Mining and heavy industry & 1.6 \\
\hline Highly skilled professionals & 0 & Construction, transport, communications & 6.0 \\
\hline Medium-skilled professionals & 10.1 & Agriculture, fisheries, forest industry & 0 \\
\hline Office workers & 5.4 & Public administration & 1.4 \\
\hline People employed in trade and services & 11.2 & Education, science, culture & 6.1 \\
\hline Skilled agricultural workers & 0 & Health, welfare & 10.2 \\
\hline Skilled manual workers & 3.2 & Trade, household and communal services & 10.3 \\
\hline Skilled machine operators & 4.3 & Finance, insurance & 4.0 \\
\hline Unskilled workers & 12.3 & Other & 5.3 \\
\hline Source: composed by the authors, based on IEILM data for 2014. \\
\hline
\end{tabular}

${ }^{13}$ In 2006, trading and ICT companies used the internet for recruitment purposes most actively, while mining firms were the least active.

${ }^{14}$ According to Rosstat data, in 2014 labour turnover in trade was $90 \%$ higher than the average for the whole economy [Rosstat, 2015b]. 


\section{Table 2. Shares of Companies Who Use the Internet to Recruit Various Personnel Groups (\%)}

\begin{tabular}{|c|c|c|c|c|}
\hline Indicators & Workers & Professionals & Management & Total \\
\hline Average & 62 & 70 & 62 & 76 \\
\hline \multicolumn{5}{|l|}{ Sector of economy } \\
\hline Mining & 42 & 67 & 58 & 76 \\
\hline Manufacturing & 63 & 68 & 55 & 75 \\
\hline Construction & 50 & 58 & 53 & 64 \\
\hline Trade & 72 & 76 & 69 & 80 \\
\hline Transport and communications & 59 & 65 & 52 & 70 \\
\hline Finance & 59 & 78 & 78 & 84 \\
\hline Services & 56 & 69 & 64 & 76 \\
\hline \multicolumn{5}{|l|}{ Number of employees } \\
\hline $30-50$ & 60 & 73 & 63 & 76 \\
\hline $51-100$ & 63 & 67 & 59 & 75 \\
\hline $101-250$ & 61 & 73 & 66 & 72 \\
\hline $251-1000$ & 63 & 70 & 64 & 78 \\
\hline $1000+$ & 59 & 73 & 70 & 77 \\
\hline \multicolumn{5}{|l|}{ Average monthly wage (thousand rubles) } \\
\hline Under 19.9 & 46 & 57 & 50 & 64 \\
\hline $20.0-24.9$ & 59 & 73 & 71 & 81 \\
\hline $25.0-34.9$ & 66 & 73 & 62 & 78 \\
\hline $35.0+$ & 69 & 81 & 68 & 86 \\
\hline \multicolumn{5}{|l|}{ Financial situation } \\
\hline Poor or average & 58 & 66 & 60 & 74 \\
\hline Good & 70 & 77 & 67 & 80 \\
\hline \multicolumn{5}{|l|}{ Innovative $^{\mathrm{I}}$} \\
\hline Yes & 64 & 70 & 63 & 78 \\
\hline No & 61 & 69 & 61 & 77 \\
\hline \multicolumn{5}{|l|}{ Making large investments } \\
\hline Yes & 61 & 69 & 69 & 77 \\
\hline No & 62 & 70 & 61 & 76 \\
\hline \multicolumn{5}{|l|}{ Ownership } \\
\hline Public $^{\mathrm{II}}$ & 33 & 43 & 43 & 55 \\
\hline Private, fully Russian-owned & 63 & 71 & 63 & 77 \\
\hline Private, with international participation & 65 & 75 & 62 & 83 \\
\hline \multicolumn{5}{|l|}{ CEO's age } \\
\hline Under 39 & 65 & 76 & 68 & 82 \\
\hline $40-49$ & 63 & 71 & 64 & 78 \\
\hline $50-59$ & 56 & 62 & 56 & 70 \\
\hline $60+$ & 67 & 74 & 60 & 81 \\
\hline \multicolumn{5}{|l|}{ Location (city) } \\
\hline Moscow or St. Petersburg & 61 & 77 & 71 & 81 \\
\hline 1 million + & 61 & 68 & 60 & 74 \\
\hline $500,000-1$ million & 68 & 75 & 58 & 79 \\
\hline $100,000-500,000$ & 60 & 66 & 60 & 72 \\
\hline 100,000 or fewer & 55 & 54 & 60 & 65 \\
\hline \multicolumn{5}{|c|}{ 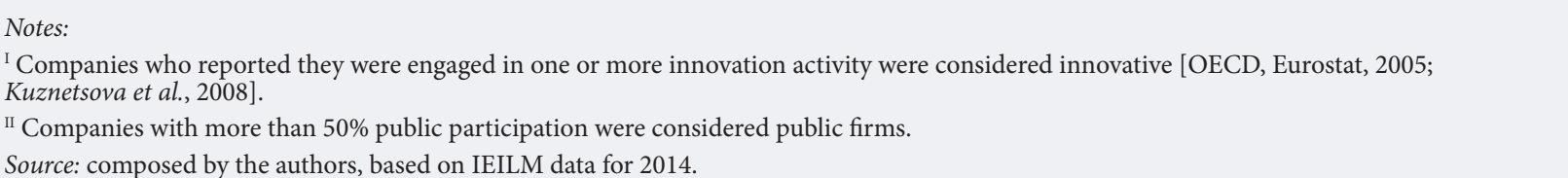 } \\
\hline
\end{tabular}

20,000 rubles a month tend to use online resources much more actively, unlike those paying a higher wage. Public companies use the internet much less often with no appreciable changes in this regard since 2006 [Avraamova et al., 2006]. Another less important factor is the CEO's age. The use of online resources is lower in smaller cities (with populations below 100,000), and higher in medium ones (500,000 - 1 million).

Companies' use of recruitment opportunities offered by the internet is directly connected with their financial situation (indicators such as their balance sheet, the average wages they pay, whether they operate in highly competitive industries) and their interest in hiring highly skilled personnel, but not with their need to cut recruitment costs. Low internet usage by public companies is evidence of their technological inertia and low competitiveness. Ultimately, the less advanced companies tend to hire less advanced and less productive workers. 
Table 3. Factors affecting companies' internet usage, probit model, and dependent variable: using the internet to recruit various personnel groups (\%)

\begin{tabular}{|c|c|c|c|c|}
\hline Indicators & Workers & Professionals & Management & Total \\
\hline \multicolumn{5}{|l|}{ Sector (Manufacturing) } \\
\hline Mining & $-0.245^{\star \star}$ & -0.110 & 0.048 & 0.052 \\
\hline Construction & $-0.100^{*}$ & -0.072 & -0.033 & $-0.108^{\star *}$ \\
\hline Trade & $0.085^{\star \star}$ & $0.067^{*}$ & $0.086^{\star *}$ & 0.042 \\
\hline Transport and communications & -0.005 & 0.044 & -0.063 & -0.009 \\
\hline Finance & -0.043 & $0.115^{\star *}$ & $0.174^{\star * *}$ & 0.069 \\
\hline Services & -0.011 & 0.048 & $0.096^{* *}$ & 0.047 \\
\hline \multicolumn{5}{|l|}{ Number of employees $(30-50)$} \\
\hline $51-100$ & 0.049 & -0.042 & -0.040 & -0.019 \\
\hline $101-250$ & 0.067 & 0.011 & 0.079 & 0.031 \\
\hline $251-1000$ & $0.085^{\star *}$ & 0.000 & 0.014 & 0.027 \\
\hline $1000+$ & 0.114 & 0.070 & 0.083 & 0.063 \\
\hline \multicolumn{5}{|c|}{ Average monthly wage (thousand rubles) (20.0-24.9) } \\
\hline Under 19.9 & $-0.191^{* * *}$ & $-0.142^{* * *}$ & $-0.130^{* * *}$ & $-0.141^{* * *}$ \\
\hline $25.0-34.9$ & $-0.097^{\star *}$ & -0.050 & $0.102^{\star *}$ & -0.012 \\
\hline $35.0+$ & -0.000 & 0.045 & $0.078^{*}$ & 0.045 \\
\hline \multicolumn{5}{|l|}{ Company situation } \\
\hline Good financial situation & $0.102^{\star * *}$ & $0.100^{* * *}$ & $0.067^{\star *}$ & $0.079^{* * *}$ \\
\hline Innovative & -0.012 & -0.018 & -0.019 & -0.037 \\
\hline Making large investments & -0.013 & 0.047 & $0.113^{\star * *}$ & $0.061^{\star}$ \\
\hline \multicolumn{5}{|l|}{ Ownership (Private, fully Russian-owned) } \\
\hline Public & $-0.226^{\star * *}$ & $-0.294^{* * *}$ & $-0.313^{* * *}$ & $-0.335^{\star * *}$ \\
\hline Private, with international participation & -0.014 & -0.018 & $-0.267^{\star * *}$ & -0.052 \\
\hline \multicolumn{5}{|l|}{ CEO's age $(40-49)$} \\
\hline Under 39 & 0.045 & $0.080^{* *}$ & 0.052 & 0.052 \\
\hline $50-59$ & -0.037 & -0.054 & -0.064 & $-0.058^{*}$ \\
\hline $60+$ & 0.020 & 0.012 & 0.027 & -0.007 \\
\hline \multicolumn{5}{|l|}{ Location (1 million + ) } \\
\hline Moscow or St. Petersburg & 0.014 & 0.006 & -0.035 & 0.010 \\
\hline $500,000-1$ million & -0.002 & $0.070^{*}$ & $0.135^{\star * *}$ & $0.097^{* * *}$ \\
\hline $100,000-500,000$ & 0.044 & 0.047 & 0.006 & 0.053 \\
\hline 100,000 or fewer & -0.034 & $-0.154^{\star *}$ & -0.118 & $-0.105^{\star}$ \\
\hline Observations & 1111 & 1137 & 996 & 1164 \\
\hline Pseudo $\mathrm{R}^{2}$ & 0,055 & 0,076 & 0,083 & 0,086 \\
\hline
\end{tabular}

\section{The Use of the Internet to Find Jobs}

The use of the internet to find a job has certain specific features depending on the job seekers' sociodemographic characteristics (Table 4). Young and middle-age cohorts (16-45) tend to more actively use the internet for these purposes, along with people whose education level is above average, and residents of large cities (Moscow, St. Petersburg, regional capitals, and other cities). Studies of the US labour market cite similar data regarding job seekers' education level [Kuhn, Mansour, 2014] and age [Kuhn, Skuterud, 2004].

Over the course of the econometric analysis, we assessed factors affecting internet usage by job seekers (Model 1) and companies (Model 2). In the first case (Table 5), a binary choice probit model was used: the use of the internet to find a job served as dependent variable and the respondents' personal characteristics (age, gender, family status, education, etc.), place of residence, and the year of the survey were used as explanatory variables.

The analysis allowed us to arrive at several major conclusions. Firstly, a higher level of education increases the probability of using the internet to find a job; a possible explanation is the correlation between both these characteristics and computer literacy. On the other hand, age does not affect the likelihood of using the internet: job seekers in various age cohorts are equally likely to make use of online resources. Secondly, the larger the city, the more often its residents try to find jobs online. Thirdly, between 20102014 , the probability of using the internet to find a job grew by $22 \%$. 
Table 4. Shares of People Who Use the Internet to Find Jobs in Various Job Seeker Groups (\%)

\begin{tabular}{|c|c|c|c|}
\hline Total & 48.8 & & \\
\hline Gender & & Education & \\
\hline Male & 44.2 & Below secondary & 37.9 \\
\hline Female & 54.4 & Secondary & 37.5 \\
\hline \multicolumn{2}{|l|}{ Age } & \multirow[t]{2}{*}{ Vocational, below secondary } & \multirow[t]{2}{*}{21,4} \\
\hline $16-19$ & 68.8 & & \\
\hline $20-24$ & 63.0 & \multirow[t]{2}{*}{ Vocational secondary } & \multirow[t]{2}{*}{38.6} \\
\hline $25-29$ & 51.6 & & \\
\hline $30-34$ & 53.2 & Secondary professional & 55.1 \\
\hline $35-39$ & 55.6 & Tertiary & 73.6 \\
\hline $40-44$ & 50.9 & Place of residence & \\
\hline $45-49$ & 29.8 & Moscow, St. Petersburg & 76.7 \\
\hline $50-54$ & 28.8 & Regional capital & 64.3 \\
\hline $55-59$ & 40.6 & City & 52.3 \\
\hline $60-64$ & 25.0 & Town & 14.3 \\
\hline $65+$ & 11.1 & Village & 25.5 \\
\hline
\end{tabular}

In the scope of the second model, we measured how using the internet affected job search success in 2010-2013 (data for 2014 was only used to estimate the probability of finding a job) (Table 5). Actually getting employed served as a binary choice dependent variable (did the respondents who were seeking jobs during the period in question find one during the next period?). The same explanatory variables as those in the first model were used in the second plus the use of the internet to find a job. The calculations confirmed the importance of the latter factor for the model: it increased the probability of finding a job by $4.5 \%$. Studies of other countries' labour markets present similar results: using the internet increased the chances of finding a job by $7.1 \%$ and $12.7 \%$ in Germany and South Korea, respectively [Suvankulov et al., 2012]. The internet allows one to find jobs quicker, and does not rule out using other channels such as asking friends, relatives, acquaintances, etc., for help.

Factors affecting the use of the internet by job seekers and employers show a good match between one another (as far as it is possible to compare them). Both sides of the hiring process prefer to combine various search channels. Companies more often use the internet to recruit professionals, and less often do so when hiring managers and manual workers; similarly, professionals more frequently find jobs via the internet than managers and workers do. Industry-wise, trade uses the internet for recruitment purposes more actively than other sectors of the economy. Job seekers and companies in small towns significantly lag behind large cities in this respect.

\section{Conclusion}

The demand for online recruitment and job placement resources significantly increased over the last five to ten years: the share of companies who use the internet to recruit personnel has grown from $60 \%$ in 2010 to $76 \%$ in 2010-2014, while the share of job seekers using the internet to find employment in 20062014 increased from 13\% to $49 \%$. On the whole, such practices can be considered established and routine on the Russian labour market, i.e., it would be more correct to speak about the evolution of (as opposed to a revolution in) recruiting. At the same time, the internet did not replace the main channel for finding jobs and personnel alike (i.e., friends and acquaintances or social networks), but rather supplemented it. All labour market players use recruitment platforms not so much to cut costs (as maintains [Autor, 2001]), as to find better workers and better jobs [Sakurai, Okudo, 2015].

Mutual complementarity was discovered between personnel hired via the internet, and vacancies typically filled this way. Online mechanisms are most commonly used by private Russian-owned trading and financial companies paying good wages and enjoying a healthy financial position, located in medium and large cities. The internet is more often used to recruit professionals than lower-skilled workers (who are not sufficiently represented online), or managers (hiring them involves a comprehensive assessment of candidates and requires personal contact). The high demand for online recruiting resources by trading firms can be explained by the fact that such jobs do not require specific skills, so companies can use mechanisms for the automatic screening of applicants. Public companies (who tend to lag in this area) remain highly inertial regarding the application of innovative techniques and work procedures. Individuals with higher or secondary professional education residing in Moscow, St. Petersburg, and regional capitals use the internet to find jobs more actively than others do, which increases their chances of finding suitable employment. 


\section{Table 5. Factors Affecting the Use of the Internet to Find Jobs (Model 1), and the Probability of Finding Them (Model 2) (probit model)}

\begin{tabular}{|c|c|c|}
\hline \begin{tabular}{lc|} 
Explanatory variables & Dependent variable \\
\end{tabular} & $\begin{array}{l}\text { Use of the internet to find } \\
\text { jobs }\end{array}$ & $\begin{array}{c}\text { Probability of finding } \\
\text { a job }\end{array}$ \\
\hline & (1) & (2) \\
\hline Use of the internet to find a job & & $0.0454^{* *}$ \\
\hline \multicolumn{3}{|l|}{ Socio-demographic characteristics } \\
\hline Age & 0.0031 & $-0.0093^{*}$ \\
\hline Age (square) & $-0.0001^{\star *}$ & 0.0001 \\
\hline Gender $($ female $=1)$ & -0.0131 & -0.0087 \\
\hline Family status (married $=1$ ) & $0.0508^{\star *}$ & 0.0115 \\
\hline Number of children younger than 18 & $-0.0215^{*}$ & 0.0008 \\
\hline Student & $0.1047^{\star \star}$ & $-0.0886^{\star *}$ \\
\hline Pensioner & -0.0480 & 0.0740 \\
\hline \multicolumn{3}{|l|}{ Labor market status } \\
\hline Unemployment level in the region & 0.0180 & -0.0403 \\
\hline Registered at the public employment service & $-0.0579^{*}$ & $0.1287^{\star *}$ \\
\hline Unemployed for more than a year & -0.0641 & 0.0526 \\
\hline \multicolumn{3}{|l|}{ Education (below secondary) } \\
\hline Secondary & $0.1305^{\star \star}$ & -0.0100 \\
\hline Vocational, below secondary & 0.0018 & 0.0356 \\
\hline Vocational secondary & $0.0730^{\star *}$ & 0.0410 \\
\hline Secondary professional & $0.2199^{* *}$ & 0.0219 \\
\hline Tertiary & $0.3091^{\star *}$ & -0.0329 \\
\hline Post graduate & $0.3317^{\star \star}$ & -0.0806 \\
\hline \multicolumn{3}{|l|}{ Place of residence (Moscow, St. Petersburg) } \\
\hline Regional capital & $-0.1158^{\star *}$ & -0.0071 \\
\hline Regional center & $-0.2255^{\star *}$ & 0.0214 \\
\hline Town & $-0.3257^{\star *}$ & 0.0462 \\
\hline Village & $-0.3902^{\star *}$ & 0.0320 \\
\hline \multicolumn{3}{|l|}{ Federal District (Central) } \\
\hline Southern & -0.1100 & 0.1307 \\
\hline North-Western & -0.0264 & 0.0546 \\
\hline Far Eastern & -0.0394 & $0.2129^{*}$ \\
\hline Siberian & -0.1121 & 0.1719 \\
\hline Urals & 0.0139 & 0.0939 \\
\hline Volga & $-0.1093^{\star}$ & 0.0969 \\
\hline North Caucasus & $-0.3827^{\star}$ & 0.4378 \\
\hline \multicolumn{3}{|l|}{ Year (2010) } \\
\hline 2011 & 0.0350 & $-0.0649^{*}$ \\
\hline 2012 & $0.1250^{\star *}$ & -0.0862 \\
\hline 2013 & $0.1942^{\star *}$ & $-0.1062^{\star}$ \\
\hline 2014 & $0.2212^{\star \star}$ & \\
\hline Constant & -0.2054 & 0.5252 \\
\hline Number of observations & 4096 & 3565 \\
\hline Pseudo $\mathrm{R}^{2}$ & 0.2121 & 0.0271 \\
\hline
\end{tabular}

The obtained results allow us to map areas where online recruitment mechanisms are likely to develop further. Firstly, the increased use of such functionality by older (due to the ageing of the current audience) and less educated job seekers will be fuelled by the advancement of the mobile internet, and the adaptation of online services for use on smartphones. Secondly, public companies paying lower wages will be more actively recruiting low-skilled workers via the internet, due to development of, and easier access to relevant resources. Thirdly, the digitalization of conventional recruitment channels is likely to continue, primarily due to advertising in mass media and the public employment service's and private recruiting agencies' efforts. Relevant good examples include the online vacancy database at TrudVsem.ru and similar portals maintained by regional employment services. Even such a popular source of information about jobs as relatives and acquaintances is changing due to the advancement of social networks and online messenger services.

This paper was written in the scope of the "Inequality on the Labour Market" project implemented by the Laboratory for Labour Market Studies in the framework of the HSE Basic Research Programme. 


\section{References}

Ancor (2014) Rekrutment $v$ kompaniyakh Rossii. Vzglyad rabotodatelei [Recruitment in the companies of Russia. The view of employers]. Moscow: Ancor. Available at: https://ancor.ru/f/1/client/Recruitment\%20v\%20Rossii.pdf, accessed 17.02.2016 (in Russian).

Autor D.H. (2001) Wiring the labour Market. Journal of Economic Perspectives, vol. 15, no 1, pp. 25-40.

Avraamova E., Gurkov I., Karpukhina G., Levinson A., Mikhailyuk M., Polushkina E., Stuchevskaya O. (2006) Trebovaniya rabotodatelei $k$ sisteme professional'nogo obrazovaniya [Requirements of employers to the vocational education system] (eds. T. Klyachko, G. Krasnova), Moscow: MAKS Press (in Russian).

Beard T.R., Ford G.S., Saba R.P., Seals Jr. R.A. (2012) Internet use and job search. Telecommunications Policy, vol. 36, no 4, pp. 260-273.

Brenčič V., Norris J.B. (2012) Employers' On-Line Recruitment and Screening Practices. Economic Inquiry, vol. 50, no 1, pp. 94-111.

Denisova I., Lazareva O. (2006) Naem ili pereobuchenie: opyt rossiiskikh predpriyatii [Recruitment or retraining: The experience of Russian enterprises] (HSE Preprint WP3/2006/11). Moscow: HSE (in Russian).

Fountain C. (2005) Finding a Job in the Internet Age. Social Forces, vol. 83, no 3, pp. 1235-1262.

Garg R., Telang R. (2012) To be or not to be linked on LinkedIn: Job search online social network (Heinz College Working Paper, June 2012), Pittsburgh, PA: Carnegie Mellon University.

Gimpelson V., Lukyanova A. (2006) Byt' byudzhetnikom v Rossii: udachnyi vybor ili neschastnaya sud'ba? [To be a budgetary in Russia: A successful choice or an unhappy fate?]. Ekonomicheskii zhurnal Vysshei shkoly ekonomiki [HSE Economic Journal], vol. 10, no 4, pp. 557-589 (in Russian).

HSE (2016) Indikatory informatsionnogo obshchestva: 2016. Statisticheskii sbornik [Information Society Indicators: 2016. Data Book], Moscow: HSE (in Russian).

Jansen B.J., Jansen K.J., Spink A. (2005) Using the web to look for work: Implications for online job seeking and recruiting. Internet Research, vol. 15, no 1, pp. 49-66.

Jovanovic B. (1979) Job Matching and the Theory of Turnover. Journal of Political Economy, vol. 87, no 5, pp. 972-990.

Kuhn P. (2014) The Internet as a labour market matchmaker. IZA World of Labor, no 18. Available at: https://wol.iza.org/ uploads/articles/18/pdfs/internet-as-a-labor-market-matchmaker.pdf? $\mathrm{v}=1$, accessed 17.02.2016.

Kuhn P., Mansour H. (2014) Is Internet Job Search Still Ineffective? The Economic Journal, vol. 124, no 581, pp. 12131233.

Kuhn P., Skuterud M. (2000) Job search methods: Internet versus traditional. Monthly Labour Review, no 123, pp. 3-11.

Kuhn P., Skuterud M. (2004) Internet Job Search and Unemployment Durations. American Economic Review, vol. 94, no 1, pp. 218-232.

Kuznetsova I., Gosteva S., Gracheva G. (2008) Metodologiya i praktika statisticheskogo izmereniya innovatsionnoi deyatel'nosti v ekonomike Rossii: sovremennye tendentsii [Methodology and practice of statistical measurement of innovative activity in the Russian economy: Current trends]. Voprosy statistiki, no 5, pp. 30-46 (in Russian).

Marchal E., Mellet K., Rieucau G. (2005) Job Board Toolkits: Internet Matchmaking and the Transformation of HelpWanted Ads (Centre d'études de l'emploi Working Paper no 50), Noisy-le-Grand: Centre d'études de l'emploi.

Nakamura A.O., Shaw K.L., Freeman R.B., Nakamura E., Pyman A. (2009) Jobs Online. Studies of labour Market Intermediation (ed. D.H. Autor), Cambridge, MA: National Bureau of Economic Research, pp. 27-65.

Naryshkina A. (2007) Modelirovanie protsessa poiska raboty pri perekhode ot ucheby $k$ rabote [Modeling the process of job search in the transition from study to work] (HSE Preprint WP15/2007/03), Moscow: HSE (in Russian).

OECD, Eurostat (2005) Oslo Manual. Guidelines for Collecting and Interpreting Innovation Data (3 ${ }^{\text {rd }}$ ed.), Paris: OECD, Eurostat.

Roshchin S., Markova K. (2004) Vybor kanalov poiska raboty na rossiiskom rynke truda [Choice of job search channels on the Russian labour market] (EERC Preprint 04/05), Moscow: Economics Education and Research Consortium (in Russian).

Roshchin S., Travkin P. (2015) Dopolnitel'noe professional'noe obuchenie na rossiiskikh predpriyatiyakh [JobRelated Training on Russian Enterprises]. Zhurnal Novoi ekonomicheskoi assotsiatsii [Journal of the New Economic Association], no 2, pp. 150-171 (in Russian).

Rosstat (2015a) Vyborochnoe nablyudenie po voprosam ispol'zovaniya naseleniem informatsionnykh tekhnologii i informatsionno-telekommunikatsionnykh setei za $2014 \mathrm{~g}$. [Selective observation on issues of population use of information technologies and information and telecommunications networks for 2014], Moscow: Rosstat (in Russian).

Rosstat (2015b) Trud i zanyatost' v Rossii: 2015 [Labor and Employment in Russia: 2015], Moscow: Rosstat. Available at: http://www.gks.ru/free_doc/doc_2015/trud15.pdf, accessed 07.04.2016 (in Russian).

Sakurai K., Okudo Y. (2015) Job Seeker Trends 2015, Boston, MA: Boston Consulting Group.

Sharunina A. (2016) Gde byudzhetniku zhit' khorosho: analiz mezhsektornykh razlichii v oplate truda v regionakh Rossii [Where Do Public Workers Live Well? Public-Private Wage Gaps in Russia’s Regions]. Zhurnal Novoi ekonomicheskoi assotsiatsii [Journal of the New Economic Association], no 2, pp. 105-128 (in Russian).

Stevenson B. (2003) The Internet, Job Search, and Worker Mobility, Stanford, CA: Stanford University.

Stevenson B. (2008) The Internet and Job Search (NBER Working Paper 13886), Cambridge, MA: National Bureau of Economic Research.

Stuken T. (2008) Effektivnost' ispol'zovaniya sotsial'nykh setei pri trudoustroistve [Efficiency of the use of social networks in job placement]. Vestnik Omskogo universiteta (Ekonomika) [Herald of Omsk University (Series "Economics")], no 3, pp. 70-75 (in Russian).

Suvankulov F., Lau Chi Keung M., Ho Chi Chau F. (2012) Job search on the internet and its outcome. Internet Research, vol. 22, no 3, pp. 298-317.

Tikhonova I. (2015) Novye vozmozhnosti rekrutinga XXI veka [New opportunities for recruiting the XXI century]. Nauchnyi al'manakh (Sotsiologicheskie nauki) [Scientific almanac (Sociological sciences)], no 7, pp. 1277-1280 (in Russian).

Weinburger C.M., Strider S.H., Vengrouskie E.F. (2015) Social Media Job Searches and the Strength of Veteran Ties. Human Resource Management Research, vol. 5, no 6, pp. 133-153.

Yakubovich V. (2002) Instituty, sotsial'nye seti i rynochnyi obmen: Podbor rabotnikov i rabochikh mest v Rossii [Institutions, social networks and market exchange: Selection of workers and jobs in Russia]. Ekonomicheskaya sotsiologiya: Novye podkhody $k$ institutsionalnomu $i$ setevomu analizu [Economic Sociology: New Approaches to Institutional and Network Analysis] (ed. V.V. Radaev), Moscow: ROSSPEN, pp. 210-251 (in Russian). 


\title{
Relationship between Knowledge Management and Managerial Skills: The Role of Creative Thinking
}

\author{
Ali Shamsi \\ PhD candidate, Faculty of Education Sciences and Psychology, alishamsi34@yahoo.com \\ University of Isfahan, Isfahan Province, Isfahan, P.O. Box 146, Daneshgah Street, Isfahan, 81746-73441, Iran
}

\begin{abstract}
$\mathrm{K}$
nowledge management is one of the most important issues that must be considered by the managers of organizations, especially educational organizations. It is aimed at finding new viewpoints about learning, creating knowledge, and developing internal and external competences. This paper investigates the relationship between managerial skills and knowledge management mediated by creative thinking. The analysis is based on a survey of several hundred managers and teachers of Isfahan secondary schools. The research employs a step-by-step regression analysis and structural equation modeling.
\end{abstract}

Abstract

Keywords: knowledge management; creative thinking; management skills; technical skills; social skills; cognitive skills; education.
Based on the results of the calculations, a significant correlation was established between the three main variables of the study: managerial skills, knowledge management, and creative thinking. Thus, the hypotheses on the close relationship between these factors were confirmed. The quality of knowledge management is affected primarily by social skills and the ability to enforce creative thinking in daily life. The findings suggest the need for establishing an organizational environment that fosters the development of knowledge management skills and removes barriers impeding this process.

Citation: Shamsi A. (2017) The Relationship between Knowledge Management and Managerial Skills: The Role of Creative Thinking. Foresight and STI Governance, vol. 11, no 4, pp. 44-51. DOI: $10.17323 / 2500-2597.2017 .4 .44 .51$ 
$\mathrm{E}$ ducational institutions play a critical and tangible role in the molding and development of society. In order to achieve the cultural, social, and economic goals set before them, these institutions must develop their resource base, including the training of teachers and competent managers. In this sense, for the realization of such purposes, attractive environments must be created and reinforced by competent managers and staff.

One of the most important issues faced by the manager of any organization, of especially educational organizations, is knowledge management. One must note that the availability of swathes of knowledge can only be considered beneficial if it is considered a dynamic asset, which allows for building up organizational capacities and expanding opportunities for development [French, Bill, 2013].

As mentioned by [Smith, 2004; Shaker, 2007; Hafez, Alghatas, 2007], the purposes of knowledge management include finding new viewpoints about learning, creating knowledge, and developing internal and external competences. This can be better fulfilled if a manager has a set of certain skills and improves these skills continuously until he/she can engage with topics related to knowledge management at his/her organization. From the viewpoint of Robert Katz [Katz, 1974], management skills can be separated into three categories: cognitive, social, and technical.

Technical skills involve the possession of knowledge, special methods and operational procedures, and competence in analyzing specialized subjects [Rezaiean, 2003]. Social skills involve being able to work with, understand, and motivate an individual or a group [Alagheband, 2005]. Finally, cognitive skills involve abstract thinking, the ability to look at the big picture as well as see relationships within an organization and its outside environment [Robbins, 2010].

The main component of an organization's knowledge lies within its staff's minds. This organizational asset includes their skills, abilities, and practical experience, which is acquired through study and work. Now, questions arise such as, for example, 'How are these skills, abilities, and practical experiences transferred from one source to another?'; 'Can we use knowledge management to prevent the loss of this asset?'

According to Buzan, creative thinking is the ability to look at a problem from a new angle, to rethink one's position on one issue or another [Buzan, 2003]. It is the process of breaking down and building up our knowledge about an issue while gaining new insights about it. The theoretical model of our research is presented in Figure 1.

According to the theoretical model of research, knowledge management is the dependent variable, the management skills are the independent variable (including cognitive, social, and technical skills), while creative thinking acts as a mediator. To investigate management skills, knowledge management, and creative thinking, this study relies upon the approaches presented in [Katz, 1974; Nonaka, Takeuchi, 1995; Torrance, 1980], respectively.

\section{Literature Review and Hypotheses Formulation}

By investigating creative thinking styles, Hara and Stranberge [Hara, Stranberge, 2009] concluded that the observed subjects who employ original ways of thinking had better creative function. El Sabaa [El Sabaa, 2011] posits that among the various management skills, social skills have the greatest impact upon one's managerial approach when compared with technical and cognitive skills.

Wiig [Wiig, 2000] performed a comprehensive study on knowledge management at public organizations and claimed that systematic knowledge management was an important problem-solving tool. Such a system raises an organization's effectiveness in resolving economic and social problems.

Che Rusuli et al. [Che Rusuli et al., 2013] conducted a related study entitled "Linkage Between Knowledge Management Practices Towards Library User's Satisfaction at Malaysian University Libraries", and the results indicated that there was a strong relationship between knowledge management function and library users' satisfaction. By registering data and preserving knowledge, the internal services of the library improved and costs fell. The improvement of information technology stations facilitated knowledge management deployment at university libraries and increased users' satisfaction.

Figure 1. Theoretical Model of Research

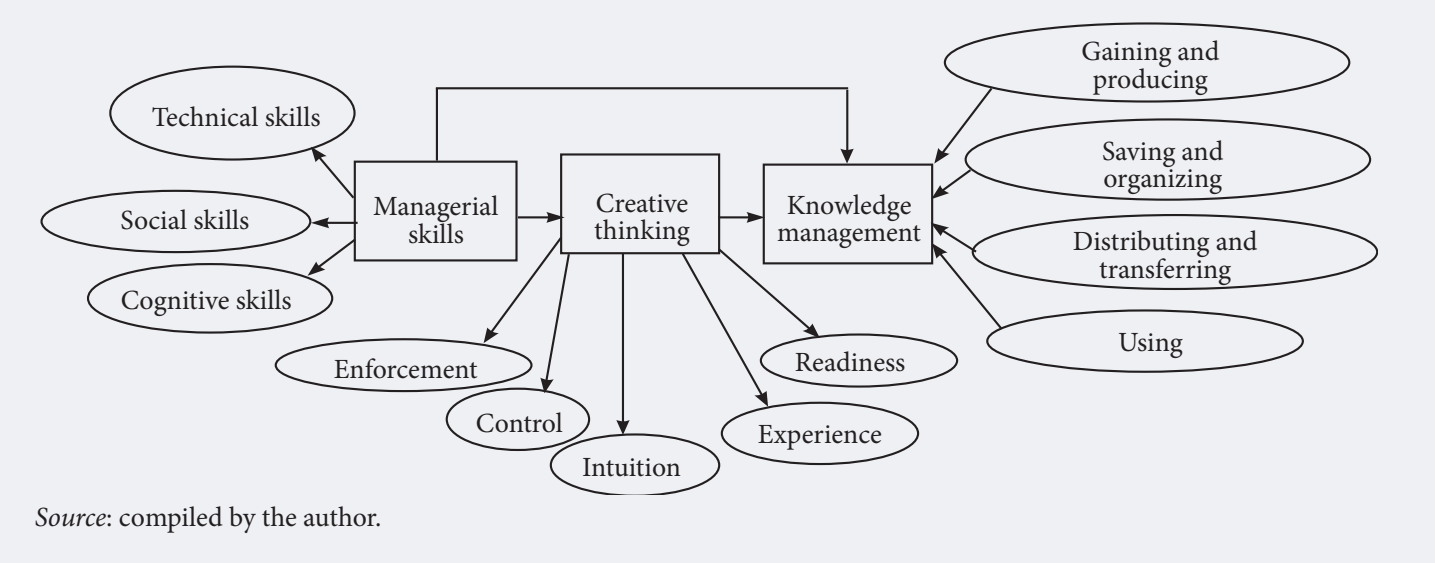


Khodayari [Khodayari, 2006] conducted a study on boys' secondary schools in Tehran, which showed that those administrators with better creative thinking skills could more successfully resolve educational and training issues. In another study on Iranian universities, the relationship between employees' cognitive, social, and technical skills and achieved results was analyzed by Afshari, Honary, and Ghafori [Afshari et al., 2013]. According to the management reserve (MR) index, highest priority was given to social skills, which are necessary for all types of administrative tasks (highest MR value), then cognitive and technical skills follow, respectively. Ghazizade and Atayee [Ghazizade, Atayee, 2013] design an effective path for an organization through the process of knowledge management. The results demonstrated that a key aspect of knowledge management involves transforming technical knowledge into explicit knowledge based on practical experience. Furthermore, this leads to higher levels of effectiveness at organizations. This study delves into methods of knowledge identification and the exploitation of such knowledge by analyzing the needs, tools, and methods of knowledge acquisition. Ameri and Areze [Ameri, Areze, 2014] studied the relationship between knowledge management and the communication skills of managers at Iranian sports schools. The results of this research showed that there is a significant and positive relationship between communication skill indices and the creation and transfer aspects of knowledge management; therefore, managers must improve their communication skills until this leads to the increased creativity of personnel and improved development of the organization, including more effective knowledge management skills.

In a similar study by Farahi [Farahi, 2014], the author surveyed the relationship between skills and job performance in management roles among scientific council members of NAJA (Islamic Republic of Iran Police). The study shows that the acquisition of necessary skills qualitatively depends upon employees meeting their professional obligations, the absence of this negatively impacts one's career.

According to the aforementioned studies, we may conclude that, in managers' view, social skills (teamwork, the ability to understand and motivate others), technical skills (introducing feedback, organizing and coordinating work, computer skills), and communication skills (rhetoric, showing emotion and cooperation with others) play a great role that one's position and job description. Managers possessing the essential managerial skills enjoy greater motivation and satisfaction, and perform more effectively. For example, those managers who are familiar with information technology and computers, more rapidly and effectively solve problems connected with information and data collection.

The purpose of this study is to investigate the relationship between managerial skills and knowledge management mediated by creative thinking. Accordingly, the following hypotheses have been drawn:

1) There is a significant relationship between managerial skills and knowledge management.

2) There is a significant relationship between creative thinking and knowledge management.

3) There is a significant relationship between managerial skills and creative thinking.

4) The improvement of knowledge management processes depends upon managerial skills.

5) The improvement of knowledge management depends upon creative thinking.

6) Managerial skills facilitate the development of creative thinking.

7) The proposed conceptual model can be applied in practice.

\section{Methodology}

In this article, the author employs an applied approach, which describes the situation and analyzes relationships between the dependent and independent variables. In this research, knowledge management acts as the dependent variable and management skills are the independent variable. Meanwhile, managers' creative thinking acts as a mediator between the dependent and independent variables. The author then considers the mediation role played by creative thinking using structural equation modeling and a step-bystep regression analysis.

In this research, the sample includes managers and teachers from Isfahan school districts in 2015-2016, whose numbers amount to 377 and 5,981, respectively. The sampling method is random and proportionate to the sample size of managers and teachers and is calculated according to Cochran's sample size formula [Cochran, 1977] as the following (see parameter details in Table 1):

$\mathrm{n}=\frac{\mathrm{Nt}^{2} \mathrm{pq}}{\mathrm{Nd}^{2}+\mathrm{t}^{2} \mathrm{pq}}$.

Table 1. Parameters for Determining Sample Size

\begin{tabular}{|l|l|l|l|}
\hline \multicolumn{1}{|c|}{ Parameters } & \multicolumn{1}{c|}{ Code } & \multicolumn{1}{c|}{ Managers } & \multicolumn{1}{|c|}{ Teachers } \\
\hline Sample size & $\mathrm{n}$ & 185 & 360 \\
\hline Population & $\mathrm{N}$ & 377 & 5981 \\
\hline Acceptable confidence level & $\mathrm{t}$ & 1.96 & 1.96 \\
\hline Share in total sample, which possesses the studied characteristics & $\mathrm{p}$ & 0.5 & 0.5 \\
\hline Share from total population with none of the studied attributes & $\mathrm{q}$ & 0.5 & 0.5 \\
\hline Desirable probable accuracy or confidence interval & $\mathrm{d}$ & 0.05 & 0.05 \\
\hline Source: compiled by the author. & & \\
\hline
\end{tabular}


Table 2. Average Value and Standard Deviation for Scores of Knowledge Management, Creative Thinking, and Management Skills

\begin{tabular}{|l|c|c|}
\hline \multicolumn{1}{|c|}{$\begin{array}{c}\text { Statistical indices for } \\
\text { variables }\end{array}$} & Mean & $\begin{array}{c}\text { Standard } \\
\text { deviation }\end{array}$ \\
\hline Knowledge management & 0.63 & 4.05 \\
\hline Creative thinking & 0.45 & 3.94 \\
\hline Management skills & 0.50 & 4.38 \\
\hline Source: compiled by the author. \\
\hline
\end{tabular}

Table 4. The Correlation Coefficient between Creative Thinking and Knowledge Management

\begin{tabular}{|l|l|l|l|}
\hline \multicolumn{1}{|c|}{ Statistical index } & \multicolumn{1}{c|}{$\mathbf{r}$} & \multicolumn{1}{c|}{$\mathbf{r}^{2}$} & \multicolumn{1}{c|}{ Sig. } \\
\hline Creative thinking & 0.32 & 0.10 & 0.001 \\
\hline Readiness & 0.21 & 0.04 & 0.010 \\
\hline Experience & 0.27 & 0.07 & 0.001 \\
\hline Intuition & 0.18 & 0.03 & 0.032 \\
\hline Control & 0.25 & 0.06 & 0.002 \\
\hline Enforcement & 0.28 & 0.08 & 0.001 \\
\hline $\begin{array}{l}\text { Notes: } \mathrm{r}-\text { correlation coefficient; } \mathrm{r}^{2}-\text { correlation coefficient square; } \\
\text { Sig. }- \text { significance level. } \mathrm{p}<0.05 \\
\text { Source: compiled by the author.. }\end{array}$ \\
\hline
\end{tabular}

Table 3. The Correlation Coefficient between Management Skills and Knowledge Management

\begin{tabular}{|l|l|l|l|}
\hline \multicolumn{1}{|c|}{ Statistical index } & \multicolumn{1}{c|}{$\mathbf{r}$} & $\mathbf{r}^{2}$ & \multicolumn{1}{c|}{ Sig. } \\
\hline Management skills & 0.84 & 0.71 & 0.001 \\
\hline Technical skills & 0.77 & 0.59 & 0.001 \\
\hline Social skills & 0.81 & 0.65 & 0.001 \\
\hline Cognitive skills & 0.79 & 0.63 & 0.001 \\
\hline $\begin{array}{l}\text { Notes: } \mathrm{r}-\text { correlation coefficient; } \mathrm{r}^{2}-\text { correlation coefficient square; } \\
\text { Sig. }- \text { significance level. } \mathrm{p}<0.05 \\
\text { Source: compiled by the author. }\end{array}$ \\
\hline
\end{tabular}

\section{Table 5. The Correlation Coefficient between} Management Skills and Creative Thinking

\begin{tabular}{|c|c|c|c|}
\hline Statistical index & $\mathbf{r}$ & $\mathbf{r}^{2}$ & Sig. \\
\hline Management skills & 0.30 & 0.09 & 0.001 \\
\hline Technical skills & 0.33 & 0.11 & 0.001 \\
\hline Social skills & 0.28 & 0.07 & 0.001 \\
\hline Cognitive skills & 0.23 & 0.05 & 0.001 \\
\hline \multicolumn{4}{|c|}{$\begin{array}{l}\text { Notes: } \mathrm{r}-\text { correlation coefficient; } \mathrm{r}^{2}-\text { correlation coefficient square; } \\
\text { Sig. }- \text { significance level. } \mathrm{p}<0.05\end{array}$} \\
\hline \multicolumn{4}{|l|}{ Source: compiled by the author. } \\
\hline
\end{tabular}

According to the calculations produced by the aforementioned formula, 185 managers and 370 teachers were selected as a statistical sample.

For investigating management skills, Robert Katz' theory-based, established questionnaire was used [Katz, 1974]. This questionnaire includes 36 questions on the Likert five-step scale whose reliability coefficient was calculated at 0.97 by using Cronbach's Alpha coefficient.

For investigating knowledge management, a questionnaire based on Takeuchi and Nonaka's model [Nonaka, Takeuchi, 1995] was used. This questionnaire includes 37 questions on the Likert five-step scale, and its reliability coefficient was calculated at 0.97 by using Cronbach's Alpha coefficient. Teachers from the sample served as respondents.

For the creative thinking variable, a standard questionnaire based on Torrance's theory [Torrance, 1980] was employed. It includes 20 questions, and its reliability coefficient is 0.88 .

These questionnaires were given to consultants and experts for revisions, in order make them more relevant. To calculate the reliability of the questionnaires, Cronbach's alpha coefficient was used. Education experts from universities underscored the validity of the three questionnaires.

One-hundred-eighty-five questionnaires relevant to creative thinking were distributed among the sample of managers who responded to 174, which were used in this analysis. For both management skills and knowledge management, 370 questionnaires were distributed among the sample of teachers. Of these, 360 questionnaires were answered and used in the analysis.

\section{Results}

The results of the descriptive statistics analysis showed that the highest percentage of responses were given by managers between 46 and 55 years of age with 20 years' experience in the humanities and a BA/BS degree, while the majority of teachers were between 36 to 45 years of age with the relevant experience and degree. Table 2 shows the main indices for the three variables of this study.

\section{Deductive Statistics}

In this section, the deductive findings of this research confirm or refute the proposed hypotheses.

Table 3 shows that the correlation coefficient between management skills and knowledge management is significant $(\mathrm{r}=0.84)$. On the basis of the determination coefficient $\left(\mathrm{r}^{2}\right)$, variance between management skills and knowledge management amounts to $71.2 \%$, so Hypothesis 1, which states that there is a relationship between management skills and knowledge management is confirmed.

The findings of Table 4 show that the correlation coefficient between creative thinking and knowledge management is significant $(\mathrm{r}=0.328)$. 


\section{Table 6. Coefficients from Multiple Regression of Certain Components of Management Skills and Knowledge Management $(p<0.01)$}

\begin{tabular}{|c|c|c|c|c|c|c|}
\hline \multirow[b]{2}{*}{$\begin{array}{l}\text { Criterion - } \\
\text { Knowledge } \\
\text { management }\end{array}$} & \multicolumn{6}{|c|}{ Statistical indexes } \\
\hline & $\begin{array}{l}\text { Independent } \\
\text { variable }\end{array}$ & $\begin{array}{l}\text { Multiple } \\
\text { regression } \\
\text { coefficient }\end{array}$ & $\begin{array}{l}\text { Multiple regression } \\
\text { coefficient squared }\end{array}$ & $\begin{array}{l}\text { Adjusted multiple } \\
\text { regression coefficient } \\
\text { squared }\end{array}$ & F-Coefficient & $\begin{array}{l}\text { Significance } \\
\text { level }\end{array}$ \\
\hline Step 1 & Social skills & 0.81 & 0.65 & 0.65 & 245.37 & 0.001 \\
\hline Step 2 & $\begin{array}{l}\text { Social skills } \\
\text { Technical skills }\end{array}$ & 0.83 & 0.69 & 0.69 & 145.29 & 0.001 \\
\hline Step 3 & $\begin{array}{l}\text { Social skills } \\
\text { Technical skills } \\
\text { Cognitive skills }\end{array}$ & 0.84 & 0.71 & 0.70 & 103.75 & 0.001 \\
\hline
\end{tabular}

\section{Table 7. Table of the $\boldsymbol{\beta}$-coefficient as an Indicator of the Correlation between Certain} Dimensions of Management Skills and Knowledge Management $(\mathbf{p}<0.05)$

\begin{tabular}{|c|c|c|c|c|c|c|}
\hline \multirow{3}{*}{$\begin{array}{c}\text { Criterion - } \\
\text { Knowledge } \\
\text { management }\end{array}$} & \multicolumn{6}{|c|}{ Statistical indexes } \\
\hline & \multirow[t]{2}{*}{ Independent variable } & \multicolumn{2}{|c|}{ Non-standard $\beta$ coefficients } & \multirow{2}{*}{$\begin{array}{c}\text { Standard } \\
\beta \text { coefficients }\end{array}$} & \multirow[t]{2}{*}{ t-coefficient } & \multirow{2}{*}{$\begin{array}{c}\text { Significance } \\
\text { level }\end{array}$} \\
\hline & & $\beta$ & Standard error & & & \\
\hline \multirow[t]{2}{*}{ Step 1} & (Constant) & 0.26 & 0.24 & - & 0.08 & 0.282 \\
\hline & Social skills & 0.87 & 0.05 & 0.81 & 15.66 & 0.001 \\
\hline \multirow[t]{3}{*}{ Step 2} & (Constant) & -0.34 & 0.27 & - & -1.25 & 0.210 \\
\hline & Social skills & 0.57 & 0.09 & 0.53 & 6.25 & 0.001 \\
\hline & Technical skills & 0.44 & 0.11 & 0.34 & 4.01 & 0.001 \\
\hline \multirow[t]{4}{*}{ Step 3} & (Constant) & -0.48 & 0.27 & - & -1.76 & 0.079 \\
\hline & Social skills & 0.36 & 0.11 & 0.33 & 3.03 & 0.003 \\
\hline & Technical skills & 0.34 & 0.11 & 0.26 & 2.97 & 0.003 \\
\hline & Cognitive skills & 0.34 & 0.12 & 0.29 & 2.64 & 0.009 \\
\hline
\end{tabular}

\section{Table 8. Multiple Regression Coefficient of Creative Thinking Dimensions with Knowledge Management $(p<0.05)$}

\begin{tabular}{|l|l|l|l|l|l|l|}
\hline \multirow{2}{*}{$\begin{array}{c}\text { Criterion - } \\
\text { Knowledge } \\
\text { management }\end{array}$} & $\begin{array}{c}\text { Independent } \\
\text { variable }\end{array}$ & $\begin{array}{c}\text { Multiple } \\
\text { regression } \\
\text { coefficient }\end{array}$ & $\begin{array}{c}\text { Multiple regression } \\
\text { coefficient squared }\end{array}$ & $\begin{array}{c}\text { Adjusted multiple } \\
\text { regression coefficient } \\
\text { squared }\end{array}$ & F-coefficient & $\begin{array}{c}\text { Significance } \\
\text { level }\end{array}$ \\
\hline Step 1 & Enforcement & 0.31 & 0.09 & 0.09 & 14.81 & 0.001 \\
\hline Source: compiled by the author.
\end{tabular}

Table 9. Variable from Regression Equation for Anticipating Knowledge Management with Creative Thinking Dimensions $(\mathbf{p}<0.05)$

\begin{tabular}{|c|c|c|c|}
\hline Criterion & $\beta$ & T-statistics & $\begin{array}{c}\text { Significance } \\
\text { level }\end{array}$ \\
\hline Readiness & 0.08 & 0.94 & 0.346 \\
\hline Experience & 0.015 & 1.56 & 0.120 \\
\hline Intuition & 0.04 & 0.46 & 0.641 \\
\hline Control & 0.11 & 1.11 & 0.267 \\
\hline \multicolumn{4}{|c|}{$\begin{array}{l}\text { Note: Analysis is taken in one step. } \\
\text { Criterion - knowledge management }\end{array}$} \\
\hline \multicolumn{4}{|c|}{ Source: compiled by the author. } \\
\hline
\end{tabular}

Table 10. The $\boldsymbol{\beta}$-coefficient as an Indicator of the Correlation between Creative Thinking and Knowledge Management $(\mathbf{p}<0.05)$

\begin{tabular}{|l|l|c|l|l|l|}
\hline \multicolumn{7}{|c|}{ Statistical indexes } \\
\hline $\begin{array}{l}\text { Independent } \\
\text { variable }\end{array}$ & $\begin{array}{c}\text { Non - standard } \\
\beta \text {-coefficient }\end{array}$ & $\begin{array}{c}\text { Standard } \\
\beta \text {-coefficient }\end{array}$ & t-coefficient & $\begin{array}{c}\text { Significance } \\
\text { level }\end{array}$ \\
\cline { 2 - 3 } & $\begin{array}{c}\text { Standard } \\
\text { error }\end{array}$ & $\beta$ & & 0.45 & 0.001 \\
\hline (Constant) & 0.30 & 2.90 & - & 3.84 & 0.001 \\
\hline Enforcement & 0.30 & 0.07 & 0.31 & & \\
\hline $\begin{array}{l}\text { Note: Analysis is taken in one step. Criterion - creative thinking } \\
\text { Source: compiled by the author. }\end{array}$ \\
\hline
\end{tabular}


On the basis of the determination coefficient $\left(\mathrm{r}^{2}\right)$, the variance of creative thinking and knowledge management is $4.7 \%$. So, Hypothesis 2 , which states that there is a relationship between creative thinking and knowledge management is confirmed as well.

The findings of Table 5 show that the correlation coefficient between creative thinking and management skills is significant $(\mathrm{r}=0.308)$. Based on the determination coefficient $\left(\mathrm{r}^{2}\right)$, variance between creative thinking and management skills is $9.5 \%$. Therefore, Hypothesis 3 is confirmed.

Furthermore, Table 6 shows that social skills, technical skills, and cognitive skills are the best anticipators of knowledge management, respectively. Based on the results of a step-by-step regression analysis, the relationship between social, technical, and cognitive skills and knowledge management is significant. Therefore, on the basis of the coefficients characterizing social skills in particular and those with account of social, technical, and cognitive skills together determines $69.6 \%$ and $71.2 \%$, respectively, of the variance in knowledge management. The size of the F-coefficient is significant at $\mathrm{p}<0.01$, therefore, the regression can be used on the total sample.

The findings of Table 7 show that the $\beta$ coefficient increases knowledge management to 0.337 in lieu of a one-unit increase in social skills and the $\beta$ coefficient increases knowledge management to 0.292 in lieu of a one-unit increase in technical skills.

The forecast 'equation' for the fourth hypothesis in this research is introduced as follows:

Knowledge management $=(-0.489)+$ social skills $(0.362)+$ technical skills $(0.340)+$ cognitive skills $(0.341)$

As the findings of Table 8 show, the best anticipator of knowledge management studied in the first step of the regression is enforcement. Based on the step-by-step regression analysis results, the relationship between enforcement and knowledge management is significant. Therefore, the coefficient of enforcement is characterized by $9.8 \%$ variance in knowledge management. The F-coefficient observed at the $\mathrm{p}<0.01$ level is significant, so the regression can be used on the entire sample.

According to Table 9, the relationship between readiness, experience, intuition, and control is not significant. The findings of Table 10 show that the $\beta$ coefficient increases knowledge management up to 0.312 in lieu of a one-unit increase in enforcement.

The forecast equation of hypothesis 5 is as follows:

Knowledge management $=(2.900)+$ enforcement $(0.300)$

According to the findings of Table 11, the best anticipators of creative thinking are technical skills. Based on the step-by-step regression analysis, the relationship between technical skills and creative thinking is significant. So, technical skills specifies $10.5 \%$ variance in creative thinking. The F-coefficient with a value of $\mathrm{p}<0.01$ is significant, therefore, the regression is applied to the general sample.

According to Table 12, the relationship between cognitive and social skills and creative thinking is not significant.

According to the findings of Table 13, the $\beta$ coefficient increases creative thinking to 0.325 in lieu of a oneunit increase in technical skills.

The forecast equation of Hypothesis 6 is as follows:

Creative thinking $=(2.592)+$ technical skills (0.311)

Finally, we check Hypothesis 7 on the practical applicability of the model, assessing it based on goodnessof-fit.

To answer this question, chi-square statistics and other criteria relevant to the adaptability of the model in practice must be considered. All indices for goodness-of-fit are presented (see Tables 14 and 15).

\section{T value}

With the help of T criteria, the significance of model parameters is assessed. This statistic is obtained by calculating ratio of the parameter coefficient and standard deviation.

\begin{tabular}{|c|c|c|c|c|c|}
\hline & & Statistica & 1 indexes & & \\
\hline $\begin{array}{c}\text { Independent } \\
\text { variable }\end{array}$ & $\begin{array}{l}\text { Multiple } \\
\text { regression } \\
\text { coefficient }\end{array}$ & $\begin{array}{l}\text { Multiple } \\
\text { regression } \\
\text { coefficient } \\
\text { squared }\end{array}$ & $\begin{array}{c}\text { Adjusted } \\
\text { multiple } \\
\text { regression } \\
\text { coefficient } \\
\text { squared }\end{array}$ & $\underset{\text { coefficient }}{\text { F- }}$ & $\begin{array}{c}\text { Significance } \\
\text { level }\end{array}$ \\
\hline $\begin{array}{l}\text { Technical } \\
\text { skills }\end{array}$ & 0.32 & 0.10 & 0.10 & 17.80 & 0.001 \\
\hline
\end{tabular}

Table 12. Regression Variables Describing the Correlation between Creative Thinking and Management Skills $(\mathbf{p}<0.05)$

\begin{tabular}{|l|r|r|r|}
\hline \multicolumn{1}{|c|}{ Criterion } & $\beta$ & T-statistics & $\begin{array}{c}\text { Significance } \\
\text { level }\end{array}$ \\
\hline Social skills & 0.144 & 1.084 & 0.280 \\
\hline $\begin{array}{l}\text { Cognitive } \\
\text { skills }\end{array}$ & -0.077 & -0.582 & 0.562 \\
\hline $\begin{array}{l}\text { Note: Analysis is taken in one step. Criterion - creative } \\
\text { thinking } \\
\text { Source: compiled by the author. }\end{array}$ \\
\hline
\end{tabular}


Table 13. The $\beta$-coefficient as an Indicator of the Correlation between Management Skills and Creative Thinking $(\mathbf{p}<0.05)$

\begin{tabular}{|c|c|c|c|c|c|c|}
\hline \multirow{2}{*}{$\begin{array}{c}\text { Dependent } \\
\text { variable - } \\
\text { creative } \\
\text { thinking }\end{array}$} & \multicolumn{6}{|c|}{ Statistical indexes } \\
\hline & \multirow[t]{2}{*}{$\begin{array}{l}\text { Independent } \\
\text { variable }\end{array}$} & \multicolumn{2}{|c|}{$\begin{array}{l}\text { Non-standard } \\
\beta \text {-coefficient }\end{array}$} & \multirow[t]{2}{*}{$\begin{array}{c}\text { Standard } \\
\beta \text {-coefficient }\end{array}$} & \multirow[t]{2}{*}{ t-coefficient } & \multirow[t]{2}{*}{ Significance level } \\
\hline \multirow{3}{*}{ Step 1} & & Standard error & $\beta$ & & & \\
\hline & (Constant) & 2.59 & 0.32 & - & 8.01 & 0.001 \\
\hline & Enforcement & 0.31 & 0.07 & 0.32 & 4.21 & 0.001 \\
\hline
\end{tabular}

\section{$Z$ or $T=\frac{\text { parameter coefficient }}{\text { parameter standard deviation }}$}

To achieve statistical significance, this figure must be higher than 2 in the $\mathrm{T}$ test and higher than 1.96 in the $\mathrm{Z}$ test and/or less than -1.96. The estimated $\mathrm{T}$ value is higher than 2 and/or less than -2 for all variables. Therefore, all estimates are statistically significant. This model not only has goodness-of-fit, but all coefficients of the model are significant.

With regard to all processes completed in order to introduce a model (Figure 2), the following implicit model confirms the effect of management skills on knowledge management mediated by creative thinking. On the subject of the indirect effect of management skills on knowledge management (the path of management skills through creative thinking), path coefficients are multiplied by each other. The effect of management skills on knowledge management is significant, that is, the T value of each path is higher than 1.96 , which indicates the effect of management skills on knowledge management mediated by creative thinking.

\section{Discussion and Conclusion}

The purpose of this research was to analyze the three components of management skills and the knowledge management process mediated by creative thinking. The results of the descriptive analysis showed that, in the sample of managers, the highest number are between 46 and 55 years of age, with 20 years of service or more in the humanities and a BA/BS degree, while the sample of teachers are mostly between 36 and 45 years of age, with 20 years' experience or more in the humanities and a BA/BS degree. The results of the deductive analysis showed that there is a significant relationship between knowledge management and management skills ( $\mathrm{r}=0.844$ ), and the best anticipator of knowledge management is primarily one's social skills, while technical and cognitive skills follow. Based on the results of a step-by-step regression analysis, the relationship between cognitive, technical and social skills and knowledge management is found to be significant (first and fourth hypotheses). There is a positive and significant relationship ( $\mathrm{r}=0.327)$ between creative thinking and knowledge management. The best anticipator of knowledge management primarily is enforcement. Based on the step-by-step regression analysis results, the relationship between enforcement and knowledge management is significant, and the relationship of readiness, experience, intuition, and control with knowledge management is not significant (second and fifth hypotheses). The correlation coefficient between creative thinking and management skills is significant. Among the investigated variables in the regression, the second-best predictor after technical skills was creative thinking and based on the stepby-step regression analysis, the relationship between technical skills and creative thinking was significant, but the relationship between cognitive and social skills on the one hand and creative thinking on the other was not significant (third and sixth hypotheses). After analyzing the collected data, the results confirmed the effect of management skills on knowledge management mediated by creative thinking; therefore, the implicit model has goodness-of-fit.

Due to the obtained results of the current study, the strongest relationship was observed between management skills and knowledge management. Therefore, it seems essential that managers of educational

\begin{tabular}{|l|l|l|l|}
\hline \multicolumn{4}{|c|}{ Table 14. Indices of Model Adaptability } \\
\hline $\begin{array}{c}\text { Name of } \\
\text { index }\end{array}$ & $\begin{array}{c}\text { Standard } \\
\text { value of } \\
\text { index }\end{array}$ & $\begin{array}{c}\text { Index } \\
\text { value in } \\
\text { given } \\
\text { model }\end{array}$ & \multicolumn{1}{|c|}{ Conclusion } \\
\hline $\begin{array}{l}\text { dF to chi2 } \\
\text { ratio }\end{array}$ & - & 49.97 & It has goodness of fit \\
\hline P value & $>0.05$ & 0.346 & It has goodness of fit \\
\hline G F I & $>0.9$ & 1 & It has goodness of fit \\
\hline A G F I & $>0.9$ & 1 & It has goodness of fit \\
\hline N F I & $>0.9$ & 0.98 & It has goodness of fit \\
\hline C F I & $>0.9$ & 1 & It has goodness of fit \\
\hline R M S E A & $<0.1$ & 0.019 & It has goodness of fit \\
\hline Source: compiled by the author. & \\
\hline
\end{tabular}

Table 15. Direct Effects of Management Skills on Knowledge Management

\begin{tabular}{|l|l|l|l|}
\hline Survey of effect & \multicolumn{1}{|c|}{$\begin{array}{c}\text { Effect } \\
\text { coefficient }\end{array}$} & $\begin{array}{l}\text { Statistical } \\
\text { value of T }\end{array}$ & \multicolumn{1}{|c|}{ Conclusion } \\
\hline $\begin{array}{l}\text { Management } \\
\text { skill-creative } \\
\text { thinking }\end{array}$ & 0.30 & 8.54 & $\begin{array}{l}\text { Management skills } \\
\text { affect creative } \\
\text { thinking }\end{array}$ \\
\hline $\begin{array}{l}\text { Management } \\
\text { skills-knowledge } \\
\text { management }\end{array}$ & 0.26 & 5.80 & $\begin{array}{l}\text { Management skills } \\
\text { affect knowledge } \\
\text { management }\end{array}$ \\
\hline $\begin{array}{l}\text { Creative } \\
\text { thinking- } \\
\text { knowledge } \\
\text { management }\end{array}$ & 0.33 & 9.0 & $\begin{array}{l}\text { Creative thinking } \\
\text { affects knowledge } \\
\text { management }\end{array}$ \\
\hline Source: compiled by the author. & & \\
\hline
\end{tabular}




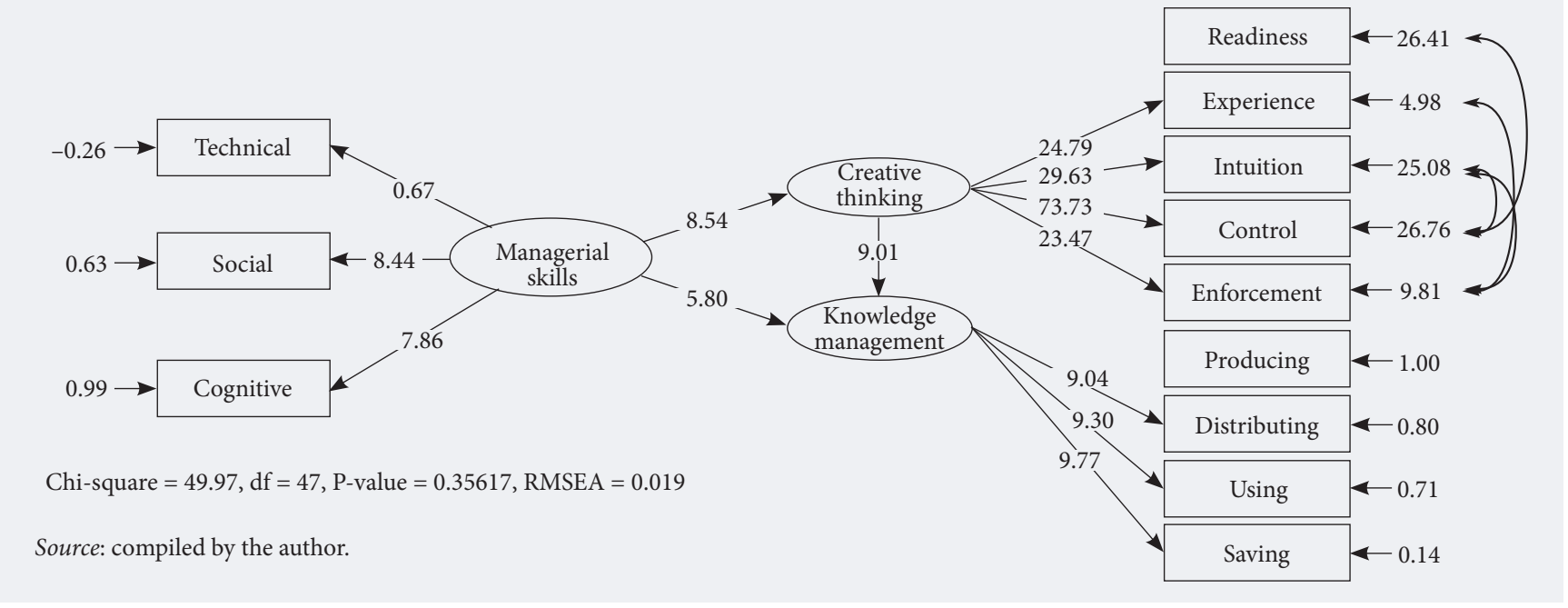

organizations pay attention to this fact, and that managers possess some skills to employ knowledge management and the advantages of those processes by constantly encouraging the development of those skills at their organizations. Also, the senior directors of organizations must provide an essential and appropriate infrastructure for developing managers' skills by holding training courses and making the basic arrangements. Furthermore, they should try to remove barriers impeding the implementation of knowledge management processes at their schools and organizations.

\section{References}

Afshari M., Honary H., Ghafori F. (2013) Baresi Maharathaye Segane Modiriati (Edraki, Ensani, Fani) Modiran Tarbiat Badani Daneshgahay Sarasar Keshvar [Investigating triple management skills (technical, human, and perceptual) of mangers of physical education departments in universities]. Faslname Modiriate Varzeshi, vol. 3, no 10, pp. $105-115$ (in Persian).

Alagheband A. (2005) Modiriat Omumi [Public management], Tehran: Ravan Publications (in Persian).

Ameri M., Areze K. (2014) Baresi Rabete Modiriat Danesh ba Maharathaye Ertebati Modiran Sazeman Tarbiat Badani Iran [Investigating the relationship between knowledge managment and communication skills of Physical Education Organization managers in Iran]. Faslname Motaleat Modiriat Varzesh, vol. 5, no 13, pp. 12-17 (in Persian).

Buzan T. (2003) The Mind Map Book, London: BBC Active.

Che Rusuli M.S., Tasmin R., Takala J., Hashim N., Phusavat Walsh J., Yaacob R.A. (2013) Relationship between knowledge management practices and library users'satisfaction: A preliminary result of Malaysian university libraries. Paper presented at the International Conference on Technology, Innovation, and Industrial Management, Phuket, Thailand, 29-31 May 2013. DOI: 10.1007/978-94-007-7287-8 12.

Cochran W.G. (1977) Sampling techniques (3rd ed.), New York: John Wiley \& Sons.

El Sabaa S. (2011) The skills and career path of an effective project manager. International Journal Promanage, vol. 11, no 22, pp. 23-28.

Farahi M. (2014) Baresi Ertebat bein Maharateha ba Naghsh have Modiriati Aezaye Heiat Elmi Moavenat Amozesh Naja: Bar Asas Nazariye do Ameli Herzberg [Investigating the relationship between skills and management roles of faculty members of NAJA Educational Assistant based on Herzberg's two-variable theory]. Faslname Motaleat Modiriat Entezami, vol. 7, no 27, pp. 27-39 (in Persian).

French V., Bill S. (2013) Management of evolution in organization (translated by M. Alvani, H. Danaiefard), Tehran: Nasr publications (in Persian).

Ghazizade S., Atayee S. (2013) Modiriat Danesh, Amele Asarbakhshi Sazemanha [Knowledge management, effective factor in productivity of organizations]. Majale Elmi Pajohesh Daneshgah Emam Hossein (A. S.), vol. 4, no 21, pp. 37-58 (in Persian)

Hafez K., Alghatas F. (2007) Knowledge Management in a Virtual Community of Practice using Discourse Analysis. Journal of Knowledge Management, vol. 5, no 1, pp. $29-42$.

Hara S., Stranberg K. (2009) Check thinking styles of creative people. International Journal of Creative Thinking, vol. 23, no 7, pp. 81-88.

Katz R.L. (1974) Skills of an Effective Administrator. Harvard Business Review, September issue. Available at: https:// hbr.org/1974/09/skills-of-an-effective-administrator, accessed 15.12.2016.

Khodayari R. (2006) Baresi Rabete Tafakor Khalaghe Modiran va Tavanayee Anha Dar Hale Barkhi Moshkelat Dabirestanhaye Pesarane [Investigating the relationship between mangers' creative thinking and their ability to solve some problems of male high schools]. Faslname Modiriat, vol. 3, no 6, pp. 40-52 (in Persian).

MirKamali M.S. (1996) Tafakor Khalagh va Barvari an dar Sazemanhaye Amozeshi [Creative thinking and its productivity in Educational organization]. Faslname Talim va Tarbiat, vol. 47, pp. 22-30 (in Persian).

Nonaka I., Takeuchi H. (1995) The knowledge-creating company: How Japanese companies create the dynamics of innovation, New York: Oxford University Press.

Rezaiean A. (2003) Mabani Sazeman va Modiriat [Bases of organization and management], Tehran: Samt Publications (in Persian).

Robbins A. (2010) Organizational Behavior, vol. 1 (translated by M. Zare), Tehran: Nasr Publications (in Persian).

Shaker A.Z. (2007) Knowledge sharing and technological capabilities: The Moderating role of family involvement. International Journal of Business and Management, vol. 15, no 11, pp. 102-118.

Smith A.D. (2004) Knowledge management strategies: A multi-case study. Journal of Knowledge Management, vol. 8, no 3, pp. 6-16. Available at: https://doi.org/10.1108/13673270410541006, accessed 31.03.2017.

Torrance E.P. (1980) Growing Up Creatively Gifted: The 22-Year Longitudinal Study. The Creative Child and Adult Quarterly, vol. 3, pp. 148-158.

Wiig K.M. (2000) Application of Knowledge Management in Public Administration. Paper prepared for Public Administrators of the City of Taipei, Taiwan, ROC May, 2000. Available at: http://citeseerx.ist.psu.edu/viewdoc/do wnload?doi=10.1.1.202.284\&rep=rep1\&type=pdf, accessed 24.02.2017. 


\title{
Human Resource Management at Russian Companies - Leaders of the Global Economy
}

\author{
Elena Zavyalova \\ Professor, zavyalova@gsom.pu.ru \\ Dmitry Kucherov \\ Senior Lecturer, kucherov@gsom.pu.ru \\ Victoria Tsybova \\ Senior Lecturer, tsybova@gsom.pu.ru
}

Graduate School of Management at the St. Petersburg State University 109 Sankt-Peterburgskoe sh., St. Petersburg 198515, Russian Federation

\begin{abstract}
$\mathrm{O}$ ne of the main sources of competitiveness on the modern economy are the intangible assets of companies. In the structure of the intellectual capital assigned to human resources and human capital, the knowledge, skills, creativity, and employees' motivation play a special role. The quality of human resources affects the value of the company and human resource management practices, which in turn affect the quality of its human resources.

The article focuses on a resource-based view of the firm and human capital theory as fundamental perspectives, linking human resources to achieving a sustainable competitive advantage for the company.

The empirical study tested the assumption that Russian companies, the leaders on the world economy, implement management strategies and practices that facilitate the efficient use of human resources in order to achieve one's main goals, which distinguishes them from companies that have not reached a level of international competitiveness.

The main tool for research is a questionnaire - the standard "Investors in People" survey - that is used to assess the effectiveness of policies and practices of the management and development of human resources at companies. The survey involved representatives in executive management positions at 41 public Russian companies; 14 of the surveyed companies were included on the Forbes Global 2000 (2014) and possessed the traits of competitiveness.

The results showed that at companies with competitive features, there is a pronounced tendency for the greater involvement of employees in the process of goal-setting and decision-making. There were also some differences in the practice of management personnel between companies with and without indicators of competitiveness. In general, the assumption that Russian companies have reached a level of leadership at a global level, using more effective policies and management practices, and the development of human resources to achieve its goals, as a result of the study, is confirmed.
\end{abstract}

\section{Keywords:}

human capital; human resource development; strategic management; international competitiveness;

Forbes Global 2000 
S trengthening national competitiveness, which is a priority of Russia's socioeconomic development, involves exploiting the country's market advantages and promoting the new knowledge-based economy. Accordingly, factors affecting competitiveness at Russian companies operating on international markets has become particularly relevant, and these vary depending on the approach chosen for their analysis. Researchers agree that at the macro-level, competitiveness is hindered by the fragmentation of the Russian economy, the technological gap, obsolete equipment, and insufficient attention of the government toward the production sectors [Kleiner, 2012; Khudorkomoff, 2005]. A no less important factor affecting competitive success, for the country as a whole and for individual companies alike, is human capital.

The multifaceted nature of the above issue requires adopting an integrated approach for dealing with it and the application of advanced strategic management theories, first of all, the concepts of a resourcebased view and human capital [Ignatova, Vasilyev, 2013]. Access to external and internal resources is a key element of companies' competitiveness, but occasionally it turns out not to be enough. The management's ability to make adequate use of available opportunities becomes no less important [Medvedev, 2012]. Conventional management techniques built upon resource-based approaches do not allow for fully realizing human capital's potential. Most companies make use of no more than $20 \%$ of it [Aksyonova, 2008; Zaitseva, 2014], while the lion's share of knowledge and skills accumulated by their employees remain neglected due to inadequate management.

Our main hypothesis for studying the application of human resources by internationally competitive Russian companies amounted to identifying the approaches they use and those employed by less successful international market players. Detecting specific differences between them was the goal of this study. The following objectives were pursued in order to accomplish it:

- An analysis of the economic concepts of business competitiveness using the resource-based approach and human capital theory;

- An analysis of human resources management strategies and practices employed by internationally competitive companies;

- To propose a valid research methodology;

- An analysis of the empirical data on human resources management by globally competitive companies. From a practical point of view, the results of the study could help optimize the operations of companies striving to become globally competitive.

\section{The Resource-Based Concept and Human Capital Theory in Present-Day Corporate Management Practices}

Contemporary strategic management theory is strongly influenced by the resource-based concept of firms' operations [Prahalad, Hamel, 1994; Teece, Rumelt, 1994; Collis, Montgomery, 1997; Grant, 2002]. According to Valery Katkalo, "over the last 15 years the resource-based view became the dominating paradigm of strategic management theory" [Katkalo, 2006, p. 321]. Like other strategic management concepts, the resource-based approach is applied to identify

"...the sources of, and mechanisms for, creating firms' sustainable competitive advantages, which allow them to gain economic benefits (rent) unavailable to rivals" [Katkalo, 2006, p. 52].

Alternative concepts propose an analysis of the links between the strategy and relevant organizational structures [Chandler, 1962], their hierarchies and implementation mechanisms, taking into account factors of the external and internal environment (the "design school" [Andrews, 1971; Christensen et al., 1987]); strategic, administrative, and operational planning and action (the "planning school" [Ansoff, 1965]); and identifying industries with potentially high profit margins (the "positioning school" [Porter, 1980]).

The resource-based concept was proposed to counter the theory of industrial organizations [Porter, 1980; Porter, 1985], which stressed the role of external factors in strategic planning for intra-industry competition. This approach [Barney, 1991; Wernerfelt, 1984] is based upon seeing companies as sets of unique resources and potential, which are reflected in their strategies and serve as the primary sources of their profits. Competitiveness in specific market segments is linked with the thorough stock-taking of all available internal resources, an assessment of the company's potential, and an adoption of relevant strategies.

Proponents of the resource-based concept assign particular importance to human capital and other resources. Jay Barney [Barney, 1991] links competitive advantages with the acquisition and efficient application of unique resources unavailable to one's competitors. He divides such resources into three groups: physical, organizational, and human capital. The latter is comprised of education, professional experience, attitude, intelligence, relationships, and one's understanding of operational processes by management and staff. Thus, in order to create a competitive edge, human resources must have the following four properties [Barney, 1991]:

- value, which arises from matching candidates' individual competencies to corporate requirements, since each staff member makes a unique contribution to a company's success;

- rarity, which is linked with staff members' cognitive abilities and the shortage of gifted employees;

- uniqueness, due to the competition's inability to identify the exact source of competitive advantages in the mass of human resources and reproduce the conditions for their emergence; and values and standards that affect the team's performance; 
- impossibility of replacing human resources with technology in the long term, since the former can be used to produce various kinds of goods and services.

The creators of the resource-based concept [Prahalad, Hamel, 1994] note that companies that accumulate and make use of human capital capable of learning faster than a competitor's and more efficiently use skills and knowledge that meet the needs of the business hold the competitive edge. Getting such results requires effort by the both sides, i.e., highly motivated employees who are willing to learn and an employer who creates a favorable environment for learning and sharing knowledge and experience. Though nobody questions the role of human resources in the scope of the resource-based concept, certain important issues still remain unexplained. For example, how does corporate strategy affect human resource management, and how does the latter affect company performance? What kind of employee behavior would help the company acquire long-term competitive advantages?

Some of the resource-based concept proponents see human capital as a source of management costs. This view is based upon the economic efficiency logic, which implies that reduced (or maintained at the same level) costs result in increased profits. However, this approach is hardly applicable to the evolving socioeconomic environments and emerging management models.

Human capital theory as a specific economic analysis field emerged in the US in the middle of the $20^{\text {th }}$ century [Mincer, 1993; Schultz, 1971; Becker, 1994]. It remains one of the more influential approaches to studying employees' and employers' behavioral and decision-making patterns and mechanisms in the scope of the present-day labour relations. The human capital theory deals with the process of the qualitative development of human resources, i.e., knowledge, skills, and abilities every person possesses and uses for production or consumption purposes [Kapeliushnikov, 2006; Kapeliushnikov, Lukyanova 2010]. Acquiring high-quality human capital and investing in its development are seen as a source of strategic competitive advantages, on the macro-level (society) and micro-level (company) alike. In the latter case, the management system serves as the primary tool for the efficient application of human capital, including the various relevant strategies and practices.

Companies' human capital comprises the following:

- employees' abilities, which determine their professional achievements;

- the sum of their knowledge and skills;

- their motivation for using these abilities, knowledge, and skills in the interests of their employer.

Success in converting this capital into increased productivity and, accordingly, increased company revenues, largely depends on how favorable an environment the company manages to create. Thus, businesses' objectives should be to clearly define the requirements for employees; find, assess, and invest in the development and training of suitable candidates; meet their primary needs, and encourage them to accomplish relevant goals and increase productivity to the maximum possible extent.

Our study relies on the fundamental provisions of the resource-based approach concerning the role of human resources in achieving corporate goals. We have also used the principles of human capital theory regarding this resource's structure and the specific aspects of managing and developing it.

\section{Human Resource Management and Companies' Competitiveness}

An analysis of the sources reveals a correlation between companies' human resource management strategies and practices and their competitiveness. The latter is defined as the ability to successfully grow and compete in the long term [Kleiner, 2012]. In this case, human resource management is seen as a relevant functional area of corporate management. Despite researchers' great interest in the aforementioned relationship, the number of empirical studies in this field remains quite limited.

Authors of certain studies maintain that companies with access to more highly developed human resources more efficiently use their employees' knowledge, and can thus sustainably compete on global markets [Ling, Jaw, 2006, 2011]. International recruiting based on assessing candidates' competencies and experience positively affects such aspects of competitiveness as global marketing, innovation, and learning. Other authors note the important role human resource management plays in maintaining a competitive level of organizational competencies [Makadok, Walker, 2000; Minbaeva et al., 2003], given that most of the latter can only be acquired through lengthy training and personal development of employees. [Khandekar, Sharma, 2005] established a positive correlation between the development of human resources and company performance; firms' ability to attract and retain talent and develop employees' skills is a factor of their (international) success.

However, the actual mechanism of human resources creating a competitive edge for the company is still rather poorly understood [Grossman, 2000; LeBlanc et al., 2000; Dzinkowski, 2000; Ling, Jaw, 2011], the connection between these factors certainly has not been fully explained, either theoretically or practically.

\section{The Investors in People Standard as a Methodological Basis for Assessing Human Resource Management}

Despite significant advances in the field of human resources management by companies, no all-purpose tools for assessing it have yet been designed. We have used the Investors in People ${ }^{1}$ concept (which proposes a national standard for the quality of human resource management) as the methodological basis for our empirical study. Designed by the Confederation of British Industry and the British Trades Union 
Congress in the late 1980s - early 1990s, this standard was supposed to optimize corporate personnel management practices through ongoing improvement. In 1993, the organization of the same name was established, to promote the standard's development and application throughout the world.

Designing the Investors in People standard, the British government hoped to remain a "key player on the global economy" [King, 1995]. In 1994, the country ranked only the $23^{\text {rd }}$ among 44 economies in terms of the level of labour supply skills. According to Mary Chapman, in 1995, the executive director of Investors in People UK, the future of the UK's economy largely depended upon companies' ability to promote the development of their staff's potential and skills [ibidem]. A study conducted by the organization in the early 1990s concluded that, in order to achieve long-term competitiveness, British companies needed to quickly react to labour market changes, promote the development of their personnel's potential, put into place a vertically integrated structure to more efficiently use this potential, and encourage personnel to meet production targets [ibidem].

The Investors in People Standard was expected to improve companies' performance through the application of systemic strategies based on involving staff in decision-making and objective-setting. It was seen as a structural reform tool and a personnel development program at the same time [Ratcliffe, 1994], which led to its adoption by more than 30,000 British companies employing $27 \%$ of the total national workforce.

The standard comprises three sections which cover relevant aspects of companies' operations:

1. Application of efficient optimization strategies through personnel development;

2. Efficient optimization of company operations through personnel development;

3. Efficient investments in human resources.

Each of these areas includes ten specific criteria - indicators describing various business aspects:

1. The strategy for optimizing company operations is clear and understandable to the staff;

2. Staff training and development programs are specifically designed to support the accomplishment of company objectives;

3. Personnel management strategies are designed to extend the scope for employee development;

4. Requirements for the management's skills and knowledge are clear, and communicated to the staff;

5. Indicators for assessing the management's productivity are clearly defined;

6. Criteria and procedures for assessing employees' contribution to company operations are clearly defined and applied;

7. Employees are involved in decision-making to promote individual and group responsibility;

8. Efficient staff training and professional development programs are implemented;

9. Reasonable amounts are invested in staff training;

10. Personnel management mechanisms and procedures are systematically improved.

The above criteria conceptualize the following human capital theory principles: personnel is seen as a subject (as opposed to an object) of management; investments in personnel development are imperative; objective criteria are applied to assess returns on these investments; the company's personnel should be actively involved in accomplishing its objectives.

The 2004 study [Investors in People, 2004] confirmed that the adoption of the standard in question positively affects business development, specifically:

- It serves as a catalyst of change at companies;

- It allows for increasing revenues by optimizing personnel's performance;

- It positively affects company performance indicators (reduced labour turnover and improved availability; increased staff satisfaction and motivation; increased productivity and sales; reduced level of flawed products);

- It contributes to increasing returns on investments per employee;

- It helps employees understand company objectives and their role in accomplishing them.

The study revealed that implementing strategies and practices in line with the Investors in People standard positively affects both objective (productivity, return on investment, profit margins, etc.) and subjective (level of satisfaction, motivation) business performance indicators; however, the mechanism of this effect has not been explained. The authors of a major study "The impact of Investors in People on people management practices and firm performance" conducted by the Cranfield School of Management [Bourne et al, 2008] tried to accomplish this objective. According to the model they proposed, the correlation between this standard and companies' business performance indicators is due to the fact that firms implementing the Investors in People principles in their personnel management policies created a favorable organizational environment (which fosters cooperation and trust between employees, their involvement in common work) and promoted human capital flexibility (employees make more effort to develop professionally). All these changes are reflected in companies' non-financial indicators such as product and service quality, the ability to attract and retain key staff members, client satisfaction, etc. In turn, non-financial indicators indirectly contributed to a rise in financial ones.

The UK's experience of using the Investors in People standard as a management quality diagnostic tool proves its value in helping companies strengthen their competitiveness through human resources management. This conclusion justifies using the standard as a conceptual basis for assessing the specific features of human resource management and the development practices employed by companies, the subjects of this study. 


\section{Methods and Techniques of the Study}

A questionnaire comprising 39 questions was designed for the purposes of the study, broken down into seven sections in line with the Investors in People standard indicators:

1. Employees' attitude towards company objectives (11 questions).

2. Employees' participation in decision-making (3 questions)

3. Efficiency and validity of staff training programs (10 questions)

4. Overall management efficiency (6 questions)

5. Procedures for, and efficiency of, personnel assessment (4 questions)

6. Organization of personnel management (structure, hiring, motivation) (4 questions)

7. Employees' understanding of company values (1 question)

On the basis of the questionnaire's closed questions (i.e., those offering several answer options to choose from), a binary measuring scale was constructed. Some of the questions were supposed to be answered using the Likert scale [Allen, Seaman, 2007], others included the "Other" option with the opportunity to provide a detailed open answer. The questionnaire has been used in previous human resources management surveys of international [Ardichvili et al., 2012; Zavyalova et al., 2011] and Russian "best employer" companies [Kucherov, Zavyalova, 2012], and has proven its reliability.

The main sample is comprised of the largest Russian public companies on the 2014 Forbes Global 2000 list [Forbes, 2014]. This ranking has been published annually since 2003 and is based upon four corporate performance indicators: revenues, profits, assets (for the previous 12 months), and market capitalization. Subsidiaries' performance is also taken into account (those with over $50 \%$ of shares owned or controlled by the parent company). The Forbes methodology provides for making four separate lists of the 2,000 largest companies in terms of each of the above indicators. The entry thresholds in 2014 were $\$ 4.04$ billion for revenue, $\$ 250.9$ million for profits, $\$ 8.2$ billion for assets, and $\$ 4.86$ billion for capitalization. Companies included on at least one of these lists could compete for a place in the overall ranking and the final position was determined by the total score on all four lists.

In total, 28 Russian companies were included in the 2014 ranking. Given that annual turnover (or revenues) is the most objective of the Forbes criteria, the presence of Russian players in the ranking can be seen as a sign of their international competitiveness. Other important signs of the latter include companies' presence on more than one market and the possession of representative offices in other countries. The threshold barrier was operating in on least three foreign markets (including the CIS); 20 out of the 28 ranking participants met these criteria. They returned 14 completed questionnaires ( $70 \%$ response rate). The control group of public Russian companies not included in the 2014 Forbes Global 2000 ranking comprised 27 medium and large enterprises. The bulk of the literature on the Investors in People standard is devoted to companies of just that size because human resources management is formalized at such firms to a higher extent than elsewhere [Smith, Collins, 2007].

In total, 41 companies were covered by the study: 14 in the experimental group and 27 in the control group $^{2}$. Their industries are indicated in Table 1.

The respondents comprised top company executives and HR managers. Their positions are presented in Table 2.

Due to certain specific features of the study such as the size of the groups and the applied scales, a frequency analysis (the number of positive and negative answers given by members of the main and control groups) and a comparative analysis of sample shares were used as mathematical and statistical techniques to detect statistically significant differences (Z-statistics). They were supplemented with a qualitative analysis of answers to open questions.

\section{Results of the Empirical Study of Human Resource Management}

The summarized results of the empirical analysis, including the statistical validity of differences between the groups are presented in Table 3.

The most significant differences were noted for the following user groups (sections of the questionnaire):

1. Employees' attitude towards company objectives

2. Employees' participation in decision-making

3. Efficiency and validity of staff training programs

5. Procedures for, and the efficiency of, personnel assessment

6. Organization of personnel management (structure, hiring, motivation)

Companies in the main group show better results regarding the involvement of staff in accomplishing corporate objectives by delegating responsibilities and using various forms of communication. They also more frequently arrange on-the-job training at other organizations. As to staff training arrangements, the members of the main group are clearly focused on economic results (increasing revenues), while companies in the control group seem to be more concerned with improving overall performance indicators (market position, product and service quality). Companies in the first group use stricter criteria for assessing staff training efficiency (changes in behavior, satisfaction level), and more often use feedback assessment results (via the media).

Human resource management at companies included in the main group tends to be the responsibility of specialized structures supervised by top executives (deputy chairman of the board), which can be interpreted as evidence of this aspect being seen as strategically important. This is also confirmed by the answers to open questions (the "Other" option). 
Table 1. Main Activities of Companies in the Sample (\%)

\begin{tabular}{|l|c|c|}
\hline \multicolumn{1}{c|}{ Activity } & Main group & Control group \\
\hline Information technology & 14 & 4 \\
\hline Fuel and energy complex & 50 & 30 \\
\hline Production & 29 & 41 \\
\hline Finance and investment & 7 & 11 \\
\hline Trade & 7 & 4 \\
\hline Gold mining & 0 & 7 \\
\hline Construction & 0 & 4 \\
\hline Source: compiled by the authors. & & \\
\hline
\end{tabular}

Companies in the main group more often use external channels for hiring, they employ head hunters and maintain contacts with the relevant educational institutions. They use complex procedures to assess candidates, such as psychological and polygraph tests. Extra medical insurance and profit sharing are their preferred incentives for motivating employees.

Answering the open questions, respondents gave their personal opinions about their company and the procedures it employs. On the whole, they confirmed the trends identified through the frequency analysis (Table 4) regarding staff involvement in accomplishing corporate objectives and in strategic planning.

According to the respondents, at the main group companies, training is primarily organized to facilitate the accomplishment of strategic objectives, while in the control group, it typically serves more narrow, practical needs. The main group companies assess training programs on the basis of the level of employee involvement. Answers to the same open questions revealed that, unlike the control group companies, the main group firms apply various advanced motivation mechanisms such as corporate mortgage programs and personalized social benefits packages.

Open questions allowed us to obtain additional information about overall management efficiency. The largest number of answers were given for the questions about personality traits and the types of knowledge top managers needed to have. Notably, the respondents from companies in the main group cited much fewer qualities and knowledge areas compared with the control group. A possible explanation is a more positive attitude towards executive management in the first group. The survey revealed higher-level HR management structures in the main group, and specific policies aimed at involving line managers in this work. Answers by members of the control group companies generally demonstrated a high level of HR management and development, and a deep understanding of these activities' specific features.

\section{Conclusions}

The results of the empirical study provided a new perspective on the relationship between HR strategies and management practices on the one hand, and the international competitiveness of Russian companies on the other. The study was focused on analyzing competitive (the main group) and non-competitive (the control group) Russian companies operating on international markets. The resource-based strategic management concept [Barney, 1991; Wernerfelt, 1984; Prahalad, Hamel, 1994; Grant, 2002], and the human capital theory [Mincer, 1993; Schultz, 1971; Becker, 1994; Kapeliushnikov, 2006] provided a theoretical basis for the study. According to these approaches, companies' human resources are a source

Table 2. Positions of the Respondents (\%)

\begin{tabular}{|l|c|c|}
\hline \multicolumn{1}{|c|}{ Position } & Main group & Control group \\
\hline Deputy General Director & 7 & 11 \\
\hline HR Director & 7 & 15 \\
\hline Development Director & 7 & 0 \\
\hline Head of Personnel Department & 50 & 48 \\
\hline Deputy Head of Personnel Department & 7 & 8 \\
\hline Head of the Corporate University Department & 7 & 0 \\
\hline Head of the Recruitment and Personnel Development Department & 7 & 4 \\
\hline Head of the Training and Statistics Department & 7 & 0 \\
\hline Head of the PR Department & 0 & 8 \\
\hline Personnel and Special Projects Manager & 0 & 4 \\
\hline Deputy Development Director & 0 & 4 \\
\hline Source: compiled by the authors. & & \\
\hline
\end{tabular}




\section{Table 3. Summarised Results of Comparing the Main and Control Groups of the Study}

\begin{tabular}{|c|c|c|c|c|}
\hline Question & Answer & $\begin{array}{c}\text { Experimental } \\
\text { group }\end{array}$ & $\begin{array}{c}\text { Control } \\
\text { group }\end{array}$ & Z-statistics \\
\hline \multicolumn{5}{|c|}{ Company objectives } \\
\hline $\begin{array}{l}\text { How does management help its staff } \\
\text { accomplish company objectives? }\end{array}$ & Delegates responsibility & 71 & 52 & $1.65^{\star}(0.098)$ \\
\hline \multirow{4}{*}{$\begin{array}{l}\text { What is your personal contribution to } \\
\text { improving and optimizing company } \\
\text { operations? }\end{array}$} & Personal contact with management & 100 & 70 & $2.29^{\star \star}(0.022)$ \\
\hline & Speaking at meetings & 71 & 44 & $1.65^{\star}(0.098)$ \\
\hline & $\begin{array}{l}\text { Sending memos with information } \\
\text { or suggestions }\end{array}$ & 100 & 67 & $2.49^{\star \star}(0.013)$ \\
\hline & Through the corporate website & 57 & 22 & $2.19^{* *},(0.029)$ \\
\hline \multicolumn{5}{|c|}{ Decision-making } \\
\hline \multirow{2}{*}{$\begin{array}{l}\text { How does the management of your } \\
\text { company share information with staff? }\end{array}$} & Through newsletters and memos & 93 & 52 & $2.56^{\star *},(0.010)$ \\
\hline & Mailing lists & 79 & 48 & $2.09^{\star *}(0.037)$ \\
\hline \multicolumn{5}{|c|}{ Training } \\
\hline $\begin{array}{l}\text { What forms of staff training and } \\
\text { development does your company use? }\end{array}$ & $\begin{array}{l}\text { Organizes on-the-job training at } \\
\text { other organizations }\end{array}$ & 57 & 19 & $2.51^{\star \star}(0.012)$ \\
\hline $\begin{array}{l}\text { In your opinion, how important are the } \\
\text { following staff training and development } \\
\text { objectives for your company? }\end{array}$ & $\begin{array}{l}\text { They increase the company's overall } \\
\text { integrity }\end{array}$ & 86 & 100 & $-1.86^{*}(0.062)$ \\
\hline $\begin{array}{l}\text { In your opinion, how does staff training } \\
\text { and development contribute to improving } \\
\text { various aspects of your company } \\
\text { operations? }\end{array}$ & $\begin{array}{l}\text { They improve product and service } \\
\text { quality }\end{array}$ & 79 & 100 & $-2.32^{\star *}(0.021)$ \\
\hline $\begin{array}{l}\text { Which criteria does your company use } \\
\text { to assess the effect of staff training and } \\
\text { development upon company operations? }\end{array}$ & Increased revenues & 36 & 15 & $2.04^{\star \star}(0.042)$ \\
\hline \multirow{2}{*}{$\begin{array}{l}\text { How does your company assess } \\
\text { investments in training or the development } \\
\text { of individual staff members? }\end{array}$} & $\begin{array}{l}\text { Assesses changes in employees' } \\
\text { behavior }\end{array}$ & 36 & 22 & $1.62^{\star}(0.104)$ \\
\hline & $\begin{array}{l}\text { Assesses employees' satisfaction } \\
\text { with training results }\end{array}$ & 86 & 59 & $1.60^{\star}(0.109)$ \\
\hline \multicolumn{5}{|c|}{ Assessment } \\
\hline $\begin{array}{l}\text { How often does the management of your } \\
\text { company inform you about results of your } \\
\text { performance assessment? }\end{array}$ & $\begin{array}{l}\text { Regularly (after each job is } \\
\text { completed) + periodically (when a } \\
\text { part of the job is done) }\end{array}$ & 75 & 44 & $1.78^{\star}(0.076)$ \\
\hline $\begin{array}{l}\text { How does your company assess and } \\
\text { recognize employees individual } \\
\text { contribution to company operations? }\end{array}$ & Media coverage & 50 & 26 & $1.78^{\star}(0.075)$ \\
\hline \multicolumn{5}{|c|}{ Personnel management } \\
\hline \multirow{3}{*}{$\begin{array}{l}\text { Who is responsible for managing personnel } \\
\text { at your company? }\end{array}$} & HR department & 7 & 46 & $-2.43^{* *}(0.015)$ \\
\hline & Personnel manager & 0 & 31 & $-2.35^{\star *}(0.019)$ \\
\hline & Other & 36 & 4 & $2.45^{\star \star}(0.014)$ \\
\hline \multirow{3}{*}{$\begin{array}{l}\text { Which recruitment techniques does your } \\
\text { company use? }\end{array}$} & $\begin{array}{l}\text { Employment agencies/HR } \\
\text { consultants }\end{array}$ & 71 & 41 & $1.91^{\star}(0.057)$ \\
\hline & Head hunters/recruiters & 79 & 22 & $3.11^{\star \star}(0.002)$ \\
\hline & $\begin{array}{l}\text { Maintaining contacts with relevant } \\
\text { educational institutions }\end{array}$ & 93 & 70 & $1.67^{\star}(0.095)$ \\
\hline \multirow{2}{*}{$\begin{array}{l}\text { Which candidate selection techniques does } \\
\text { your company use? }\end{array}$} & Psychological tests & 50 & 19 & $2.10^{* *}(0.035)$ \\
\hline & Polygraph tests & 29 & 4 & $2.09^{\star \star}(0.037)$ \\
\hline \multirow{2}{*}{$\begin{array}{l}\text { Which employee motivation incentives } \\
\text { does your company employ? }\end{array}$} & Profit sharing & 21 & 0 & $2.27^{\star \star}(0.023)$ \\
\hline & Extra medical insurance & 86 & 56 & $1.93^{\star \star}(0.053)$ \\
\hline
\end{tabular}

of sustainable competitive advantages. We assumed that there was a connection between companies efficient use of human capital and their success in accomplishing key corporate objectives, in this case, becoming internationally competitive [Khandekar, Sharma, 2005; Makadok, Walker, 2000; Minbaeva et al., 2003], which was measured on the basis of the Forbes Global 2000 ranking. The results of the study on the whole confirmed this hypothesis.

The Investors in People standard was chosen as the methodological basis, which allowed us to establish that the HR policies of the companies included in the main group were predominantly based upon human 


\section{Table 4. Answers to open questions by company representatives}

\begin{tabular}{|c|c|c|}
\hline Question & Answers by experimental group & Answers by control group \\
\hline $\begin{array}{l}\text { How does management help } \\
\text { employees to accomplish } \\
\text { company objectives? }\end{array}$ & Promotes development, involves them in the process & - \\
\hline $\begin{array}{l}\text { How does management } \\
\text { involve you personally } \\
\text { in drafting long-term } \\
\text { development plans? }\end{array}$ & $\begin{array}{l}\text { All employees participate in drafting such plans in line } \\
\text { with their responsibilities; strategic goals and scenario } \\
\text { conditions are set during the planning exercise, } \\
\text { with each employee designing them through their } \\
\text { specific professional activities; then the materials are } \\
\text { consolidated at the level of departments and business } \\
\text { segments. }\end{array}$ & - \\
\hline $\begin{array}{l}\text { Which staff training and } \\
\text { development objectives do } \\
\text { you believe to be important to } \\
\text { your company? }\end{array}$ & $\begin{array}{l}\text { Corporate management } \\
\text { Increasing revenues } \\
\text { Extending markets } \\
\text { Maintaining status } \\
\text { Employees' cultural identity }\end{array}$ & $\begin{array}{l}\text { Increased production safety } \\
\text { Reduced accident and trauma rates } \\
\text { No downtime }\end{array}$ \\
\hline $\begin{array}{l}\text { Which criteria does your } \\
\text { company use to assess the } \\
\text { effect of staff training and } \\
\text { development upon company } \\
\text { operations? }\end{array}$ & $\begin{array}{l}\text { Employee satisfaction, training efficiency } \\
\text { Increased involvement }\end{array}$ & Reduced trauma rate \\
\hline $\begin{array}{l}\text { How does your company } \\
\text { assess investments in the } \\
\text { training and development of } \\
\text { individual staff members? }\end{array}$ & Increased involvement & - \\
\hline $\begin{array}{l}\text { What theoretical knowledge } \\
\text { do you believe your company } \\
\text { management needs to have } \\
\text { in order to efficiently lead, } \\
\text { manage, and promote the } \\
\text { development of employees? }\end{array}$ & $\begin{array}{l}\text { Knowledge of psychology, professional competence } \\
\text { Personal development training } \\
\text { Organizational management theory } \\
\text { Basic knowledge of management and management } \\
\text { psychology } \\
\text { Knowledge of processes } \\
\text { Ability to make non-standard decisions } \\
\text { Formal training in the business area they supervise } \\
\text { (e.g., oil production, machinery, and equipment for } \\
\text { chemical production); management training (project } \\
\text { management, personnel management) } \\
\text { Developing feedback } \\
\text { Knowledge of the latest advances in management } \\
\text { theory } \\
\text { Knowledge of the industry the company specializes in, } \\
\text { management, personality psychology }\end{array}$ & $\begin{array}{l}\text { Relevant higher education } \\
\text { Knowledge of company budget management } \\
\text { Knowledge of business management, basic } \\
\text { knowledge of economic theory and production } \\
\text { management } \\
\text { Setting of objectives, management theory, } \\
\text { feedback techniques } \\
\text { Knowledge in the main area of company's } \\
\text { activities, economics, and management } \\
\text { Energy industry economics } \\
\text { Economics, management, law } \\
\text { Knowledge of management and psychology } \\
\text { Management of team-building } \\
\text { Basic human resources management principles } \\
\text { Personal development training } \\
\text { Knowledge of chemical production }\end{array}$ \\
\hline $\begin{array}{l}\text { What practical skills do } \\
\text { you believe your company } \\
\text { management needs to have } \\
\text { in order to efficiently lead, } \\
\text { manage, and promote the } \\
\text { development of employees? }\end{array}$ & $\begin{array}{l}\text { Communication skills, maintaining business contacts } \\
\text { Knowledge of production processes and their various } \\
\text { stages } \\
\text { Team management skills, the ability to set adequate } \\
\text { objectives and oversee their accomplishment } \\
\text { Team building skills, ability to make decisions quickly } \\
\text { and clearly communicate them to staff } \\
\text { Personal efficiency } \\
\text { Technical knowledge } \\
\text { Practical production floor experience, management } \\
\text { experience, analytical skills, the ability to structure } \\
\text { large data arrays } \\
\text { Developmental feedback } \\
\text { Personnel development and motivation skills } \\
\text { Staff and technology management skills, ongoing self- } \\
\text { development }\end{array}$ & $\begin{array}{l}\text { Personal work experience up the career ladder, } \\
\text { from the production floor to director's desk } \\
\text { None } \\
\text { Ability to set adequate objectives and oversee } \\
\text { their accomplishment } \\
\text { Management theory, feedback techniques } \\
\text { Significant personal and management experience } \\
\text { Personnel management skills } \\
\text { Professional knowledge of the industry the } \\
\text { company specializes in } \\
\text { Constructive relationships; a common outlook on } \\
\text { how objectives should be accomplished } \\
\text { Ability to organize work, work experience } \\
\text { Basic management skills: objective setting, } \\
\text { monitoring, processing, connections } \\
\text { Work experience in management positions } \\
\text { Management skills }\end{array}$ \\
\hline
\end{tabular}

capital theory. Companies in the control group more often adhere to the resource-based management theory, according to which HR management tends to be object-oriented and serves operational objectives. The results of the study allow us to propose a number of recommendations for companies striving to become internationally competitive:

- HR management should be based on the principles of human capital theory;

- HR policies should be shaped at the highest administrative level, and integrated into the company's overall development strategy;

- Personnel should be involved in strategic goal-setting and corporate decision-making;

- Horizontal and vertical internal communication channels should be established, to receive knowledge from outside the company (e.g., via on-the-job training at other companies), and the free exchange of information and competencies between employees should be encouraged;

- Regular feedback on employees' performance at all levels should be given;

- High requirements should be set for employees' professional qualities, and personality traits should be introduced along with advanced techniques for their assessment;

- Professional labour market consultants should be hired to help with recruitment; 


\section{Table 4 (continued)}

\begin{tabular}{|c|c|c|}
\hline Question & Answers by experimental group & Answers by control group \\
\hline $\begin{array}{l}\text { What personality traits do } \\
\text { you believe your company } \\
\text { management needs to have } \\
\text { in order to efficiently lead, } \\
\text { manage, and promote the } \\
\text { development of employees? }\end{array}$ & $\begin{array}{l}\text { Management abilities, flexibility, persistence, analytical } \\
\text { abilities, high IQ, charisma } \\
\text { Wide range of interests, influence (persuasion), } \\
\text { responsibility } \\
\text { Honesty, openness, willingness to discuss difficult } \\
\text { issues and provide professional assistance to staff } \\
\text { Flexibility, commitment } \\
\text { Confidence, friendliness } \\
\text { Ability to make innovative, non-standard decisions } \\
\text { Professionalism, ability to learn, ability to work under } \\
\text { pressure, a focus on results, tolerance, a respectful } \\
\text { attitude toward people } \\
\text { Openness to new ideas, trust in people's potential, } \\
\text { curiosity, innovative outlook, personal involvement } \\
\text { Orientation towards clients, safe behavior, teamwork, } \\
\text { attention to detail }\end{array}$ & $\begin{array}{l}\text { High professionalism } \\
\text { Confidence, attention to personnel } \\
\text { Correctness, commitment } \\
\text { Charisma, respectful attitude toward colleagues, } \\
\text { optimism } \\
\text { Ambitiousness, courage } \\
\text { Professional competence, management abilities, } \\
\text { moral qualities, willpower, emotional traits } \\
\text { Ability to make difficult decisions, compromise, } \\
\text { be firm, think ahead } \\
\text { Tolerance, open-mindedness } \\
\text { High IQ, ability to work with people and establish } \\
\text { connections } \\
\text { Pronounced desire to accomplish common } \\
\text { objectives while achieving maximum self- } \\
\text { realization and personal growth } \\
\text { Persistence, ability to set realistic objectives } \\
\text { Consistency, interpersonal skills, systemic } \\
\text { thinking } \\
\text { Technical mindset, orderliness, responsibility, } \\
\text { teamworking skills } \\
\text { Active position in life } \\
\text { Firmness, loyalty, willingness to take care of staff } \\
\text { Focus on results, flexibility (ability to find } \\
\text { alternative solutions), organizational abilities }\end{array}$ \\
\hline $\begin{array}{l}\text { Who is responsible for } \\
\text { managing personnel at your } \\
\text { company? }\end{array}$ & $\begin{array}{l}\text { HR department, deputy general director for personnel } \\
\text { Personnel manager } \\
\text { Personnel department } \\
\text { An HR segment comprising HR and social policy } \\
\text { departments, supervised by a special vice-president; } \\
\text { HR services at subsidiaries (in proportion to their } \\
\text { size) } \\
\text { Deputy chairman of the board responsible for the area } \\
\text { We try to make all managers see personnel } \\
\text { management as one of their main responsibilities }\end{array}$ & $\begin{array}{l}\text { An appointed official for this specific task } \\
\text { HR and deputy chairmen responsible for the area }\end{array}$ \\
\hline $\begin{array}{l}\text { What employee motivation } \\
\text { incentives does your company } \\
\text { use? }\end{array}$ & $\begin{array}{l}\text { Corporate mortgage program, social benefits packages } \\
\text { for various employee groups }\end{array}$ & Extra longevity pay \\
\hline
\end{tabular}

- Procedures for an integrated assessment of the effect of staff training and development upon the company's performance should be as objective as possible, while subjective criteria such as trainees' satisfaction or their career development should also be considered;

- Various forms of long-term employment should be promoted, to facilitate the accomplishment of the company's strategic objectives (guaranteed profit sharing, etc.)

The methodology based on the Investors in People standard proved its value in selecting criteria with which to assess HR management practices at companies striving to become internationally competitive. It allows one to identify the techniques companies use to manage their human capital and invest in its development. This approach seems to be best suited for a knowledge-based economy.

As to limitations of the study, the small size of the main group can be mentioned; among other things it was due the small size of the total cohort of internationally competitive Russian companies, which might have affected the results of the mathematical and statistical analysis. The application of a more advanced methodology in subsequent empirical studies would help to overcome this limitation.

The study was funded in the scope of project № 16.23.1842.2015 "Supporting research by the faculty and staff of the St. Petersburg State University Graduate School of Management".

\section{References}

Aksenova O.A. (2008) Korporativnaya sistema generatsii znanii: formirovanie i metody upravleniya [Corporate Knowledge Generation System: Formation and Management Methods] (abstract of thesis), Saint Petersburg: Saint Petersburg State University (in Russian).

Allen I.E., Seaman C.A. (2007) Likert scales and data analyses. Quality Progress, vol. 40, no 7, pp. 64-65.

Andrews K.R. (1971) The Concept of Corporate Strategy, Homewood, IL: Irwin.

Ansoff H.I. (1965) Corporate Strategy, New York: McGraw-Hill.

Ardichvili A., Zavyalova E., Minina V. (2012) Human capital development: Comparative analysis of BRICs. European Journal of Training and Development, vol. 36, no 2, pp. 213-233.

Banutu-Gomez M.B., Banutu-Gomez S.M.T. (2007) Leadership and organizational change in a competitive environment. Business Renaissance Quarterly, vol. 2, no 2, pp. 69-90.

Barney J. (1991) Firm resources and sustained competitive advantage. Journal of Management, vol. 17, no 1, pp. 99-120. 
Becker G. (1994) Human Capital: A Theoretical and Empirical Analysis with Special Reference to Education, Chicago, IL: The University of Chicago Press.

Bourne M., Franco-Santos M., Pavlov A., Lucianetti L., Martinez V., Mura M. (2008) The impact of Investors in People on people management practices and firm performance, Cranfield: Cranfield University. Available at: http://www. iipturkiye.com/Content/Download/Cranfield-Impact-of-IIP-on-people-management.pdf, accessed 01.10.2015.

Chandler A.D. Jr. (1962) Strategy and Structure: Chapters in the History of the American Industrial Enterprise, Cambridge, MA: MIT Press.

Christensen C.R., Andrews K.R., Bower J.L., Hamermesh R.G., Porter M.E. (1987) Business Policy: Text and Cases (6th ed.), Homewood, IL: Irwin.

Collis D.J., Montgomery C.A. (1997) Corporate strategy: Resources and the scope of the firm, Chicago, IL: Irwin.

Dzinkowski R. (2000) The measurement and management of intellectual capital: An introduction. Management Accounting, vol. 78, no 2, pp. 32-36.

Forbes (2014) The world's biggest public companies. Available at: http://www.forbes.com/global2000/, accessed 14.10.2015.

Grant R. (2002) Contemporary strategy analysis: Concepts, techniques, applications, Malden, MA: Blackwell Business.

Grossman R.J. (2000) Measuring up: Appropriate metrics help HR prove its worth. HR Magazine, vol. 45, no 1, pp. 28-35.

Ignatova T.V., Vasilyev P.P. (2013) Povyshenie znachimosti teorii chelovecheskogo kapitala dlya upravleniya modernizatsiei rossiiskoi ekonomiki. Voprosy regulirovaniya ekonomiki [Journal of Economic Regulation], vol. 4, no 2, pp. 50-55 (in Russian).

Investors in People (2004) The benefits that Investors in People delivers. Available at: http://www.investorsinpeople. co.uk/Media/Pages/FastFacts.aspx, accessed 05.03.2015.

Kapelyushnikov R.I. (2006) Teoriya chelovecheskogo kapitala [The Theory of Human Capital]. Available at: http://www. libertarium.ru/10624, accessed 20.01.2016 (in Russian).

Kapelyushnikov R.I., Luk'yanova A.L. (2010) Transformatsiya chelovecheskogo kapitala v rossiiskom obshchestve [Transformation of human capital in Russian society], Moscow: Liberal Mission Foundation (in Russian).

Kat'kalo V.S. (2006) Evolyutsiya teorii strategicheskogo upravleniya [Evolution of the theory of strategic management], Saint Petersburg: Saint Petersburg State University (in Russian).

Khandekar A., Sharma A. (2005) Managing human resource capabilities for sustainable competitive advantage. Education + Training, vol. 47, no 8/9, pp. 628-639.

Khudorkomoff A. (2005) Konkurentosposobnost' rossiiskikh predpriyatii: mikroekonomicheskii podkhod [Competitiveness of Russian enterprises: microeconomic approach], Moscow: Russian-European Center for Economic Policy (in Russian).

King S. (1995) IIP, the skills gap and business performance. Management Development Review, vol. 8, no 5, pp. 25-28. Available at: https://doi.org/10.1108/09622519510771988, accessed 05.03.2015.

Kleiner G.B. (2012) Strategicheskaya konkurentosposobnost' rossiiskikh predpriyatii [Strategic competitiveness of Russian enterprises], Moscow: Free Economic Society; All-Russian Distance Financial and Economic Institute (in Russian).

Kucherov D., Zavyalova E. (2012) HRD practices and talent management in the companies with the employer brand. European Journal of Training and Development, vol. 36, no 1, pp. 86-104.

LeBlanc P.V., Rich J.T., Mulvey P.W. (2000) Improving the return on human capital: New metrics. Compensation \& Benefits Review, vol. 32, no 1, pp. 13-20.

Ling Y.H., Jaw B.S. (2006) The influence of international human capital on global initiatives and financial performance. International Journal of Human Resource Management, vol. 17, no 3, pp. 379-398.

Ling Y.H., Jaw B.S. (2011) Entrepreneurial leadership, human capital management, and global competitiveness. Journal of Chinese Human Resources Management, vol. 2, no 2, pp. 117-135.

Makadok R., Walker G. (2000) Identifying a distinctive competence: Forecasting ability in the money fund industry. Strategic Management Journal, vol. 8, no 21, pp. 853-864.

Medvedev A.G. (2012) Mezhdunarodnyi menedzhment: strategicheskie resheniya v mnogonatsional'nykh kompaniyakh [International management: strategic solutions in multinational companies], Saint Petersburg: Saint Petersburg State University (in Russian).

Minbaeva D., Pedersen T., Björkman I., Fey C.F., Park H.J. (2003) MNC knowledge transfer, subsidiary absorptive capacity, and HRM. Journal of International Business Studies, vol. 34, no 6, pp. 586-599.

Mincer J. (1993) Studies in Human Capital. Vol. 1: Investment in Human Capital and Personal Income Distribution, Cheltenham: Edward Elgar Publishing.

Porter M.E. (1980) Competitive strategy: Techniques for analyzing industries and competitors. New York: Free Press.

Porter M.E. (1985) Competitive advantage, New York: Free Press.

Prahalad C.K., Hamel G. (1994) Strategy as a field of study: Why search for a new paradigm? Strategic Management Journal, vol. 15 (summer special issue), pp. 5-16.

Ratcliffe P. (1994) Investing in managers. Management Development Review, vol. 7, no 5, pp.16-18. Available at: https:// doi.org/10.1108/09622519410771682, accessed 15.03.2016.

Schultz T.W. (1971) Investment in Human Capital: The Role of Education and of Research, New York: Free Press.

Smith A., Collins L. (2007) Between a rock and a hard place? A case study of the issues facing advisors in introducing IIP to SMEs. Journal of Small Business and Enterprise Development, vol. 14, no 4, pp. 568-581.

Teece D., Rumelt R. (1994) Understanding Corporate Coherence: Theory and Evidence. Journal of Economic Behavior and Organization, vol. 23, no 1, pp. 1-30.

Teece D.J. (2007) Explicating dynamic capabilities: The nature and microfoundations of sustainable enterprise performance. Strategic Management Journal, vol. 28, no 13, pp. 1319-1350.

Wernerfelt B. (1984) A resource-based view of the firm. Strategic Management Journal, vol. 5, no 2, pp. 171-180.

Zaitseva N.A. (2014) Chelovecheskii kapital v sisteme ekonomiki znanii [Human Capital in the System of the Economics of Knowledge]. Rossiiskie regiony: vzglyad v budushchee [Russian Regions: Looking into the Future] (electronic journal). Available at: http://futureruss.ru/new_economics/knowlege_economics/chelovecheskij-kapital-v-sistemeekonomiki-znanij.html, accessed 23.02.2016 (in Russian).

Zavyalova E., Ardichvili A., Kosheleva S. (2011) Human resource management and development practices in indigenous Russian companies and foreign MNCs: A comparative analysis. International Journal of Human Resources Development and Management, vol. 11, no 2-4, pp. 179-193. 


\section{SCIENCE}




\title{
The Approach of the Business Sector to Responsible Research and Innovation (RRI)
}

\author{
Annamaria Inzelt \\ Funding Director; and Honorary Professor, annamaria.inzelt@gmail.com
}

Laszlo Csonka

Executive Director, csonka.laszlo@penzugykutato.hu

IKU Innovation Research Centre, 24 Felhévizi u., HU-1023 Budapest, Hungary

\begin{abstract}
This paper focuses on the attitudes and approaches of businesses to responsible research and innovation (RRI), in that this emerging concept anticipates and assesses the various effects of research and innovation practice. The importance of this issue is highlighted by recent scandals in the automotive industry (and elsewhere). Much of our attention is devoted to corporate responsibility in the fields of research and innovation, an important value that goes beyond research. Our investigation was based on 27 case studies relating to companies from 14 European countries. The selection criteria went beyond those used most frequently in RRI studies, covering fields wider than the emerging techno-sciences. This explorative research makes it easier to comprehend the feasibility and importance of empirical research. This feasibility study is a first step in obtaining relevant knowledge about the progress of European companies moving towards responsible
\end{abstract}

Abstract

\section{Keywords:}

responsible research and innovation (RRI); corporate social responsibility (CSR); socioeconomic impact; sustainable development; ethical approach research and innovation. The cases investigated show the existing dimensions and mechanisms of RRI in creating and identifying the barriers hindering RRI. The analysis has shown that RRI is little known as a comprehensive concept at companies, but many address RRI topics under other concepts such as corporate social responsibility (CSR) or sustainability. Altogether, several features of RRI are well covered by large European companies, and the differences in business RRI activities and their scope may be explained by variations in the character of the entities concerned (size, ownership, industry). The novelty of this paper lies in its investigation into the business practices of RRI, not only as a whole, but by opening up 'the black box' to see which elements are more mature and which ones need further improvement. It also uniquely illustrates how different business characteristics influence the treatment of various RRI dimensions.
Citation: Inzelt A., Csonka L. (2017) The Approach of the Business Sector to Responsible Research and Innovation (RRI). Foresight and STI Governance, vol. 11, no 4, pp. 63-73. DOI: 10.17323/2500-2597.2017.4.63.73 
$\mathrm{I}$

$\mathrm{n}$ the age of the knowledge economy, the question of responsibility is at the heart of innovation. That societies must innovate is a fact, but at what cost to human life and the environment? This question is posed to various actors in innovation systems and occurs at different levels of society from the individual to global. A relevant example is the Volkswagen diesel scandal, which illustrates perfectly why responsible research and innovation (RRI) is a concern for the business sector. The company used a software code to mislead US testing procedures for nitrogen oxide simply to achieve more turnover and profit on the US market. ${ }^{1}$ The cars incorporated serious technical knowledge and had many innovative elements, but unresolved technical problems were disguised by software designed to deceive. So, the product as a whole epitomized irresponsible innovation.

This paper focuses on responsible research and innovation (RRI) by business organizations and, in the business sector, responsible innovation may be associated with all types of innovation: product, process, organizational, and marketing [OECD, Eurostat, 2005]. This paper focuses only on product and process innovations related to various techno-scientific areas and innovation, which is linked to research-based practices of technological development either for totally new or modified innovations. The companies not only bear the responsibility for the individual (their employees) and at the organizational level, but they also have a wider effect on national and international society through their linkages with other actors in the innovation system.

Responsibility is socially and politically relevant and influences the governance of the respective field [Grunwald, 2011]. The concepts of corporate responsibility (CR) [Goodpaster, 1983] and corporate social responsibility (CSR) [McWilliams, Siegel, 2001; et al.] are known and well embedded at large companies. A less well-known concept is the recently emerging term 'responsible research and innovation' (RRI) [Owen et al., 2012; et al.], which is an approach which anticipates and assesses future effects and societal expectations with regard to research and innovation, with the aim of fostering the design of inclusive and sustainable research and innovation. The meaning of responsibility in research is deeply rooted in the research community's knowledge and practice. However, knowledge of responsibility in innovation is much more limited, and we focus our attention on the company's responsibility regarding innovation, aiming to assert its importance in terms of values.

The literature has identified many possible dimensions or forms of RRI, and our research is based on previous studies and case studies, the better to gather knowledge on RRI in actual company practice and recognize different forms of RRI as identified elsewhere in the literature.

In our empirical analysis, we tried to deduce how the characteristics of individual companies influence their involvement in different RRI activities, by such questions as: How is the RRI concept understood and used by European companies? What are the main influencing factors for the involvement of companies in various RRI activities? Which features of RRI are important for companies (including both public and private activities)? Which factors are achieved by applying relevant mechanisms? What are the main burdening factors of RRI at a company level?

One of the novel contributions of the present empirical study originated in the composition of the sample. The selected companies cover a much broader field than that of emerging techno-sciences. The analysis shows clearly that RRI is an issue for companies in all sectors.

\section{Conceptual Background of RRI in a Rapidly Changing Environment}

The issue of responsible innovation (and responsible development) emerged relatively recently. In the last decades of the $20^{\text {th }}$ century, several radical innovations such as nanotechnology (for medicine and healthcare), information technology, biotechnology (genomics, genetically modified crops), synthetic biology, neurotechnology, robotics, and geoengineering led to the emergence of new sectors, called emerging technosciences, and, as a consequence, to increased responsibility.

The concept of RRI and its predecessors have a rich history in the literature (summarized by [Pavie et al., 2014]). This section does not examine this, although we highlight certain recent notions that are important to support this empirical analysis. Before discussing responsible innovation, however, we do make a little detour into the meaning of innovation in the $21^{\text {st }}$ century.

"Innovation is about change and this can take place along a spectrum of increasing novelty, from simple incremental improvements ... through to radical changes that are completely new to the world." [Bessant, 2013 , p. 1] In the $21^{\text {st }}$ century, radical innovations representing discontinuous events of technological change usually are the result of systematic $\mathrm{R} \& \mathrm{D}$, either in corporate laboratories or academic organizations and raise more issues of responsibility than do incremental innovations. (The latter are modifications to existing systems of products and processes, usually as a result of inventions and improvements suggested by engineers or users.) However, incremental innovations raise also many issues of responsibility, such as the adaptation of Chernobyl-type nuclear power stations. Innovation is a collective process fuelled by different kinds of knowledge and involves many actors within companies and from the outside world, as Rothwell described in his pioneering work [Rothwell, 1992]. Intra- and inter-organizational links are crucial and highly networked, such multi-actor environments are the emergent properties of the innovation system. Opening up innovation to employees, users, financiers, and others is important. So "innovation, whether technological or otherwise, is not simply a new set of techniques for doing things, but also ultimately new social practices and even institutions that transform the ways in which human beings interact with the world around them." [Grinbaum, Groves, 2013, p. 119].

\footnotetext{
The cars emit up to 40 times the allowable levels of air pollutants, which are called nitrogen oxides (NOx). This environmental pollution is dangerous since all emissions of nitrogen oxide are a major contributor to serious respiratory disease [Ghose, 2015].
} 
Nowadays innovation is a collective process that requires a collective approach to responsibility. Responsible innovation should be distinguished from mere innovation as not all innovations are good things [Bessant, 2013, van den Hoven, 2013]. Innovations may have negative consequences beyond positive benefits either in the introductory or a later stage (such as contergan or thalidomide, nuclear weapons, and the Fukushima nuclear power station).

The discussion on the societal and economic impact of science and innovation and the recognition of major challenges for mankind are also in the focus of RRI in governmental funding decisions on research and innovation. Responsibility has become a worldwide issue in many contexts, among them within developing countries. An important type of responsible innovation involving a societal dimension is 'frugal innovation, which emerged in developing countries. Frugal innovation creates value in socially desirable ways. This type of responsible innovation for people at the base of the pyramid is responding to some of the grand societal challenges to perform sustainable development [European Commission, 2016]. ${ }^{2}$

RRI is an emerging concept that influences companies' innovation activities. The term itself refers to an approach that is spreading rapidly throughout the European Union and has become an important element of the Horizon2020 (2014-2020 program period of EU). ${ }^{3}$ The working definition for EU projects, including ResAgora is:

"Responsible Research and Innovation is a transparent, interactive process by which societal actors and innovators become mutually responsive to each other with a view to the (ethical) acceptability, sustainability, and societal desirability of the innovation process and its marketable products (in order to allow a proper embedding of scientific and technological advances in our society)." [von Schomberg, 2013].

This concise definition expresses well that innovating responsibly entails a continuous commitment to four components: to be anticipatory, reflective, inclusively deliberative, and responsive [Owen et al., 2013, p. 29]. From a general point of view, however, the framing of responsible innovation has to move further and identify the dimensions of responsible innovation. For the purposes of empirical investigation, the four RRI segments were operationalized in the ResAgor $\mathrm{A}^{4}$ project by a dimension based on the previous experience of national experts. (Table 1)

Each dimension is an umbrella term. They cover many different activities and mechanisms. The types and characteristics of the studied companies influence how sophisticated the RRI dimensions are and which instruments are used to translate RRI into practice.

New or deepened responsibilities have broadened the circle of actors who have or may have a role in RRI. The agenda of responsibility differs by actor. The following actors should bear their responsibility in the research and innovation process: scientists, universities, innovators, businesses, policy-makers, and research funders. The state is responsible for defining the risks of technologies through product authorization procedures and product liability law, as well as ensuring market operators compliance [von Schomberg, 2013]. The responsibility of business organizations is to work to create socially desirable products.

Moreover, different traditional RRI cultures, their previous involvement in technological assessment, foresight exercises, science in society, and stakeholder communication may also influence the presence and

Table 1. Key RRI Segments and their Dimensions Operationalised for a Corporate Study

\begin{tabular}{|l|l|}
\hline \multicolumn{1}{|c|}{ Segments } & \multicolumn{1}{c|}{ Operationalized dimensions for investigation at the company level } \\
\hline Anticipatory & Societal Challenges \\
\hline Reflective & $\begin{array}{l}\text { - Sustainability } \\
\text { - Ethics } \\
\text { - Environment } \\
\text { - Health } \\
\text { - Gender equality } \\
\text { - Cultural heritage }\end{array}$ \\
\hline $\begin{array}{l}\text { Inclusively } \\
\text { deliberative }\end{array}$ & $\begin{array}{l}\text { Engagement: } \\
\text { - Societal actors (general public, civil societies, laypeople) } \\
\text { - Public engagement (scientists and business men) } \\
\text { - Orticipation of users (customers, consumers, patients), }\end{array}$ \\
\hline Responsive & $\begin{array}{l}\text { - Education, training, and investment in human resources } \\
\text { - Open access } \\
\text { - CSR }\end{array}$ \\
\hline Source: compiled by the authors.
\end{tabular}

\footnotetext{
${ }^{2}$ Frugal (also known as inclusive or grassroots) innovation is the process of reducing the complexity and cost of a good by removing non-essential features of, for example, a car or phone, or to develop specific goods, and this has the potential of addressing new markets or economically marginalized areas. This may also involve the re-engineering of traditional techniques by re-visiting the scientific base of technologies and know-how elaborated over the centuries. Frugal innovation is not revolutionary in terms of research and technology, but it has important novel value and is socially very useful. The investigation of frugal innovation goes beyond this study since none of the selected companies are involved in frugal innovation.

${ }^{3}$ The EC and the scientific community are approaching an internationally harmonized definition. See an overview in [Buzás, Lukovics, 2015].

${ }^{4}$ The full title of the project is «Responsible Research and Innovation in a Distributed Anticipatory Governance Frame. A Constructive Socio-Normative Approach». For more details see http://res-agora.eu/ (last accessed 21.04.2017).
} 
Table 2. The Realization of RRI Dimensions by Type of Companies

\begin{tabular}{|c|c|c|c|c|c|}
\hline & Total (nr.) & MNCs & International & Subsidiary & Domestic \\
\hline All respondents & 27 & 9 & 9 & 6 & 3 \\
\hline \multicolumn{6}{|c|}{ Frequent occurrence of dimensions (Nr. of firms) } \\
\hline Environment & 21 & 8 & 8 & 4 & 1 \\
\hline Engagement & 19 & 7 & 8 & 3 & 1 \\
\hline Ethics & 17 & 9 & 7 & 1 & 0 \\
\hline Sustainability & 17 & 7 & 7 & 3 & 0 \\
\hline CSR & 17 & 5 & 8 & 3 & 1 \\
\hline Gender equality & 15 & 5 & 6 & 3 & 1 \\
\hline Societal challenges and policy & 15 & 7 & 3 & 3 & 2 \\
\hline Education & 14 & 5 & 4 & 4 & 1 \\
\hline Health & 10 & 2 & 4 & 3 & 1 \\
\hline Open access & 7 & 3 & 3 & 1 & 0 \\
\hline Cultural heritage & 3 & 2 & 0 & 1 & 0 \\
\hline
\end{tabular}

Notes:

A multinational corporation (MNC) is usually a large corporation incorporated in one country and has worldwide activities that are centrally controlled by the parent companies.

An international company is incorporated in one country and has activities in at least two countries. It is geographically less dispersed than MNCs.

A subsidiary is a firm that is fully or partially owned by a MNC or an international company.

Source: Authors' compilation from case studies.

importance of various RRI dimensions. This paper, however, does not deal with these aspects [Grunwald, 2011; Mejlgaard, Bloch, 2012; Tsipouri, 2012].

\section{Sampling and Methodological Issues}

This explorative research has employed qualitative selection criteria for companies. The investigation should focus on large companies: either being large in terms of their turnover, profit, or important in their countries. Other criteria include that a company frequently introduces R\&D-based innovations, and that it is known to have established CSR (and RRI) policies. These selection criteria went beyond most RRI studies covering broader fields than emerging techno-sciences since they included companies from other sectors with traditional technologies in the investigation.

The ResAgorA project studied companies from 16 EU member states which differ by size, level of development, strength of institutional setting, the role of NGOs and activist groups, and traditions in any kind of responsibility.

The research sample covers 27 companies with full case studies from 14 countries. We have partial information on five companies from two countries not included in the analysis of the case studies. ${ }^{6}$ The sample is not representative, as the approach for selection was explorative-qualitative. Despite this, the set of investigated companies allows for formulating typologies of the companies from the perspective of the importance of RRI in the business sector. The importance of different dimensions of RRI in company practice is another important component of the empirical research. Except for three SMEs, all other companies are large, but of varying sizes (from 1,000 to 77,000 employees). By type, nine companies are multinational giants, and another nine are large international companies, of which three are still family-run (Table 2). Six companies are subsidiaries of MNCs and they are also large (except for one medium-sized firm) in statistical terms, but they are much smaller 'large' companies than those that belong to the previous groups. Three are domestic companies, one of which is large, two others are medium-sized (one was founded as a global company). These companies are also export-oriented, but they have no other operations in third countries.

The presence of multinationals and international companies in the sample is important as they are critical actors in research and innovation (RI) processes and in the RRI arena. Internationally operating companies have responsibilities not only in their home countries but also in other countries. Companies from the developed world are responsible also for developing nations. They influence the attitudes in many countries towards RRI through their activities and subsidiaries.

The vast majority of companies are $\mathrm{R} \& \mathrm{D}$-oriented and they introduce radical as well as gradual innovations, including adaptation-based examples. The companies in the sample have different characteristics by their field of R\&D and economic sector. ${ }^{7}$ At several companies, R\&D has focused on multidisciplinary research,

\footnotetext{
Participating countries were: Austria, Czech Republic, Denmark, Finland, France, Germany, Greece, Hungary, Iceland, Ireland, Italy, Lithuania, the Netherlands, Poland, Spain, and the UK.

${ }^{6}$ The case studies were prepared by national experts: Erich Griessler (AUT), Morten Velsing Nielsen (DEN), Gema Revuelta, Octavi Planelis \& Nuria Saladie (ESP), Mika Nieminen \& Veiko Ikonen (FIN), Elise Tancoigne \& Allison Loconto (FRA), Stephanie Daimer (GER), Lena Tsipouri (GRE), Annamaria Inzelt (HUN), Svandis Nina Jonsdottir \& Eva Dogg Diego Thorkelsdottir (ISL), Simone Arnaldi (ITA), Loreta Tauginiene \& Saule Maciukaite-Zviniene (LIT), Adri Albert de la Bruheze \& Gido Akse (NED), Jan Koslowski (POL) and Kalle Stahl Nielsen \& Dana Abi Ghanem (UK).

The selection of companies to be interviewed was hindered by the willingness of those approached. The sample contains companies from those pre-selected who were ready to respond and interested in the topics. Apart from positive experiences with
} 
and in others one or two fields may be identified from traditional to newly emerging fields such as biological, biomedical, chemistry, biochemical, physics, energy, ICT, and environmental science. The industrial branches of companies are also varied, such as pharmaceuticals, cosmetics, chemicals, building materials, machinery, ICT, electronics, construction equipment, the automotive industry, and the energy and fuel sector. These sectors differ in terms of environmental sensitivity or life sensitivity, which makes them either strictly regulated or only generally regulated sectors. These variations produce different responsible behaviors at the company level.

Methods of research were: Analyzing publicly available documents focusing on CSR and RRI activities to learn how companies regulate and treat CSR and RRI was the basic source of information, but face-to-face or telephone interviews with relevant personnel at companies formed the lion's share of the investigation. The preferred method of selection for interviews was to ask two different professionals at a high level (head of a department or senior employee) in the R\&D department and the division responsible for working with CSR or related issues. The case studies followed the same structure. The first section of case studies briefly described the business characteristics and RDI activities of the company, whilst the second identified how the companies addressed RRI issues, and which dimensions of RRI might be identified at the organization. The third section described the relationships between RRI and CSR, whereas the fourth section focused on mechanisms that actually achieve RRI. The fifth and final section summarized the perceived barriers to achieving RRI.

\section{RRI in the Making (Main Findings)}

One of the lessons of the case studies is that all companies are familiar with the old concepts of CR and CSR and they have many such mechanisms in their practice. The term RRI is much less frequently used. According to our empirical findings, the meaning of RRI is better known among companies involved in EU projects and/or active in regulated sectors. The bulk of the companies investigated is familiar with the term RRI and use it in practice. Others do not use the term but some RRI features may be identified in their practice, usually under the term CSR, with RRI not recognized independently, although the two are interconnected.

Some companies explained how they define RRI for themselves. For example:

- L'Oreal (France): Research and innovation responsibility is "developing efficient and affordable products that meet consumers' expectations; products that are the best in terms of quality, safety, environmental and social impact". According to them, responsible innovation is made of five pillars: (1) product safety, (2) environmental respect, (3) ethics, (4) fair procurement, and (5) adaptation to global diversity.

- DSM (The Netherlands) participates in the chemical industry's Responsible Care Program. "The responsible care program that explicitly mentions responsible innovation promotes the improvement of health, safety, environmental performance and communication with stakeholders in order to create sustainable innovation and supports products and (innovative) technologies that reduce energy use, minimize greenhouse gas emissions, and decreases the human footprint on our earth and its resources.'

The companies that have RRI awareness cover more dimensions of RRI than the others. However, a few dimensions of RRI may be observed at the companies who are not familiar with the term or simply do not use it. The implicit (or hidden) RRI activities may originate from limited knowledge about the subject of RRI, from limited attention to this kind of responsibility or just neglecting the term. Good examples of the latter are BASF and Siemens where RRI is an integral part of corporate thinking even if the term is not used. Another good example is Velux (Denmark), which uses the term corporate responsibility instead of CSR and RRI although the company is involved in RRI.

\section{The Presence of RRI Dimensions in Different Groups of Companies}

By their frequency, the RRI dimensions differ in the sample. The presence of the dimensions was summarized without distinction between those explicitly or implicitly expressed at the investigated companies.

The responsibility relating to the environment and engagement are present at the majority of companies (20 and 19 , respectively).

Many companies devote attention to RRI-related ethics as well as sustainability (17), societal challenges, societal policy (15), and education (14).

Health (9) and open access (7) are mentioned by a few companies inspired by sectoral features (healthrelated sectors and ICT, data producing companies). Some companies from other sectors discussed how controversial an issue open access is for them. The involvement of profit-based organizations in research (including universities) means that the process has become more secretive than ever. The business community alone cannot hope to achieve its full reward for inventions in patent-dominated industries if they allow open access instead of patenting. ${ }^{8}$ Some companies active in basic research mention that they would accept open access, but would prefer to publish in leading journals.

the bulk of busy RDI leaders and CSR/RRI professionals, there were some difficulties with (potential) respondents. Following a first approach, several companies refused to give an interview. Another problem occurred at the large companies where the second professional explicitly or implicitly (always postponed) refused the interview or delegated it to the PR department, which was hardly relevant for the study. Another problem emerged during the approval procedure. Some companies tried to seriously modify the information from the original interview using PR materials on project websites.

${ }^{8}$ Challenging this situation, Tesla has made their patents related to vehicle fuel cells available. Their step towards open access was followed later by Ford and Toyota for electric vehicles. 
Table 3. Differences in the Frequency of RRI Dimensions by Regulated and Non-Regulated Companies

\begin{tabular}{|l|r|r|r|}
\hline \multicolumn{1}{|c|}{ Rank of dimensions (for total) } & Total (nr.) & Regulated (\%) & Non-regulated (\%) \\
\hline All respondents & $\mathbf{2 7}$ & $\mathbf{1 1}$ & $\mathbf{1 6}$ \\
\hline Environment & 21 & 91 & 69 \\
\hline Engagement & 19 & 73 & 69 \\
\hline Ethics & 17 & 64 & 63 \\
\hline Sustainability & 17 & 55 & 69 \\
\hline CSR & 17 & 36 & 81 \\
\hline Gender equality & 15 & 55 & 56 \\
\hline Societal challenges and policy & 15 & 73 & 44 \\
\hline Education & 14 & 73 & 38 \\
\hline Health & 10 & 36 & 38 \\
\hline Open access & 7 & 27 & 25 \\
\hline Cultural heritage & 3 & 9 & \\
\hline Source: compiled by the authors. & & & \\
\hline
\end{tabular}

Almost all companies devote attention to gender equality as one of the universal equalities together with race and age, and this aspect is included in CSR or in other policies replacing CSR. It is almost entirely interpreted as the equal representation of men and women at all levels and not as considering gender in the innovation process. Some companies take into consideration whether or not women are pregnant and if they need special health protection during the research and innovation process.

Preserving and further developing the cultural heritage is infrequently mentioned by companies (3). These examples belong to CSR and they do not have RRI features.

The next paragraphs focus on the differences by groups of companies relating to the dimensions of RRI. The small sample allowed us to split the companies into two groups: regulated and unregulated industries (in short, we call the companies that belong to regulated sectors regulated companies). This criterion is important in the context of RRI.

The companies that belong to the regulated sector have a longer tradition of dealing with several dimensions of RRI and have more sophisticated mechanisms than those sectors neutral to civil society. All companies that belonged to the 'regulated' group were health-related and the majority belonged to the pharmaceutical industry, with other groups involved in chemical-, biological-, and biotechnology-based R\&D activities. One of the non-pharmaceutical companies was a large cosmetics company and another one was active in orthopedics.

Table 3 shows the frequency of RRI dimensions by these groups. When investigating the presence of the various dimensions of RRI at the companies, we took into account both explicit and implicit RRI activities whether or not companies use the RRI terminology.

All regulated companies (11), except one domestic example, mentioned environmental awareness, environment protection programs, and reducing the ecological footprint. Overall, engagement is also very frequently mentioned. A slightly larger proportion of regulated companies raised this than did nonregulated ones. Engagement covers a very broad range of actors (see Table 1).

Education is more frequently met at regulated than non-regulated companies. Education is again an umbrella type of dimension that covers many different activities. Some of the activities are closely interwoven with CSR. Few companies, whether they are regulated or non-regulated, arrange specific training for the staff on RRI-related matters with developing or adapting new training materials.

The difference in the RRI-related involvement in societal challenges and policy as well as in education is larger between regulated than non-regulated companies.

Societal challenges and societal policy are present either in companies' R\&D strategies or the companies' overall strategies. The most frequently mentioned major challenge is climate change and companies are searching for the relevant methods to diminish the ecological footprint of their products and processes. However, this dimension is not a strongly reflected issue since the documents mention it generally, however, no concrete actions and mechanisms are attached to them.

A higher share of non-regulated companies mentioned the importance of CSR than regulated firms, but we may assume that several non-regulated companies focused on general CSR and not on RRI-related CSR activities. Sustainability is more important for regulated than non-regulated companies. There are two other dimensions in which the RRI content is not very strong. Gender equality and cultural heritage belong more to CSR than RRI in the practice of companies.

In the different frequency of RRI dimensions, another typology of the companies can bring additional important information. If they are MNCs, internationalized, subsidiaries of earlier MNCs, or domestic companies, we could observe some different influences on their own decision-making power in RRI. ${ }^{9}$

This small research sample illustrates how important it is to investigate RRI dimensions by these different types of companies.

\footnotetext{
${ }^{9}$ The sample was too small to employ both important criteria simultaneously.
} 
There are differences among the companies in their CSR and RRI attitudes by their decision-making type: some subsidiaries are practically clones of their parent companies with limited potential to adjust to their home country, whilst others have some autonomy.

Ethics and sustainability are crucial for a larger number of MNCs and internationalized companies and less so for subsidiaries and domestic companies. Ethics are an important issue for all multinationals and were also mentioned frequently by other companies, but only by one of the six subsidiaries. The meaning of ethics is better developed (and understood) in the context of research than in that of innovation. The companies active in the regulated health sector are more familiar with this dimension than others (e.g., concerning testing on animal or on human subjects and the ethics of biomedical research). The ethical process for developing research and innovation programs and an ethical supply chain are among the issues. In any sectors where privacy is an issue, the companies' ethical code regulates this field. Some other ethical issues such as anti-corruption, anti-bribery, and child protection were mentioned, but these important ethical topics do not belong to RRI. As regards sustainability, it is possible that there are no major differences among MNCs, internationalized, and other companies. The companies with a more sophisticated organizational structure, a more detailed annual report, mentioned this issue, whilst others may have the same kinds of activity under different names. At some companies, the responsibility concerns people and the planet (and profit). Another difference may originate in a definitional problem. Some companies understand sustainability in a very complex way that goes beyond products and services. In their case, the internal processes should be sustainable in terms of using little energy and generating no environmental harm. Measures to achieve this are setting (external and internal) goals and targets, and monitoring and reporting performance. Beyond that, there is some overlap between the three dimensions: sustainability, environment, and health. Some companies have mentioned the same things in each dimension, while others have referred only to one, such as environmental sustainability, sustainable agriculture, and consumption.

Significant differences may be observed if we study different kinds of engagement. For example, policy engagement was mentioned only by some MNCs as a direct form. Multinational companies have their own roles to play in international fora. Some others highlighted policy engagement that can be achieved through associations. Public (civil society) engagement was more frequently mentioned but has different meanings. Some companies follow one-way communication, that is, by informing the public through lectures and meetings about research and innovation (R\&I). A more sophisticated form of engagement relies on twoway communication, debates and dialogues and not solely lectures, when scientists and businessmen listen to the public to understand the public perception of new technologies, this was, however, less frequent.

A few companies involve their suppliers and other stakeholders, which would be appropriate in an open innovation system. Several companies do not involve the public even if their activities will have major effects on them. The involvement of users (such as patients) is more common and sometimes such RRI activity is interwoven with marketing.

Education is important for more subsidiaries and domestic companies than for other types of firms. Education and training is thus a critical endeavor for responsible innovation, and not only for the current crop of future workers. Involvement in the development of teaching curricula to cover research and innovation ethics, environmental and health issues, and emerging technologies are also on the agenda of some of the large companies. The majority of companies feel responsible for future generations and thus science education is addressed. STEM (science, technology, engineering, and math) education is supported in various ways. (See more in the section on mechanisms).

CSR as a dimension of RRI was mentioned by many companies but there is no clear line between CSR and RRI. RRI is more frequently a part of CSR than vice-versa. In the frequency calculation of dimensions, we have included all companies where CSR covers RRI and we have negligible information on CSR as a dimension of RRI. In our opinion, the role of CSR is different from other factors. Not only conceptually, but also practically, it is doubtful whether it has a role to play as a component of RRI.

\section{Mechanisms Achieving RRI}

Different instruments and actions may be used to translate RRI into practice. Naturally, all regulated companies at least have regulation-related mechanisms and some of the companies from the non-regulated group have also introduced important RRI mechanisms. At several others, CSR mechanisms provide good tools for RRI.

Regulated pharmaceutical companies follow the principles of replacement, reduction, and refinement in the conduct of research involving animal testing to support the well-being of animals. Good laboratory practices, good clinical practices, and pharmacovigilance are among the priorities. The national permission and control system strengthens RRI practice (such as Richter (Hungary), L'Oreal (France), Ossur (Iceland), Pharmathen (Greece), DSM (The Netherlands) or 4Medicine Rek (Poland)).

The importance of RRI is expressed in the companies' documents, indices, employed mechanisms, and their institutional structure. The role of RRI-related institutions is to facilitate many RRI dimensions and coordinate the collaboration of units' responses to RRI challenges. There are different variations at the companies: a dedicated department, a group within a department, chief officer in the upper hierarchy, committees, or combinations of these solutions. Such organizations include the 'Resourcefulness Unit' at OMV, Austria; the Department of Ethics and Chief Sustainability Officer (with representatives from other departments) at L'Oréal, France: or the Committee of Ethics, Environment and Sustainable Department at Firm2, France ${ }^{10}$ ).

${ }^{10}$ This and some other sample companies were ready for interviews on the condition of anonymity. 
The mechanisms for achieving RRI are various. Some mechanisms are common among regulated companies: the institutionalization of responsibility issues at dedicated departments, as well as the use of soft laws, contract clauses, audits, and international indices and metrics to assess their progress. However, specific mechanisms are also developed within each company to tackle the specific challenges they face, for instance, safety at work versus affordable products.

A good sign of RRI awareness appears if companies measure their RRI performance and are happy to be listed in the relevant international rankings. The best RRI performing multinationals are listed on the Dow Jones Sustainability Index (such as Rolls Royce (UK) and Firm 2 (France)). Some others use these indices for monitoring their own RRI performance and approach the best performers (e.g., AstraZeneca, UK). Another group of companies measure more dimensions than international ratings do such as OMV Austria which has developed its own 'Key Performance Indicator Dashboard' (KPID) to measure sustainability using 19 indicators. L'Oréal of France developed green indicators (e.g., the level of renewable carbon in the final inputs; eco-toxicity, biodegradability, and water consumption) in order to assess their products and processes. The observable indicators for external as well as self-assessment and monitoring exist in the context of CSR and sustainability.

Many companies (all healthcare-related companies and some others) have created their own procedures, regulations, and directives related to several dimensions of RRI. A few companies use external assessment bodies for assessing their RRI activities (such as Astra Zeneca UK, Novamont Italy, and H\&S Italy).

The existing mechanisms vary by dimension and corporate activity. The influence of the European Union may be observed on the mechanisms. The EU's Code of Conduct, special and general liability regimes, standards, and evaluation systems for funding projects have not only external impacts on companies' RRI efforts but influence the internal mechanisms of the companies.

There are some mechanisms which work for several dimensions, and so it is worth investigating the mechanisms for sustainability, environment, and health. The aim of most companies is contributing to sustainability and positive impacts upon the environment (planet) and health (people). Hence, the majority of companies promote the improvement of health, safety, and environmental performance together. There are a few large companies which devote attention to assessing and evaluating the majority of their products and processes.

The systematic protection of the environment (to be sustainable) is supported by using ISO 1401 standards in product and process development. The certified Environment Management System portfolio (by ISO 9001) and monitoring process strengthens managerial capabilities.

Resource efficiency is also an important issue. Fuel producers and transportation manufacturers promote solutions for alternative fuels. The carbon disclosure project for diminishing carbon emissions is important for all sectors that are still large carbon emitters (carbon dioxide and other greenhouse gases).

Some companies are introducing smart manufacturing processes and recycling methods for processes and end-of-life products, which contribute to conserving resources (water, electricity, and minerals) and to diminishing any ecological footprint.

The key soft mechanisms for ethics are the various codes of conduct formulated by companies. The EU codes of conduct and liabilities either served as models or encouraged companies to design their own codes of conduct. The majority of companies have their own codes, but the importance of RRI issues differ between healthcare-related and other companies. The latter only touch upon RRI issues, whilst the healthcare-related devote significant attention to such issues as bioethics and animal ethics. Few companies have extended this practice to their partners. For example, L'Oréal (France) signed a Charter of Ethics ${ }^{11}$ with suppliers for sustainability commitments and AstraZeneca (UK) formed partnerships with companies that have ethical standards similar to their own.

As the previous section described, engagement relates to many different actors and the mechanisms have to take these into account.

Training seminars for employees provide a shared understanding of the workplace and its values, and a common understanding within companies is an important condition if employees are to be involved. The development of relevant structures facilitates the collaboration between units and responses from channelling units.

Public engagement is not very intensive at the studied companies and most mechanisms focus on creating an informed public. Companies are less interested in listening to public questions, comments, and opinions, even if some companies have experienced market problems due to their neglect of public opinion. A good example of public debate is Velux of Denmark which uses 'demonstration homes' to initiate a debate on the future of housing with both citizens and stakeholders.

General stakeholder engagement may be found at many companies, but RRI-related involvement is not very frequent. If it exists at all, it has different channels: networks and platforms. Four different examples from different techno-scientific areas illustrate this type of engagement.

- A platform at BASF Germany contributes to the nano dialogue to produce information about nanotechnology and exchanges questions and fears associated with it.

- A partnership with diverse stakeholders exists at Novamont, Italy: local authorities work to increase waste-sorting; farmers and their associations work to promote the sustainable production of raw biological materials for industrial processes; mass retailers and CSOs distribute sustainable consumer products and, more generally, a culture of sustainability.

\footnotetext{
${ }^{11} \mathrm{http}: / /$ www.loreal.com/group/governance/acting-ethically/code-of-ethics--a-guide-for-action (last accessed 07.10.2017).
} 
- The EU project's influence on stakeholders' engagement may be illustrated by Esteve, Spain. In the framework of an EU project, the company provided scientific, objective, and comprehensive information to patients on medical R\&D and maintained dialogues with patients. The company disseminates its findings among its partners in the development process (organizations in the Science Park, potential collaborators: pre-university and university students). Presumably the EU project was a good learning exercise and the company will continue this dissemination practice.

- Stakeholder communication may be organized not only at company level but at the sectoral level as well. The Netherlands' chemical industry has organized communication in cooperation with stakeholders in order to create sustainable innovations that reduce energy consumption, minimize greenhouse gas emissions, and decrease the human footprint on the Earth and its resources. Naturally companies are actors in this communication (such as DSM from our sample).

Since education and training cover different target groups, the mechanisms are also varied. Roughly one third of the companies organize annual training sessions on ethical issues and on inclusion for the staff. Mainly researchers and managers are involved. Some other companies have recognized the training as a task but have not yet started.

The responsibility for future generations of researchers and innovators has led to company involvement in STEM education. Many companies support, intellectually and financially, pupils and students of primary, secondary, and tertiary education institutions (e.g., NI Hungary and its parent company in all countries where they have activities). The companies support employees who participate in the teaching programs and other events at schools such as scientific seminars and the provision of educational organizations of all levels with up-to-date tools and equipment.

A few companies also have in-reach programs mainly for university students (from undergraduate to $\mathrm{PhDs}$ ). Students can participate in the company's projects, internships, and various placements for students to develop their skills and budding careers. The students who carry out research projects at their institutions have access to regular advice from the company (such as Richter, Hungary).

Some non-school forms of education are also common among the investigated companies: public lectures, organizing regional and national competitions involving the public in an emerging field of technology, sponsoring scientific festivals and science days are mentioned as measures.

Since several other RRI dimensions hardly exist in the sample, the related mechanisms are also scattered. It seems that open access has sectoral specificity: Esteve Spain (healthcare-related) as a member of an EU public-private consortium collects and publishes data and information through open access on the toxicity of their products during the development and production processes.

If a company devotes its attention to the cultural heritage, it regulates which kind of heritage it is ready to support, prescribes how to allocate the financial resources for that purpose and how to select candidates.

Gender equality is an important issue for the majority of the companies but only few of them have RRI-related specificities. A good RRI-related example is the responsibility for future generations of female professionals that exists at Rolls Royce UK. The company sponsors the UK Female Undergraduate of the Year, where the successful student is offered a paid internship at Rolls Royce, whereas in Germany, a company has sponsored Girls' Day, an event where female secondary school students are encouraged to envision and pursue careers in engineering. Another example relates to gender-specific health issues at Richter, Hungary, where pregnant women stop working in the laboratory and carry out office work.

Overarching mechanisms may be identified at companies serving several dimensions, such as awards. The companies may launch their own awards, for example, AstraZenecas (UK) Annual Global 3Rs (replacement, reduction, and refinement in animal testing) or participate in external award systems. They may compete for external RRI-related awards as well. Another form of encouragement is incentive-based solutions for sustainability, the environment, and safe and healthy working conditions (e.g., Richter, Hungary).

The companies that are using RRI concepts are employing various sophisticated RRI mechanisms. Meanwhile, others that do not have this specific concept employed in practice can be divided into two groups. 1) Companies which have the relevant mechanisms for RRI (3), and 2) companies which have none (5). The lack of RRI-related mechanisms at these five companies may originate in the wishful thinking of companies on one or more RRI dimensions mentioned in their documents only to avoid criticism.

\section{Barriers Impeding RRI}

Identifying the impeding factors of RRI at the company level was not an easy task. Before summarizing the responses on barriers, it must be noted that the interview question was open-ended. The respondents did not get a list of potential barriers to choose from. We were interested what they might come up with if they were thinking about this issue.

The companies that were more familiar with the term and have explicit RRI activities could describe the impeding factors more clearly. Of the 27 companies, 21 identified barrier factors, which are summarized in Table 4.

The first, most important factor was the companies' accumulated (or missing) capabilities (10 companies). This included a lack of competences in dealing with RRI; the existing negative mind-sets or lack of understanding (and information on) RRI; a lack of culture and/or structure to share knowledge (silo thinking, missing links between units); a lack of time for RRI; and a half-hearted move toward the open innovation system. Some other factors, such as a lack of tradition in dialogue and missing capabilities to take into account others' opinions also caused difficulties in arranging RRI in a participatory way. ${ }^{12}$ Even if

${ }^{12}$ This issue depends on a country's characteristics. EU member states are very different in their consensus-seeking traditions. 
Table 4. Main Groups of Barriers Identified by Companies

\begin{tabular}{|l|r|l|}
\hline \multicolumn{1}{|c|}{ Groups of barriers } & \multicolumn{1}{|c|}{$\begin{array}{l}\text { Number of } \\
\text { Companies }\end{array}$} & \multicolumn{1}{|c|}{ List of companies } \\
\hline Capabilities-related issues & 10 & $\begin{array}{l}\text { Kone (FI); LOOreal (FR); Firm\#1; (LT) Firm\#2 (LT); BASF (DE); Siemens (DE); } \\
\text { Medicine Rek (PL); H\&S (IT); Ossur (IS); deCODE (IS) }\end{array}$ \\
\hline Other business priorities & 8 & $\begin{array}{l}\text { OMV (AT), Rolls Royce (UK), Siemens, (DE), H\&S (IT), Firm\#2 (FR), KGHM } \\
\text { (PL), Telefonica (ES; Esteve (ES) }\end{array}$ \\
\hline $\begin{array}{l}\text { Cross-country law, regulatory, and } \\
\text { cultural differences }\end{array}$ & 7 & $\begin{array}{l}\text { Pharmaten \& Titan (EL), Richter (HU), AstraZeneca (UK), Nokia (FI), DSM } \\
\text { (NL); Philips (NL) }\end{array}$ \\
\hline Lack of education & 2 & Ossur (IS); deCODE (IS) \\
\hline Short-termism & 2 & Nokia (FI), Esteve (ES) \\
\hline Intellectual property regimes & 1 & Velux (DK) \\
\hline Source: compiled by the authors. & \multicolumn{2}{|l}{} \\
\hline
\end{tabular}

the company has learnt about the importance of stakeholders' participation in the research and innovation process, it lacks the expert know-how to organize stakeholder workshops. Public engagement in decisions on research and innovation's relevance, sustainability, and so on is burdened by limited scientific literacy and ill-informed lay people.

The second most frequent group of factors was the other business priorities that are much stronger than RRI (8 companies). Sales, marketing, or growth-based management models can hinder RRI. More sustainable products' costs may negatively affect the competitiveness of companies as potential customers often opt for cheaper products and leave other considerations aside. So, RRI effects cannot compete with core businesses and the expectations of high profits. Certainly, the economic risk of research and innovation may also burden RRI if this risk prevents the company from innovating. The latter phenomenon may be evaluated as the post-trauma of the economic crisis when a previously innovative company becomes reluctant to innovate. It is not easy to find the right balance between cost, competitiveness, profit and sustainability, environmental protection, and so on.

For global business operators, the different national regulatory regimes, cultural, and legal regional differences affect their consideration of the RRI dimensions. These companies lack the European governance system of RRI. The existing EU mechanisms that have a positive influence on RRI mechanisms in member states are not enough for them (4 companies).

Regulation means an accepted environment for the companies belonging to regulated sectors. However, the management of the regulations by authorities is an important impeding factor and includes the limited capabilities of regulators and/or permit-issuing actors (length of permit-issuing period). (3 companies)

Only a few companies raised the issue of a lack of education: ethics in science teaching has not existed in their countries. This kind of knowledge is crucial for a basic understanding of ethical dilemmas by the public and by the scientists of tomorrow.

One company raised the issue of the intellectual property regime as a barrier for collaboration (open innovation) that affects RRI. Companies may individually find pragmatic solutions that could satisfy all involved actors but adjusting the IP regime to the needs of $21^{\text {st }}$ century is an important task.

One of the companies brought to light short-termism as a burdening factor for RRI. Sustainability can be a long-term brand asset for the company, but it does not have short-term effects and this fact limits a manager's interest.

\section{Conclusions}

This exploratory research has been an exercise in stocktaking for the existing dimensions and mechanisms of RRI in the making, and it identifies the barriers hindering RRI.

The analysis has shown that the concept of RRI has slowly penetrated business practice. The understanding of the concept is influenced by sectoral characteristics and the national context. Even in the case of companies that are familiar with the term RRI and may identify some explicit activities, CSR hides (or covers) other RRI elements. Several dimensions are well covered by large companies. However, many companies address RRI topics under other concepts such as CSR, community development, diversity management, gender equality, and sustainability. In the latter cases, the companies could not identify any specific features of research- and innovation-related responsibility differing from corporate social responsibility. Differences in business RRI activities and the coverage of RRI dimensions may be explained by variations in the character of those businesses.

The sample size allowed us to draw only general lessons if we categorize the companies by their various characteristics. By the categories of size or ownership, we have a limited number of cases and each is influenced by sectoral differences (such as regulated and non-regulated). However, this attempt to group the companies provides some basis for suggesting larger scale empirical research including qualitative sampling. The novel value of this paper is that it not only investigates the implementation of RRI in business practice as one solid function, but it also reveals the relationship between the various dimensions of RRI within the companies. This approach allows us to identify certain dimensions of RRI that are well-known to the companies and which are properly addressed by various mechanisms. Another important value of the paper is that it calls attention to the differences in treating RRI stemming from the companies' characteristics. 
The study results in identifying which RRI dimensions are interesting for business organizations and could induce further studies, which will need to go into the details of how companies are performing within these dimensions.

Our exploratory research showed that some RRI topics are worth further investigation within a larger sample. New knowledge concerning barriers may contribute to improving RRI awareness and corporate practice at companies.

Practical lessons and recommendations: we do recommend that national research councils, EU research programs, and national and EU funding agencies of research and innovation facilitate the further increase of RRI awareness and activities with different tools. They need to broaden or introduce RRI criteria in project evaluation and funding decisions. This solution will prompt applicants to devote more attention to RRI. The recent application forms of the EU and of many member states contain questions on ethical issues, but other important elements of RRI are not among the evaluation criteria. The agencies can develop awards for RRI performance beyond sustainability and environmental issues. The same is true for monitoring RRI performance in terms of other dimensions.

Companies committed to both research and innovation, as well as the authorities, have tasks ahead of them to change the marginal role of RRI in strategic management thinking. Embedding RRI into the corporate culture may be supported with education and training as well as by efficient toolkits and RRI-focused funding criteria. All of these can help change the present situation.

These recommendations can be useful for the councils, businesses, and research organizations in Asian countries as well.

Within a few years, responsibility must lie at the heart of the innovation process at the majority of companies. Responsibility belongs to the day-to-day operating practices of all involved actors, as much as in the reflexive deliberation of decision-makers. These empirical findings provide good input for policymakers to further encourage enhanced responsibility in the business sector's research and innovation. For this purpose, the capacity for responsible innovation must be nurtured.

The paper is based on the empirical results collected by the work package 'RRI Trends' of the ResAgorA project (Responsible Research and Innovation in a Distributed Anticipatory Governance Frame. A Constructive Socio-Normative Approach). Funded by the EU's 7th Framework Program (GA nr. 321427). The authors would like to express their gratitude to Erich Griessler and Simone Arnaldi for their valuable comments during the first steps in the preparation of this research paper Furthermore, the authors are grateful for the work of the national correspondents who have prepared the 27 case studies as well as for the interviewees from the various companies who were ready to share their thoughts about the practices of RRI at their organizations.

\section{References}

Bessant J. (2013) Innovation in the Twenty-First Century. Responsible Innovation. Managing the responsible emergence of science and innovation in society (eds. R. Owen, J. Bessant, M. Heintz), Chichester: John Wiley \& Sons, pp. 1-25.

Buzás N., Lukovics M. (2015) A felelősségteljes innovációról (About responsible innovation) Közgazdasági Szemle, vol. LXII, no 4, pp. 438-456 (in Hungarian).

European Commission (2016) Horizon 2020. Work Programme 2016-2017. Topic 16: Science with and for Society, Brussels: European Commission.

Ghose T. (2015) Volkswagen Scandal: Why Is It So Hard to Make Clean Diesel Cars? Live Science, 24.09.2015. Available at: https://www.livescience.com/52284-volkswagen-scandal-clean-diesel-challenges.html, accessed 25.03.2017.

Grinbaum A., Groves C. (2013) What is "responsible" about "responsible innovation"? Responsible Innovation. Managing the responsible emergence of science and innovation in society (eds. R. Owen, J. Bessant, M. Heintz), Chichester: John Wiley \& Sons, pp. 119-142.

Grunwald A. (2011) Responsible Innovation: Bringing together Technology Assessment, Applied Ethics, and STS Research. Enterprise and Work Innovation Studies, vol. 7, pp. 9-31.

Mejlgaard N., Bloch C. (2012) Science in Society. Science and Public Policy, vol. 39, no 6, pp. 695-700. Available at: https://doi.org/10.1093/scipol/scs087, accessed 17.12.2016.

OECD, Eurostat (2005) Oslo Manual, Paris: OECD, Eurostat.

Owen R., Stilgoe J., Macnaghten P., Gorman M., Fisher E., Guston D. (2013) A Framework for Responsible Innovation. Responsible Innovation. Managing the responsible emergence of science and innovation in society (eds. R. Owen, J. Bessant, M. Heintz), Chichester: John Wiley \& Sons, pp. 27-50.

Pavie X., Scholten V., Carthy D. (2014) Responsible Innovation: From Concept to Practice, Singapore: World Scientific Publishing Company.

Rothwell R. (1992) Successful industrial innovation: Critical factors for the 1990s. R\&D Management, vol. 22, no 3, pp. 221-239.

Tsipouri L. (2012) Comparing innovation performance and science in society in the European member states. Science and Public Policy, vol. 39, no 6, pp. 732-740.

van den Hoven J. (2013) Value Sensitive Design and Responsible Innovation. Responsible Innovation. Managing the responsible emergence of science and innovation in society (eds. R. Owen, J. Bessant, M. Heintz), Chichester: John Wiley \& Sons, pp. 75-84.

von Schomberg R. (2013) A vision of responsible research and innovation. Responsible Innovation. Managing the responsible emergence of science and innovation in society (eds. R. Owen, J. Bessant, M. Heintz), Chichester: John Wiley \& Sons, pp. 51-74. 


\title{
Grant Research Support in Russia: What Can We Learn from the Russian Science Foundation's First Grant Competition?
}

\author{
Yuri Simachev ${ }^{\text {a }}$ \\ Director for Economic Policy, ysimachev@yandex.ru
}

Liudmila Zasimova ${ }^{\text {a }}$

Assistant Professor, Department of Applied Economics at the Faculty of Economic Sciences, lzasimova@hse.ru

\section{Timur Kurbanov a;b}

Post-Graduate Student; and Chief Specialist at the Evaluation Organisation Unit, kurbanovtim@gmail.com

\footnotetext{
a National Research University Higher School of Economics, 20, Myasnitskaya str., Moscow 101000, Russian Federation

${ }^{\mathrm{b}}$ Russian Science Foundation, 14, bld. 3, Moscow 109992, GSP-2, Russian Federation
}

\begin{abstract}
1 his paper studies the Russian Science Foundation's first grant competition, which was held in 2014 to select exploratory or basic research projects, in order to shed light on the following two questions: (1) who wins the grants, and (2) what factors are attributed to winning? The subsample of winners (when compared with the whole sample of applicants) seem to have higher proportions of projects submitted to the life sciences section, projects affiliated with the Russian Academy of Sciences (RAS) and projects from Moscow or the Moscow region. Besides, the heads of the winning projects had
\end{abstract}

Abstract better publication indicators. We find that the main factor attributed to winning in the grant competition is the evaluation score given by external experts, while controlling for other factors. Although experts' score is the most influential factor, the probability of receiving grant is strongly associated with others as well. Thus, projects affiliated with the RAS and with the head of the project holding a doctor's degree have some advantages, all other factors being equal. Furthermore, projects from the regions and, most importantly, with young project heads, are more likely to win.
Keywords:

grant;

basic science;

science policy;

research funding;

peer-review
Citation: Simachev Yu., Zasimova L., Kurbanov T. (2017) Grant Research Support in Russia: What Can We Learn from the Russian Science Foundation's First Grant Competition? Foresight and STI Governance, vol. 11, no 4, pp. 74-83. DOI: 10.17323/2500-2597.2017.4.74.83 
$\mathrm{O}$ ne of the commonly applied basic research funding mechanisms is a grant awarded by science foundations (or, occasionally, by agencies operating along the same principles), primarily public ones. Such structures tend to have access to significant resources. For example, in 2015, the US National Science Foundation's (NSF) budget amounted to about $\$ 7.3$ billion $^{1}$, while the Japan Society for the Promotion of Science (JSPS) allocated more than $\$ 2.6$ billion. ${ }^{2}$ Dozens of such foundations and agencies operate around the world, commanding quite impressive shares of the gross domestic expenditures on research and development (GERD) (Figure 1).

In Russia, the state Russian Foundation for Basic Research (RFBR) and Russian Foundation for Humanities (RFH) until recently remained the main grant awarding foundations. At the end of 2013, the Russian Science Foundation (RSF) ${ }^{3}$, established by a special law, ${ }^{4}$ was added to this list; it became the largest institution promoting fundamental and exploratory research in the country.

Our analysis focuses on the results of the first RSF grant competition for research projects ${ }^{5}$ held in 2014 . In terms of the lessons to be learned from the RSF's activities and the promotion of best practices, not only are the project selection results of particular importance, but also the possible (and unavoidable for any expert evaluation) biases towards (or against) certain groups of applicants, and the reasons for such biases. At the time of writing this paper, more than three years have passed since the first grant competition: the RSF has held more than 20 other competitions since. The requirements for applications, conditions for taking part in the competitions, and rules for selecting winners have been adjusted, sometimes quite radically, while the network of experts recruited by the foundation has been considerably expanded and altered. Chances are that certain partiality still remains in project selection, but the applied criteria were changed following the significant transformations at the organization of the overall academic environment and the structure of the projects.

\section{Figure 1. Leading International Science Foundations' Shares in GDP and GERD (USD)}

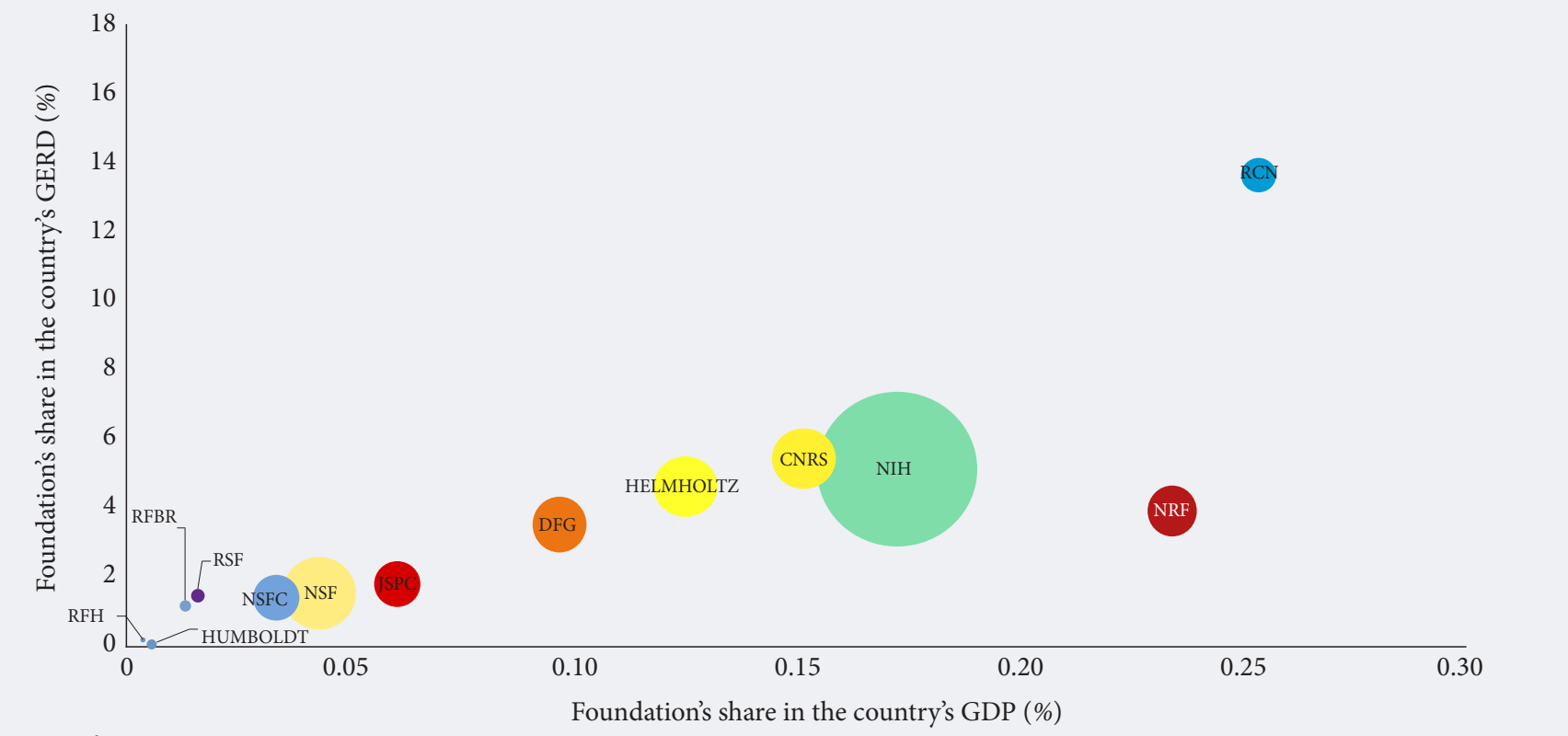

Legend:

NIH - National Institutes of Health, US;

NRF - National Research Foundation of Korea;

RCN - The Research Council of Norway;

JSPS - Japan Society for the Promotion of Science;

CNRS - Centre national de la recherche scientifique, France;

NSF - National Science Foundation, US;

NSFC - National Natural Science Foundation of China;

DFG - Deutsche Forschungsgemeinschaft, Germany;

Helmholtz - Helmholtz Association of German Research Centres, Germany;

Humboldt - Alexander von Humboldt Foundation, Germany;

RFBR - Russian Foundation for Basic Research;

RFH - Russian Foundation for Humanities;

RSF - Russian Science Foundation

Source: calculated by the authors based on data published by the World Bank (GDP), OECD (GERD), various foundations, and research organizations..

\footnotetext{
${ }^{1}$ Available at: http://www.nsf.gov/about/congress/114/highlights/cu15_0109.jsp, last accessed on 07.01.2016.

Available at: http://www.jsps.go.jp/english/aboutus/index4.html, last accessed on 07.01.2016.

${ }^{3}$ For more about the RSF and its activities, see its official website at: http://rnf.rf/ru/about, last accessed on 07.01.2016.

${ }^{4}$ Federal Law of 02.11.2013 № 291-FZ “On the Russian Science Foundation, and amendments to certain RF legislation”.

5 The official name is the "Competition for grants awarded in the framework of the Russian Science Foundation's priority activity area "Basic and exploratory research conducted by individual research teams"'.
} 
Table 1. Characteristics of the First RSF Grant Competiton by Field of Knowedge

\begin{tabular}{|l|c|c|c|c|c|c|}
\hline \hline Academic field & $\begin{array}{c}\text { Number of } \\
\text { accepted } \\
\text { applications }\end{array}$ & $\begin{array}{c}\text { Number of } \\
\text { supported } \\
\text { projects }\end{array}$ & $\begin{array}{c}\text { Share of } \\
\text { supported } \\
\text { projects (\%) }\end{array}$ & $\begin{array}{c}\text { Number } \\
\text { of expert } \\
\text { evaluations }\end{array}$ & $\begin{array}{c}\text { Number of expert } \\
\text { evaluations per } \\
\text { project (average) }\end{array}$ & $\begin{array}{c}\text { Number of } \\
\text { evaluations } \\
\text { per expert } \\
\text { (median) }\end{array}$ \\
\hline $\begin{array}{l}\text { Mathematics, } \\
\text { informatics, systems } \\
\text { science }\end{array}$ & 784 & 69 & 8.8 & 2302 & 2.94 & 4 \\
\hline Physics, space sciences & 1305 & 115 & 8.8 & 3850 & 2.95 & 5 \\
\hline $\begin{array}{l}\text { Chemistry, materials } \\
\text { sciences }\end{array}$ & 1328 & 122 & 9.2 & 3910 & 2.94 & 7 \\
\hline Biology, life sciences & 1085 & 150 & 13.8 & 3196 & 2.95 & 7 \\
\hline $\begin{array}{l}\text { Basic research in } \\
\text { medicine }\end{array}$ & 972 & 123 & 12.7 & 2842 & 2.92 & 7 \\
\hline Agricultural sciences & 120 & 17 & 14.2 & 343 & 2.86 & 2 \\
\hline Earth sciences & 703 & 70 & 10 & 2077 & 2.95 & 5 \\
\hline $\begin{array}{l}\text { Social sciences, } \\
\text { humanities }\end{array}$ & 3390 & 94 & 2.7 & 9772 & 2.88 & 14 \\
\hline Engineering sciences & 1528 & 115 & 7.5 & 4350 & 2.85 & 3 \\
\hline \multicolumn{2}{|l|}{ Total } & 875 & 7.8 & 32642 & 2.91 & 6 \\
\hline Source: calculated by the authors based on RFS data. & & & & \\
\hline
\end{tabular}

The establishment of the RSF has put an end to the competition between various approaches to funding fundamental research in Russia, including such traditional tools as government orders, thematic research plans, government programs and federal targeted programs based on contracts or budget subsidies, and even grants awarded by science foundations. The RSF has become the symbol of a resolute turn from targeted programs towards foundations, from public contracts to grants, thus changing the decision-making chains, the rules of the game, and the circle of major beneficiaries. Such a shift in the research policy prompted intense debates (not at all limited to academic circles) about the merits of the extended application of grant-based mechanisms, and whether it would create new problems to replace the old ones.

The first RSF competition was noteworthy because of its size: more than 12,000 applications were submitted by research teams specializing in all fields of knowledge, comprising more than 90,000 researchers altogether. When assessing the results of subsequent RSF competitions and discussing general approaches to supporting basic research in Russia, the participants of the relevant debates still tend to cite their personal impressions of the initial period of the foundation's operations.

A typical feature of Russian government policies (and science policy is no exception) are pendulum changes, when at each round of reforms, the faults of the previous one are absolutized while the changes not infrequently amount to swinging from one extreme to another, reproducing the problems in the process. The trade-off nature of certain decisions made during the early stages suggests the need to analyze the costs associated with the various ways of organizing science foundations and their operations. The value of retrospective analysis is that it provides the chance to avoid potential risks by learning from previous negative experiences. However, such an approach is not without its faults given that it does not imply a formalized or meaningful evaluation of the results and a comparison of them and the initial expert assessments of the submitted research project applications.

\section{Specific Features of the First RSF Competition}

The first competition for grants to fund research projects implemented by individual research teams in all academic fields was announced in February 2014 to provide grants for research in 2014-2016, with a possible extension by one or two years. Out of the 12,774 applications submitted by research teams from more than 1,200 organizations, 11,215 were selected for peer review (Table 1). Projects in the field of social sciences and humanities were in the obvious majority. The experts selected 875 research projects, though according to the organizers, the number of worthy applications was a good deal greater than the foundation could afford to fund [Khlunov, 2014].

The first of the two peer review stages involved assessing the applications and preparing conclusions about them. The coordinators of the evaluation council allocated project applications between the experts. The peer review procedure was unilaterally anonymous: researchers did not know who their reviewers were, while the latter could access information about the research teams and their members. Each application was assessed by three experts independently from one another other using several criteria. A project could receive a score between 0 and 120 points, which were awarded automatically when experts chose the relevant points of the expert evaluation. During the second stage, applications were evaluated by sections of the expert council on the basis of the preliminary expert opinions. To avoid any conflicts of interest, those projects for which members of the expert council had recommended funding had to be additionally approved by secret ballot following the second evaluation stage. The foundation's management stressed the need to take into account the researchers' opinions when final decisions were made [Khlunov, 2014]. 
Certain specific features of the first RSF competition should be noted, distinguishing it from tenders held by other Russian science foundations. By the beginning of 2014, two major research programs were completed: "Research and development in priority areas of the Russian S\&T complex in 2007-2013" and "Research and academic personnel for an innovative Russia in 2009-2013". After that, the funding of numerous research teams was discontinued, which prompted the management of the newly founded science foundation to organize a competition as quickly as possible. The law establishing the RSF was signed on November 2, 2013, the first competition to award grants to research teams was announced already on February 6, 2014, and its results were published on May 20 of the same year [RSF, 2015].

Researchers' great interest in the competition was due not only to a lack of funding, but also to the unique opportunity to obtain significant resources (up to 5 million rubles a year per team) with flexible spending arrangements and a moderate bureaucratic load. The same factors also explained the unusually stringent, in most of the researchers' opinion, principles of project selection: the share of awarded projects (success rate) in the total number of applications did not exceed $8 \%$. In the international context, such rate does not seem to be very unusual. For example, the relevant figure for France's Agence Nationale de la Recherche (ANR) is 8-12\% [ANR, 2015]. However, the debates that began after the RSF competition results were announced revealed that many researchers who had previously applied for the RFBR and RFH grants expected about a third of the projects to be awarded grants while they would be able to easily repeat their successful experience of participating in other competitions. Therefore, defeat was an unpleasant surprise for them, and the logic of selecting the best projects out of so many good ones declared by the RSF was not warmly received.

A major innovation introduced by the organizers was the "entry ticket" principle, the requirement for a minimum number of publications in Web of Science- (WoS) or Scopus-indexed journals by the team lead. At the first competition, this rule did not apply to all knowledge areas, an exception was made for the social sciences and humanities (their representatives have successfully argued these fields have distinct disciplinary and national features). As a result, scientists specializing in these areas found themselves in an irrationally favorable competitive position and submitted the largest number of applications, though less than $3 \%$ of them were approved (see Table 1). The burden on the experts in this group was also the highest: on average, each expert had to evaluate 14 applications in two months' time.

The peer review exercise in the scope of the first RSF competition was conducted on an exceptionally large scale and in a very short period of time. More than 2,500 experts participated in assessing the applications. The total number of prepared expert opinions exceeded 32,000, on average, there were three opinions per application. Given that at the time of its establishment the RFS lacked its own pool of experts, it recruited them from the RFBR and RFH as well as additional external experts specializing in certain subject areas [Klimenko, 2014].

\section{Research Hypotheses and Initial Data}

Grants are supposed to solve the problem of insufficient basic research funding by the private sector. The private sector is generally unable to provide such funding due to numerous reasons such as high risk, low or zero profit from the application of research results, and difficulties with the capitalization of fundamental discoveries [Nelson, 1959; Pavitt, 1991]. Without questioning the need to provide public support for research, our further deliberations are based on studies devoted to optimizing arrangements for the provision of basic research funding and, among other things, dealing with the issue of public investments pushing out private ones [Mowery, 1990] and finding the best ways to fund research through grants.

Studies on grant-based research funding revealed serious flaws in the relevant mechanisms employed by various countries. For example, applying for a grant not infrequently involves presenting already obtained research results, which means that only teams possessing a relevant portfolio have a chance to receive support [Lazeur, 1997]. Another common problem involves taking into account applicants' previous achievements, the so-called "Matthew effect" [Merton, 1968; Antonelli, Crespi, 2011]. In the case of awarding grants, it amounts to favorably treating research teams that at the time of application had a better reputation, more impressive results, better work conditions, etc. On the one hand, such policies adopted by science foundations encourage young researchers to more efficiently implement their projects due to the fact that their results would play a role in the future [Lazeur, 1997]. On the other, it means that the foundations' resources will be allocated in favor of more experienced applicants.

The relevance of the aforementioned barriers is confirmed by recent empirical research. For example, Arora and Gambardella [Arora, Gambardella, 2005] analyze, using NSF selection practices, how peer review and final grant allocation decisions are affected by such variables as the team leads' or leading researchers' characteristics (gender, year they received their $\mathrm{PhD}$ ); the name and type of applicants' organizations; the number of project participants; the number of publications during the previous five years, weighted by quality; and the reviewers' opinions, etc. The authors discovered a positive correlation between expert-assigned scores and the number of publications by applicants. Even if the projects proposed by researchers with impressive academic reputations turn out to have inferior formal parameters compared with competing applications, they still receive more favorable treatment when funding decisions are made. Meanwhile, young researchers only have a chance of receiving support if they are exceptionally successful (the authors call them "stars"). There is also a certain "positive discrimination," applicants from the regions tend to have a slight advantage over teams based in metropolitan areas.

An obvious answer to the challenges associated with the public funding of research projects is designing an optimal project selection mechanism. Along with the direct correlation between the number of applicants' publications and the awarding of grants [Arora, Gambardella, 2005; Jacob, Lefgren, 2011; Gush 
et al., 2015], there are also signs of an inverse relationship: researchers who were awarded grants tend to have much better chances to publish. For example, the experience of the New Zealand Marsden Fund [Gush et al., 2015] shows that publication activity increases even if the fund supports weak projects: the support is seen as evidence of the projects' quality and encourages scientific journals to publish papers by their participants.

An adequate project selection mechanism should provide a good balance between anonymous ("blind") peer review and space for "manual fine-tuning". The example of the NIH confirms that the higher the project's score assigned by experts at the first stage of selection was, the better results the supported team gets in terms of citation, patenting, publication, and contributing to the advancement of the relevant field of knowledge (keeping all other factors equal) [Li, Agha, 2015]. At the same time, the management of the program decided to make an exception for about $1 \%$ of the projects that did not score the minimum necessary number of points. Interestingly, the performance of these "manually selected" projects' teams measured in terms of their publication activity turned out to be comparable with those that received the highest scores at the project selection stage. Another study [Park et al., 2015] compared two mechanisms for the allocation of the NIH resources: regular and additional competitions. The latter's arrangements were the same as the main competition's, it was held for projects that had never been awarded grants but received high scores. The comparison did not reveal any significant differences between the performance of the teams awarded grants under these two tenders.

As we see, projects' prospects, and the validity of their peer review results, cannot be adequately estimated at the competitive selection stage. Therefore, studies of grant-based research funding concentrate on factors affecting project selection results. The main issues here are associated with the lack of transparency and predetermined results. Though peer review remains crucially important for the successful operation of science foundations, experts' decisions tend to be somewhat arbitrary and biased. Numerous studies reveal that such procedures are less than perfect, highlighting partiality regarding women, less prestigious organizations and subject areas, intellectual piracy, and barriers hindering publication [Smith, 2006; Benos et al., 2007]. Thus, designing an optimal project selection mechanism that would minimize the faults of the first and second kinds of selection has become a critical issue on the grant-based research funding agenda.

No large-scale empirical studies of research project selection have been conducted in Russia so far. International studies and domestic debates triggered by the results of the first RSF competition permit one to propose the following hypotheses on the factors affecting the selection of research projects to award grant funding:

Hypothesis 1: Research teams who, at the time of submitting an application, have a more impressive reputation, first of all due to the team leader's merits (such as his or her academic degree, number of publications, etc.) tend to have an advantage.

Hypothesis 2: The chances of receiving a grant depend not only on the scores awarded by individual experts, but also those given by the expert council as a whole, which in turn depends upon the characteristics of the research teams (their leaders and members) and applications (the requested amount of funding, the number of expected publications).

Hypothesis 3: If expert-assigned scores are equal, research teams from Moscow- and Moscow Regionbased academic institutes tend to have better chances of receiving support.

The empirical basis of the study is comprised of over 32,000 expert opinions on more than 11,000 applications. The analysis was based on data on awarded applications, applicant research teams (the number of publications by their leaders and participants, age, gender), and the projects (research area, expected results, etc.). A regression analysis (binary choice model) was used to assess the factors affecting the probability of receiving grants.

Since it is not possible to construct a variable to accurately assess the quality of an application at the project selection stage, indirect project potential indicators were used. The model comprised the following groups of variables (see Table 2 for their characteristics):

(1) Project leader: age, gender, number of WoS-indexed publications, academic degree;

(2) Project participants: total number, number of PhD holders aged under 35, characteristics of their organization (location, status (national research university (NRU), academic institute, etc.));

(3) Project application: amount of funding requested, expected number of publications in WoS-indexed journals based on the project results, multidisciplinary project or not.

To assess the interaction of factors, we have used a logistic regression model with the variable "Grant awarded or not". In the general form it looks as follows:

where:

$$
\ln (P /(1-P))=B_{0}+B_{1}^{*} \operatorname{Mark}_{\text {mean }}+\ldots+B_{26}^{*} N R U
$$

$\mathrm{P}$ - probability of receiving project support,

B1, ...B26 - coefficients with independent variables,

Mark_mean, ... NRU - independent variables.

Different variations of the model comprising different sets of independent variables were tested for robustness. In the first model, mean scores were used as an independent variable; in the second, academic fields were added; in the third, a number of important other independent variables; and the fourth and final model included the full set of factors. 


\section{Table 2. Variables Used in the Analysis}

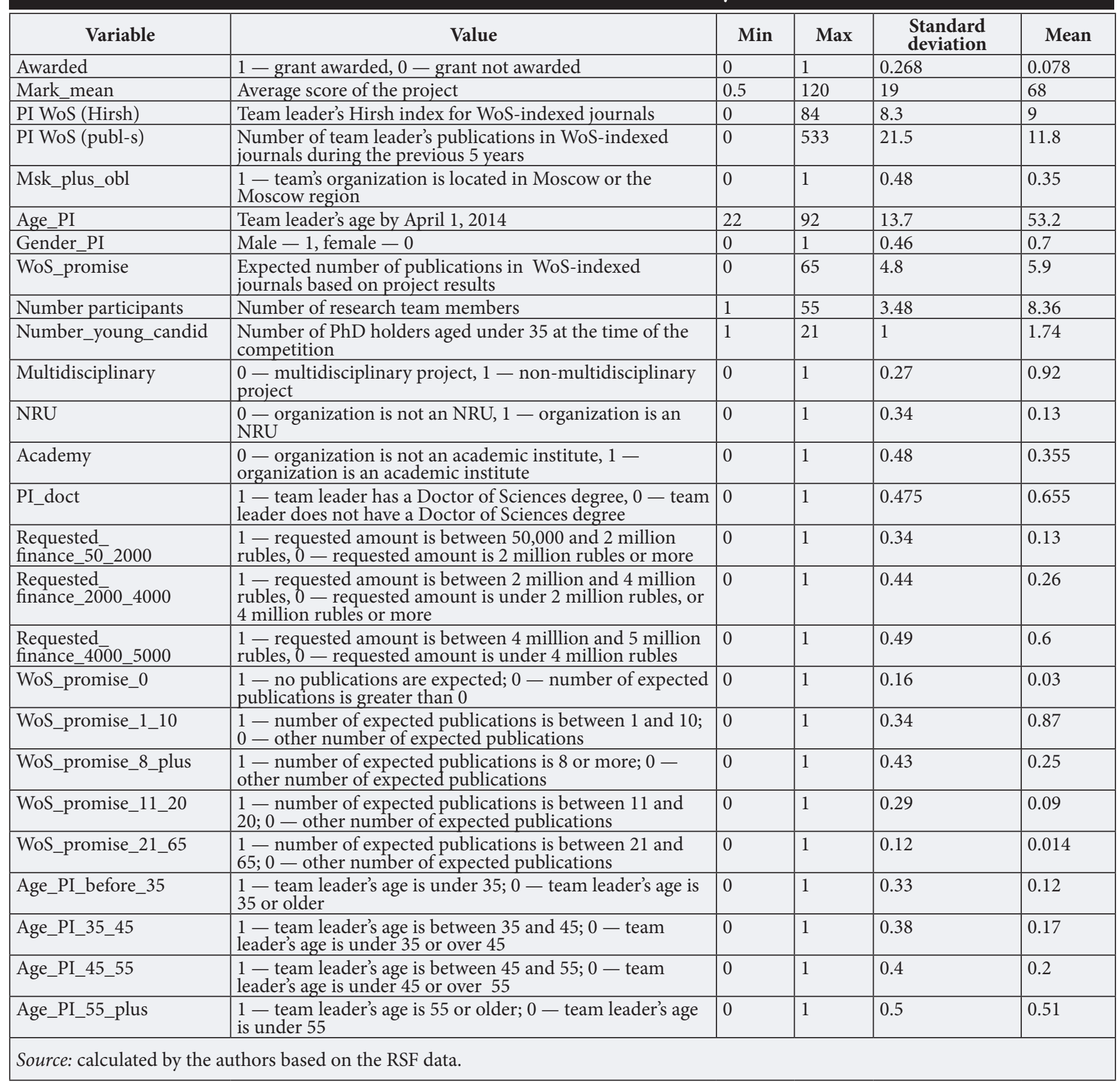

\section{Main Results}

Let us take a brief look at the most significant differences between the projects that have and those that have not been awarded grants (Table 3). It can be noted straightaway that the funding decisions were mostly based on the results of the peer review exercise.

The results of the RSF competition for grants to support basic research projects in various knowledge areas show that most frequently grants were awarded to projects in the life sciences. This was probably due to the foundation's default objective to compensate for the inadequate attention paid by the conventional research funding system to academic fields directly connected with meeting people's needs, such as biology, medicine, and agriculture. A descriptive analysis revealed that the projects proposed by larger teams, headed by men, holders of PhDs, and of a noticeably more advanced age than their unlucky colleagues, were treated more favorably. However, any high-quality research project tends to have some of these characteristics. Compared with the structure of the total body of submitted applications, the winners included a higher share of academic institutes and organizations based in Moscow and the Moscow region. This, however, may simply be due to the high concentration of leading scientists at the Russian Academy of Sciences, and at research institutes based in Moscow.

The publication activity of project teams' members, and especially their leaders, turned out to be a very important factor affecting selection results (Table 4). Significant differences were also found between various academic fields, reflecting not so much the latter's specific features as the particulars features of their development in Russia, i.e., integration in, or, on the contrary, isolation from, the international context. 


\section{Table 3. Comparative Characteristics of Projects that Were and Those that Were not Awarded Grants in the First RSF Competition}

\begin{tabular}{|c|c|c|c|}
\hline Indicators & $\begin{array}{l}\text { Awarded } \\
\text { projects }\end{array}$ & $\begin{array}{l}\text { Rejected } \\
\text { projects }\end{array}$ & $\begin{array}{l}\text { All } \\
\text { applications }\end{array}$ \\
\hline Average project score & 98.7 & 65.4 & 68 \\
\hline Average team leader age & 56.7 & 52.9 & 53.2 \\
\hline Share of male team leaders (\%) & 85 & 69 & 70 \\
\hline $\begin{array}{l}\text { Average number of team leaders' publications in WoS-indexed journals over the } \\
\text { previous } 5 \text { years }\end{array}$ & 26.7 & 10.3 & 11.6 \\
\hline Team leader's Hirsh index for WoS-indexed journals & 14.8 & 7.8 & 9 \\
\hline Share of team leaders with a $\mathrm{PhD}(\%)$ & 85.3 & 63.8 & 65 \\
\hline Average number of team members & 11 & 8.13 & 8.4 \\
\hline Average number of young $\mathrm{PhD}$ holders aged under 35 on the team & 2.14 & 1.7 & 1.7 \\
\hline Average requested amount of grant funding (thousand rubles) & 4624 & 3764.4 & 3831.4 \\
\hline $\begin{array}{l}\text { Average number of expected publications in WoS-indexed journals based on } \\
\text { project results }\end{array}$ & 8.4 & 5.6 & 5.9 \\
\hline Share of applicants from NRUs (\%) & 9.3 & 13.3 & 13 \\
\hline Share of applicants from academic institutes (\%) & 59.2 & 33.5 & 36 \\
\hline Share of teams based in Moscow or the Moscow region (\%) & 52 & 34 & 35 \\
\hline Share of multidisciplinary projects (\%) & 9 & 7.7 & 8 \\
\hline Share of projects in social sciences (\%) & 10.7 & 31.9 & 30.2 \\
\hline Share of projects in biology and medicine (\%) & 31.2 & 17.3 & 18.3 \\
\hline Share of projects in mathematics, physics, and chemistry (\%) & 35 & 30.1 & 30.5 \\
\hline
\end{tabular}

In order to reveal possible partiality in project selection, a regression analysis was conducted using four specifications with the different sets of independent variables (see Table 5), supplemented by a knowledge area-specific regression analysis (Table 6). It can be noted straight away that expert-assigned scores turned out to be significant in all specifications, with the highest marginal effect for this explanatory variable.

Individual expert assessments, which in a number of cases provided certain guidance to the RSF council when it selected applications to receive grants, especially when expert opinions clashed, could differ from the relevant council section's final position. The level of such a divergence generally tended to be knowledge area-specific, depending upon the degree of the area's integration into the global context and its practical focus. For example, expert opinions on "hard science" projects usually were less contradictory than those regarding "soft" ones. Specific council sections' general predisposition towards the active or on the contrary, the evolutionary development of relevant subject areas seems to be no less important. The greatest unanimity was demonstrated by such expert council sections as the engineering sciences, earth sciences, physics, and chemistry. Projects in mathematics, biology, medicine, social sciences, and the humanities required the most significant adjustments (see Table 6).

As to partiality regarding project leaders, the regression model revealed no gender inequality in project selection: this factor was insignificant in the third and fourth specifications alike. At the same time,

\section{Table 4. Comparison of the Publication Activity of the Leaders of Awarded and Rejected Projects in WoS- and RSCI-indexed Journals, by Knowledge Area}

\begin{tabular}{|c|c|c|c|c|c|}
\hline \multirow[t]{2}{*}{ Knowledge area } & \multirow[t]{2}{*}{ Entry requirement for team leader } & \multicolumn{2}{|c|}{$\begin{array}{c}\text { Median number of WoS } \\
\text { publications in } 5 \text { years' time }\end{array}$} & \multicolumn{2}{|c|}{$\begin{array}{c}\text { Median number of RSCI } \\
\text { publications in } 5 \text { years' time }\end{array}$} \\
\hline & & awarded & rejected & awarded & rejected \\
\hline Mathematics & $\geq 3 \mathrm{WoS} /$ Scopus publications & 14 & 7 & 24 & 16 \\
\hline Physics & $\geq 3 \mathrm{WoS} /$ Scopus publications & 27 & 13 & 32.5 & 19 \\
\hline Chemistry & $\geq 3 \mathrm{WoS} /$ Scopus publications & 36 & 11 & 44 & 21 \\
\hline Biology & $\geq 3 \mathrm{WoS} /$ Scopus publications & 19 & 8 & 21 & 14 \\
\hline Medicine & $\geq 3 \mathrm{WoS} /$ Scopus publications & 18 & 7 & 34 & 22 \\
\hline Agriculture & $\geq 3 \mathrm{WoS} /$ Scopus publications & 8.5 & 5 & 23 & 21 \\
\hline Earth sciences & $\geq 3 \mathrm{WoS} /$ Scopus publications & 12 & 7 & 27 & 15 \\
\hline $\begin{array}{l}\text { Social sciences, } \\
\text { humanities }\end{array}$ & $\begin{array}{l}\geq 3 \text { WoS/Scopus or RSCI publications } \\
\text { (or a peer-reviewed monograph) }\end{array}$ & 2 & 0 & 23 & 13 \\
\hline Engineering sciences & $\begin{array}{l}\geq 3 \mathrm{WoS} / \text { Scopus publications or } \geq 2 \text { such } \\
\text { publications and } 2 \text { legally protected results of } \\
\text { intellectual activities }\end{array}$ & 16 & 4 & 31 & 18 \\
\hline
\end{tabular}




\section{Table 5. Results of the Regression Analysis of the Awarding of Grants to Support Research Projects in the First RSF Competition}

\begin{tabular}{|c|c|c|c|c|}
\hline Indicators & Specification (1) & Specification (2) & Specification (3) & Specification (4) \\
\hline Variable & Coefficient value & Coefficient value & Coefficient value & Coefficient value \\
\hline Average project score & $0,292^{* * *}(0,010)$ & $0,367^{* * *}(0,013)$ & $0.365^{\star * \star}(0.013)$ & $0.367^{\star * \star}(0.014)$ \\
\hline Team leader's age under 35 & Not included in the model & Not included in the model & $0.912^{\star * \star}(0.31)$ & $1.019^{\star \star \star}(0.321)$ \\
\hline Team leader's age between $35-45$ & Not included in the model & Not included in the model & $0.548^{* *}(0.229)$ & $0.5778^{* *}(0.238)$ \\
\hline Team leader has $\mathrm{PhD}$ & Not included in the model & Not included in the model & $0.424^{\star \star}(0.199)$ & $0.409^{\star \star}(0.207)$ \\
\hline $\begin{array}{l}\text { Based in Moscow or the Moscow } \\
\text { region }\end{array}$ & Not included in the model & Not included in the model & n.s. & $-0.314^{\star \star}(0.136)$ \\
\hline Academic institute & Not included in the model & Not included in the model & $0.515^{\star * \star}(0.129)$ & $0.484^{\star \star \star}(0.145)$ \\
\hline Number of team members & Not included in the model & Not included in the model & $0.092^{\star \star \star}(0.018)$ & $0.105^{\star \star \star}(0.021)$ \\
\hline Multidisciplinary project & Not included in the model & Not included in the model & $-0.521^{* *}(0.225)$ & $-0.631^{* * *}(0.235)$ \\
\hline $\begin{array}{l}\text { Knowledge area taken into } \\
\text { account }\end{array}$ & No & Yes & Yes & Yes \\
\hline Number of observations & 11211 & 11211 & 11041 & 8761 \\
\hline Pseudo R2 & 0.64 & 0.71 & 0.72 & 0.714 \\
\hline \multicolumn{5}{|c|}{$\begin{array}{l}\text { Notes: }{ }^{* *}-\mathrm{p}<0.01,{ }^{* *}-\mathrm{p}<0.05,{ }^{*}-\mathrm{p}<0.1, \text { n.s. }- \text { not significant, standard errors shown in brackets; only significant variables ar } \\
\text { presented. }\end{array}$} \\
\hline
\end{tabular}

an opposite age bias was discovered compared with the trend revealed through the descriptive analysis, i.e., in favor of younger project leaders. On the whole, this matches the mainline parameters of efficient grant-based funding presented in [Lazeur, 1997]. However, the members of the expert council were hardly guided by such theories. Rather, the feelings of personal moral responsibility for the future careers of young scientists played a role. At the same time, a somewhat increased attention to applicants' status can still be detected: all other conditions being equal, research teams headed by $\mathrm{PhD}$ holders tended to be awarded grants more often.

Research teams' expectations regarding future publications based on project results ${ }^{6}$ generally did not significantly affect grant decisions, including for specific fields of research (with the exception of biology).

\section{Table 6. Regression Analysis Results for Specific Knowledge Areas (Significant Variables Only)}

\begin{tabular}{|c|c|c|c|c|c|c|c|c|}
\hline Variable & Mathematics & Physics & Chemistry & Biology & Medicine & $\begin{array}{l}\text { Earth } \\
\text { sciences }\end{array}$ & $\begin{array}{l}\text { Social } \\
\text { sciences }\end{array}$ & $\begin{array}{c}\text { Engineering } \\
\text { sciences }\end{array}$ \\
\hline Average project score & $\begin{array}{l}0.252^{* * *} \\
(0.032)\end{array}$ & $\begin{array}{l}0.798^{* * *} \\
(0.108)\end{array}$ & $\begin{array}{c}0.547^{\star * *} \\
(0.072)\end{array}$ & $\begin{array}{l}0.280^{\star * *} \\
(0.026)\end{array}$ & $\begin{array}{l}0.272^{* * *} \\
(0.028)\end{array}$ & $\begin{array}{c}0.793^{\star * *} \\
(0.147)\end{array}$ & $\begin{array}{l}0.362^{\star * *} \\
(0.046)\end{array}$ & $\begin{array}{l}1.697^{* * *} \\
(0.356)\end{array}$ \\
\hline $\begin{array}{l}\text { Team leader's number } \\
\text { of publications in WoS- } \\
\text { indexed journals }\end{array}$ & n.s. & n.s. & $\begin{array}{l}0.021^{\star} \\
(0.013)\end{array}$ & $\begin{array}{l}0.044^{* * *} \\
(0.015)\end{array}$ & $\begin{array}{l}0.017^{\star} \\
(0.010)\end{array}$ & n.s. & n.s. & n.s. \\
\hline $\begin{array}{l}\text { Team leader's gender } \\
(1-\text { male })\end{array}$ & $2.953^{\star *}(1.26)$ & n.s. & n.s. & n.s. & n.s. & n.s. & n.s. & n.s. \\
\hline $\begin{array}{l}\text { Team leader's age }-55 \\
\text { or older }\end{array}$ & n.s. & n.s. & n.s. & n.s. & n.s. & n.s. & $\begin{array}{c}\text { n.s. } \\
\text { (borderline) }\end{array}$ & n.s. \\
\hline $\begin{array}{l}\text { Moscow and the Moscow } \\
\text { region }\end{array}$ & n.s. & n.s. & n.s. & $\begin{array}{c}-0.955^{\star * *} \\
(0.341)\end{array}$ & n.s. & n.s. & $\begin{array}{c}-0.903^{\star *} \\
(0.450) \\
\end{array}$ & n.s. \\
\hline Academic institute & $\begin{array}{l}1.544^{* * *} \\
(0.439)\end{array}$ & $1.05^{\star}(0.61)$ & n.s. & n.s. & n.s. & n.s. & n.s. & n.s. \\
\hline $\begin{array}{l}\text { Number of young PhD } \\
\text { holders (under } 35 \text { ) }\end{array}$ & n.s. & n.s. & n.s. & $\begin{array}{c}-0.267^{\star} \\
(0.15)\end{array}$ & n.s. & n.s. & n.s. & n.s. \\
\hline $\begin{array}{l}8 \text { or more publications } \\
\text { expected }\end{array}$ & n.s. & n.s. & n.s. & $\begin{array}{l}0.659^{*} \\
(0.357)\end{array}$ & n.s. & n.s. & $\begin{array}{c}\text { n.s. } \\
\text { (borderline) }\end{array}$ & n.s. \\
\hline Multidisciplinary project & n.s. & n.s. & n.s. & n.s. & $\begin{array}{l}-1.54^{* * *} \\
(0.589)\end{array}$ & n.s. & $\begin{array}{l}-2.860^{\star *} \\
(1.434)\end{array}$ & n.s. \\
\hline $\begin{array}{l}\text { Number of team } \\
\text { members }\end{array}$ & n.s. & n.s. & $\begin{array}{l}0.276^{* * *} \\
(0.093)\end{array}$ & n.s. & n.s. & $\begin{array}{c}0.355^{\star * *} \\
(0.108)\end{array}$ & n.s. & $\begin{array}{l}0.297^{* *} \\
(0.149)\end{array}$ \\
\hline Number of observations & 733 & 1237 & 1258 & 1047 & 877 & 665 & 1552 & 1283 \\
\hline Pseudo R2 & 0.55 & 0.84 & 0.84 & 0.67 & 0.64 & 0.84 & 0.71 & 0.94 \\
\hline
\end{tabular}


We believe this can be explained by researchers' inclination to recognize less than realistic publication plans. For example, some of the applicants promised to prepare more than 40 papers for publication in WoS-indexed journals even though the leaders of these teams had not published a single such paper over the course of the last five years.

Larger teams tended to have a certain advantage during the selection of projects, which is rather hard to explain. According to some studies, for example, [Park et al., 2015], team size can make a positive impact on project quality. However, in our opinion, for many teams, the RSF funding was a way to increase their total earnings but they were not actually prepared to compete for grants in earnest. Regarding multidisciplinary projects, the regression analysis yielded an effect directly opposite to the one observed during the selection process: all other conditions being equal, this factor negatively affected grant awarding. We believe this is due to the burdensome requirement to receive the approval of at least two sections of the expert council.

Reservations about the impartiality of rewarding grants to projects proposed by academic institutes on the whole were confirmed: the experts did tend to treat them preferentially. A possible explanation for this is the high share of representatives of academic organizations on the foundation's expert council: about six RAS staff members per university employee. However, another theory seems to be more convincing. At the beginning of 2014, when the competition took place, academic institutes were undergoing the painful process of organizational and financial transformation, so colleagues felt obliged to help researchers employed by these organizations. As to regional distribution, the hypothesis about projects proposed by Moscow and Moscow region-based organizations receiving favorable treatment was not confirmed. The foundation's experts probably believed that it was the provincial organizations that needed research funding the most. Supporting research and promoting the emergence of a favorable innovation environment in the regions is believed to be an important component of the relevant foundations' activities the world over. In particular, the analysis of the NSF project selection practices [Arora, Gambardella, 2005] also revealed a "positive discrimination" regarding this feature: regional projects had the best chances of receiving grants.

\section{Discussion of the Results}

The following questions seem to be relevant regarding the provision of support for basic research, in particular, and the advancement of Russian science policy in general:

How closely did the project selection results match the opinion of the academic community, i.e., the expertassigned scores?

Peer review remains the main project selection mechanism. Occasionally, an evaluation by external experts is used, but peer review generally implies an assessment by fellow researchers. Contrary to certain statements, the qualifications of RSF experts (somewhat arbitrarily measured by the number of their publications in WoS- or Scopus-indexed journals) was comparable with that of the research team leaders, though lower than the winners'. The involvement of the practicing researchers in project selection has both positive and negative aspects. The first positive aspect includes their professionalism and the relevance of their opinions, the dissemination of various approaches and ideas across the academic environment, and the emergence of new collaborations. The costs of this approach, especially when only Russian experts are recruited to assess applications (which was quite common during the early period of the RSF), involve clique-like seclusion, conflicts of interest, and occasionally even the risk of inadequate selection due to the insufficient level of Russian science in certain academic fields.

The actual results of the RSF project selection provide evidence of the high priority given to expert opinions: the empirical analysis revealed that the average expert-assigned score played a decisive role in the award of grants.

What contribution did the awarded grants actually make?

Giving a valid answer to this question would require reviewing the results of supported projects and comparing them with those of rejected ones. However, it can already be noted that in all knowledge areas, the leaders of successful research teams had already published several times more papers in peerreviewed journals and had several times higher Hirsh index scores for WoS-indexed journals than their less successful colleagues. We are not inclined to overestimate the importance of these indicators, but as statistical tools they are quite useful. It would not be a great exaggeration to state that the first RSF competition managed to successfully identify unique members of the Russian research community. And this, that is, supporting world-class research and researchers, was the overall objective of founding the RSF in the first place.

Keeping in mind the inevitable errors the first and second types of evaluation made during project selection, and the financial limitations that the RSF had to face, we must note that not all worthy projects were supported. On the whole, it can be said that the grants were awarded in line with meritocratic principles.

Did the experts share any ideologically similar inclinations, partiality, or biases?

In our opinion, the favorable treatment of larger projects teams and projects proposed by regional academic institutes fits the academic community's traditional paternalistic model, which combines competition with social equality. Two sets of logic clashed when grant decisions were made: rewarding achievements $v s$. encouraging development, a project-based approach $v s$. regular, ongoing funding. We believe that the pronounced social motives arose over the course of the selection process due to the unbalanced structure of the Russian basic research funding system, primarily the lack of basic funding. 
The distorted motivation of the RSF applicants was largely due to a lack of other sources of basic research funding. For many research teams, the foundation's money was a matter of survival, which prompted them to submit applications and apply various forms of indirect pressure. Such an overload on science foundation-operated grant allocation systems caused by the limited availability of other basic funding sources was also noted in countries where the research sector received much more generous support. Active fundraising appears to play a positive role, expanding the opportunities for selecting the best projects. On the other hand, it reflects the decline of previously available opportunities combined with direct administrative encouragement. In particular, certain institutes and universities began to adopt targets for securing RSF grants, and sometimes for the submission of applications as well.

How did the first RSF competition affect researchers' behavior and motives?

Firstly, it prompted researches to review and self-select their proposals before actually submitting an application to the science foundation, and treat their obligations more responsibly. Secondly, their personal motives for publishing in internationally peer-reviewed journals increased, while the editorial boards of Russian academic journals discovered additional incentives to get indexed by Scopus and WoS databases. Thirdly, the research community now recognizes the need to regulate ethical issues. Fourthly, there is stronger demand for able team leaders capable of setting ambitious research objectives and accomplishing them by implementing relevant projects and recruiting professionals from various organizations.

The important thing here is the emergence of a strong trend towards improving general RSF procedures, as opposed to making sensible but narrow-minded decisions. Practice shows that the research community is the main source of the best rules and practices, provided that science foundations steadily and strictly adhere to such rules afterwards.

The preliminary results of this study were presented at the HSE April International Academic Conference on Economic and Social Development (Moscow, April 19, 2016). Some of the additional results and interpretations were presented at the GSOM Emerging Markets Conference hosted by the Graduate School of Management of St. Petersburg State University (October 6, 2016.).

\section{References}

ANR (2015) Annual Report 2015, Paris: Agence Nationale de la Recherche.

Antonelli C., Crespi F. (2011) Matthew Effects and R\&D Subsidies: Knowledge Cumulability in High-tech and Low-tech Industries (Working paper 11/2011), Rome: University 'Roma Tre'.

Arora A., Gambardella A. (2005) The impact of NSF support for basic research in economics. Annales d'Economie et de Statistique, no 79-80, pp. 91-117.

Benos D.J., Bashari E., Chaves J.M., Gaggar A., Kapoor N., LaFrance M., Mans R., Mayhew D., McGowan S., Polter A., Qadri Y., Sarfare S., Schultz K., Splittgerber R., Stephenson J., Tower C., Grace W.R., Zotov A. (2007) The ups and downs of peer review. Advances in Physiology Education, vol. 31, no 2, pp. 145-152.

Gush J., Jaffe A.B., Larsen V., Laws A. (2015) The Effect of Public Funding on Research Output: The New Zealand Marsden Fund (NBER Working Paper no w21652), Cambridge, MA: National Bureau of Economic Research.

Jacob B.A., Lefgren L. (2011) The impact of research grant funding on scientific productivity. Journal of Public Economics, vol. 95, no 9, pp. 1168-1177.

Khlunov A.V. (2014) Khoroshikh zayavok v dva s polovinoi raza bol'she, chem grantov [There is two and a half more good applications than available volume of grants (interview)]. Gazeta.Ru, 23.05.2014. Available at: http://www. gazeta.ru/science/interview/nm/s6040141.shtml, accessed 12.07.2016 (in Russian).

Klimenko A.V. (2014) Vsyo po chestnomu. Uchenye otsenyat ob'jectivnost' ekspertizy RNF (intervyu) [All is fair. Scientists will evaluate objectiveness of the RSF's expertise (interview)]. Nauchnoe obozrenie, 28.05.2014. Available at: http://scientific.ics.org.ru/news/uchenye-ocenyat-obektivnost-ekspertizy-rnf, accessed 12.07.2016 (in Russian).

Lazeur E.P. (1997) Incentives in Basic Research. Journal of labour Economics, vol. 15, no 1, part 2: Essays in Honor of Yoram Ben-Porath, pp. S167-S197.

Li D., Agha L. (2015) Big names or big ideas: Do peer-review panels select the best science proposals? Science, vol. 348 (6233), pp. 434-438.

Merton R.K. (1968) The Matthew Effect in Science. Science, vol. 159 (3810), pp. 56-63.

Mowery D. (1990) The Growth of U.S. Industrial Research, Berkeley, CA: University of California (mimeo).

Nelson R. (1959) The simple economics of basic scientific research. The Journal of Political Economy, vol. 67, no 3, pp. 297-306.

Park H., Lee J.J., Kim B.C. (2015) Project selection in NIH: A natural experiment from ARRA. Research Policy, vol. 44, no 6, pp. 1145-1159.

Pavitt K. (1991) What makes basic research economically useful? Research Policy, vol. 20, no 2, pp. 109-119.

RSF (2015) Otchet Rossiiskogo nauchnogo fonda za 2014 god [RSF Annual Report 2014], Moscow: Russian Science Foundation (in Russian).

Smith R. (2006) Peer review: A flawed process at the heart of science and journals. Journal of the Royal Society of Medicine, vol. 99, no 4, pp. 178-182. 


\title{
What Impedes Universities from Creating Dual-Purpose Technologies?
}

\author{
Mikhail Kuzyk ${ }^{\text {a }}$ \\ Head of Division, kuzyk@iacenter.ru
}

Anna Grebenyuk ${ }^{\text {b }}$

Deputy Head, Department for Strategic Foresight, Institute for Statistical Studies and Economics of Knowledge, grebenyuk@hse.ru

Evgenia Kakaeva ${ }^{\text {a }}$

Head of Division, kakaeva@iacenter.ru

Evgeniy Manchenko ${ }^{\text {a }}$

Deputy General Director, mev@iacenter.ru

Vladimir Dovgiy ${ }^{\text {a }}$

General Director, dovgiy@iacenter.ru

\author{
${ }^{a}$ Interdepartmental Analytical Center, P.O. Box 35, 31/29, Povarskaya str, Moscow 121069, Russian Federation \\ b National Research University Higher School of Economics, 20, Myasnitskaya str., Moscow 101000, Russian Federation
}

\begin{abstract}
$\mathrm{M}$ odern universities play a significant role, and in some countries, a critical role in research and development (R\&D) on a wide variety of topics, often they concern national security. US university science is an illustrative example in this regard, it is an important source of knowledge and technology for military departments and its industrial counterparts. However, even with the large number of theoretical and empirical studies focusing on different aspects of university research innovation activities, so far, the problems of the development of military or dualuse technologies by universities has been poorly covered in economic literature.

In this article, the specifics of university science participation in defense research and development is examined using the example of the Russian higher education institutes. It is shown that Russian universities are poorly

involved in defense-related activities. Based on data from a sample survey of 80 universities, and the analysis of certain public policies on science and innovation, the authors concluded that higher education institutions have considerable potential for performing $\mathrm{R} \& \mathrm{D}$ activities for the defense industry. The actual problems and obstacles impeding the development of university research activities in the interests of the defense industry are identified, including the traditional focus of industrial companies on their own research divisions and sectoral research institutes and design bureaus, weak information about the current opportunities and achievements of university science, and the inadequate activity of universities in promoting their own research competencies and an image of advanced R\&D centers. Possible ways of solving the existing problems are put forward for consideration.
\end{abstract}

Keywords: higher education; university science; research and development; dual-purpose technology; universityindustry collaboration; defense industry; science and technology priorities

Citation: Kuzyk M., Grebenyuk A., Kakaeva E., Manchenko E., Dovgiy V. (2017) What Impedes Universities from Creating Dual-Purpose Technologies? Foresight and STI Governance, vol. 11, no 4, pp. 84-95. DOI: 10.17323/2500-2597.2017.4.84.95 
$\mathrm{U}$ niversities play an increasingly important role in supporting national economies' competitiveness by efficiently combining educational, research ${ }^{1}$, and entrepreneurial activities. They not only train specialists, create, preserve, and transfer knowledge, but also actively establish innovative companies, develop and implement new technologies, and contribute to economic growth [Etzkowitz et al., 2000; Etzkowitz, 2003].

Over the previous two decades, the role of educational organizations as a source of technologies for the market has steadily grown in developed countries [Henderson et al., 1998; Caloghirou et al., 2004; etc.]. According to the Triple Helix model, knowledge-based economic growth is fuelled by universities cooperation with industry and the state [Etzkowitz, Leydesdorff, 1995, 2000; Etzkowitz, 2003]. Furthermore, the current "hybrid" configuration of the Triple Helix model (it is the third such model, following the "etatistic" and "laissez-faire" varieties) sees universities as the core and as the main drivers of innovative activities [Etzkowitz, Leydesdorff, 2000; Etzkowitz et al., 2000; Abd Razak, White, 2015]2.

A key area for implementing the higher education sphere's research and innovation potential is the creation of knowledge, products, and technologies initially designed for security and defense purposes, or with the potential for special- or dual-purpose application. The US experience is particularly revealing, where universities annually receive between $10 \%$ and $13 \%$ of the Department of Defense's (DoD) total research and development (R\&D) appropriations [Pankova, 2016]. Evidence of the military agency's increased attention to universities' research capabilities is the application of funding tools designed exclusively for these organizations. For example, the objective of the DURIP program (Defense University Research Instrumentation Program) is to provide them with the equipment they need to execute DoD orders. ${ }^{3}$ The MURI program (Multidisciplinary University Research Initiatives Program) provides funding for multidisciplinary university research whose results, in addition to defense-related applications, also have market potential ${ }^{4}$.

The US universities' contribution to the country's defense is not limited to executing direct orders for military and dual-purpose R\&D. Twelve University Affiliated Research Centers (UARCs) are operating in the US, plus two Federally Funded Research and Development Centers (FFRDCs) also run by universities and regularly funded by the defense department ${ }^{5}$.

The US Defense Advanced Research Projects Agency (DARPA) pays considerable attention to strengthening partnerships with universities covering a wide range of areas from basic research to applied development. The agency's mandate includes identifying university projects with no apparent military or commercial applications, but with significant potential for practical implementation. DARPA funds basic and applied research by companies, universities, and non-governmental R\&D organizations, promotes cooperation between universities and businesses, the discussion of promising ideas, and the creation of relevant communities [Popova, 2010; Pankova, 2016; DARPA, 2016].

A number of theoretical and empirical studies of various aspects of universities' research and innovation activities have been published, including their cooperation with companies [Clark, 1998; MeyerKrahmer, Schmoch, 1998; Etzkowitz et al., 2000; Siegel, 2003; D’Este, Patel, 2007; Perkmann, Walsh, 2007; etc.]. However, no detailed studies of defense-oriented research have yet been conducted. Scientists do touch upon this subject while analyzing the activities of defense agencies and services cooperating with universities, such as DARPA or the UK's Defence Evaluation and Research Agency (DERA), but beyond noting the fact of such partnerships, authors do not provide a detailed analysis of relevant issues [MolasGallart, Sinclair, 1999; Popova, 2010].

A specific feature of the Russian research sector inherited from the Soviet period is the domination of "conventional" R\&D organizations such as institutes of the state academies of sciences, and research institutes and design bureaus administered by various government ministries. The role of universities in this sphere traditionally was, and remains, quite modest. For example, in 2015, the higher education sector's share of the country's gross domestic expenditures on R\&D (GERD) was less than $10 \%$, and they employed about $12 \%$ of all Russian researchers. Still, the importance of university science did grow, especially during the 2008-2011 post-recession recovery (Figure 1). The government tried to learn from the lessons of the crisis and promote economic growth of a "new kind", thus encouraging universities' activities de facto became a major priority of the science, technology, and innovation (STI) policy [Kuzyk, Simachev, 2013].

Compared with 2000, the higher education sector's share of total GERD has more than doubled (Figure 2). Still, in this regard Russia remains far behind not only the countries that traditionally adhere to the university-based R\&D model, but even behind some of the former socialist countries and Soviet republics [Gokhberg et al., 2009; Gokhberg, Kuznetsova, 2011]. Russian universities' R\&D cooperation with businesses does not look very impressive either (Figure 2).

However, the current Russian situation with universities' research and innovation activities is not at all unique. Many former Soviet republics and socialist states are in the same position, with universities'

\footnotetext{
${ }^{1}$ In the middle of the $20^{\text {th }}$ century, the prevailing view of universities was as "pure science" actors at the source of scientific progress [Gertner, 2013; Hirschi, 2013].

2 The main thesis of the Triple Helix theory is that knowledge creation institutions dominate the innovation system, and in many countries, universities are believed to be the most important of these [Dezhina, Kiseleva, 2007].

${ }^{3}$ See: https://www.onr.navy.mil/Science-Technology/Directorates/office-research-discovery-invention/Sponsored-Research/ University-Research-Initiatives/DURIP for more (last accessed on 14.11.2017).

${ }^{4}$ See: https://www.onr.navy.mil/Science-Technology/Directorates/office-research-discovery-invention/Sponsored-Research/ University-Research-Initiatives/MURI for more (last accessed on 14.11.2017).

${ }^{5}$ See: https://www.nsf.gov/statistics/ffrdclist/ for more (last accessed on 14.11.2017).
} 


\section{Figure 1. Relative Indicators of Universities' Research Activities in 2000-2015}

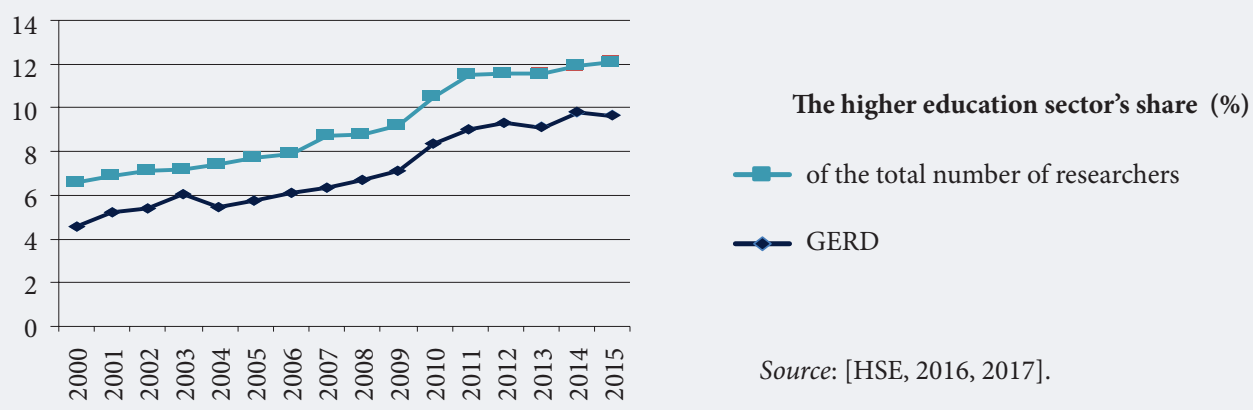

research remaining secondary compared with that of "major league" players, i.e., specialized institutes and laboratories [Glänzel, Schlemmer, 2007; Altbach et al., 2009]. A similar picture can be observed in a number of Western European countries (Italy, Spain, Portugal), Latin America (Argentina, Chile, Mexico, Brazil, Columbia), and South-East Asia (Thailand, Philippines), etc. (Figure 3)

This paper analyzes specifically Russian features of higher education organizations' participation in military, special- and dual-purpose R\&D in the present-day context. The scale of such activities is estimated, along with universities ' willingness to step them up, the availability of required capabilities and competencies, and the limiting factors. Recommendations are put foward to increase universities' contributions to the development of the defense industry, and of the industrial sector in general.

\section{Universities' Potential and Scope of Participating in Defense and Dual- Purpose R\&D}

\section{Defense R\&D}

Defense-related $\mathrm{R} \& \mathrm{D}$ is a quite large and promising area. According to open source data, relevant expenditures rapidly grew during over the last few years (Figure 4). For example, in 2015, R\&D funding allocated as part of state defense order has more than doubled compared with 2012 (122\% average annual growth). To compare, budget appropriations for civil R\&D during the same period grew by less than a quarter (average annual growth 109\%).

No statistics are available on Russian universities' defense-related R\&D. Nevertheless, the available data allows one to estimate the share of universities' R\&D in priority S\&T development areas for Russia that

\section{Figure 2. Universities' Research Activities: An International Comparison}

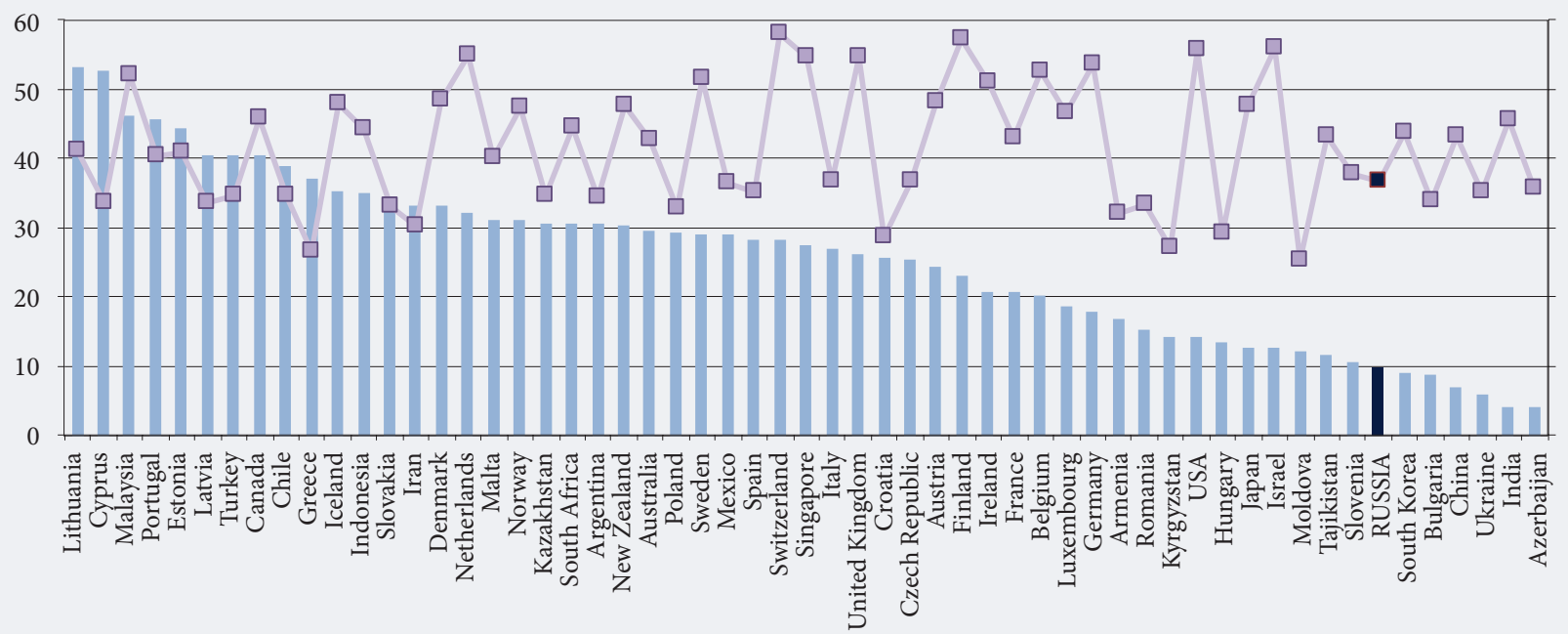

The higher education sector's share of GERD in 2015 (or the closest available data): left scale

$\square-$ Index of universities' R\&D cooperation with industrial companies (2016 GII): right scale 
Figure 3. The University Sector's Indicators and Cooperation with Industrial Companies: 2016

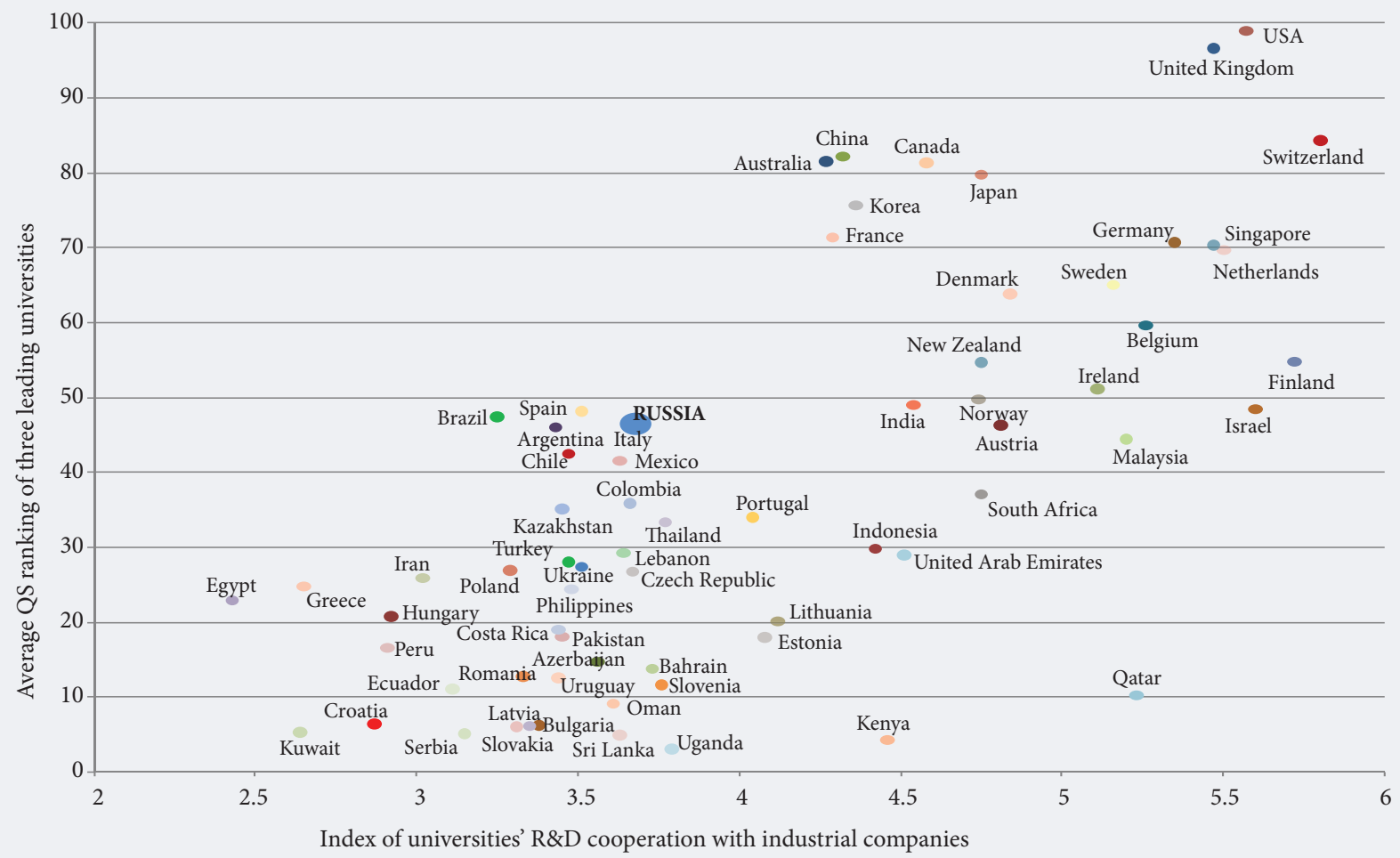

Sources: composed by the authors on the basis of [WEF, 2016; Cornell University et al., 2017].

fall outside the scope of civil segments. ${ }^{6}$ The relevant figure is quite small (about 10\% in 2015), and shows no pronounced growth (at least not over the previous decade) (Figure 5).

A survey of R\&D and higher education organizations conducted by the Interdepartmental Analytical Center (IAC) in $2012^{7}$ provides a general idea about the extent of universities' involvement in defenserelated R\&D.

Universities participated in R\&D in civil priority $S \& T$ development areas more actively than "mainstream" R\&D organizations did. However, in the defense and national security domain, the situation was quite different: $16 \%$ of the surveyed R\&D organizations conducted such research, compared with just 7\% of universities. Note that the "most defense-related" priority area - advanced weapon, military, and special technology - turns out to be the least represented, with only $2 \%$ of the universities in the sample conducting such research. On the contrary, it was one of the most popular research areas for R\&D organizations: $13 \%$ of the surveyed research institutes conducted relevant research (Figure 6).

According to IAC experts, total expenditures on defense-related R\&D conducted by higher education and research organizations supervised by the Russian Ministry of Education and Science on the basis of direct contracts with the Russian Ministry of Defense in 2015 amounted to just about 200 million rubles, or less than $0.1 \%$ of the overall volume of public $R \& D$ in the state defense order. To compare, US universities get at least 10\% of the DoD's R\&D expenditures. It should be kept in mind though that the most common format of involving universities in defense R\&D in Russia is through procurement orders placed not directly by the Ministry of Defense but by various defense industry companies and their integrated structures (the reasons for this arrangement will be discussed below). Even so, according to the IAC, such companies' expenditures in 2015 amounted to only about 3 billion rubles (out of that 2.3 billion went directly to universities, and about 700 million to engineering centers established by them), or just over $1 \%$ of $R \& D$ conducted in the framework of state defense order.

Thus, Russian universities remain poorly involved in defense-related R\&D due to their low levels of related activity and specific features of public defense-related procurement (see below).

\footnotetext{
${ }^{6}$ Out of the nine priority S\&T development areas approved by the President of Russia (Executive order No. 899 of July 7, 2011), six can be notionally classified as civil: nanosystems; information and telecommunication systems; life sciences; efficient environmental management; transport and space systems; energy efficiency and energy saving; and nuclear energy. The other three priority areas belong in the national security and defense domain: security and counterterrorism; advanced weapon, military, and special technology; military, special- and dual-purpose robotic complexes (systems).

7 The survey was conducted in 2012 by the IAC with support of the HSE Institute for Statistical Studies and Economics of Knowledge Centre for Business Trend Studies and the Information and Publishing Center "Statistics of Russia". The heads of Russian R\&D and higher education organizations were surveyed using a formalized questionnaire specially designed by the IAC. The total sample included $361 \mathrm{R} \& \mathrm{D}$ organizations: 109 universities and 252 research institutes (for more about the survey and its results see, e.g., [Simachev et al., 2015]).
} 


\section{Figure 4. Growth of Federal Budget Appropriations for Civilian and Military R\&D}

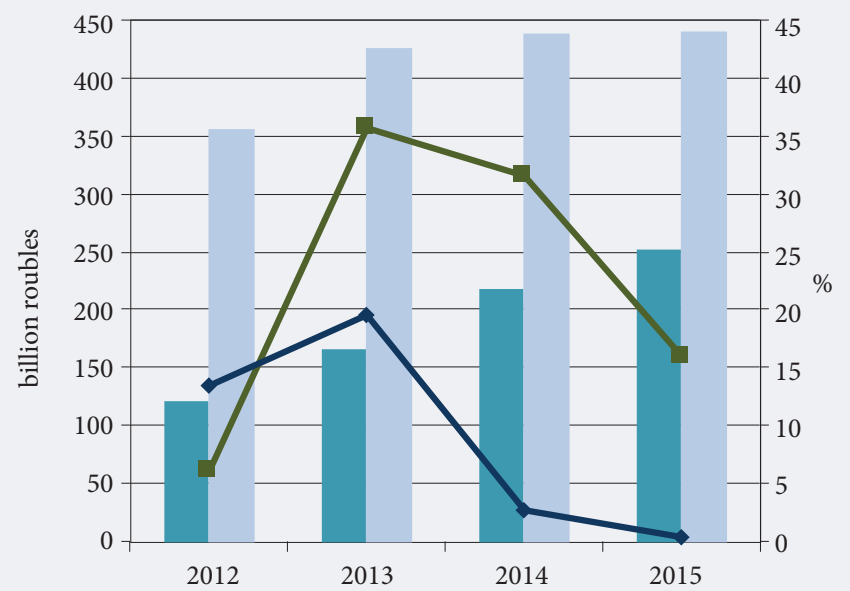

Federal budget appropriations for R\&D in the framework of state defense order, relevant years' prices (left scale)

Federal budget appropriations for civil R\&D, relevant years' prices (left scale)

Sources: [Frolov, 2016; HSE, 2017], authors' calculations.

\section{Dual-purpose R\&D}

The aforementioned situation regarding universities' poor involvement in defense-related R\&D raises a question about their ability to make a more significant contribution in this area, i.e., the availability of the relevant S\&T groundwork results and competencies.

In late 2016-early 2017, IAC experts conducted an integrated sample assessment of 80 Russian universities' potential to perform defense-related R\&D. The selected universities were interested in such work and in cooperating with the Ministry of Defense. ${ }^{8}$ Having such an interest was used as university selection criterion, as opposed to having relevant practical experience. This allowed for focusing on universities willing carry out defense-related R\&D and develop relevant competencies, but still lacking close ties with the Ministry of Defense. Universities that did not see defense-related areas as research priorities have not been considered. The main sources of data for the integrated assessment included a questionnairebased survey and in-depth interviews. They were conducted in 2016 covering 80 and 11 universities, respectively. Universities' potential to conduct $\mathrm{R} \& \mathrm{D}$ for industrial production purposes was analyzed (or their capability to build one quickly); competitiveness in the relevant subject areas; and experience working for the defense industry, including the execution of procurement orders placed by defense companies. The respondents were rectors (vice-rectors) and the heads of relevant university departments. Also, the following additional data sources were used:

\section{Figure 5. GERD on Priority S\&T Development Areas}

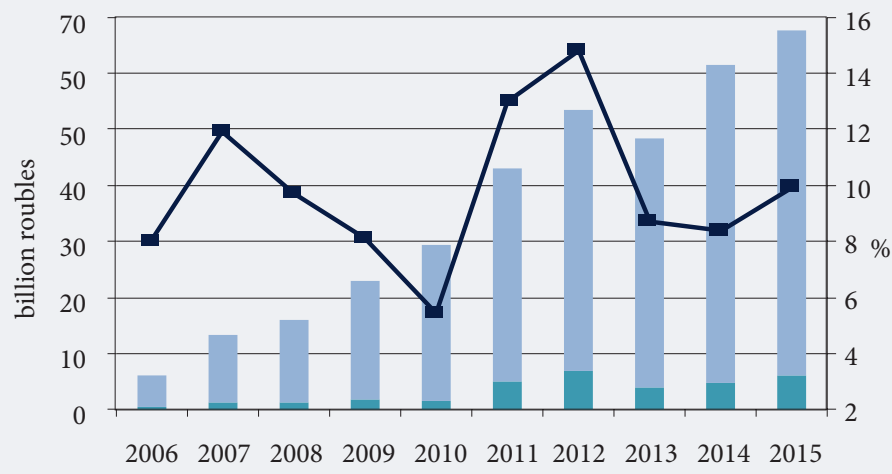

Total GERD on priority S\&T development areas, relevant years' prices (left scale)

out of that, GERD outside civil priority areas (left scale)

- Share of GERD in priority S\&T development areas outside civil priority areas (right scale)

Sources: [HSE, 2008, 2009, 2010, 2011, 2012, 2013, 2014, 2015, 2016, 2017], authors' calculations.

\footnotetext{
${ }^{8}$ The following indicators were used to detect universities' interest in stepping up R\&D cooperation with the Russian Ministry of Defense: official documents signed by management (letters, etc.); the appointment of an official to coordinate such cooperation; making one or more university departments officially responsible for carrying out R\&D for the Russian Ministry of Defense.
} 


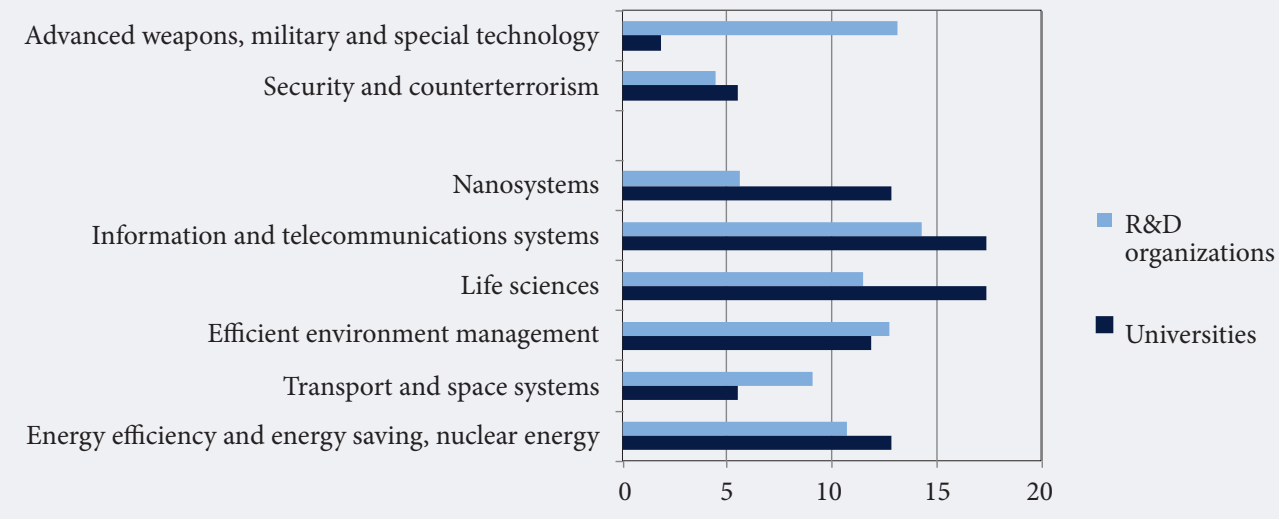

Source: IAAC, results of a sample survey of R\&D organisations, 2012.

- approved university strategies and programs as well as other documents published on their official websites;

- innovation development programs of defense industry companies cooperating with universities;

- presentations and reports by university and defense industry company officials at public events such as conferences, workshops, round table discussions, etc.

The main limitation of the applied research methodology was due to the fact that most of the data used to carry out the analysis originated at the very universities being analyzed. Since all of them had expressed their interest in stepping up defense-related R\&D and cooperation with the Ministry of Defense, a certain bias was inevitable: excessive optimism regarding their R\&D potential and competitiveness. However, since the documents of the industrial companies were also used along with the university sources, it allowed us to significantly reduce the partiality of the assessments.

It has turned out that almost a half of the surveyed universities (45\%), despite their interest in cooperating with the Ministry of Defense, were conducting no R\&D in national security- or defense-related S\&T fields. ${ }^{9}$ The ones that did have such experience in most cases specialized in designing military, specialand dual-purpose robotic systems and complexes (48\%), and less often conducted research in security and counterterrorism (29\%) and advanced weapons, military, and special technology (23\%).

Notably, the scope for cooperation between universities and the Ministry of Defense and defense industry companies was not limited to national security and defense-related priority S\&T areas as such. Therefore, in order to assess universities' potential to carry out relevant R\&D, a more extensive list must be use ${ }^{10}$.

The vast majority (97\%) of the surveyed universities did have groundwork results and competencies in the abovementioned areas (as a rule, in several). Twenty-five percent of them had experience in at least half of the research fields of interest to the Ministry of Defense. Most often universities conducted R\&D in such fields as materials, smart systems, control systems, expert and human-machine systems, and support technologies for robotic complexes (Figure 7)

Thus, despite their relatively modest involvement in R\&D in defense-related areas as such, universities actively conduct research in other areas of interest to the Ministry of Defense. Particularly important is the issue of the level of universities' R\&D, and of the solutions they propose. It should be noted that higher education organizations are well represented on Russian technology platforms, a significant share of which (more than 60\%) belong in subject areas important for the Ministry of Defense. Many universities (MSU, MSTU, MIPT, MEPhI, MAI, MISIS, TUSUR, FEFU, HSE, etc.) are key participants on relevant platforms, and in projects implemented for the state and various businesses. More than a half of the projects for developing high technologies implemented jointly by companies and universities with public support provided in the scope of the RF Government Regulation No. 218 of 09.04.2010 de facto had dual purposes, or at least were related to research areas important to the Ministry of Defense. Their results in most cases were assessed favorably, and not just on the basis of direct indicators such as the development and application of research-intensive products, but also in terms of building research competencies and skills required for cooperating with businesses [Dezhina, Simachev, 2013; Inconsult K, Ltd. et al., 2015].

\footnotetext{
9 Similar results were obtained in the framework of a questionnaire-based survey of 153 Russian universities conducted by the Scientific Research Institute - Federal Research Centre for Projects Evaluation and Consulting Services (SRI FRCEC): 49\% of the universities had no experience of carrying out national security and defense projects, nor have ever been proposed to do so; another $11 \%$ of the respondents, despite lacking relevant experience, still have been commissioned to conduct R\&D in these areas [Epishin et al., 2016].

${ }^{10}$ The corresponding list has been approved by the specialized subdivision of the Ministry of Defense of Russia as the main activities of the Center for Support of Initiative Development and Innovation. This list is open, moreover, one of the aims of its compilation is to inform the scientific community about the directions of research and innovation activities that correspond to the interests of the Ministry of Defense. Currently, the list includes 20 items presented in Figure 7.
} 
University does not conduct R\&D in any of the specified areas

Hydrodynamics Acoustics

Navigation

Powder, explosives, and rocket fuel components Technologies for detecting and identifying substances

Aero- and gas-dynamics

High-energy physics

Micro- and radioelectronics

Radiophysics

Mechanics

Communication systems

Geophysics, oceanology, atmospheric physics

Optics and quantum electronics

Energy systems

Medical technologies

Technologies to support existing robotic complexes

Expert systems, human-machine systems, and computers

Control systems
Smart systems

Materials

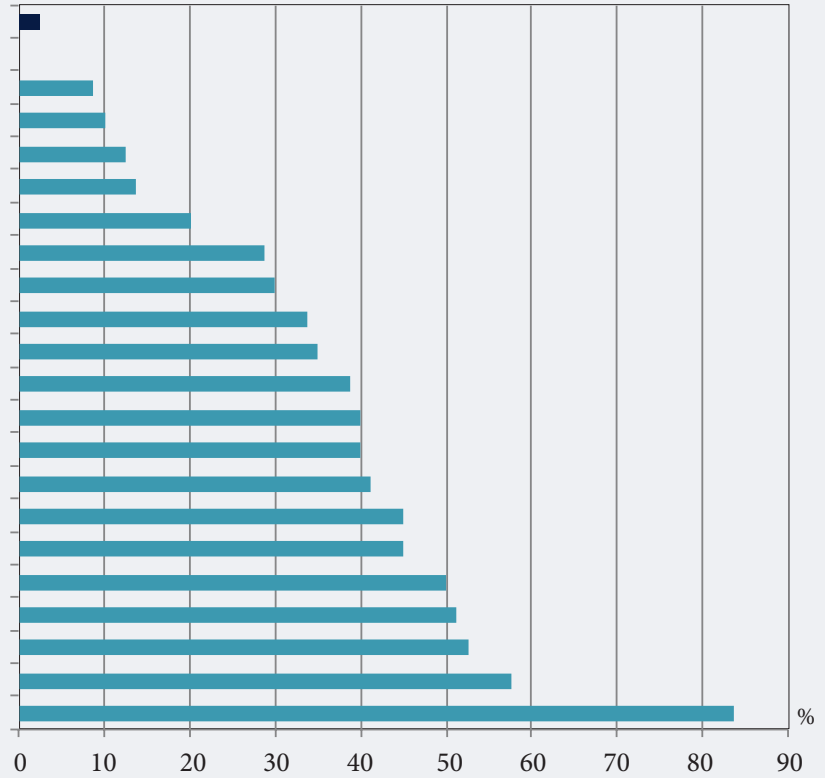

Source: IAC - results of the sample integrated assessment of universities, 2017.

About a half of the engineering centers established by universities have the necessary competencies and advanced equipment required for conducting defense-related or dual-purpose research, and practical experience executing defense industry companies' procurement orders. Businesses' demand for their services is also growing [Minobrnauki Rossii, Minpromtorg Rossii, 2017]. Universities actively cooperate with the Advanced Research Foundation, which provides support for high-risk R\&D aimed at obtaining breakthrough results in military hardware and technological development, the socioeconomic sphere, the development of innovative technologies, and the production of high-tech products for military, special, or dual purposes. ${ }^{11}$ Several leading universities, such as MIPT, TUSUR, SSAU, SUAI, VISU, and MAI, won the foundation's tenders for designing prototype technologies. The foundation established joint research laboratories with MSU, UNN, and SFedU. This gives ground to conclude that many of the universities willing to conduct defense-related, special- and dual-purpose R\&D do indeed have the required groundwork results and competences.

\section{Issues Associated with Universities'Participation in Defense-Related R\&D}

The current contradiction between universities' poor involvement in government-commissioned defenserelated $\mathrm{R} \& \mathrm{D}$ and their potential in this field is due to a number of issues with the state defense order's specific features and procedures for its placement as well as with certain characteristics of the universities and defense industry companies themselves.

First of all, most universities simply do not meet the numerous requirements set by the government for state defense order general contractors, such as:

- having a special bank account for making payments to other project participants;

- separate accounting for each contract signed in the framework scope of state defense order;

- providing financial securities for executing state defense order contracts;

- ensuring that the developed products meet special requirements.

In a number of cases, special licences are required (to design weapons and military equipment, ammunition, pyrotechnic products), as well as clearance to access state secrets. In addition, it is usually necessary to make and field-test prototypes, etc. Keeping all this in mind, few universities can act as general contractors executing state defense order. Only $20 \%$ of the universities included in our sample fully met the above requirements ${ }^{12}$.

Note that the model of a university's role as a state defense order principal contractor does not fit all universities, not by far. Only a few of the technological universities with access to relevant resources, competencies, and capabilities can meet the relevant standards. To others, executing specific orders by

\footnotetext{
${ }^{11}$ Due to the specific features of the foundation's activities it is frequently compared with DARPA [Eremenko, 2013; etc.].

${ }^{12}$ In the case of designing weapons, a lack of relevant licenses comes to the foreground. The aforementioned survey conducted by the SRI FRCEC revealed that only $7 \%$ of universities had such licenses (18\% of those who had worked with the Russian Ministry of Defense previously), and 3\% were in the process of acquiring them [Epishin et al., 2016].
} 
defense industry companies and their integrated structures seems to be the best format for taking part in defense-related R\&D. However, the level of universities' cooperation with the defense industry (and with industrial companies generally, for that matter) still remains low. According to a survey of Russian universities conducted by the IAC in $2015^{13}$, most of them do perform R\&D commissioned by industrial companies, but only for about a quarter of universities does the share of such R\&D projects exceeds $50 \%$ of the total.

The reasons of Russian universities' relatively poor cooperation with industrial enterprises has been repeatedly discussed in earlier works (see, e.g., [Simachev et al., 2014]), so we will concentrate on the factors and issues relevant to their cooperation with the defense industry. In most cases, defense-related $\mathrm{R} \& \mathrm{D}$ is commissioned by large public companies, holdings, and concerns. Such companies tend to have their own R\&D and design organizations or departments, which obviously have the best chance to obtain such work. Also, large companies specializing in defense (and in other industries as well) usually have an established system of production partnerships and contacts, first of all with leading R\&D organizations active in relevant research fields, so when they place orders they tend to go to their tried and true partners first [Simachev et al., 2014]. Most of the universities do not belong within the "established circle" of defense industry companies' production partners, so they by default have a smaller chance to winning procurement contracts, even if they do have advanced groundwork results and competencies in the R\&D and design fields.

In reality, mainly the universities that have close ties with defense industry companies (or are located in their vicinity) usually get orders from them. Accordingly, they can successively cooperate with these companies even in related areas such as:

- staff training;

- participation in joint civil research projects, including projects supported by the Russian Ministry of Education and Science;

- offering the services of universities' engineering centers and shared research equipment centers;

- cooperation in the framework of technology platforms or innovative territorial clusters.

In some cases, involving universities in executing public defense orders as co-contractors can be a logical extension of such cooperation.

Another serious barrier hindering universities' participation in defense-related R\&D is their image as exclusively educational organizations, not advanced research competency centers capable of professionally executing complex orders. This is due to the insufficient level of universities' activities in relevant R\&D areas, i.e., those matching state defense order. Note that it is not so much the actual R\&D performed by the universities as their public perception, i.e., coverage in media and the promotion of results. ${ }^{14}$ This is also evidence of insufficiently productive efforts that the government is making to step up universities' research and innovation potential.

At the same time, it would not be correct to say that the lack of companies' trust in universities as reliable performers of R\&D is exclusively due to the established stereotypes about academia and insufficient information about its potential. In particular, the results of surveys covering 400 state universities conducted by the HSE Institute for Statistical Studies and Economics of Knowledge indicate that fewer than $10 \%$ of state universities can be included in the group of education and research leaders capable of advancing science and integrating research and educational activities [Abankina et al., 2013]. Universities' inadequate focus on meeting consumers' needs, and the poor competitiveness of the solutions they offer come to the foreground [Simachev et al., 2014; Gershman et al., 2015]. Thus, the opportunities for promoting universities' participation in defense-related R\&D amount not only to stepping up their contacts and cooperation with defense industry companies, but also to improving their own internal arrangements, first of all bringing the R\&D areas they specialize in closer to the sector's actual demand.

\section{Conclusions and Recommendations}

Modern universities actively participate in research and innovation activities and show interest in security- and defense-related areas. In the US, UK, China, and other countries, they play a significant role in researching and developing special- and dual-purpose technologies. In Russia, the level of universities' R\&D activities generally remains quite low, which is one of the reasons of their poor involvement in defense-related R\&D. However, given the strong demand for such research funded through state defense order, this area of universities' R\&D activities seems to offer very good prospects.

We did not confine ourselves to a narrow interpretation of defense $R \& D$ as activities aimed at supporting national security and designing weapons, military, and special-purpose hardware, so having analyzed universities' results in a wide range of fields, we concluded that they have great potential for conducting such research.

However, universities' cooperation with industrial companies (including defense industry ones) remains rather weak, and in most cases, tends to be inertial and locally limited. Companies' (and their integrated structures') choice of R\&D contractors seems to be inclined towards their own R\&D departments or subsidiaries, or established partners, usually the sectoral research institutes and design bureaus. The low

\footnotetext{
${ }^{13}$ The survey was conducted in the autumn of 2015; university heads were asked to fill in specially designed questionnaires. 151 universities were included in the final sample.

${ }^{14}$ The lack of information about promising R\&D results as a factor hindering cooperation between science and industry is generally recognized by businesses and $\mathrm{R} \& \mathrm{D}$ organizations alike [Simachev et al., 2014]
} 
level of universities' participation in such work can be partially explained by companies' insufficient awareness of their actual potential, abilities, and achievements. Another reason is the sceptical attitude towards universities' ability to adequately execute complex R\&D orders, which is quite typical for businesses and not infrequently based on their previous experiences.

Promoting the defense industry's demand for university R\&D services would require a significant effort, first of all, by the universities themselves. They should work on their image, so that they would be perceived not as solely educational organizations but as research and development centers as well, and furthermore should advertise their relevant abilities, competencies, and achievements among potential customers. Conventional promotion techniques of this kind include publications, patenting, and training expert personnel. It is also important to participate in federal- and regional-level coordination and consulting bodies, expert councils, working groups, and other venues related to the defense industry. Establishing contacts and extending cooperation with potential customers via various communication and collaboration arrangements (such as technology platforms, clusters, etc.) also appears to be an effective tool.

Many universities will have to pay more attention to meeting companies' actual demands, and not just in terms of identifying relevant R\&D areas but also regarding arrangements and formats for the transfer and practical application of research results. The latter may require making certain organizational changes and applying innovative approaches such as setting up project teams comprised of staff from various university departments and the customers' representatives. Businesses often prefer to deal with R\&D providers not on the level of the whole organization but with specific staff members or divisions. Many universities see this as a problem hindering "normal" cooperation [Simachev et al., 2014]. Meanwhile, strengthening cooperation between industry and science requires that universities do not obstruct but promote the establishment of direct contacts between companies and research teams, both formal (laboratories, sections, etc.) and informal, as well as specific researchers and experts alike, for example, by publishing relevant information on the university website, in printed documents, presenting them at meetings, etc.

Cooperation between universities and defense industry companies can and should involve the active participation of the sectoral research institutes and design bureaus. Since the latter may see universities as competition, universities must offer the sectoral $\mathrm{R} \& \mathrm{D}$ organizations a mutually beneficial cooperation format.

Universities usually have a wider range of specialization areas than large research institutes do, so they can help the latter with conducting research, providing consulting and other services in less familiar fields. Given that universities have S\&T competencies in various areas, they can transfer advanced technologies between the military and civilian sectors more efficiently than the defense industry's own research institutes. Universities' research and innovation infrastructural facilities, created with public support, such as engineering, shared research equipment, technology transfer centers, etc., can serve as a key tool for strengthening the partnership between universities, academic institutes, and companies. The dynamic developments in a number of industries triggered by digitalization, human-machine and machine-tomachine communication, advanced manufacturing technologies, etc., have opened new opportunities for such cooperation. In a situation of major technological transformations, leading universities can not only provide local services to companies, but act as catalysts of change by offering companies advanced technologies and solutions in the framework of "search network" especially designed for these purposes. No less important is the position of the other side, i.e., the businesses. Previous studies show that strengthening universities' and research organizations' partnerships with companies is hindered by the latter's insufficient openness to innovation. Thus, stepping up this cooperation would involve promoting not only the supply of, but also demand for innovations.

In the aforementioned situation, the role of the state becomes crucial: it must create favorable conditions and incentives for effective cooperation between universities and industry [Etzkowitz, Leydesdorff, 2000; Tether, Tajar, 2008]. In particular, information exchanges between them in a mutually beneficial format should be encouraged (at least on the basis of the existing interactive information systems). As to businesses' low level of interest in innovation, there is no universal recipe for overcoming this hurdle quickly and irreversibly. Practice shows that administrative and directive steps do not work very well in this regard. Certain tax incentives, changes of technological regulations and standards encouraging the application of new products, technologies, and equipment and abandoning old ones seem to have a significant positive effect on the level of innovativeness for the whole industry or its specific segments (at least in terms of the number of enterprises involved) [Ivanov et al., 2012]. Providing financial support makes the largest contribution to promoting separate Russian companies' innovation activities [Simachev et al., 2017]. Therefore, it is important to extend the practices of public participation in funding the research universities conduct for businesses, and it is also critical implement joint innovative projects. As was noted, it encourages the establishment of partnerships between universities and defense industry companies in the military and civil sectors alike. Implementing civil and military projects in parallel with one another could lead to the convergence of and mutual penetration in relevant subject areas, help obtain breakthrough results, and propose new, promising scientific and technological areas.

S\&T development priorities may play a major role in encouraging universities to conduct defense-related and dual-purpose R\&D. Identifying relevant focus areas for cooperation between universities, research organizations, companies, and the state would help concentrate resources and efforts in the R\&D areas that would make the greatest contribution to national security. As for universities willing to step up their cooperation with the defense industry, such priorities may serve as a foundation not only for defining their research agendas but also for developing and updating their curricula. 
Involving all key actors in priority-setting would allow to take into account their positions and interests, which is critically important for their accepting the priorities as guidelines to be followed, and for promoting communication between the involved parties. This would require coming up with a unified priority-setting methodology based on the following principles:

- focus on accomplishing major national security objectives;

- medium-term planning horizon;

- taking into account national competitive advantages with a focus on their implementation;

- assessing feasibility ( the availability of the required resources, S\&T groundwork results, etc.);

- planning for the application of specific STI policy tools.

A focus on ensuring national security does not mean that all priority areas and technologies selected for development should be of a distinctly military nature. The convergence of civil and military technologies can provide a major boost for the advancement of science, eliminate the duplication of research areas, and help concentrate resources on accomplishing the most important objectives.

Focus areas for cooperation between universities, research organizations, companies, and the state in the field of defense should match existing national S\&T priorities, and fit into the long-term technology foresight system. Particular attention should be paid to relevant implementation mechanisms, specifically to ensure their integration with existing STI and industrial policy tools. The new system of priorities must be flexible, capable of quickly adjusting to emerging developments in S\&T, in the defense industry, and in the overall industrial sector. The continuous monitoring of priority implementation would help assess their contribution to accomplishing national security objectives and help to adjust their content and fine-tune implementation mechanisms. The list of priorities should be regularly updated in line with changing S\&T development trends.

In conclusion, we would like to stress that the current situation with the research and innovation activities of Russian universities is not unique. Problems with cooperation between universities' research divisions and industrial companies, which have been analyzed for the Russian context, engendered by universities' insufficient entrepreneurial activity, predominantly "educational" image, competition from other organizations that create knowledge and develop technologies, and businesses' poor interest in innovation, are typical for other countries as well [Davies, 2001; Deiaco et al., 2008; Smith et al., 2011; Foss, Gibson, 2015; Oosterbeek et al., 2010; Stensaker, Benner, 2013]. Accordingly, the proposed recommendations and conclusions apply not only to Russia but also to any country facing the same issues with strengthening universities' research and their cooperation with businesses. Still, national specifics of universities' cooperation with defense industry companies do deserve special attention.

This paper certainly has not covered all relevant aspects of universities' participation in military, specialand dual-purpose R\&D. The issue of universities' having the necessary groundwork results, and their competitiveness in the area was analyzed only partially. The effects of the various forms of government support on the scale and productivity of universities' military, special- and dual-purpose R\&D and on the effectiveness of their cooperation with defense industry companies deserve a special study. This also applies to universities' partnerships with academic and sectoral research organizations, their role in the inter-sectoral transfer of advanced technologies, and the necessary changes of universities' organizational structure to support successful cooperation with businesses, etc. All these issues seem to serve as promising topics for future research.

The paper is based on the results of the project "A study of the Russian Ministry of Defense's need to involve higher education and research organizations supervised by the Russian Ministry of Education and Science in executing state defense order, and of higher education and research organisations' potential to meet such needs. Setting scientific and technological priorities for cooperation between the Russian Ministry of Education and Science and the Russian Ministry of Defense" (unique project identifier RFMEFI57316X0015). The project is being implemented by the Interdepartmental Analytical Center, Inc. and funded by a subsidy provided by the Russian Ministry of Education and Science. The authors gratefully acknowledge Yuri Simachev's help with finalizing this paper, and guarantee that no information provided here contains any state secrets.

\section{References}

Abankina I., Aleskerov F., Belousova V., Gokhberg L., Zinkovsky K., Kiselgof S., Shvydun S. (2013) Tipologiya i analiz nauchno-obrazovatel'noy rezul'tativnosti rossiyskikh vuzov [A Typology and Analysis of Russian Universities' Performance in Education and Research]. Foresight-Russia, vol. 7, no 3, pp. 48-63 (in Russian).

Caloghirou Y., Kastelli I., Tsakanikas A. (2004) Internal capabilities and external knowledge sources: complements or substitutes for innovative performance? Technovation, vol. 24, no 1, pp. 29-39.

Clark B. (1998) Creating Entrepreneurial Universities: Organizational Pathways of Transformation, Oxford: Pergamon Press.

Cornell University, INSEAD, WIPO (2017) The Global Innovation Index 2017: Innovation Feeding the World. Available at: http://www.wipo.int/edocs/pubdocs/en/wipo_pub_gii_2017.pdf, accessed 15.09.2017.

D’Este P., Patel P. (2007) University-industry linkages in the UK: What are the factors underlying the variety of interactions with industry? Research Policy, vol. 36, no 9, pp. 1295-1313.

DARPA (2016) Innovation at DARPA, Arlington, VI: DARPA. Available at: http://www.darpa.mil/attachments/ DARPA_Innovation_2016.pdf 2 accessed 15.09.2017.

Davies J. (2001) The Emergence of Entrepreneurial Cultures in European Universities. Higher Education Management, vol. 13 , no 2, pp. 25-43.

Deiaco E., Holmén M., McKelvey M. (2008) What does it mean conceptually that universities compete? (CESIS Working Paper no 139), Stockholm: The Royal Institute of Technology. 
Dezhina I., Kiseleva V. (2007) “Troinaya spiral”" v innovatsionnoi sisteme Rossii ["Triple Helix" in Russian Innovation System]. Voprosy Ekonomiki, no 12, pp. 123-135 (in Russian).

Dezhina I., Simachev Yu. (2013) Svyazannye granty dlya stimulirovaniya partnerstva kompanii i universitetov v innovatsionnoi sfere: startovye effekty primeneniya v Rossii [Matching Grants for Stimulating Partnerships between Companies and Universities in Innovation Area: Initial Effects in Russia]. Zhurnal Novoi ekonomicheskoi assotsiatsii [Journal of the New Economic Association], no 3, pp. 99-122 (in Russian).

Epishin K., Zernykov D., Komarov I. (2016) Rezul'taty anketirovaniya vuzov na predmet nauchno-issledovatel'skikh i opytno-konstruktorskikh razrabotok, provodimykh $\mathrm{v}$ interesakh natsional'noi bezopasnosti [Results of survey of the universities for research and development carried out in the interests of national security]. Innovatika $i$ ekspertiza: nauchnye trudy [Innovatics and Expert Examination: The collection of scientific works], no 1 (16), pp. 230-237 (in Russian).

Eremenko V. (2013) Fond perspektivnykh issledovanii kak instrument modernizatsii oboronno-promyshlennogo kompleksa [Foundation for Advanced Studies as an Instrument for Modernizing the Defense Industrial Complex]. Izobretatelstvo [Invention], vol. 13, no 8, pp. 13-22 (in Russian).

Etzkowitz H. (2003) Innovation in innovation: The Triple Helix of university-industry-government relation. Social Science Information, vol. 42, no 3, pp. 293-337.

Etzkowitz H., Leydesdorff L. (1995) The Triple Helix: University-industry-government relations. A laboratory for knowledge based economic development. EASST Review. European Society for the Study of Science \& Technology, vol. 14, no 1, pp. 14-19.

Etzkowitz H., Leydesdorff L. (2000) The Dynamic of Innovations: From National System and "Mode 2" to a Triple Helix of University-Industry-Government Relations. Research Policy, vol. 29, no 1, pp. 109-129.

Etzkowitz H., Webster A., Gebhardt C., Cantisano Terra B.R. (2000) The Future of the University and the University of the Future: Evolution of Ivory Tower to Entrepreneurial Paradigm. Research Policy, vol. 29, no 2, pp. 313-330.

Foss L., Gibson D.V. (eds.) (2015) The Entrepreneurial University - Context and Institutional Change, New York: Routledge.

Frolov A. (2016) Ispolnenie oboronnogo zakaza Rossii v 2015 godu [Execution of the defense order of Russia in 2015]. Eksport vooruzhenii [Export of weapons], no 3, pp. 16-27 (in Russian).

Gershman M., Zinina T., Romanov M., Rudnik P., Senchenya G., Shadrin A. (2015) Programmy innovatsionnogo razvitiya kompanii s gosudarstvennym uchastiem: promezhutochnye itogi i prioritety [Innovation Development Programmes of Russian State-Owned Companies: Interim Results and Priorities] (eds. L. Gokhberg, A. Klepach, P. Rudnik, G. Senchenya, O. Fomichev, A. Shadrin), Moscow: HSE (in Russian).

Gertner J. (2012) The Idea Factory: Bell Labs and the Great Age of American Innovation, New York: Penguin Group.

Glänzel W., Schlemmer B. (2007) National research profiles in a changing Europe (1983-2003). An exploratory study of sectoral characteristics in the Triple Helix. Scientometrics, vol. 70, no 2, pp. 267-275.

Gokhberg L., Kuznetsova T. (2011) S\&T and Innovation in Russia: Key Challenges of the Post-Crisis Period. Journal of East-West Business, vol. 17, no 2-3, pp. 73-89.

Gokhberg L., Kuznetsova T., Zaichenko S. (2009) Towards a New Role of Universities in Russia: Prospects and Limitations. Science and Public Policy, vol. 36, no 2, pp. 121-126.

Henderson R., Jaffe A., Trajtenberg M. (1998) Universities as a source of commercial technology: A detailed analysis of university patenting. Review of Economic and Statistics, vol. 80, no 1, pp. 119-127.

Hirschi C. (2013) Die Organisation von Innovation - uber die Geschichte einer Obsession. Angewandte Chemie, vol. 125 , no 52 , pp. $14118-14122$.

HSE (2008) Indikatory nauki: 2008 (statisticheskii sbornik) [Science and Technology Indicators in the Russian Federation: 2008 (Data Book)] (eds. L. Gokhberg, A. Kevesh, Ya. Kouzminov, Z. Ryzhikova, V. Fridlyanov), Moscow: HSE (in Russian).

HSE (2009) Indikatory nauki: 2009 (statisticheskii sbornik) [Science and Technology Indicators in the Russian Federation: 2009 (Data Book)] (eds. L. Gokhberg, A. Kevesh, Ya. Kouzminov, Z. Ryzhikova, V. Fridlyanova), Moscow: HSE (in Russian).

HSE (2010) Indikatory nauki: 2010 (statisticheskii sbornik) [Science and Technology Indicators in the Russian Federation: 2010 (Data Book)] (eds. L. Gokhberg, Ya. Kuozminov, K. Laikam, A. Naumov, V. Fridlyanov), Moscow: HSE (in Russian).

HSE (2011) Indikatory nauki: 2011 (statisticheskii sbornik) [Science and Technology Indicators in the Russian Federation: 2011 (Data Book)] (eds. L. Gokhberg, Ya. Kouzminov, K. Laikam, A. Naumov), Moscow: HSE (in Russian).

HSE (2012) Indikatory nauki: 2012 (statisticheskii sbornik) [Science and Technology Indicators in the Russian Federation: 2012 (Data Book)] (eds. A. Anopchenko, L. Gokhberg, Ya. Kouzminov, K. Laikam), Moscow: HSE (in Russian).

HSE (2013) Indikatory nauki: 2013 (statisticheskii sbornik) [Science and Technology Indicators in the Russian Federation: 2013 (Data Book)] (eds. L. Gokhberg, Ya. Kouzminov, K. Laikam, I. Fedyukin), Moscow: HSE (in Russian).

HSE (2014) Indikatory nauki: 2014 (statisticheskii sbornik) [Science and Technology Indicators in the Russian Federation: 2014 (Data Book)] (ed. L. Gokhberga, Ya. Kouzminov, K. Laikam, S. Salikhov), Moscow: HSE (in Russian).

HSE (2015) Indikatory nauki: 2015 (statisticheskii sbornik) [Science and Technology Indicators in the Russian Federation: 2015 (Data Book)] (eds. L. Gokhberg, Ya. Kouzminov, K. Laikam, S. Matveev), Moscow: HSE (in Russian).

HSE (2016) Indikatory nauki: 2016 (statisticheskii sbornik) [Science and Technology Indicators in the Russian Federation: 2016 (Data Book)] (eds. L. Gokhberg, Ya. Kouzminov, K. Laikam, S. Salikhov), Moscow: HSE (in Russian).

HSE (2017) Indikatory nauki: 2017 (statisticheskii sbornik) [Science and Technology Indicators in the Russian Federation: 2017 (Data Book)] (eds. L. Gokhberg, Ya. Kouzminov, K. Laikam, S. Matveev), Moscow: HSE (in Russian).

InConsult K, IAC, VICor, RFSTD (2015) Ot idei k real'nosti. Katalog proektov, realizuemykh v ramkakh Postanovleniya Pravitel'stva Rossiiskoi Federatsii ot 9 aprelya 2010 goda № 218 [From idea to reality. The catalog of projects implemented under the Russian Government Resolution No. 218 of April 9, 2010]. InConsult K Ltd., IAC, VICor, RFSTD. Available at: http://p218.ru/images/kwinners/cat218.pdf, accessed 07.08.2017 (in Russian).

Ivanov D., Kuzyk M., Simachev Y. (2012) Stimulirovanie innovatsionnoy deyatel'nosti rossiyskikh proizvodstvennykh kompaniy: novye vozmozhnosti i ogranicheniya [Fostering Innovation Performance of Russian Manufacturing Enterprises: New Opportunities and Limitations]. Foresight-Russia, vol. 6, no 2, pp. 18-41 (in Russian). 
Kuzyk M., Simachev Yu. (2013) Rossiiskaya politika po stimulirovaniyu innovatsii: evolyutsiya, dostizheniya, problemy i uroki [Russia's Innovation Promotion Policies: Their Evolution, Achievements, Problems and Lessons]. Rossiiskaya ekonomika v 2012 godu. Tendentsii i perspektivy [Russian Economy in 2012. Trends and Prospects], issue 34, Moscow: Gaidar Institute, pp. 521-571 (in Russian).

Meyer-Krahmer F., Schmoch U. (1998) Science-based technologies: University-industry interactions in four fields. Research Policy, vol. 27, no 8, pp. 835-851.

Minobrnauki Rossii, Minpromtorg Rossii (2017) Razvitie inzhiniringovykh tsentrov na baze obrazovatel'nykh organizatsii vysshego obrazovaniya. Informatsionno-analiticheskii sbornik [Development of engineering centers on the basis of educational organizations of higher education. Informational and analytical collection], Moscow: "ProfKonsaltKompani" Ltd. (in Russian)

Molas-Gallart J., Sinclair T. (1999) From technology generation to technology transfer: The concept and reality of the "Dual-Use Technology Centres". Technovation, vol. 19, no 11, pp. 661-671.

Oosterbeek H., van Praag M., Ijsselstein A. (2010) The impact of entrepreneurship education on entrepreneurship skills and motivation. European Economic Review, vol. 54, pp. 442-454.

Pankova V. (2016) Voennaya ekonomika, innovatsii, bezopasnost' [Military Economics, Innovation, and Security], Moscow: IMEMO (in Russian).

Perkmann M., Walsh K. (2007) University-industry relationships and open innovation: Towards a research agenda. International Journal of Management Reviews, vol. 9, no 4, pp. 259-280.

Popova E. (2010) Organizatsionnaya struktura i mekhanizmy funktsionirovaniya upravleniya perspektivnykh issledovatel'skikh proektov Ministerstva oborony SShA (DARPA). Vozmozhnoe ispol'zovanie opyta DARPA dlya Rossii [Organizational structure and mechanisms for the functioning of the Office for Advanced Research Projects at the US Department of Defense (DARPA). Evaluating possibilities of applying DARPA experience to Russia]. Innovatsii [Innovations], no 11, pp. 5-10 (in Russian).

Razak A.A., White G.R.T. (2015) The Triple Helix Model for Innovation: A holistic exploration of barriers and enablers. International Journal of Business Performance and Supply Chain Modelling, vol. 7, no 3, pp. 278-291.

Siegel D., Waldman D., Atwater L., Link A. (2003) Commercial knowledge transfers from universities to firms: Improving the effectiveness of university-industry collaboration. The Journal of High Technology Management Research, vol. 14, no 1, pp. 111-133.

Simachev Y., Kuzyk M., Feygina V. (2015) Interaction between Business and Research Organizations in the Sphere of Innovations: The Russian Experience in Promoting Cooperation (RANEPA Working Paper 431503), Moscow: Russian Presidential Academy of National Economy and Public Administration. Available at: ftp://w82.ranepa.ru/ rnp/ppaper/431503.pdf, accessed 15.09.2017.

Simachev Y., Kuzyk M., Zudin N. (2016) Import Dependence and Its Substitution in the Russian Manufacturing: Business Viewpoint. Foresight and STI Governance, vol. 10, no 4, pp. 25-45.

Simachev Yu., Kuzyk M., Feigina V. (2014) Vzaimodeistvie rossiiskikh kompanii i issledovatel'skikh organizatsii v provedenii NIOKR: tretii ne lishnii? [R\&D Cooperation between Russian Firms and Research Organizations: Is There a Need for State Assistance?]. Voprosy Ekonomiki, no 7, pp. 4-34 (in Russian).

Simachev Yu., Kuzyk M., Zudin N. (2017) Rezul'taty nalogovoi i finansovoi podderzhki rossiiskikh kompanii: proverka na dopolnitel'nost' [The Impact of Public Funding and Tax Incentives on Russian Firms: Additionality Effects Evaluation]. Zhurnal Novoi ekonomicheskoi assotsiatsii [Journal of the New Economic Association], no 2, pp. 59-93 (in Russian).

Smith A., Courvisanos J., Tuck J., McEachern S. (2011) Building Innovation Capacity: The Role of Human Capital Formation in Enterprises - A Review of the Literature, Adelaide (AU): National Centre for Vocational Education Research (NCVER). Available at: http://files.eric.ed.gov/fulltext/ED517803.pdf, accessed 14.11.2017.

Stensaker B., Benner M. (2013) Doomed to be Entrepreneurial: External and Internal Factors Conditioning the Strategic Development of 'New' Universities. Minerva: A Review of Science, Learning and Policy, vol. 51, no 4, pp. 399-416.

Tether B. S., Tajar A. (2008) Beyond industry-university links: Sourcing knowledge for innovation from consultants, private research organisations and the public science-base. Research Policy, vol. 37, no 6-7, pp. 1079-1095.

WEF (2016) The Global Competitiveness Report 2016-2017 (ed. K. Schwab), Geneva: World Economic Forum. 


\section{ABOUT THE JOURNAL}

Foresight and STI Governance (formerly Foresight-Russia) is an open access journal established by the National Research University Higher School of Economics (HSE) and administered by the HSE Institute for Statistical Studies and Economics of Knowledge (ISSEK), located in Moscow, Russia. The mission of the journal is to support the creation of Foresight culture through the dissemination of the best national and international practices of future-oriented innovation development. It also provides a framework for discussing S\&T trends and policies.

\section{TOPICAL COVERAGE:}

- Foresight methodologies

- Results of Foresight studies

- Long-term priorities for social, economic and S\&T development

- S\&T and innovation trends and indicators

- S\&T and innovation policies

- Strategic programmes of innovation development at national, regional, sectoral and corporate levels

- State-of-the-art methods and best practices of S\&T analysis and Foresight

\section{TARGET AUDIENCE:}

Research scholars, university professors, policy-makers, businessmen, expert community, post-graduates, undergraduates and others who are interested in S\&T and innovation analyses, Foresight and policy issues.

The topical coverage of the journal makes it a unique Russian language title in its field. Foresight and STI Governance is published quarterly and distributed in Russia and abroad.

\section{INDEXING AND ABSTRACTING}

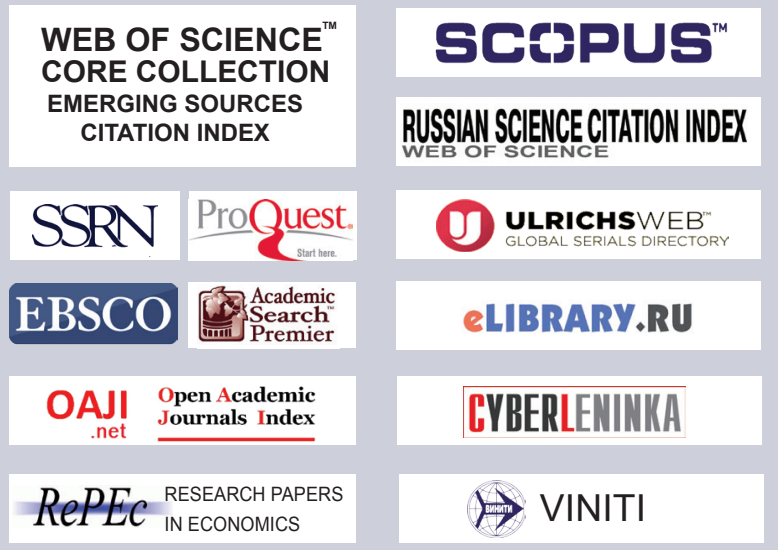

Scopus SJR Ranking - Q2 (since 2016)

Category: Business, Management and Accounting (miscellaneous) 
Before submitting your article, please prepare your manuscript using the following guidelines:

Articles should be topical and original, should outline tasks (issues), describe the key results of the author's research and his/her conclusions;

Manuscripts are to be submitted via e-mail: foresight-journal@hse.ru

\title{
Format
}

All files should be submitted as a Word document.

The text should be in Times New Roman 14 pt, 1.5 spaced and fit to the width, all margins should be $20 \mathrm{~mm}$.

\section{Article Length}

Articles should be between 20000 and 60000 characters (incl. spaces). Optimal size is 40000 characters.

\section{Article Title}

To be submitted in native language and English. A title of not more than eight words should be provided.

\section{Author Details (in English and native language)}

Details should be supplied on the Article Title Page, including:

- Full name of each author

- Position, rank, academic degree

- Affiliation of each author, at the time the research was completed

- Full postal address of the affiliation

- E-mail address of each author

\author{
Abstract \\ - Purpose (mandatory) \\ - Design/methodology/approach (mandatory) \\ - Findings (mandatory) \\ - Research limitations/implications (if applicable) \\ - Practical implications (if applicable) \\ - Social implications (if applicable) \\ - Originality/value (mandatory)
}

An abstract should be: informative (no general words), original, relevant (reflects your paper's key content and research findings); structured (follows the logics of the results presented in the paper), concise (between 250 and 300 words).

It is appropriate to describe the research methods/methodology if they are original or of interest for this particular research. For papers concerned with experimental work describe your data sources and data processing techniques. Describe your results as precisely and informatively as possible. Include your key theoretical and experimental results, factual information, and any interconnections and patterns shown. Give special priority in your abstract to new results and data with long-term impact, important discoveries and verified findings that contradict previous theories as well as data that you think have practical value.

Conclusions could be associated with recommendations, estimates, suggestions, and hypotheses described in the paper. Information contained in the title should not be dublicated in the abstract. Try to avoid unnecessary introductory phrases (e.g. 'the author of the paper considers...').

Use language typical of research and technical documents to compile your abstract and avoid complex grammatical constructions.

The text of the abstract should include the key words of the paper.

\section{Keywords}

Please provide up to 10 keywords on the Article Title Page, which encapsulate the principal topics of the paper.

\section{Headings}

Headings must be concise, with a clear indication of the distinction between the hierarchy of headings.

\section{Figures}

All figures should be of high quality, legible, and numbered consecutively with arabic numerals. All figures (charts, diagrams, line drawings, web pages/screenshots, and photographic images) should be submitted in electronic form pref erably in color as separate files, that match the following parameters:

Photo images - JPEG or TIFF format. Minimum resolution 300 dpi, image size not less than 1000x1000 pix

Charts, diagrams, line drawings- EXCEL or EPS format 

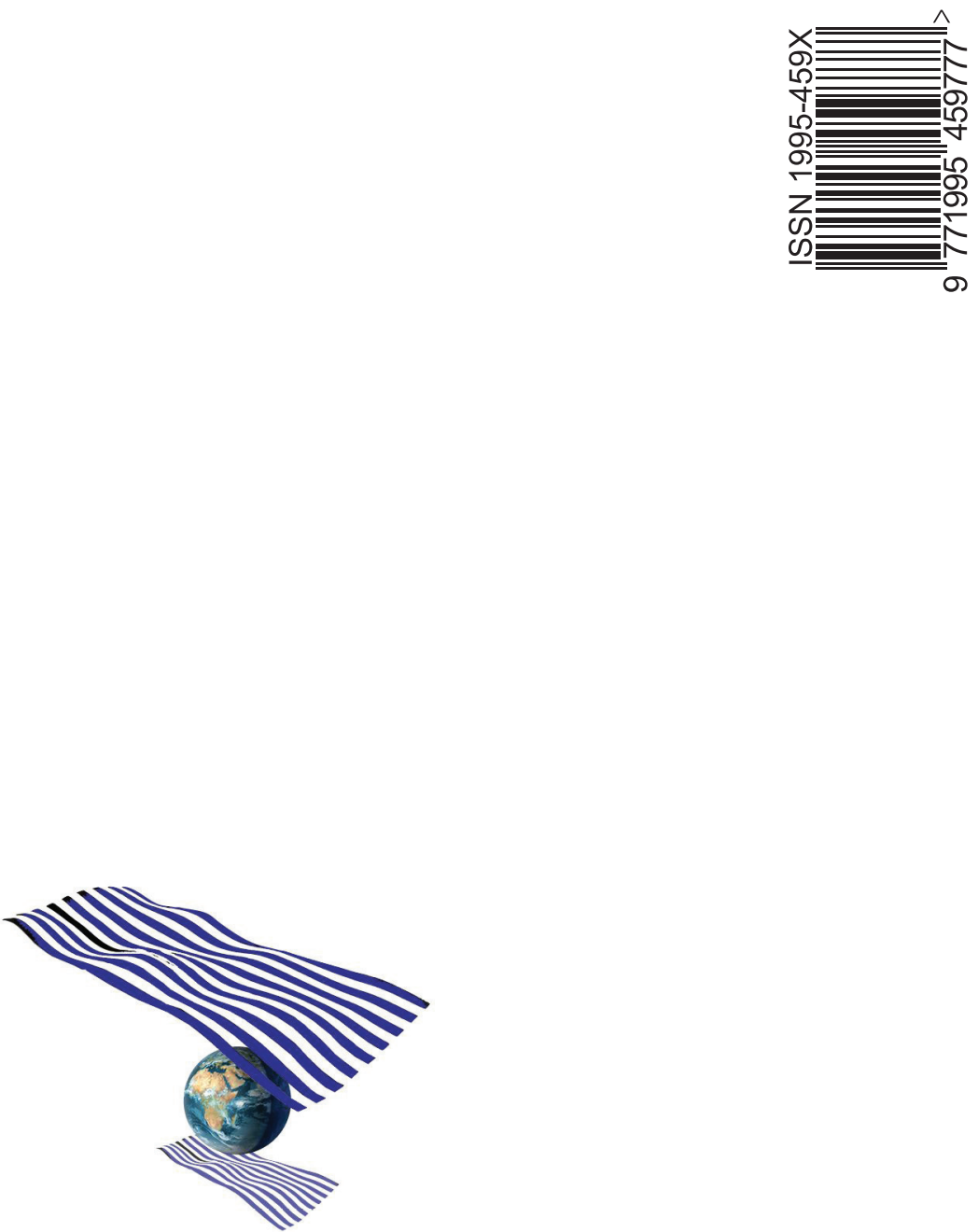

Website

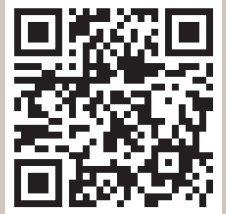

Co Download on the

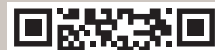

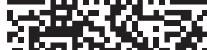

sars

$4 x^{2} 5$

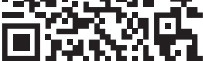

GETION

Google Play

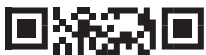
Gar $+2$ Hs

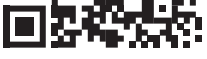

